III Nordiska

ministerrådet

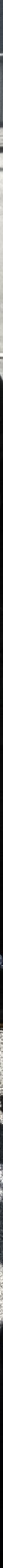




\section{Styrning av arbetsmarknaden i Norden}

Komparativ studie av arbetsmarknadspolitikens styrning i Norden

Kullander, Mats

Tönnes Lönnroos, Lisa

Oxford Research

TemaNord 2016:556 


\section{Styrning av arbetsmarknaden i Norden}

Komparativ studie av arbetsmarknadspolitikens styrning i Norden

Kullander, Mats

Tönnes Lönnroos, Lisa

Oxford Research

ISBN 978-92-893-4763-1 (PRINT)

ISBN 978-92-893-4764-8 (PDF)

ISBN 978-92-893-4765-5 (EPUB)

http://dx.doi.org/10.6027/TN2016-556

TemaNord 2016:556

ISSN $0908-6692$

Standard: PDF/UA-1

ISO 14289-1

C Nordiska ministerrådet 2016

Layout: Hanne Lebech

Tryck: 120

Print: Rosendahls-Schultz Grafisk

Printed in Denmark

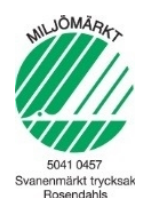

Denna rapport är utgiven med finansiellt stöd från Nordiska ministerrådet. Innehållet i rapporten avspeglar inte nödvändigtvis Nordiska ministerrådets synpunkter, åsikter eller rekommendationer

\section{Det nordiska samarbetet}

Det nordiska samarbetet är ett av världens mest omfattande regionala samarbeten. Det omfattar Danmark, Finland, Island, Norge och Sverige samt Färöarna, Grönland och Åland.

Det nordiska samarbetet är politiskt, ekonomiskt och kulturellt förankrat och en viktig del av europeiskt och internationellt samarbete. Den nordiska gemenskapen arbetar för ett starkt Norden i ett starkt Europa.

Det nordiska samarbetet ska stärka nordiska och regionala intressen och värderingar i en global omvärld. Gemensamma värderingar länderna emellan bidrar till att stärka Nordens ställning som en av världens mest innovativa och konkurrenskraftiga regioner. 


\section{Innehåll}

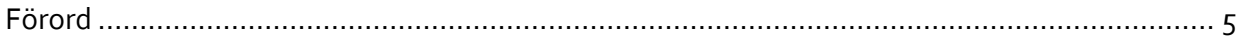

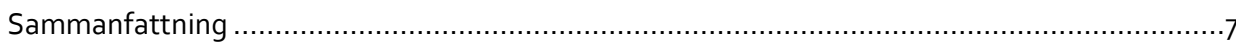

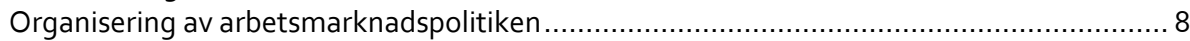

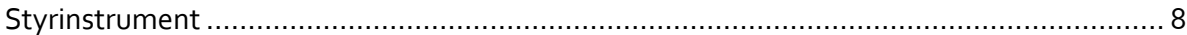

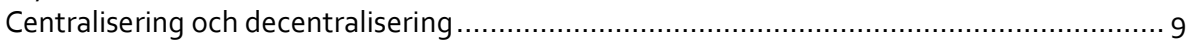

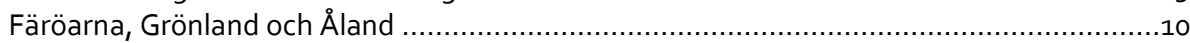

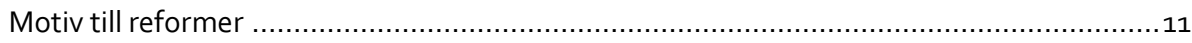

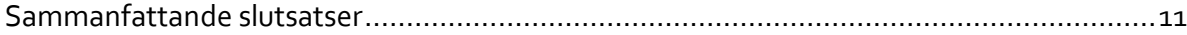

Rekommendationer - Vad kan länderna lära av varandra? ......................................14

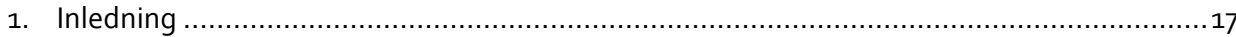

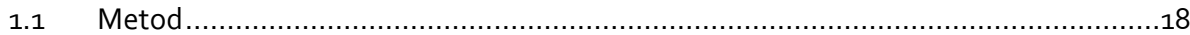

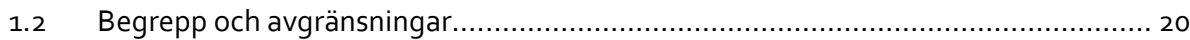

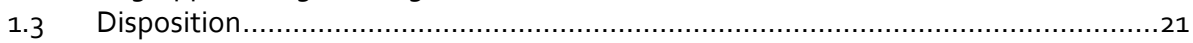

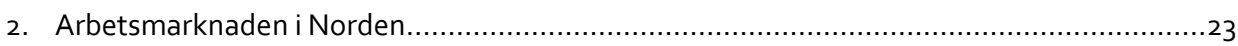

2.1 Sysselsättningsgrad och arbetslöshet.........................................................23

2.2 Offentliga utgifter för arbetsmarknadspolitik ............................................. 34

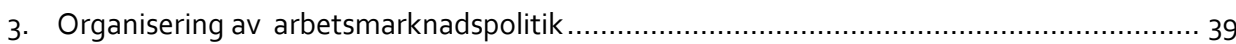

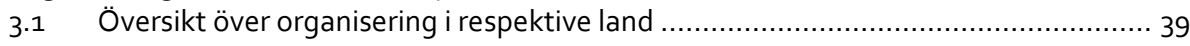

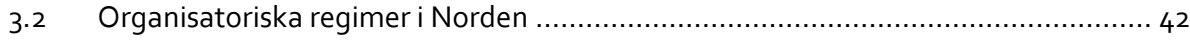

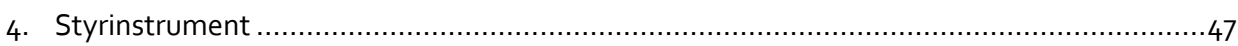

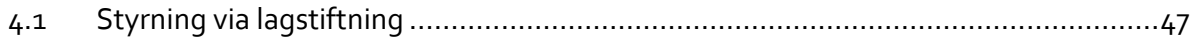

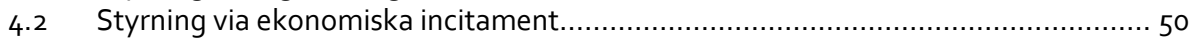

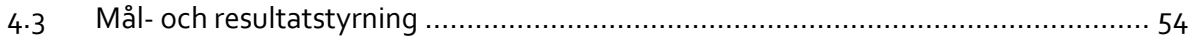

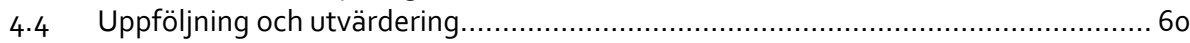

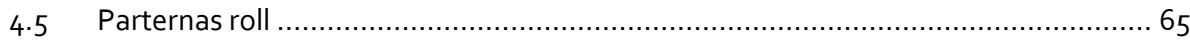

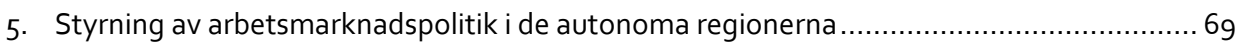

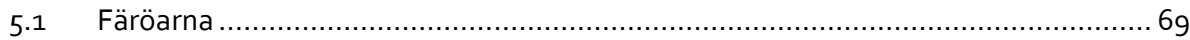

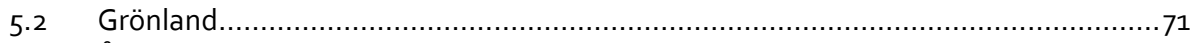

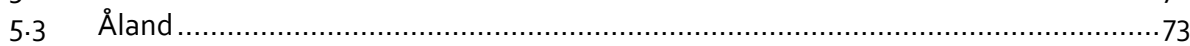

6. Centralisering och decentralisering i Norden .......................................................... 75

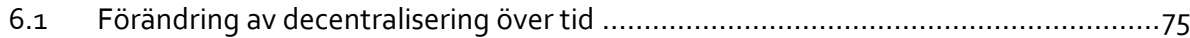

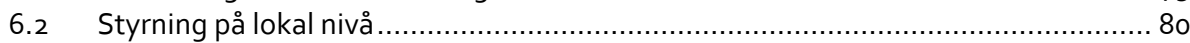

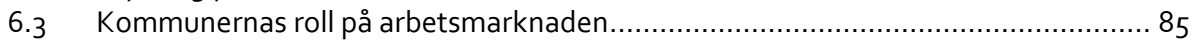

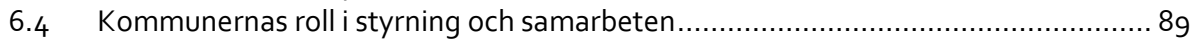

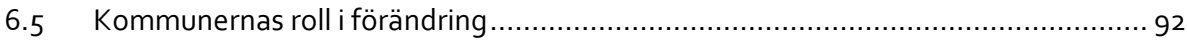

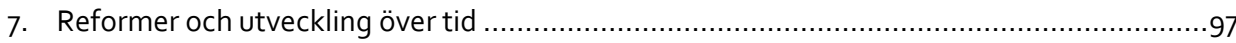

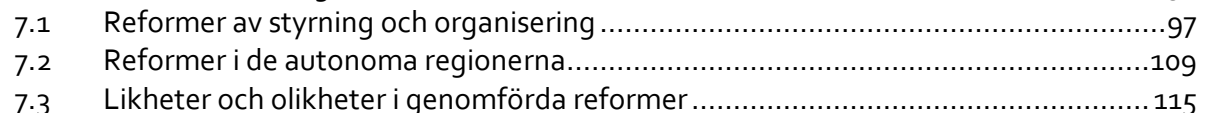




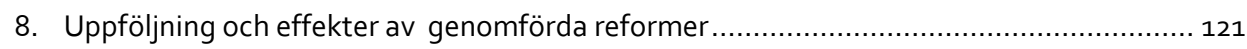

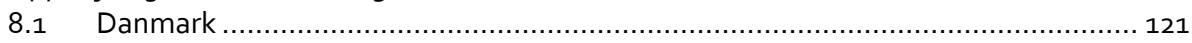

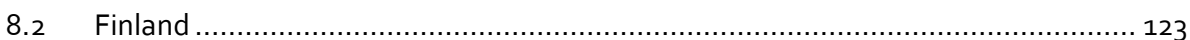

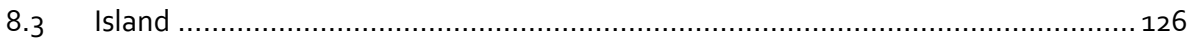

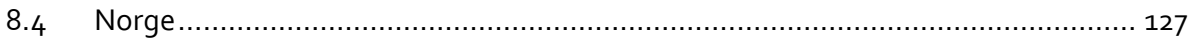

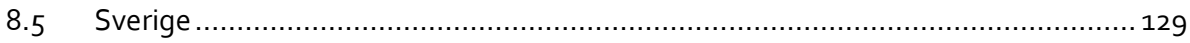

9. Slutsatser - effekter av reformer och skillnader i styrning ......................................133

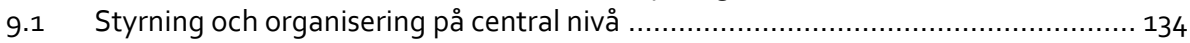

9.2 Decentralisering och kommunernas roll ....................................................... 138

9.3 Rekommendationer - Vad kan länderna lära av varandra? ............................... 140

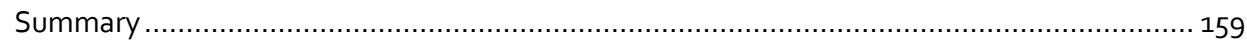

The organisation of labour market policies ...................................................... 160

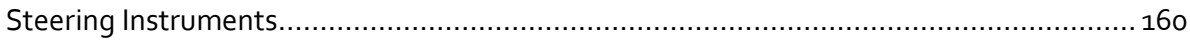

Centralisation and decentralisation ................................................................. 161

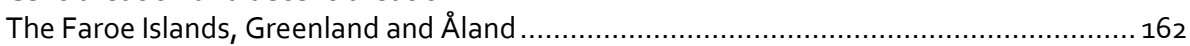

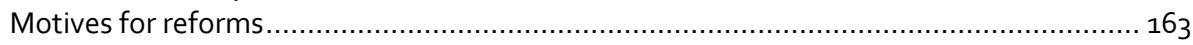

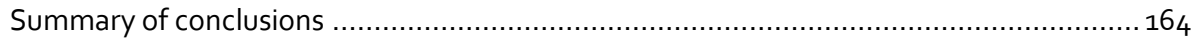

Recommendations: What can the countries learn from one another? ............................ 166

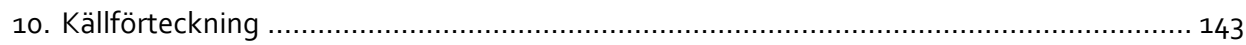

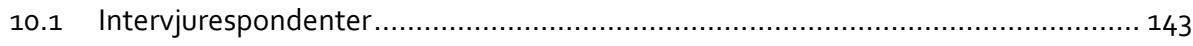

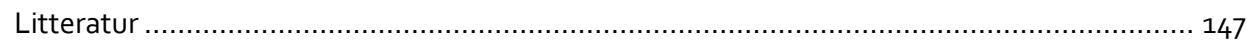

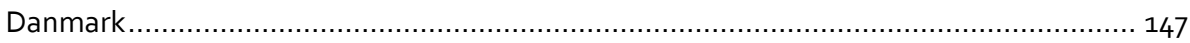

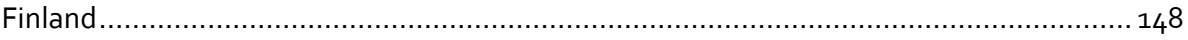

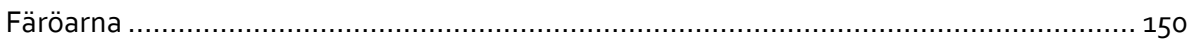

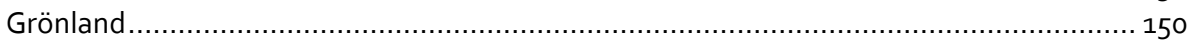

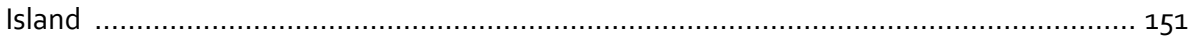

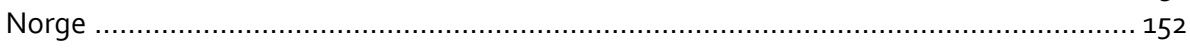

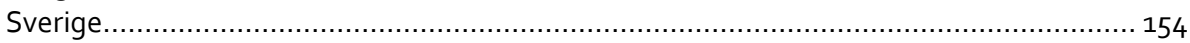

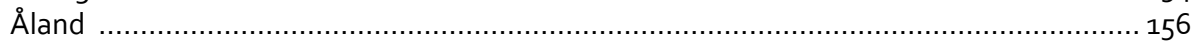

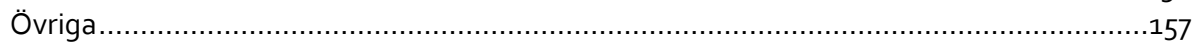

Bilaga 1: Arbetsmarknads-politikens verktygslåda .................................................. 169

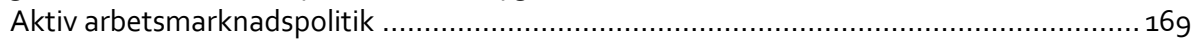

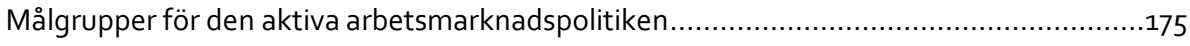

Ersättningssystem (passiv arbetsmarknadspolitik) ................................................ 182

Bilaga 2 Deltidsarbete och tidsbegränsade anställningar ........................................... 191 


\section{Förord}

I internationella diskussioner framhålls ofta den nordiska modellen som något som andra länder kan ta lärdom av. Det gäller kanske inte minst på det arbetsmarknadspolitiska området. De nordiska länderna har sedan länge haft omfattande arbetsmarknadpolitiska program med en mångfald av åtgärder. Dessa åtgärder är både sådana som syftar till att påverka arbetsutbud, arbetskraftsefterfrågan och matchningen på arbetsmarknaden (dessa tre delar brukar benämnas den aktiva arbetsmarknadspolitiken) och de som ger ersättning till dem som är arbetslösa (den passiva arbetsmarknadspolitiken).

Samtigt gäller dock att det inte finns en nordisk modell för arbetsmarknadspolitik utan snarare lika många modeller som antalet länder (och vi kan tillägga att de tre autonoma regionerna har egna utformningar av sin arbetsmarknadspolitik). Det är också viktigt att uppmärksamma att politiken inte ligger fast över decennierna. Det sker ständigt förändringar som påverkas av de förändringar som sker i ekonomierna och arbetsmarknaderna, men också inte minst av den politiska diskussionen och de beslut tas på politisk nivå.

Utformingen av politiken i ett land påverkas såväl av egna erfarenheter som av erfarenheter i andra länder, både positiva och negativa. Detta att lära av andra länders erfarenheter kan leda till bättre beslut. Det finns alla anledning att studera vad som görs i de olika länderna i Norden på arbetsmarknadspolitikens område och jämföra utformningen av politiken och också de resultat av politiken enligt olika utvärderingar.

Denna rapport innehåller en jämförelse av arbetmarknadspolitiken i de fem länderna och de tre autonoma regionerna i Norden. Jämförelsen omfattar både den aktiva och den passiva arbetsmarknadspolitiken. Bland annat uppmärksammas i vilken grad politiken är centraliserad och decentraliserad och i vilken utsträckning åtgärderna är riktade till olika grupper med speciella problem på arbetsmarknaden. Många reformer har gjorts under det senaste decenniet. De uppmärksammas i rapporten liksom de utvärderingar som har gjorts av dem. Rapporten avslutas med ett försök att ta fasta på erfarenheter som kan ligga till grund för rekommendationer.

Eskil Wadensjö, professor i arbetsmarknadsekonomi vid Institutet för social forskning (SOFI) vid Stockholms universitet. 
Det har varit en stor mängd personer inblandade för att möjliggöra denna rapport. Framförallt alla de på myndigheter, regeringskanslier och forskningsinstitutioner runt om i Norden som har ställt upp på intervjuer. Tack, utan er hade denna rapport inte blivit till.

Vi vill också tacka dr. Svala Guðmundsdóttir och Gylfi Dalmann Aðalsteinsson (University of Icelands handelshögskola), Olli Oosi (Owal Group), Gunnel Hedman och Anders Berg (Mapsec), samt Anders Gøgsig Randrup och Martin Bæksgaard Jakobsen (Oxford Research Danmark) och Tor Egil Viblemo och Bernhard Weigel (Oxford Research Norge). Alla har varit inblandade i datainsamling och analys i detta arbete.

Mats Kullander och Lisa Lönnes Tönnroos, Oxford Research. 


\section{Sammanfattning}

Syftet med denna studie är att undersöka om organiseringen och styrmekanismer har någon betydelse för utfallet av arbetsmarknadspolitiken. Ger modell A större måluppfyllelse än modell B? Ger en åtgärd eller reform i system $A$ andra resultat och effekter än en åtgärd eller reform i system B?

För att kunna förmedla en gedigen bild av arbetsmarknadspolitiken i de olika nordiska länderna genomfördes datainsamlingen landsvis med hjälp av ett tvärnordiskt team och på så sätt inkludera samtliga nordiska språk. Totalt har ett sjuttiotal intervjuer i de fem länderna och de tre autonoma regionerna gjorts under arbetet med denna studie. Alla intervjurespondenter finns listade i källförteckningen i kapitel 10. Därutöver har en stor mängd av olika dokument, utvärderingar och rapporter analyserats i samtliga länder. Även de relevanta lagarna i respektive land har studerats för att skönja likheter och skillnader i de olika systemen.

Denna rapport använder begreppen aktiva och passiva arbetsmarknadsåtgärder. Även OECD och många andra organisationer använder dessa begrepp. Med passiva åtgärder avses någon form av ersättning, bland annat arbetslöshetsersättning, som den arbetslöse kan vara berättigad till. Ofta innebär villkoren för att erhålla arbetslöshetsersättning att den arbetslöse ska vara aktiv på något sätt, till exempel att söka arbete. ${ }^{1}$ När det gäller åtgärder som räknas som aktiva brukar det inkludera matchning, utbuds- och efterfrågeinriktade åtgärder. För det första ska arbetsförmedlingen ansvara för en effektiv matchning av lediga platser och arbetssökande. För det andra används olika typer av arbetsmarknadsutbildningar eller praktik. För det tredje finns det också efterfrågeinriktade åtgärder såsom olika former av anställningsstöd. ${ }^{2}$

Internationellt talas det ofta om den nordiska modellen - en modell som sammanlänkar de nordiska länderna och dess välfärdssystem till en sammanhållen linje. Mycket förenar de nordiska länderna, exempelvis en förhållandevis stark offentlig sektor, en till stor del skattefinansierad familjepolitik och ambitiös välfärd. Vidare förenas de nordiska länderna i en till stor del avtalsreglerad arbetsmarknad där sociala parter har stort inflytande och där det offentliga strävar efter tillväxt, hög sysselsättning och

\footnotetext{
${ }^{1}$ Den stora omvandlingen - Svensk arbetsmarknadspolitik under tre decennier, Arbetsmarknad \& Arbetsliv, årg 18, nr 3, hösten 2012.

${ }^{2}$ Ibid.
} 
fördelningspolitik. Det finns således en god grund för lärande på tvärs mellan länderna, vilket denna rapport kan bidra till.

\section{Organisering av arbetsmarknadspolitiken}

Det går att urskilja en dominerande linje bland länderna i Norden. Huvudlinjen är en hierarkisk struktur där huvudansvaret för arbetsmarknadssystemet och politiken ligger på respektive lands arbetsmarknadsdepartement/ministerium där arbetsmarknadsministern har det yttersta ansvaret för utformningen av arbetsmarknadspolitiken.

\section{Styrinstrument}

Lagstiftning är ett viktigt styrinstrument som reglerar många delar av arbetsmarknaden och arbetsmarknadspolitiken i alla länder. Dock används lagstiftningen i Finland, Island och Sverige i större utsträckning för att styra än i Danmark och Norge.

Ekonomiska incitament har den mest framträdande rollen i Danmarks arbetsmarknadspolitik vars refusionssystem (refusionsordning) är en central del av statens styrning av kommunernas arbetsmarknadsinsatser.

Det finns en risk med att använda ekonomiska incitament som styrinstrument och det är att fokus kan hamna på att få så mycket pengar tillbaka som möjligt (som i Danmark) och på att minska utgifterna (som i Finland, Island och Sverige). När fokus ligger på utgifterna finns en risk för att fokus hamnar på dem som står närmare arbetsmarknaden och kortsiktiga lösningar eftersom detta ger större vinst (eller mindre förlust).

Samtliga nordiska länder utgår från en arbetsmarknadsmodell som starkt inkluderar arbetsmarknadens parter. I Danmark, Finland och Sverige är arbetsmarknadens parter bl.a. involverade i och med att A-kassorna är anknutna till fackföreningarna. På Island behandlas alla arbetsmarknadsrelaterade frågor i trepartskonstellationer. I Norge har arbetsmarknadens parter ett informellt inflytande och agerar aktivt genom brev, samråd med mera. 
Figur 1: Uppföljningssystemen per land

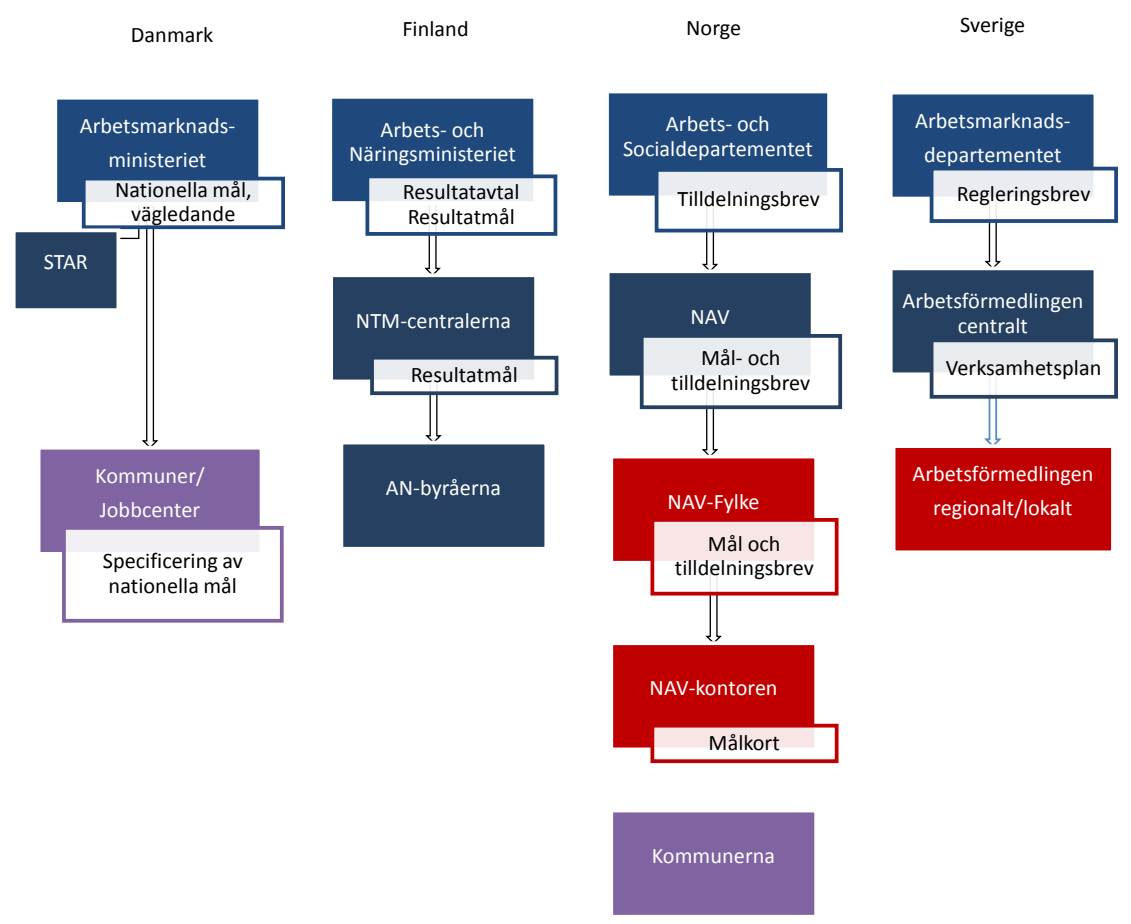

\section{Centralisering och decentralisering}

Graden av centralisering/decentralisering har i Norden påverkats av olika reformer som påverkat förhållandet mellan lokal autonomi och centraliserad styrning. Det är belagt i flera studier kring vikten av en balans mellan lokal autonomi för att kunna uppfylla lokala behov å ena sidan och mellan likvärdighet i hela landet för rättvisa men också effektivitet i åtgärder, vilket även denna studie indikerar.

I och med strukturreformen i Danmark år 2007 lades den statliga arbetsförmedlingen ner och dess ansvar flyttades till kommunerna och de nyetablerade jobbcentren. I strävan efter att säkerställa en välfungerande arbetsmarknad gjordes i Finland en reform 2013 som innebar en hopslagning av de då 74 lokala arbetsmarknadskontoren till de nuvarande 15 regionala arbets- och näringsbyråerna (AN-byråerna).

NAV-reformen i Norge år 2005-2006 innebar en sammanslagning av den statliga arbetsmarknadsmyndigheten och socialförsäkringsmyndigheten till en gemensam 
statlig myndighet integrerad på lokal nivå med delar av kommunens socialtjänst genom lagar och avtal. Allt samlades inom den nya myndigheten NAV. Själva arbetsförmedlingen via NAV-kontoren sker dock genom ett likvärdigt partnerskap mellan stat och kommun. Kommunerna fick därmed en roll i en större samlad organisation av arbetsmarknadspolitiken. Det innebär en unik lösning där den statliga och kommunala portföljen är samordnad på lokal nivå.

En gemensam nämnare för kommunernas roll i Norden är att även om det inte finns formella krav på kommunerna att genomföra aktiva arbetsmarknadsinsatser sker detta många gånger på kommunernas egna initiativ. Kommunerna ansvarar för ekonomiskt stöd till arbetslösa i form av försörjningsstöd, de kan ha ett ansvar för sina arbetslösa invånare eller ett ansvar för en viss grupp av arbetslösa som till exempel långtidsarbetslösa. Styrning från statligt håll har ökat denna typ av utgifter för kommunernas passiva arbetsmarknadsinsatser i Finland, Island och Sverige. Det har i sin tur lett till ökad kommunal involvering i aktiveringen av arbetslösa för att minska dessa utgifter.

\section{Färöarna, Grönland och Åland}

På Färöarna har man valt en helt unik lösning för att styra den aktiva arbetsmarknadspolitiken, som saknar motsvarighet i något annat nordiskt land. På Färöarna är ALS nämligen ensam ansvarig organisation för både aktiveringsåtgärder, det vill säga arbetsförmedling, arbetsmarknadsutbildning, rådgivning med mera, samt för arbetslöshetsförsäkringen. Det unika är också att ALS är så fristående från statsapparaten i övrigt. Det har inte skett några grundläggande förändringar i den färöiska arbetsmarknadspolitiken sedan 1992, när ALS-lag antogs i parlamentet. Dock har aktiveringspolitik blivit gradvis viktigare på Färöarna som ett medel till att minska arbetslösheten och få arbetskraften mer rörlig, särskilt i och med den senaste ändringen av lagstiftningen 2013.

Grönlands självstyre (Naalakkersuisut) har ett formellt överordnat ansvar för arbetsmarknadspolitiken, genom departementet/ministeriet för näringsliv, arbetsmarknad och handel. Det är departementet som utvecklar arbetsmarknadspolitiken och genomför stora delar av sysselsättningsåtgärderna. Förutom departementet har de fyra kommunerna på Grönland också ansvar för implementeringen av arbetsmarknadspolitiken.

I Grönland har den viktigaste reformen på senare tid implementerats under 2016. Det är en sammanslagning av de kommunala arbetsmarknadskontoren och jobbcenter. Med lagändringen skapas det en gemensam ingång (one-stop-shop) till både vägledning, vidareutbildning och utformning av individuella handlingsplaner till arbetslösa. 
Ålands arbetsmarknads- och studieservicemyndighet (AMS) har mycket stort inflytande över arbetsmarknadspolitiken på Åland. Ålands landskapsregering har dock formellt överordnat ansvar, och då genom näringsavdelningen, som årligen antar en verksamhetsplan med närmare inriktning på arbetsmarknadspolitiken i landskapet. Förslaget till plan utarbetas av AMS som på det sättet får inflytande. Det har inte varit några betydande reformer inom arbetsmarknadspolitiken på Åland de senaste tio åren.

\section{Motiv till reformer}

I Sverige och till viss del i Danmark har reformer varit en följd av politiskt motiverade beslut, ofta som en följd av regeringsskifte, även om reformerna i Danmark har drivits av en bred majoritet i Folketinget. I Finland och Island har det varit yttre omständigheter som tvingat fram reformer, såsom finanskrisen i Island med kraftigt ökad arbetslöshet som följd och den dåliga ekonomiska utvecklingen i Finland med mindre resurser till arbetsmarknadspolitiken.

Ett fokus på aktiveringspolitik, eller "arbetslinjen", har i samtliga länder lyfts som en grundläggande förutsättning för att utöka arbetskraftsdeltagandet och därmed bibehålla eller utveckla välfärden. Flera länder har även satsat på att minska sjukfrånvaron, och satt ett ökat fokus på rehabilitering/revalidering. Ett annat återkommande motiv till organisatoriska reformer i flera av länderna har varit problem kring ansvarsfördelning, där olika aktörer sett den enskilde som någon annans ansvar. Inte minst förefaller sådana problem vara vanligt förekommande mellan kommun och stat. I flera av länderna har de reformer som under det senaste decenniet implementerats inom styrning och organisation tydliga drag av New Public Management. I samtliga länder har också digitaliseringen i någon mån utvecklat servicen och därigenom drivit reformer.

\section{Sammanfattande slutsatser}

\section{Styrning och organisering på central nivå}

En genomgång av de reformer som gjorts under det senaste decenniet visar att styrningen och organiseringen av arbetsmarknadspolitiken är under en nästan ständig omvandling. Finland har till exempel haft återkommande justeringar av ansvarsfördelning och aktörers roll och utbud av tjänster. Island har befunnit sig på motsatt sida av skalan, med relativt få förändringar i systemet. Den övergripande trenden i Norden 
har varit att reformerna bidragit till en centralisering av styrningen, men med bibehållet eller stärkt lokalt mandat.

Organisatoriska sammanslagningar ger, åtminstone på kort och medellång sikt, sällan de resultat som det var tänkt. Det finns många exempel på det i Norden, nya arbets- och näringsministeriet i Finland, NAV i Norge hade till exempel en lång startsträcka där färre kommer i arbete än innan reformen. Däremot har bildandet av NAV till stor del åtgärdat det problem som finns i alla nordiska länder, att personer hamnar mellan stolarna och skickas runt mellan myndigheter.

Sammanslagningar och organisatoriska förändringar bör användas med försiktighet. De kan bidra till att förenkla för medborgaren genom en-dörrs-lösningar (onestop-shop). Det verkar ha bäst effekt för dem som står långt från arbetsmarknaden, vilka också är prioriterade målgrupper i samtliga länder. Det innebär att det norska exemplet med fördel kan användas som inspiration för andra länder.

Trots en hög reformtakt i Norden har den grundläggande inriktningen på arbetsmarknadspolitiken varit likartad. Det har primärt varit fokus på utbudssidan (det vill säga de arbetssökande och deras förmåga och incitament till arbete) och bara sekundärt på efterfrågesidan (det vill säga arbetsgivare och näringslivet och viljan att anställa). Finland står dock ut i och med att man där kopplat samman arbetsmarknadspolitik och näringslivspolitik, både genom sammanslagning på departementsnivå och genom den ökade rollen för NTM-centralerna.

I Danmark, Norge och Sverige har strävan efter en starkt kontrollerad politik lett till att man först implementerat en strikt målbaserad styrning. I samtliga länder har styrmekanismerna på senare år konstaterats alltför rigida. Styrningen har i alltför hög grad kommit att fokusera på att uppfylla detaljerade, åtgärdsspecifika målsättningar. Detta har motverkat möjligheten till den anpassning till såväl lokala förutsättningar som individuella behov som en effektiv arbetsmarknadspolitik kräver.

I de länder som nyligen svängt mot mer evidensbaserad politik finns få eller inga utvärderingar kring hur detta fungerar ännu. Det mesta tyder dock på att evidensbaserad politik - med exempelvis professionaliserade samtal i möten med klienter - fungerar. Det är värdefullt och uppskattat för den enskilda arbetsförmedlaren, enligt de studier som gjorts och vilket våra intervjuer bekräftar, att väl beprövade åtgärder och insatser finns i verktygslådan, så länge det är upp till den egna bedömningen om insatsen ska användas eller ej.

Ekonomiska incitament som inslag i styrningen har implementerats i Norden under den undersökta perioden, i mest renodlad form i Danmark.

Ekonomiska incitament med direkt eller indirekt verkan på kommunernas utgifter har ökat kommunernas roller i aktiveringen av arbetslösa. Ekonomiska incitament används i syfte att minska arbetslösheten men eftersom sådana incitament i Finland, 
Island och Sverige inneburit ökade kostnader för kommunerna har de varit tvungna att bli aktiva aktörer inom arbetsmarknadspolitiken, om de inte redan varit det.

Incitamentstrukturer kan leda till icke önskvärda snedvridningar i målgrupper. Till och med väldigt detaljerad uppföljning, med indikatorer för olika målgrupper etc., kan få snedvridande effekter, även utan ekonomiska incitament kopplade till styrningen.

I samtliga nordiska länder har privata aktörer involverats i någon grad i implementeringen av arbetsmarknadspolitiken. Det är dock svårt att dra generella slutsatser kring upphandling av tjänster i sig, utförandet av själva upphandlingen verkar vara av större relevans. Huruvida systemen och de arbetssökande individerna gynnas av fler privata aktörer beror således inte på om privata alternativ finns som valbart alternativ eller inte, utan på de offentliga arbetsförmedlingarnas kompetens i att upphandla, styra och följa upp de privata aktörerna.

\section{Decentralisering och kommunernas roll}

Forskning visar att tydliga styrkedjor och klara roller, med en fungerande styrkedja hela vägen från departement till implementerande aktörer, är viktiga för en effektiv implementering av arbetsmarknadspolitiken.

Utvärderingarna av effekterna av de reformer som gjorts i Norden visar att det tar lång tid efter en reform innan den typen av klar och tydlig styrkedja gestaltar sig. Det bekräftas också i de intervjuer längs med styrkedjan som gjorts i denna studie.

Avvägningar mellan en styrning som betonar lokal- och individanpassning å ena sidan och en mer centraliserad och likformig styrning å andra sidan kan tänkas ha olika påverkan på olika grupper av arbetslösa. Personer som står längre bort ifrån arbetsmarknaden och mindre arbetsgivare som fungerar lokalt vinner ofta på ett system som i högre grad möjliggör lokal anpassning. ${ }^{3}$ Intervjuer på lokal nivå verkar stödja tanken om att viss grad av autonomi krävs för att kunna erbjuda individualiserad service. Detta också den riktning som har tagits i de flesta länder.

Kommunen har blivit en viktigare aktör då vissa arbetslösa som av olika anledningar inte längre har rätt till arbetslöshetsersättning eller aktivitetsstöd istället ansöker om försörjningsstöd. Kommunerna har också involverats på ett mer medvetet och aktivt sätt i de flesta länder. Denna utveckling har haft två separata målsättningar: dels att knyta samman aktiva och passiva åtgärder, dels att möjliggöra mer integrerad service för personer som står långt ifrån arbetsmarknaden och kan tänkas vara i behov av sociala tjänster som ett komplement till arbetsförmedlingens tjänster.

\footnotetext{
${ }^{3}$ Työpolitiikan palvelurakennearviointi: Työpolitiikan palvelurakenteen ohjaus ja kolmikantayteistyö. Valmisteluryhmän raportti. TEM 28.10.2014. s. 17-18.
} 
Kommunerna har starka incitament för att få personer med försörjningsstöd i arbete. ${ }^{4}$ Det är då bättre att involvera kommunerna i den statliga arbetsmarknadspolitiken (Danmark, Norge och delvis Finland) än att det uppstår parallellsystem (Sverige, delvis Finland) där det finns en risk att kommunerna huvudsakligen drivs av att minska utgifterna snarare än att minska arbetslösheten, och där de åtgärder som initieras inte utformas på ett effektivt sätt. ${ }^{5}$

\section{Rekommendationer - Vad kan länderna lära av varandra?}

Trots, eller tack vare, alla olikheter mellan ländernas vägval finns det goda möjligheter att se på de nordiska grannländerna för inspiration om hur arbetsmarknadspolitiken kan utvecklas.

- Initiera ett institutionaliserat samarbete på nordisk nivå mellan de nationella offentliga myndigheter som ansvarar för implementeringen av arbetsmarknadspolitiken. Detta är motiverat dels av potentialen för ömsesidigt lärande, dels av det faktum att Norden har en fungerande gemensam arbetsmarknad som skulle gynnas av ett tätare samarbete mellan dem som arbetar med arbetsförmedling.

- Reformtakten i Norden har generellt varit hög. De intervjuer som gjorts i styrkedjan visar att det ibland har varit svårt för de anställda att hänga med $i$ svängarna. Ett särskilt stort intresse har visats för olika typer av sammanslagningar av organisationer, som på olika vis har förekommit i varje land. Sammanslagningar kan naturligtvis ha både positiva och negativa effekter, vilket utvärderingar också har visat. Om de bidrar till att minska avståndet mellan passiv och aktiv arbetsmarknadspolitik, skapa en-dörrs-lösningar samt undvika att personer faller mellan stolarna, finns det goda exempel i Norden på att de kan ha positiva effekter. Beslutsfattare bör vara medvetna om att det under en lång övergångsperiod kan ge sämre resultat än före reformen, innan den nya organisationen satt sig. Längden för sådana övergångsperioder kan lätt underskattas.

\footnotetext{
${ }^{4}$ Se bl.a Martin, J.P. (2014) Activation and Active Labour Market Policies in OECD Countries: Stylized Facts and Evidence on their Effectiveness. IZA Policy Paper No. 84.

${ }^{5}$ Och ofta inte heller ett sätt som är meningsfullt för deltagarna. Intervju med Katarina Thorén som forskat om kommunala arbetsmarknadsåtgärder.
} 
- En pendelrörelse över tid mellan detalj-/aktivitetsstyrning och mer återhållsam mål-/resultatstyrning kan identifieras i Norden. I mitten av oo-talet var pendeln långt åt detaljstyrning i princip i hela Norden. Därefter har pendeln rört sig mot en större lokal autonomi, och ett större förtroende för den expertis som finns på lokal nivå i de aktuella myndigheterna. De utvärderingar som finns visar samstämmigt på goda effekter av en ökad lokal autonomi, och större användning av målstyrning snarare än aktivitetsstyrning. Särskilt positivt är detta för dem som står långt ifrån arbetsmarknaden. Därför bör ministerier och andra aktörer uppe i styrkedjan vara försiktiga med nya styrsignaler.

- Användningen av ekonomiska incitament mellan aktörer i systemet samt även rigida uppföljningskrav på aktivitetsnivå kan ge upphov till oönskade snedvridningseffekter. Vanligen yttrar det sig genom att en viss målgrupp prioriteras på ett oönskat sätt på bekostnad av en annan grupp. Det mesta tyder på att tydliga mål för arbetsmarknadspolitiken, uppdelade per målgrupp, är en tillräcklig styrsignal för att olika målgrupper ska prioriteras i önskad utsträckning.

- Effektiviteten i att använda privata aktörer beror i hög utsträckning på de system som finns för upphandling, kontroll, tillsyn, uppföljning och utvärdering från den upphandlande myndighetens sida. Detta skulle kunna vara en första punkt för ett mer institutionaliserat samarbete mellan arbetsförmedlingarna i Norden, där kunskapsutveckling kring privata kompletterande aktörer kan stimuleras. Åtminstone i Danmark, Finland och Sverige är den juridiska situationen kring dessa upphandlingar snarlik. På sikt kan en nordisk marknad för sysselsättningsåtgärder byggas upp, med mer professionaliserade aktörer som följd.

- Kommunens roll i arbetsmarknadspolitiken har ökat i takt med att "arbetslinjen" gjort att kraven i ersättningssystem under statligt ansvar stramats åt, vilket gjort att fler hänvisas till de ersättningssystem som är kommunens ansvar, till exempel försörjningsstöd. Detta har drivit kommunerna att initiera egna arbetsmarknadsåtgärder i hela Norden. Detta riskerar, särskilt i länder med mindre samarbete mellan arbetsförmedling och kommuner, såsom tidigare var fallet i Sverige till exempel, att skapa parallella system där åtgärderna inte är särskilt effektiva. Därför är det centralt att den statliga arbetsförmedlingen har ett tätt och dynamiskt samarbete med kommuner, och att kommuner har ett inflytande över de arbetsmarknadsåtgärder som sker i den egna kommunen. 



\section{Inledning}

En rapport från $2014^{6}$ om utmaningar för den nordiska modellen pekar på tre megatrender som Norden måste hantera; globalisering, den demografiska utmaningen samt den digitala revolutionen. För att bemöta dessa förändringar rekommenderade författarna olika prioriteringar som måste tydliggöras för att Norden ska bibehålla sin fungerande välfärdsmodell. En av dessa prioriteringar var att förbättra arbetsmarknadens funktionssätt, det vill säga bättre matcha arbetssökande mot de jobb som finns. Särskilt fokus skulle enligt rapporten ligga på att fokusera de arbetssökande till produktiva arbeten. Rapporten konstaterar:

Endast kombinationen av högt arbetskraftsutbud och låg arbetslöshet tillåter uppnåendet av de sysselsättningsgrader som behövs för att finansiera de offentliga utgiftsnivåerna som är nödvändiga för den nordiska modellen. Höga sysselsättningsgrader är också viktiga för att hålla inkomstojämlikheter i schack.?

De nordiska länderna har likartade ambitioner för sina välfärdsstater, där en hög sysselsättning är en grundbult för samhällets sociala och ekonomiska hållbarhet. Målet om hög sysselsättning kombineras med försäkringar och bidrag som ska säkerställa en grundtrygghet för dem som står utan arbete, samtidigt som de ska ge incitament att aktivt söka nya jobb. Det är en uppgift för det offentliga i samtliga nordiska länder att förbättra matchningen på arbetsmarknaden, öka de arbetssökandes kvalifikationer för att öka deras anställningsbarhet samt att säkerställa grundtrygghet för alla medborgare. Parterna på arbetsmarknaden har stort inflytande på villkoren på arbetsmarknaden. Den nordiska staterna kännetecknas också av en tät koppling mellan välfärds- och arbetsmarknadspolitik. En grundtanke i Norden är att anställningar i branscher som inte klarar sig i den internationella konkurrensen inte ska skyddas genom olika typer av stöd. Istället ska arbetskraften med hjälp av generösa arbetslöshetsersättningar och omställningsstöd i form av arbetsmarknadspolitiska insatser kunna hitta nya jobb i mer framgångsrika branscher.

\footnotetext{
${ }^{6}$ Nordiska Ministerrådet, TemaNord 2014:531: The Nordic model - challenged but capable of reform.

${ }^{7}$ lbid. 5362 .
} 
Så långt förenas de nordiska staterna, och det är detta system som brukar kallas den nordiska modellen. Däremot finns det en stor variation i hur de Nordiska länderna har valt att förverkliga, styra och implementera arbetsmarknadspolitiken. Det varierar vilka typer av myndigheter som är ansvariga, hur insatserna finansieras, vilken roll kommunerna har och vilka som har inflytande över politiken. Inte minst har det skett ett stort antal reformer på området under 2000-talet. I Norge har det skett en stor sammanslagning av myndigheter inblandade i arbetsmarknadspolitiken till en enda supermyndighet. I Danmark har ansvaret för arbetsmarknadspolitiken helt kastats om, från statligt till kommunalt håll, parallellt med en stor kommunreform. I Island har arbetsmarknadspolitiken ställts inför en av de största kriserna i Norden i modern tid, med en rekordsnabb ökning av arbetslösheten från 1 till 9,3 procent under februari 2010. Alla dessa stora händelser och reformer kan ses som en prisma genom vilka effekter av olika val inom arbetsmarknadspolitiken kan studeras. Detta är just Oxford Researchs ambition med denna rapport. Syftet är att ta reda på vad som fungerar bra och vad som fungerar sämre.

\section{$1.1 \quad$ Metod}

\subsubsection{Tvärnordiskt team för datainsamling och rapportering}

För att kunna förmedla en gedigen bild av arbetsmarknadspolitiken i de olika nordiska länderna genomfördes datainsamlingen landsvis med hjälp av ett tvärnordiskt team för att inkludera samtliga nordiska språk. Studien leddes av Mats Kullander vid Oxford Research i Stockholm. Projektmedarbetare vid Oxford Researchs kontor i Danmark, ${ }^{8}$ Norge $^{9}$ och Sverige ${ }^{10}$ genomförde datainsamlingen i dess respektive länder. För Island sköttes rapportering och analys av Svala Guðmundsdóttir och Gylfi Dalmann Ađalsteinsson, båda från University of Iceland. För Finland samarbetade Olli Oosi, konsult och arbetsmarknadsexpert från Helsingfors som har utfört liknande komparativa studier förut på uppdrag av den finska regeringen med Lisa Tönnes Lönnroos, som tidigare ansvarat för arbetsmarknadspolitisk bevakning om Norden på EU-kommissionen. För de autonoma regionerna gjordes datainsamling av medarbetare på Oxford Researchs kontor i Danmark och Sverige, med hjälp av centrala informatörer i respektive region.

\footnotetext{
${ }^{8}$ Martin Baeksgaard Jakobsen och Anders Gøgsig Randrup.

${ }^{9}$ Tor Egil Viblemo.

${ }^{10}$ Mats Kullander, Lisa Tönnes Lönnroos, Avin Ali Akbar.
} 
För att säkerställa att datainsamling och analys fokuserades på relevanta aspekter togs hjälp av experter som bistått längs med hela arbetet med denna studie. Experterna har varit professor Eskil Wadensjö vid Stockholms universitet och Olli Oosi. Eskil Wadensjö har mångårig erfarenhet av studier av såväl arbetsmarknadens funktionssätt i allmänhet som arbetsmarknadsinsatser i Norden i synnerhet. Han har varit verksam som forskare i både Sverige och Danmark och har utfört flera utredningar åt regeringarna i Sverige och Danmark med syfte att förbättra arbetsmarknadspolitiken. Dessutom har Gunnel Hedman och Anders Berg, ${ }^{11}$ båda med lång erfarenhet av att analysera styrning och av att studera arbetsmarknadsfrågor, bistått vid både analys och datainsamling, främst avseende Sverige.

\subsubsection{Tillvägagångssätt för datainsamling och rapportering}

Studien initierades under sommaren 2015 med ett uppstartsmöte med Nordiska Ministerrådets arbetsmarknadsutskott, för att diskutera viktiga begrepp och avgränsningar i studien. Därefter utformades en datainsamlingsmall, för att säkerställa att all information som togs fram i studien var relevant och jämförbar. Denna datainsamlingsmall reviderades sedan efter input från först experterna involverade i gruppen, sedan efter input från arbetsmarknadsutskottets möte i Oslo i september 2015. Därefter hade arbetsgruppen ett första tvärnordiskt möte där alla deltog och studien diskuterades. Därefter skedde datainsamling i respektive land som resulterade i en omfattande rapportering och material från varje land.

Oxford Research tillsammans med Eskil Wadensjö sammanställde och systematiserade resultaten i landrapporterna för att kunna avgöra vilka likheter och skillnader det finns och vilka områden som behövde undersökas ytterligare. I samband med detta utformades också ett antal hypoteser kring vad som avgör hur framgångsrikt ett system är. Dessa hypoteser har sedan styrt analysen av det material som samlats in. De hypoteser som diskuterats berörs på olika sätt i kapitel nio.

Arbetsgruppen, inklusive experterna, träffades återigen i Stockholm i april 2016 för en analysworkshop där preliminära slutsatser och hypoteser för det framtida arbetet diskuterades. En andra datainsamlingsrunda i samtliga länder samt de autonoma regionerna tog sedan vid, med särskilt fokus på de reformer som genomförts under senare år, och de analyser av deras effekter som gjorts.

\footnotetext{
${ }^{11}$ Från konsultbolaget Mapsec.
} 


\subsubsection{Underlag och data}

Både litteratur och intervjuer har använts i denna studie för att få ett så gediget dataunderlag som möjligt. Intervjuerna har fokuserat på olika typer av respondenter:

- Seniora personer i de ministerier och departement som är ansvariga för arbetsmarknadssystemen i respektive land.

- Direktörer och/eller chefer i de ansvariga statliga myndigheterna.

- Personer som ansvarat för viktiga utredningar åt regeringarna (till exempel Carsten Koch i Danmark).

- Forskare med långt tidsperspektiv som kunnat belysa förändringar i systemen.

Totalt har ett sjuttiotal intervjuer i de fem länderna och de tre autonoma regionerna gjorts under arbetet med denna studie. Alla intervjurespondenter finns listade i källförteckningen.

Därutöver har en stor mängd av olika dokument, utvärderingar och rapporter analyserats i samtliga länder. Även de relevanta lagarna i respektive land har studerats för att skönja likheter och skillnader i de olika systemen (se litteraturlista).

\subsection{Begrepp och avgränsningar}

För att kunna studera olika val i styrning och organisering av arbetsmarknadspolitiken i Nordens fem länder och tre autonoma regioner, utfört av ett tvärnordiskt team med danska, finska, isländska, norska och svenska som modersmål, är det viktigt med en samsyn kring centrala begrepp. Den största utmaningen med att genomföra en jämförande analys av arbetsmarknadspolitik i Norden är skillnaderna i hur olika ord och begrepp uppfattas i de olika länderna. Av den anledningen valde Oxford Research att inte förhålla sig strikt till färdiga definitioner av centrala begrepp, såsom styrning, arbetsmarknadspolitik eller reform. Det finns en risk att antingen bli för snäv och därmed utesluta viss information som är relevant i vissa länder eller att bli för bred och därmed sakna den stringens som krävs för jämförbarhet. Istället tydliggjordes vissa avgränsningar för studien $\mathrm{i}$ instruktionerna inför projektmedarbetarnas första datainsamling. Därefter användes en snöbollsmetod för att landa i en gemensam förståelse av vad organisering och styrning av arbetsmarknadspolitik innebär i Norden.

Denna rapport använder begreppen aktiva och passiva arbetsmarknadsåtgärder. Även OECD och många andra organisationer använder dessa begrepp. Med passiva åtgärder avses någon form av ersättning, bland annat arbetslöshetser- 
sättning, som den arbetslöse kan vara berättigad till. Ofta innebär villkoren för att erhålla arbetslöshetsersättning att den arbetslöse ska vara aktiv på något sätt, till exempel att söka arbete. ${ }^{12}$

När det gäller åtgärder som räknas som aktiva brukar det inkludera matchning, utbuds- och efterfrågeinriktade åtgärder. För det första ska arbetsförmedlingen ansvara för en effektiv matchning av lediga platser och arbetssökande. För det andra används olika typer av arbetsmarknadsutbildningar eller praktik. För det tredje finns det också efterfrågeinriktade åtgärder såsom olika former av anställningsstöd. ${ }^{13}$

Det är viktigt att betona att det som benämns som passiva åtgärder inte alls betyder att det inte ställs krav på att personer ska vara aktiva. Sådana krav har tvärtom ökat i betydelse över tid i Norden såväl som i andra länder. De flesta ersättningssystem som i denna rapport kategoriseras som passiva inkluderar någon form av aktiveringskrav. ${ }^{14}$

En viktig avgränsning som gjorts i samråd med Nordiska Ministerrådet är att enbart involvera den del av välfärdssystemen som rör sysselsättningsfrågor. Det gör att ersättningssystem som inte syftar till eller innehåller mekanismer för att få personer i arbete inte har inkluderats i denna studie.

Oxford Research använde sedan en snöbollsliknande metod för att säkerställa att relevant och jämförbar information samlades in till analysen. Snöbollsmetoden gick ut på att först låta respektive land rapportera om organisering och styrning av arbetsmarknadspolitiken utifrån landets egna definitioner och begrepp samt utifrån det avgöra vilka kompletteringar och avgränsningar som behövs för att möjliggöra en jämförande analys.

\subsection{Disposition}

Rapporten inleds med ett kapitel om hur arbetsmarknaden i de nordiska länderna förändrats de senaste tjugo åren med avseende på arbetslöshet, sysselsättning och offentliga medel till arbetsmarknadspolitiken. Detta kapitel är viktigt för att ge en bild av hur utmaningarna och prioritering skiljer sig mellan de nordiska länderna. Kapitel tre innehåller sedan en översiktlig presentation av hur systemet för att implementera arbetsmarknadspolitik ser ut i respektive land. Detta presenteras sche-

\footnotetext{
${ }^{12}$ Den stora omvandlingen - Svensk arbetsmarknadspolitik under tre decennier, Arbetsmarknad \& Arbetsliv, årg 18, nr 3, hösten 2012.

${ }^{13}$ Ibid.

${ }^{14}$ Det gör att begreppet passiv kan vara missvisande, men det används fortfarande i internationella institutioner och $\mathrm{i}$ forskning och därför även i denna rapport.
} 
matiskt med ett organisationsschema med olika aktörer som är involverade och deras inbördes relationer. Kapitel 4 studerar mer i detalj de olika styrinstrument som används i Norden för att se till att politikens intentioner förverkligas. Kapitel 5 vänder blickarna till de autonoma regionerna, för att se hur organisering och styrning av arbetsmarknadspolitiken fungerar i dessa regioner. Kapitel 6 studerar hur centraliserade eller decentraliserade systemen är, hur styrkedjan till lokal nivå ser ut och kommunernas roll inom arbetsmarknadspolitiken. Hela rapporten fram tills nu är en kartläggning och beskrivande analys av organisering av arbetsmarknadspolitiken i Norden. ${ }^{15}$ Det är i någon mån en ögonblicksbild, som inte beskriver förändring över tid och de reformer som genomförts. Den senare delen av rapporten fokuserar därför på de reformer som gjorts och effekterna av dessa.

Kapitel sju studerar alltså de reformer som gjorts inom styrning och organisering av arbetsmarknadspolitiken under 2000-talet. Tanken är att reformer kan användas som ett undersökningsobjekt för att studera effekter av olika system för organisering och styrning av arbetsmarknadspolitiken, eftersom det då är möjligt att studera effekter av förändringar i systemet. Kapitel 8 analyserar därför utvärderingar och analyser av reformerna. Kapitel 9 redogör för de slutsatser och rekommendationer som kommit ut av rapporten.

Det finns två bilagor till rapporten som också bidrar med insikter kring hur arbetsmarknadspolitiken implementeras i Norden. Bilaga 1 innehåller en översikt av arbetsmarknadspolitikens verktygslåda i Norden. Där studeras hur förmedlings- och matchningsaktiviteter, arbetsmarknadsutbildning och subventionerade anställningar används i de olika länderna och autonoma regionerna i Norden. Det innehåller vidare en redogörelse kring två specifika målgrupper som är gemensamma i alla länder, nämligen långtidsarbetslösa och NEETs. Vidare innehåller bilagan en redogörelse för de olika ersättningssystemen i Norden när man inte har ett arbete. Bilaga 2 ska ses som ett komplement till kapitel 2. Det studerar deltidsarbete i Norden, för att ytterligare belysa hur Nordens arbetsmarknader fungerar.

\footnotetext{
${ }^{15}$ Kapitel 2-6 (plus bilagor) är därmed tänkta att motsvara del I i den projektbeskrivning som Nordiska Ministerrådets arbetsmarknadsutskott presenterade för att initiera projektet. Kapitel 7-9 motsvarar del II.
} 


\section{Arbetsmarknaden i Norden}

Målet med denna rapport är att genom att jämföra de olika systemen för att implementera arbetsmarknadspolitik som finns i Norden se om länderna kan lära någonting av varandra. För att kunna göra det på ett bra sätt är det viktigt att ha en bild av hur ländernas arbetsmarknad ser ut, hur arbetslöshet och sysselsättning utvecklats de senaste decennierna och hur mycket offentliga medel som går till arbetsmarknadspolitiken. För att göra det på ett jämförbart och rättvisande sätt används konsekvent data från OECD.

Internationellt talas det ofta om den nordiska modellen - en modell som sammanlänkar de nordiska länderna och dess välfärdssystem till en sammanhållen linje. Mycket förenar de nordiska länderna, exempelvis en förhållandevis stark offentlig sektor, en till stor del skattefinansierad ambitiös välfärd och familjepolitik. Dessa har även bidragit till kvinnors starka ställning på arbetsmarknaden i Norden, då den offentliga sektorn både erbjudit kvinnor arbetstillfällen och möjliggjort deras förvärvsarbete genom att organisera vård och omsorg för barn och äldre. Vidare förenas de nordiska länderna i en till stor del avtalsreglerad arbetsmarknad där sociala parter har stort inflytande och där det offentliga strävar efter tillväxt, hög sysselsättning och fördelningspolitik. Det finns samtidigt många olikheter när länderna granskas närmare. Följande avsnitt avser att genom användandet av internationellt jämförbar statistik från OECD samt Eurostat illustrera både skillnader och likheter i de nordiska ländernas arbetsmarknadssystem.

\subsection{Sysselsättningsgrad och arbetslöshet}

Sysselsättningsgraden mäter hur stor del av befolkningen i arbetsför ålder som är sysselsatt. Arbetsför ålder definieras enligt OECDs statistik som mellan 15-64 år. Sysselsättningsgraden påverkas bland annat av rådande konjunktur, funktionssätt och demografiska aspekter som åldersfördelning och andel av befolkningen som går vidare till högre studier. En ytterligare aspekt som kan påverka sysselsättningen, framför allt för kvinnor är system för exempelvis föräldraledighet, föräldraförsäkring och barnomsorg. Sysselsättningsgraden för de nordiska länderna samt snittet för OECD-länderna illustreras i figur 3 . 
Figur 3: Sysselsättningsgrad i procent

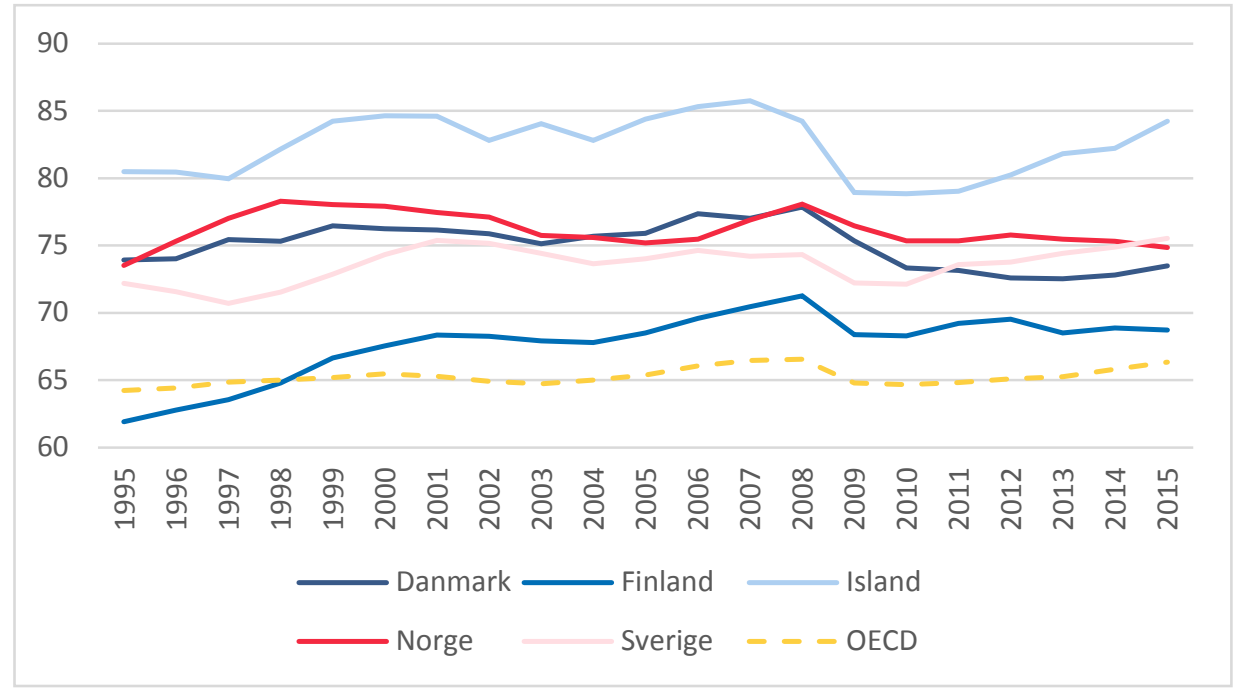

Sysselsättningsgraden har generellt varit mycket hög bland de nordiska länderna i förhållande till OECD. Av de nordiska länderna har Finland lägst sysselsättningsgrad. Denna låg under andra halvan av 1990-talet lägre än snittet för $O E C D$, men har sedan dess ökat med över fem procentenheter. Island, som är det land med högst sysselsättningsgrad i Norden har, liksom Finland, upplevt större förändringar i sysselsättningsgraden än resterande länder i Norden. Islands sysselsättningsgrad föll i samband med finanskrisen 2008 då landets arbetslöshet också steg dramatiskt. Innan den finansiella krisen hade Island en toppnotering på 85 procent i sysselsättningsgrad. Den föll snabbt till runt 77 procent i början av 2009. Danmark, Norge och Sverige har de senaste 20 åren sett likartade nivåer på sysselsättningsgrad kring 75 procent. 
Figur 4: Sysselsättningsgrad för kvinnor och män

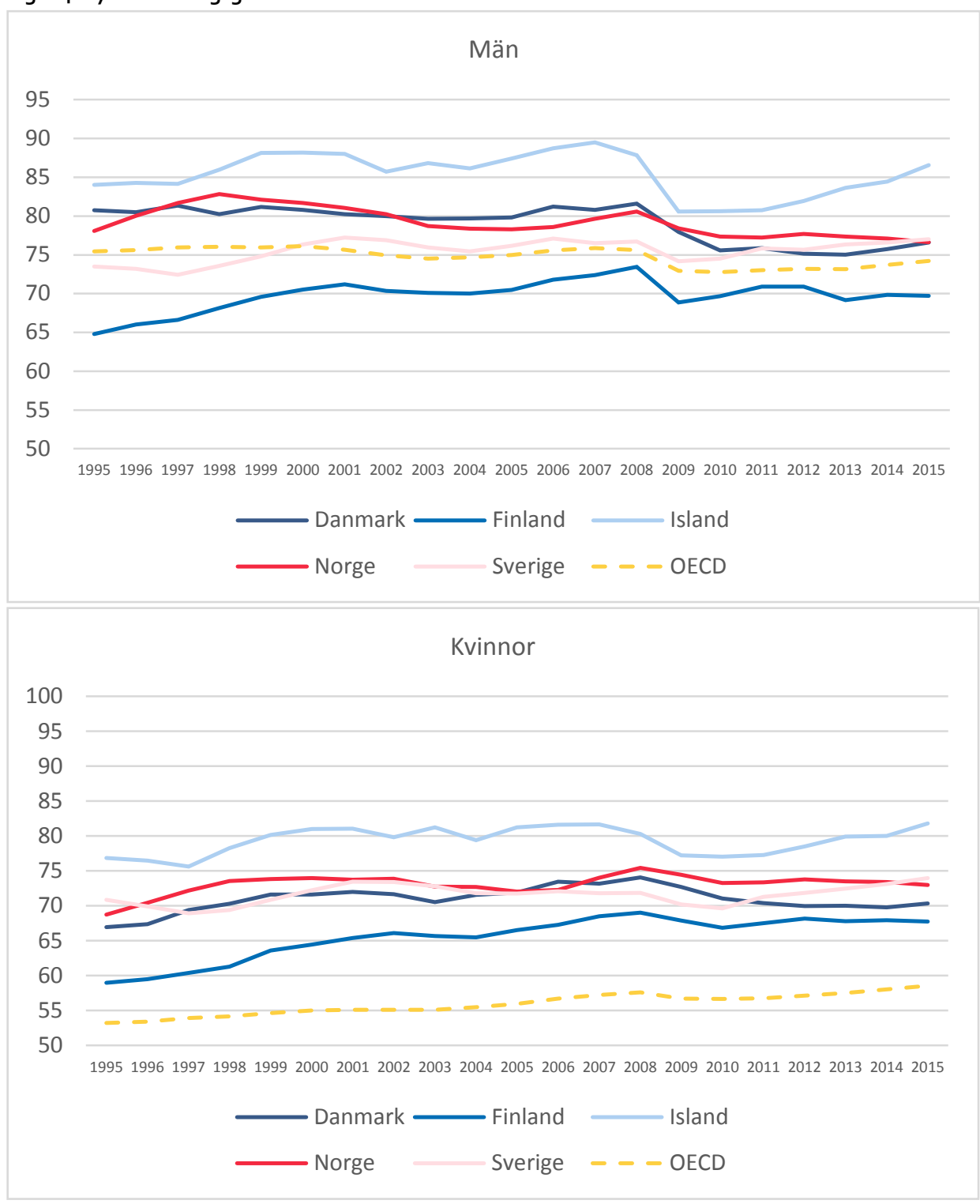

Figur 4 illustrerar sysselsättningsgraden för kvinnor respektive män under den senaste tjugoårsperioden för de nordiska länderna samt i genomsnitt för OECD. En tydlig trend som framträder är den betydligt högre sysselsättningsgraden för kvinnor i de nordiska länderna jämfört med genomsnittet för kvinnor i OECD. OECD har haft en 
genomsnittlig sysselsättningsgrad för kvinnor kring 55 procent medan de nordiska ländernas sysselsättningsgrad legat mellan 65 procent (Finland) och 80 procent (Island). En anledning till den stora skillnaden kan vara de generösa välfärdssystem som genomsyrar de nordiska länderna med t ex generös föräldraledighet och subventionerad barnomsorg, vilket leder till särskilt högt arbetskraftsdeltagande. Även skattesystemet påverkar kvinnors deltagande på arbetskraften, och då särskilt om individuell eller familjebeskattning tillämpas.

Finland uppvisar den lägsta sysselsättningsgraden för kvinnor, men även sysselsättningsgraden för män är den lägsta i Norden, och dessutom lägre än snittet i OECD. Finland har konsekvent haft en lägre sysselsättningsgrad än de resterande nordiska länderna det senaste decenniet. Detta kan delvis förklaras med landets konjunkturkänsliga näringslivsstruktur som gjorde att Finland drabbades hårt av finanskrisen 2008. Medlemskapet i eurozonen har inneburit att penningpolitiska åtgärder inte kunnat användas som botemedel, och EU-sanktionerna mot den viktiga ryska exportmarknaden har ytterligare försämrat situationen. Den ekonomiska konjunkturen är dock bara en av flera saker som kan tänkas påverka sysselsättningsläget.

Andra tänkbara faktorer som kan påverka arbetsmarknaden inkluderar bostadsmarknaden, migration, möjligheter till geografisk och professionell rörlighet, kulturella faktorer med mera.

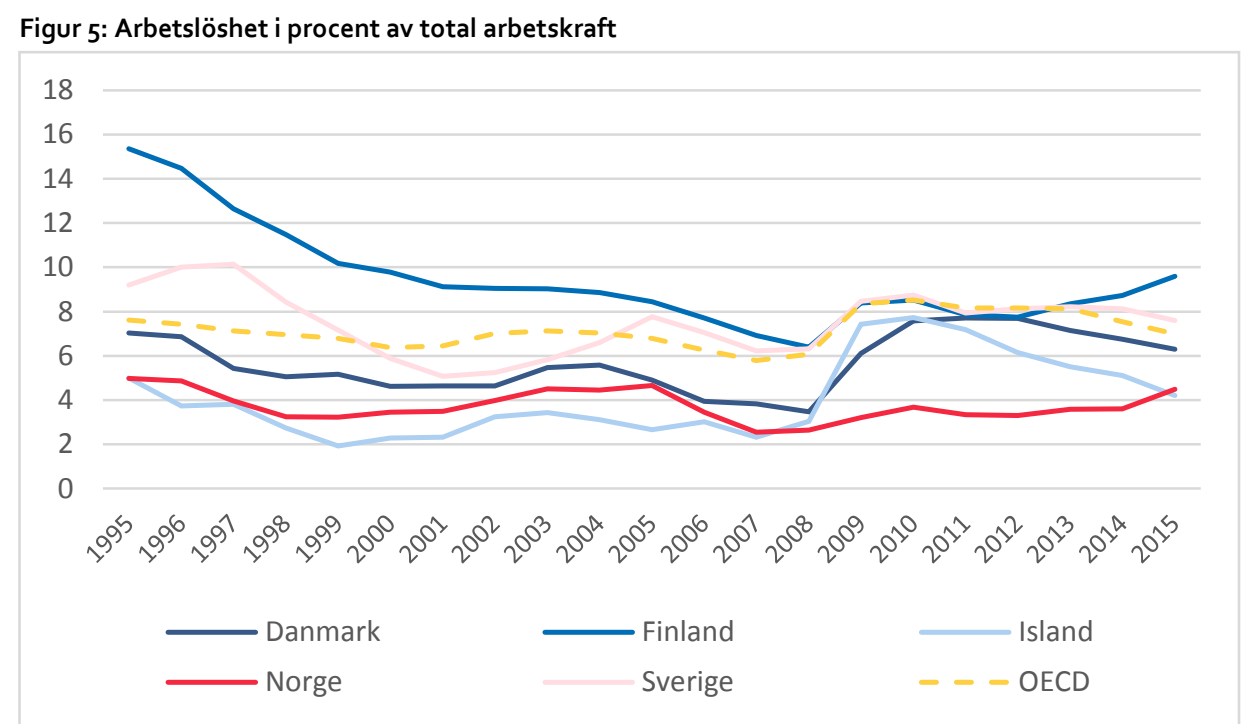

Kilde: OECD (2016) Unemployment rate. 
Generellt sett är sysselsättningsgraden för kvinnor något lägre än för män i alla de nordiska länderna. Skillnaden i sysselsättningsgrad är som lägst i Finland där skillnaden år 2014 uppgick till knappt två procentenheter och sysselsättningsgraden är relativt sett låg för både män och kvinnor. Skillnaden är störst i Danmark där den uppgick till sex procentenheter mellan kvinnors och mäns sysselsättningsgrad 2014, enligt OECD:s data. Dessa skillnader bör sättas i relation till snittet för OECD, där skillnaden i sysselsättningsgrad mellan män och kvinnor år 2014 uppgick till nästan 16 procentenheter. Året efter finanskrisen 2008 minskade sysselsättningsgraden mer bland män än bland kvinnor i alla nordiska länder, vilket också till viss del utjämnat skillnaderna i sysselsättningsgrad mellan män och kvinnor.

Trots att sysselsättningsgraden varit relativt stabil de senaste två decennierna i de nordiska länderna, med undantag för åren efter finanskrisen 2008, så har stora förändringar skett i arbetslösheten, också främst under åren efter finanskrisen. Arbetslösheten är här skattad som andel arbetslösa i relation till den totala arbetskraften (antal sysselsatta och arbetslösa) och är en av de viktigaste indikatorerna för ekonomins välmående. Arbetslös är den som saknar arbete, står till arbetsmarknadens förfogande samt aktivt sökt arbete de senaste fyra veckorna. Figur 5 illustrerar arbetslöshet i procent för de nordiska länderna samt snittet för OECD under tidsperioden 1995-2014.

Som en konsekvens av den djupa ekonomiska krisen som rådde i början av 1990talet hade flera av de nordiska länderna då en mycket hög arbetslöshet, som kom att minska under slutet av årtiondet och början på oo-talet. Framför allt Finland hade mycket hög arbetslöshet på uppåt 15 procent i mitten på go-talet. Därefter sjönk den gradvis för att 2008 vara nere på samma nivåer som Sverige och OECD. Sverige såg också stigande arbetslöshet i början på go-talet som ett resultat av krisen i början av go-talet, men hade en fallande trend i slutet av årtiondet. I jämförelse med Finland som haft en jämn minskning av arbetslösheten fram till finanskrisen såg Sverige ytterligare en uppgång under 2003-2005 pga. svängningar i konjunkturen. Finland och Sverige skiljer sig från resterande nordiska länder som haft en betydligt mer stabil arbetslöshetsutveckling sedan mitten av go-talet. Både Island och Norge har haft mycket låg arbetslöshet med nivåer mellan 2 och 4 procent, medan Danmark har legat något högre. Alla nordiska länder, med undantag för Norge, fick kraftigt stigande arbetslöshet när finanskrisen gjorde avtryck på arbetsmarknaden 2009.

I och med finanskrisen 2008 ändrades förhållandet i arbetslöshet mellan män och kvinnor. I alla nordiska länder var det männen som drabbades hårdast när arbetslösheten ökade. En förklaring till dessa skillnader är delvis på grund av att industrin och byggbranschen, två mansdominerande branscher, drabbades hårt av krisen. Offentlig verksamhet, där kvinnodominerande yrken ofta återfinns, drabbades först något se- 
nare av krisen. Arbetslösheten tenderar även att inte stiga lika drastiskt vid konjunkturnedgångar inom offentlig sektor som privat.

\subsubsection{Långtidsarbetslöshet och tid utan arbete}

Ett relaterat mått är långtidsarbetslöshet. I OECDs internationella statistik är långtidsarbetslöshet skattat som den andel arbetssökande som varit utan jobb och aktivt sökt arbete i minst tolv månader i relation till det totala antalet arbetslösa. Långtidsarbetslösheten för de nordiska länderna samt snittet för OECD de senaste 20 åren är illustrerad i figur 6. Långtidsarbetslöshet ökar ofta i en konjunkturnedgång då antalet arbetslösa ökar och antalet vakanser sjunker, vilket leder till att arbetslöshetstiderna ökar. Trots att arbetslösheten minskade i de nordiska länderna innan finanskrisen 2008 har utvecklingen av långtidsarbetslöshet inte varit lika jämn. För det första uppvisar de nordiska länderna stora skillnader i nivå av långtidsarbetslöshet men också i förändringar över tid. Den djupa ekonomiska krisen som rådde i början på go-talet bidrog till höga nivåer på långtidsarbetslösheten i främst Finland, Norge och Sverige. Generellt har de nordiska länderna i de flesta fall haft lägre långtidsarbetslöshet än snittet i OECD under den senaste 20-årsperioden.

Figur 6: Långtidsarbetslöshet i procent av total arbetslöshet

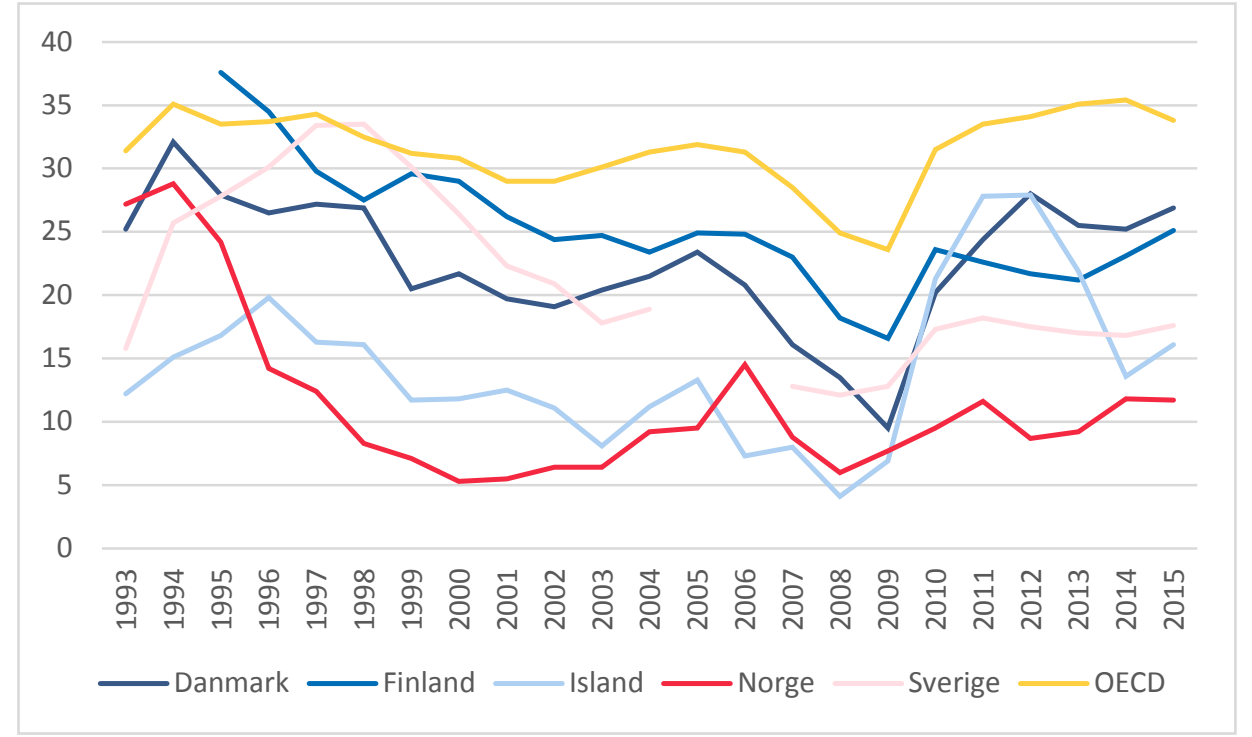

Note: Anm. uppgifter om Sveriges långtidsarbetslöshet 2005-2006 är inte rappor-terade i OECDs databas. 
De stora skillnaderna i långtidsarbetslöshet vittnar om en diskrepans mellan de nordiska länderna vad gäller effektivitet i matchningen på arbetsmarknaden. Höga nivåer av långtidsarbetslöshet kan vara ett tecken på att arbetsmarknaden inte på ett effektivt sätt kan hantera problematiken med förlorat humankapital efter en längre tids arbetslöshet. En orsak till stora skillnader i långtidsarbetslöshet kan vara olikheter i arbetskraftens sammansättning. Om arbetskraften till en stor del består av individer med svag anknytning till arbetsmarknaden, exempelvis nyanlända utan arbetslivserfarenhet i det nya landet, kommer matchningsfunktionen att försämras, arbetslöshetstiderna att öka varpå långtidsarbetslösheten stiger. Figur 7 illustrerar arbetslöshetstider för 2014 för de nordiska länderna samt snittet för OECD. Figur 7 illustrerar hur många procent av alla arbetslöshetsperioder som 2014 var kortare än en månad, mellan en och tre månader, mellan tre och sex månader, mellan sex och tolv månader eller längre än tolv månader. Genom att jämföra hur snabbt arbetslösa kommer tillbaka ut i arbete igen går det att skapa sig en uppfattning om hur effektiv matchningsprocessen är på de respektive arbetsmarknaderna. Enligt arbetslöshetstiderna under 2014 var Island, Norge och Sverige snäppet bättre på att få till snabba matchningsprocesser. Ca 50 procent av alla arbetslöshetsperioder på Island, i Norge och i Sverige var kortare än tre månader. I Danmark, Finland samt OECD var motsvarande siffra 40 procent.

Figur 7: Arbetslöshetstider 2014

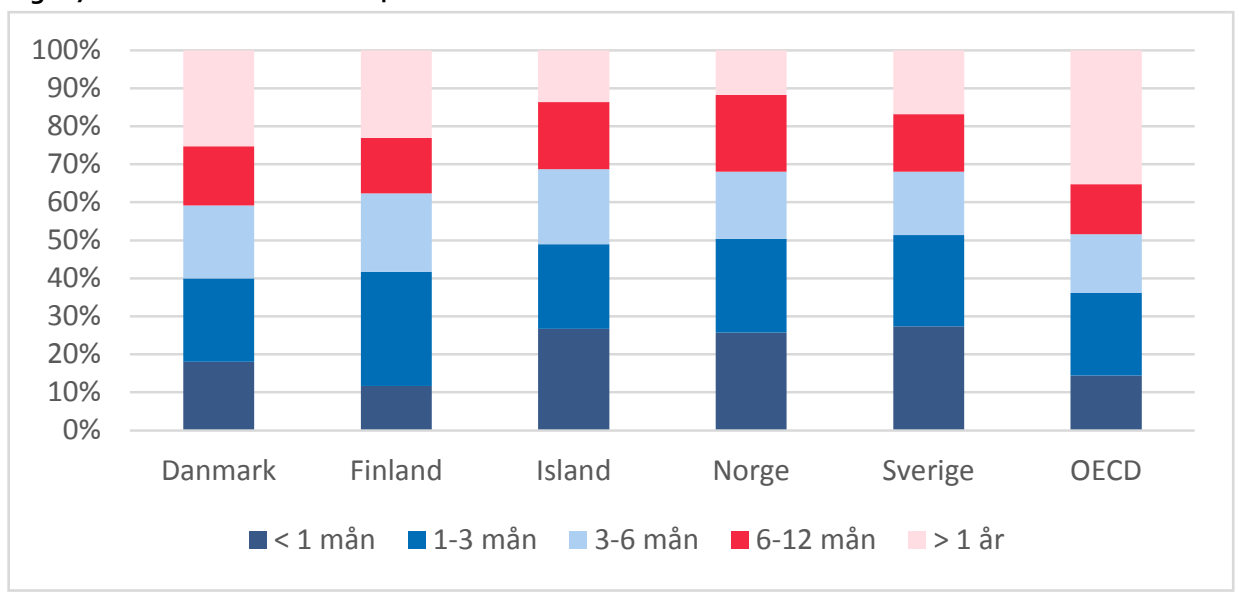


En förklaring till skillnader $\mathrm{i}$ arbetslöshet och arbetslöshetstider mellan individer är bland annat utbildning. Det är naturligt att arbetsmarknadsutsikter och arbetslöshet skiljer sig åt beroende på utbildningsbakgrund hos individer på arbetsmarknaden. Det finns oftast ett positivt samband mellan utbildning och arbetsmarknadsutsikter där en individ med högre utbildning premieras på arbetsmarknaden. Detta går tydligt att utläsa ur figur 8 som illustrerar arbetslöshet uppdelat på tre olika utbildningsnivåer; grundskole-, gymnasie- och universitets-/högskoleutbildning för det senaste decenniet. Arbetslösheten var och är högst för de som enbart har en grundskoleutbildning oavsett nordiskt land. De med enbart grundskoleutbildning har också generellt sett blivit hårdast drabbade av finanskrisens efterdyningar och det finns en tydligt ökande trend $\mathrm{i}$ arbetslöshetsutvecklingen för de lågutbildade $\mathrm{i}$ alla nordiska länder. Finland och Sverige har den högsta arbetslösheten bland de med grundskoleutbildning och arbetslösheten bland dessa individer har även fortsatt öka på senare år. Danmark och Island har istället lyckats vända trenden med ökande arbetslöshet för de med kortast utbildning och såg en avtagande trend under 2012 och 2013. 
Figur 8: Arbetslöshet uppdelat på utbildningsnivå

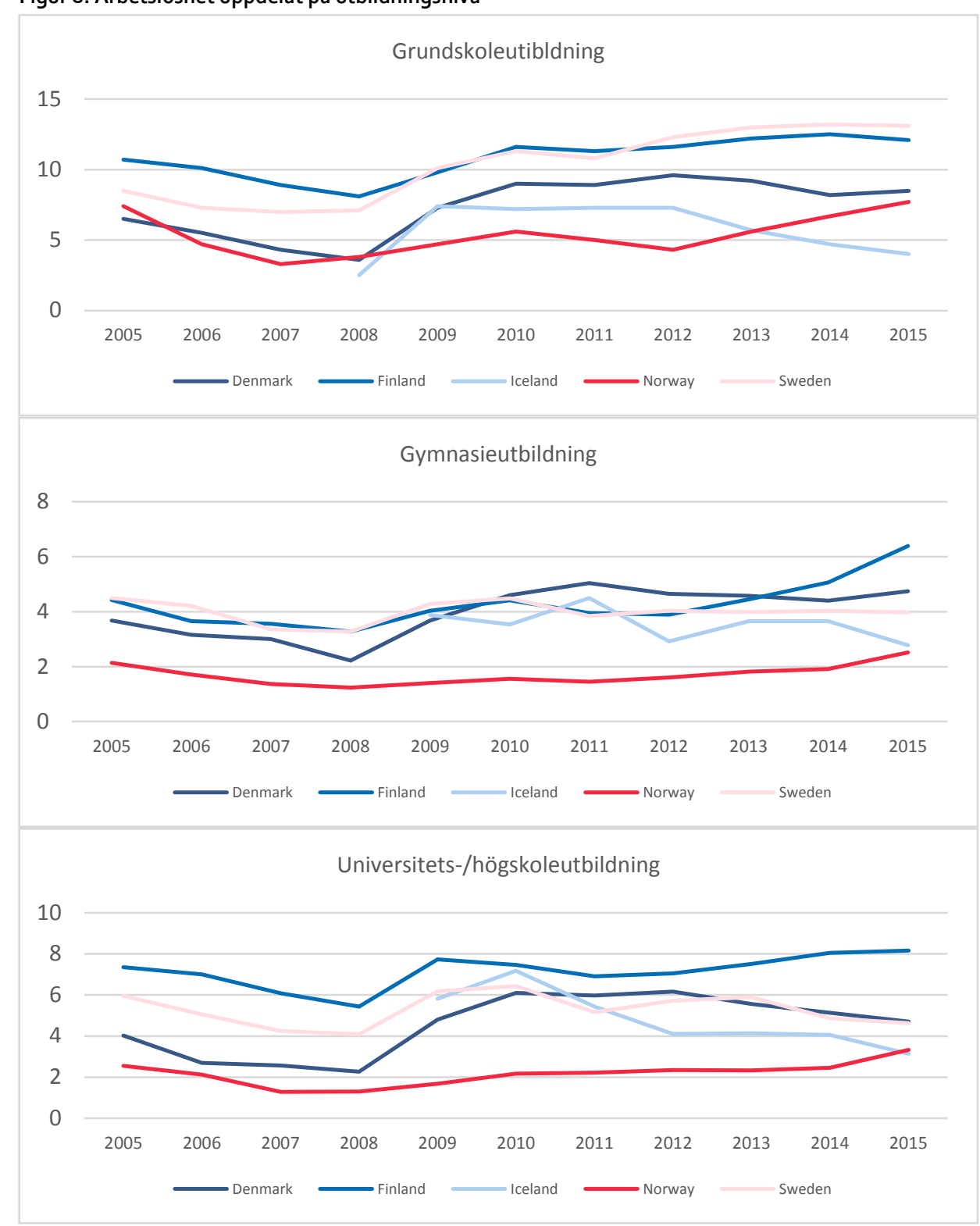

Note: Anm. Tidsspannet för arbetslöshet uppdelat på utbildning sträcker sig från 2005 istället för 1995 pga bristande statistik innan 2005 i OECDs databas. 
Arbetslösheten faller tydligt med utbildningsgrad, vilket illustreras i figur 8. Individer med universitets-/högskoleutbildning upplever den lägsta arbetslösheten och de med enbart grundskoleutbildning upplever den högsta. Utmärkande för Norge är att finanskrisen 2008 inte verkar haft någon större inverkan på dem med högre utbildningsnivåer utan det var främst personer med högst grundskoleutbildning som drabbades av högre arbetslöshet.

\subsubsection{NEETs}

Ett vanligt förekommande mått av arbetslöshet är arbetslöshet uppdelat på olika åldersgrupper. Arbetslösheten brukar vara högst bland de unga i samhället då de ofta står längre från arbetsmarknaden än de redan etablerade och möter en tröskel när de ska komma in på arbetsmarknaden. Att studera arbetslöshet för gruppen ungdomar är dock problematiskt av flera anledningar. ${ }^{16}$ Ett bättre mått för att mäta arbetslöshet och inaktivitet i den aktuella åldersgruppen är att använda sig av andel unga som varken arbetar eller studerar, NEET (Not in employment, education or training). NEET mäter hur stor andel av alla ungdomar i den aktuella åldersgruppen som varken jobbar eller studerar. Även om denna grupp kan innehålla ungdomar som är ute och reser, eller studerar eller arbetar i ett annat land än det de är skrivna i, är de flesta ungdomar i denna grupp personer med svagare arbetsmarknadsanknytning. Med detta mått återfås således en mer rättvis bild av de ungdomar som kräver extra åtgärder för att komma in på arbetsmarknaden eller i utbildningssystemet. Figur 9 illustrerar NEET för de nordiska länderna samt OECD för det senaste decenniet. Notera att OECDs statistik, som presenterats i figur 9, är åldersgruppen 15-24 uppdelad i två separata grupper. Den första åldersgruppen, 15-19 år, går fortfarande i skolan, motsvarande gymnasienivå.

\footnotetext{
${ }^{16}$ I åldersgruppen 15-19 är de flesta ungdomar heltidsstuderande på gymnasienivå. I den något äldre gruppen 20-24 är istället många ungdomar hel- eller deltidsstuderande på universitet eller högskola. Detta är i sig inget problem då studerande ungdomar inte räknas som arbetslösa. Dock söker många ungdomar extrajobb vid sidan av sina studier vilket gör att ungdomar som är heltidsstuderande räknas in i arbetslöshetsstatistiken. Ett mått på hur hög arbetslösheten är för åldersgruppen 15-24 kan då ge en mycket missvisande bild över hur arbetslösheten egentligen ser ut för just denna åldersgrupp.
} 
Figur 9: Andel unga (mellan 15-19 och 20-24 år) som varken arbetar eller studerar (NEET)

Åldersgrupp $15-19$

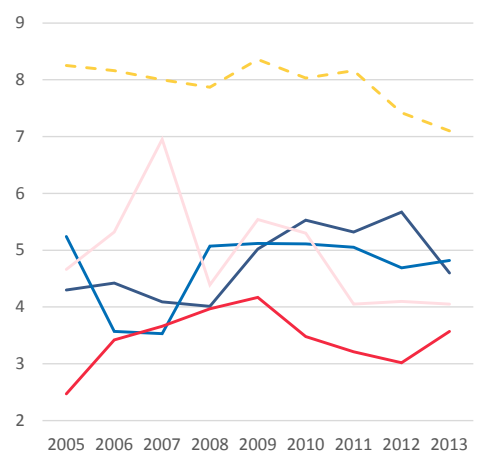

200520062007200820092010201120122013
Åldersgrupp 20 - 24

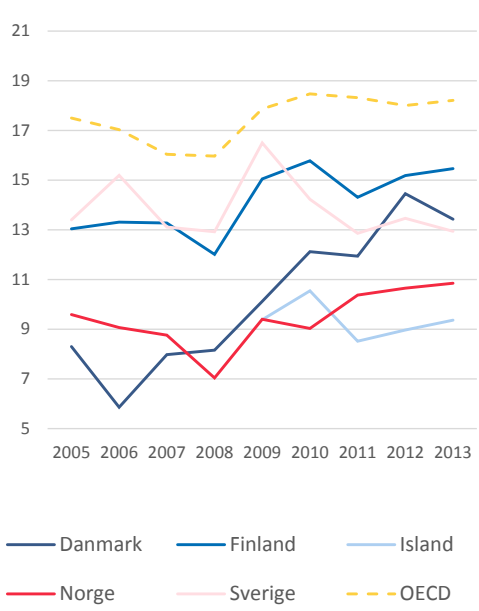

Note: Anm. statistik för Island finns inte för åldersgruppen 15-19 år samt innan 2009 för åldersgruppen 20-24.

Utmärkande enligt statistiken över NEET, som illustrerats i figur 9, är att OECD-snittet ligger betydligt högre än talen för de nordiska länderna för båda åldersgrupperna. En annan tydlig trend är att NEET är betydligt lägre för den yngre åldersgruppen i samtliga länder. Det förklaras till stor del av att de flesta ungdomar fortfarande är kvar i utbildning i den åldern. En annan förklaring för en lägre NEET bland de yngre är också ett denna målgrupp i bl.a. Finland och Sverige omfattas av ett större samhällsansvar, där alla unga i jobbgarantin för unga som slutfört den grundläggande utbildningen garanteras en studieplats eller anställning. Även om de nordiska länderna uppvisar skillnader i NEET för den yngre gruppen var det 2013 en relativt entydig bild i Norden jämfört med OECD. NEET låg mellan 3,5 procent och strax under 5 procent i Norden 2013, medan snittet för OECD låg på strax över 7 procent.

En betydligt större spridning samt större variation över tid uppvisar den äldre åldersgruppen, individer mellan 20-24 år. Här utmärker sig Danmark som ett undantag bland de nordiska länderna. Från att i mitten av oo-talet haft lägst andel NEET i Norden har Danmark nu den näst högsta andelen efter Finland, en ökning med strax under tio procentenheter. Noterbart är även att alla länder, med undantag för Island, har en NEET-andel på över 10 procent 2013. Detta är lägre än snittet för OECD visserligen, 
men att över 10 procent av alla i åldersgruppen 20-24 står utanför både utbildning och arbetsmarknad ger en indikation på hur svårt det kan vara att etablera sig som ung på arbetsmarknaden även i de nordiska länderna.

\subsection{Offentliga utgifter för arbetsmarknadspolitik}

Arbetsmarknaderna i de nordiska länderna har både likheter och olikheter i sysselsättning, arbetslöshet samt förekomst av deltidsarbete och tidsbegränsade kontrakt. Det råder även skillnader i arbetsmarknadspolitisk inriktning länderna emellan som blir tydliga vid närmare granskning av ländernas offentliga utgifter för arbetsmarknadspolitiska åtgärder. I figur 10 illustreras de offentliga utgifterna för arbetsmarknadspolitiken i procent av BNP under de senaste 20 åren. De offentliga utgifterna är uppdelade i aktiva åtgärder och passiva åtgärder där de aktiva åtgärderna avser åtgärder som är inriktade på matchning, utbud eller efterfrågan på arbetsmarknaden som exempelvis arbetsförmedling, omskolning och subventionerad sysselsättning, medan de passiva åtgärderna avser inkomstersättning till arbetslösa som exempelvis arbetslöshetsersättning och inkomstförsäkringar. Det bör dock påpekas att OECDs uppgifter om offentliga utgifter för arbetsmarknadspolitik inte ger en komplett bild av de offentliga kostnaderna för arbetsmarknadspolitiken. Som nedan påvisas bär kommunerna i de nordiska länderna en betydande del av de faktiska kostnaderna, även om dessa inte faller inom ramen för den statliga arbetsmarknadspolitiken. Dels bedriver kommunerna i vissa länder olika aktiva åtgärder parallellt med de statliga arbetsmarknadsåtgärderna (exempelvis i Finland och Sverige), dels bär framförallt kommunerna ofta kostnaderna för socialbidrag. Bland annat åtstramningar i arbetslöshetsförsäkringarna har under de senaste åren i flera nordiska länder lett till att socialbidrag i allt högre grad kommit att fungera som försörjningsstöd även för arbetssökande.

För Island finns ingen data för denna kategori av variabler i OECDs databas "Public spending on labour markets" (2016). För de länder som är representerade i figur 10 framgår ett tydligt mönster med två olika grupper. Den första består av Danmark och Finland, där utgifterna för passiva åtgärder har varit den dominerande utgiften de senaste 20 åren. Utgifterna för de passiva åtgärderna, alltså arbetslöshetsersättning till arbetslösa, har dock minskat i förhållande till BNP. Åtminstone för Finlands del överensstämmer den höga utgiftsandelen för passiva åtgärder med den höga arbetslöshet som rådde under 1990-talet. Samma mönster finns dock inte i Danmark under samma tidsperiod. De aktiva åtgärderna har istället utgjort en relativt konstant del av BNP under hela den studerade perioden. 
Den andra inriktningen är Norges och Sveriges större fokus på de aktiva åtgärderna. Norge utgör generellt ett undantag med betydligt lägre totala utgifter än resterande länder men bortsett från detta är trenden likartad den i Sverige. Norge och Sverige har sett minskade utgifter för de aktiva åtgärderna över tid, precis som Danmark och Finland haft minskade utgifter för de passiva. Endast under åren direkt efter finanskrisen 2008 ökade utgiftsandelen för de aktiva åtgärderna i Norge och Sverige.

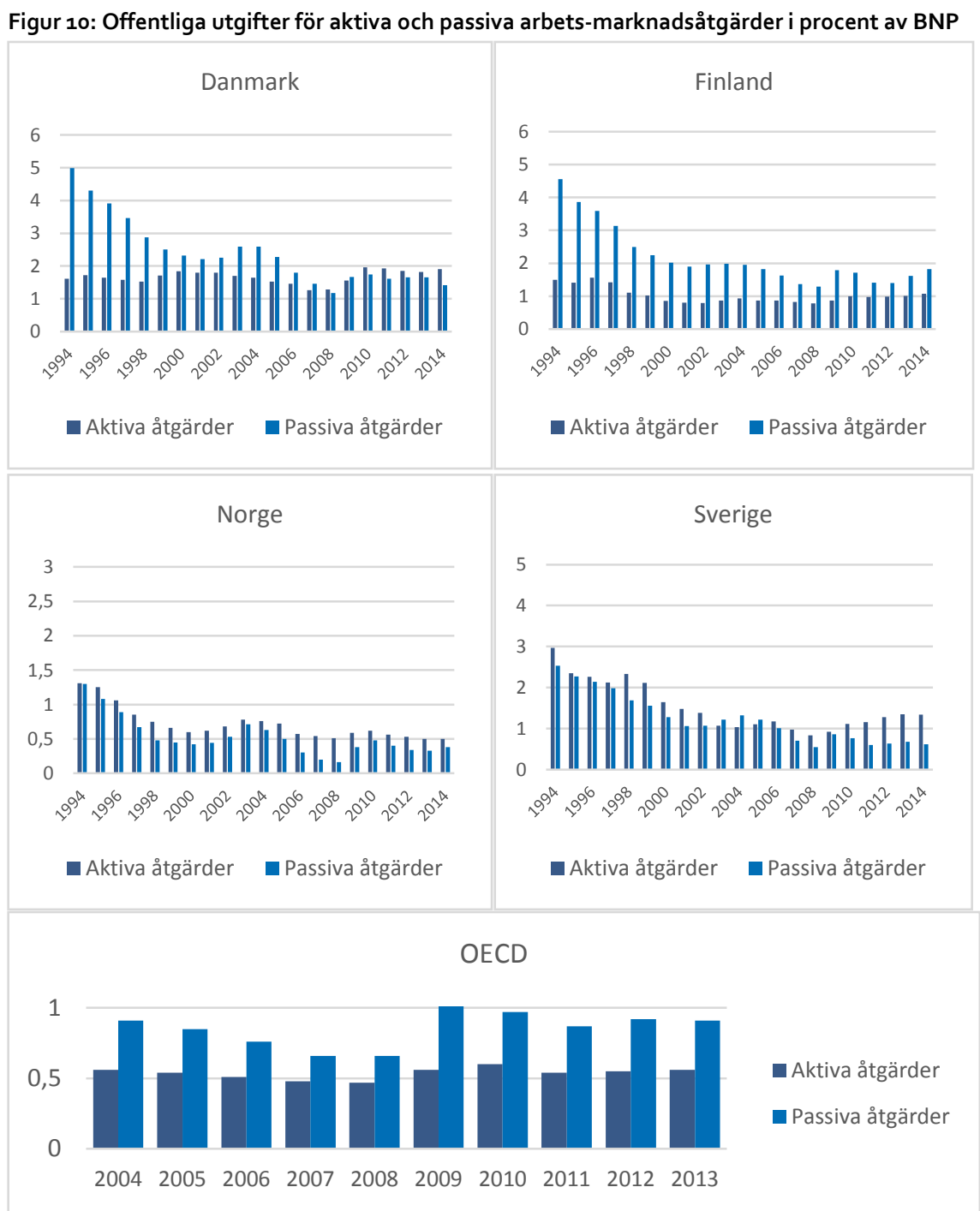

Note: Anm. statistik saknas för OECD-genomsnittet före 2004, samt för Island. 
En skillnad mellan Norge och Sverige är att båda länderna efter krisen hade en ökande trend 2013 minskade i Norge utgiftsandelen för de aktiva åtgärderna redan efter 2010.

Utvecklingen av de största utgiftsposterna för de aktiva och passiva åtgärderna samt utvecklingen för de totala offentliga utgifterna för arbetsmarknadspolitiken visas i figur 11. Det framgår tydligt vilken betydande roll arbetsmarknadspolitiken åtminstone tidigare har spelat för flera av de nordiska länderna jämfört med snittet för OECD. De totala utgiftsandelarna för arbetsmarknadspolitiken låg i början av 1990talet på betydligt högre nivåer för de flesta nordiska länder än de gör idag. Alla länder representerade i figur 11 har haft en stadigt avtagande trend för utgifterna i förhållande till BNP. Norge utgör återigen ett undantag med mindre än hälften så höga utgiftsandelar för arbetsmarknadspolitik än resterande länder. Väntat är även den ökning av totala utgifter som alla länder uppvisar efter finanskrisen 2008, även om Norges ökning var mycket blygsam jämfört med den i de länder som drabbades hårdare under krisen, t ex Danmark och Finland. 
Figur 11: Offentliga utgifter för arbetsmarknadspolitik uppdelat efter de största utgiftsposterna i procent av BNP

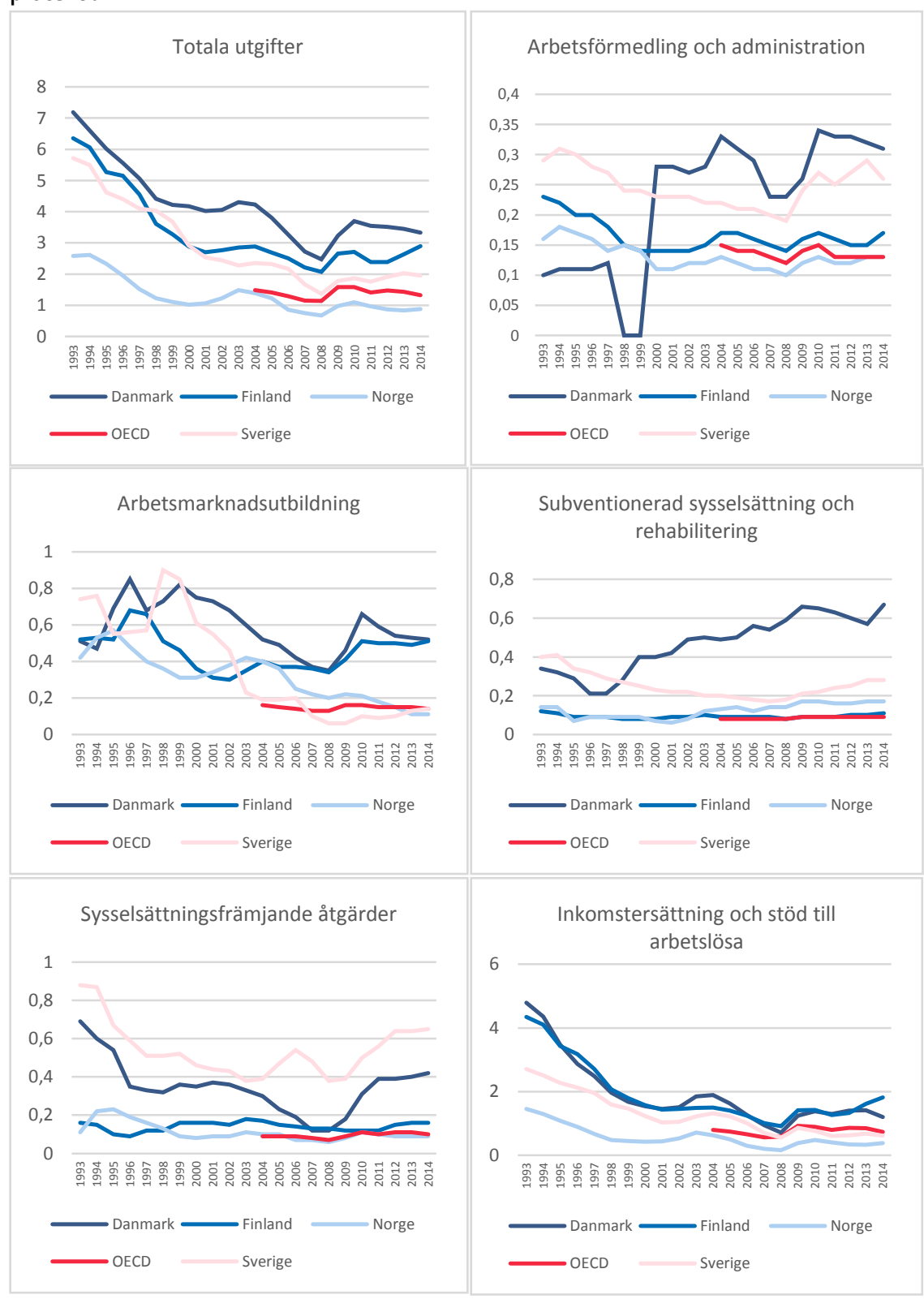

Note: Anm. statistik för Island samt statistik för OECD innan 2004 saknas i OECDs statistik över offentliga utgifter. 
Den tydligaste skillnaden mellan länderna återfinns i de aktiva åtgärderna, varav de fyra största är representerade i figur 11. Det framkommer också att stora förändringar har skett i dessa utgiftsposter under de senaste 20 åren. Exempelvis så har Danmark gått från höga utgifter för arbetsmarknadsutbildning i slutet på 1990-talet för att under 2000-talet satsat alltmer på arbetsförmedling och administration samt subventionerad sysselsättning och rehabilitering. Även Sverige har dragit ned sina utgifter för arbetsmarknadsutbildningen efter några år med höga volymer under 1990-talet. Finland har dock åter börjat investera i arbetsmarknadsutbildning sedan finanskrisen 2008 efter sänkta utgifter under flera år sedan go-talet.

Norge, som är det enda land som har haft en varaktig låg arbetslöshet och hög sysselsättning de senaste 20 åren, har även bland de lägsta utgifterna för alla utgiftsposter. Undantaget är för de subventionerad sysselsättning och rehabilitering som har ökat sedan början av 2000-talet, även om de fortfarande är på relativt låga nivåer.

För de passiva åtgärderna, inkomstersättning och stöd till arbetslösa, har trenden varit likartad i hela Norden. Från relativt höga utgiftsnivåer för inkomstersättning i början av 1990-talet så har utgifterna stadigt fallit för alla representerade länder. Ett undantag skedde när konjunkturen vände i början på oo-talet då utgifterna återigen steg som en effekt av ökad arbetslöshet och därmed uttag av inkomstersättning. Samma sak skedde i alla länderna efter finanskrisen men ingen av länderna har på senare år uppnått de nivåer som rådde på go-talet under den dåvarande rådande finansiella krisen. 


\section{Organisering av arbetsmarknadspolitik}

\section{1 Översikt över organisering i respektive land}

\subsection{Organisationsscheman}

Organiseringen av arbetsmarknadssystemen i de nordiska länderna illustreras i organisationsscheman för de olika länderna i figur 13-17. Figur 12 sammanfattar färgkodningen som används i ländernas organisationsscheman.

Figur 12: Färgkoder till figur 13-17.

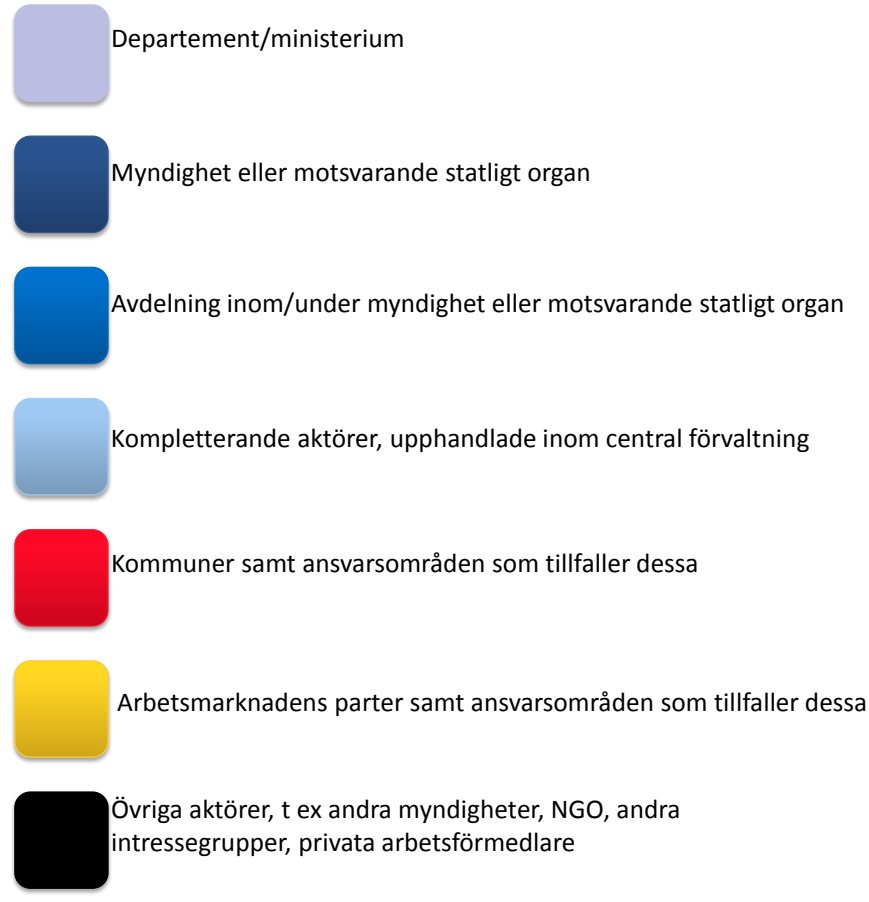


Figur 13: Organisationsschema Danmark

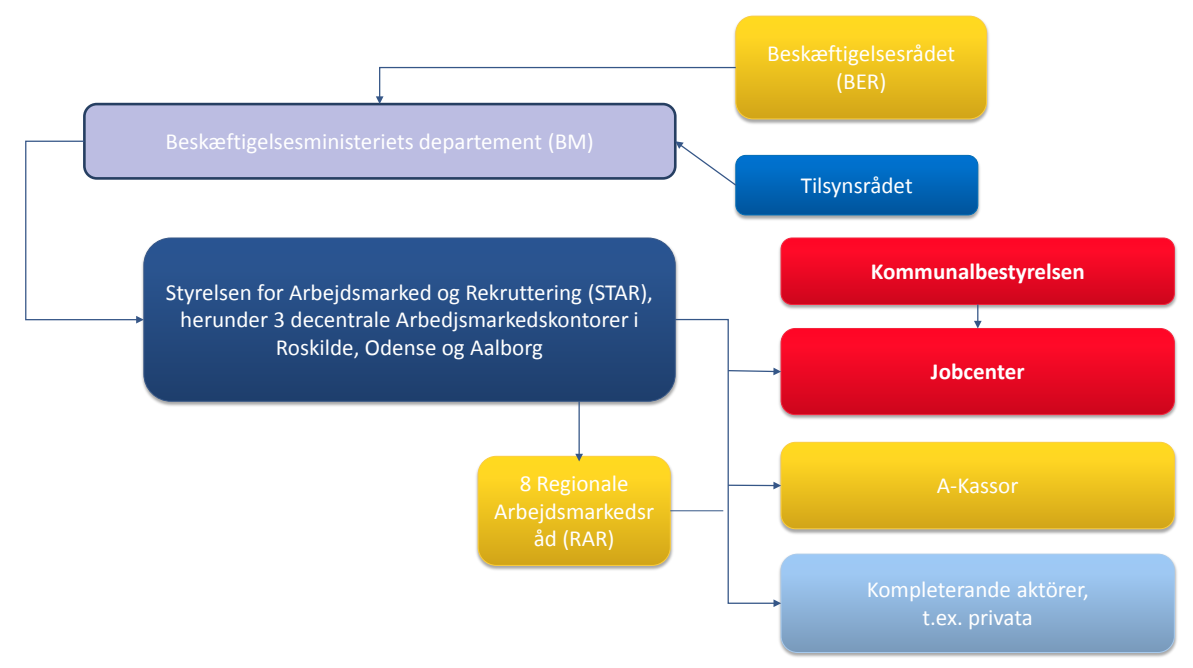

Figur 14: Organisationsschema Finland

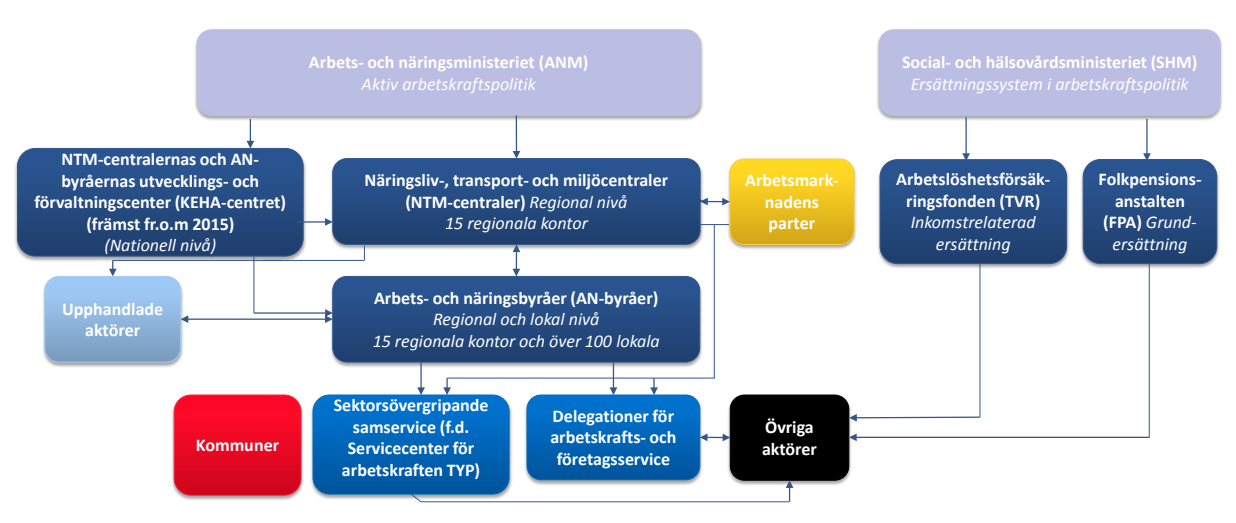


Figur 15: Organisationsschema Island

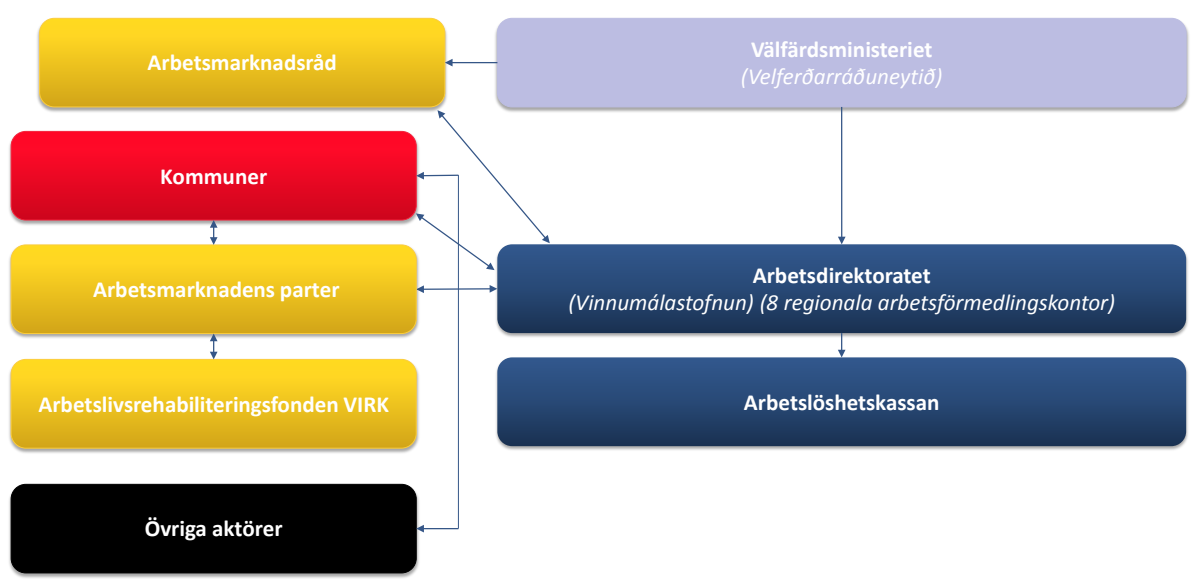

Figur 16: Organisationsschema Norge

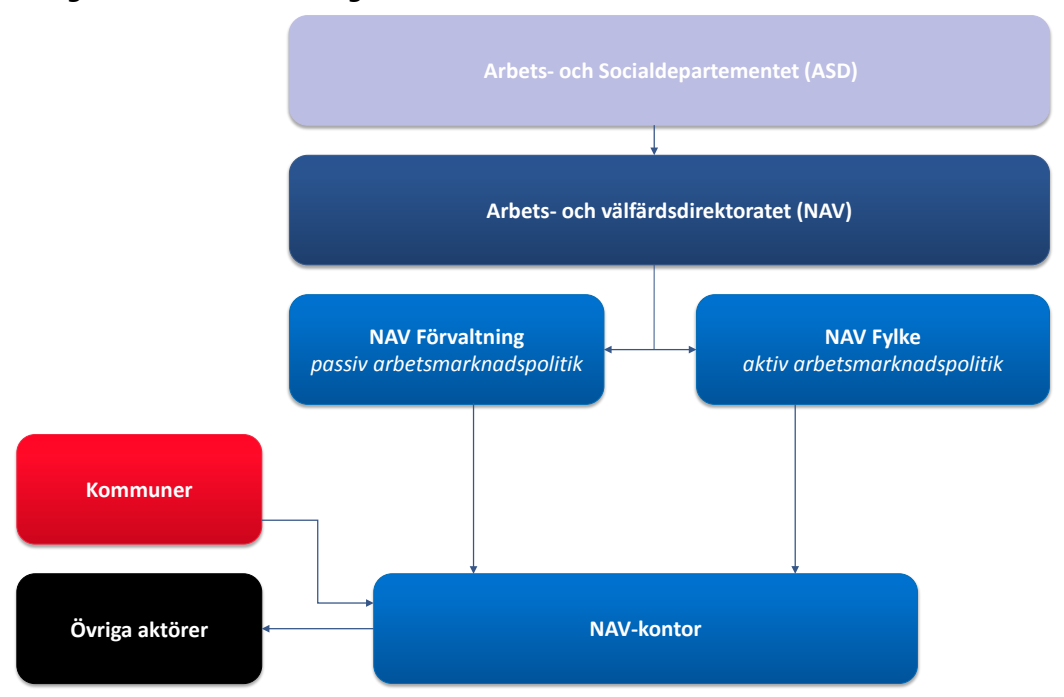


Figur 17: Organisationsschema Sverige

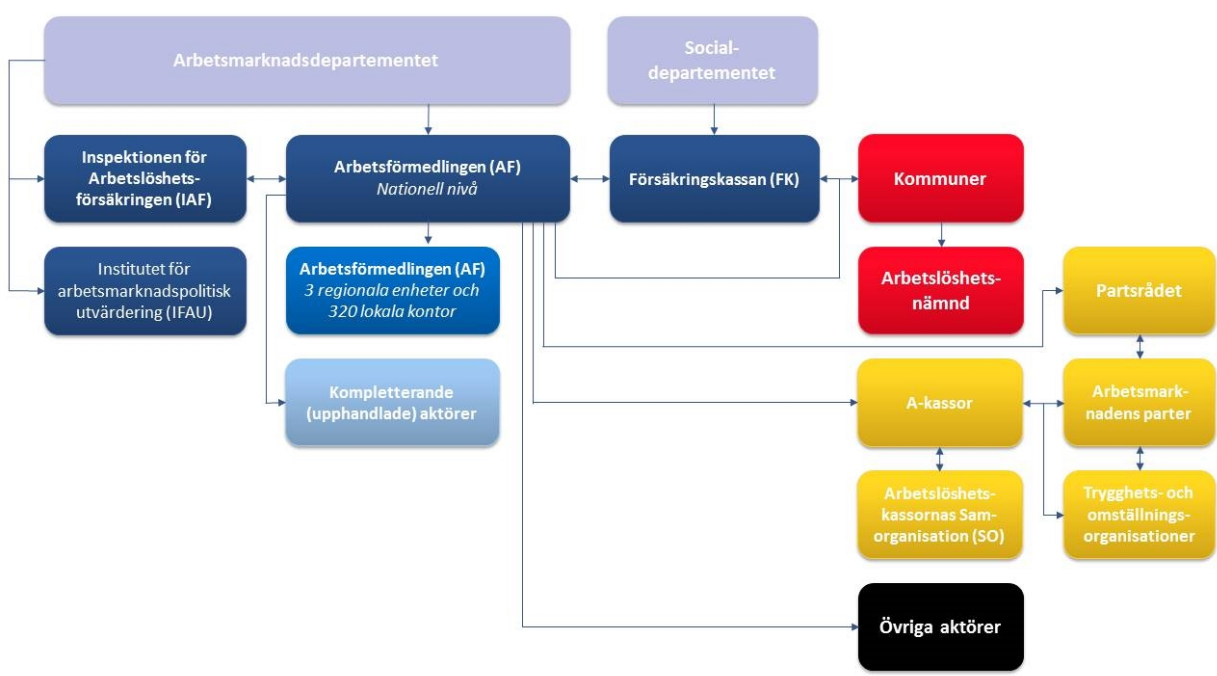

\subsection{Organisatoriska regimer i Norden}

Utifrån de organisationsscheman som presenterats för de nordiska ländernas arbetsmarknadssystem går det att urskilja en dominerande linje bland länderna i Norden. Huvudlinjen är en hierarkisk struktur där huvudansvaret för arbetsmarknadssystemet och politiken ligger på respektive lands arbetsmarknadsdepartement/ministerium där arbetsmarknadsministern har det yttersta ansvaret för utformningen av arbetsmarknadspolitiken. Detta gäller främst Danmark, Island och Norge där ansvaret ligger odelat på ett departement eller ministerium. Under arbetsmarknadsdepartementen är ansvaret för arbetsmarknadspolitiken delegerat till den myndighet som verkar inom arbetsmarknadsområdet i respektive land, vilket är Styrelsen för Arbetsmarknad och Rekrytering (STAR) i Danmark, Arbetsdirektoratet på Island och Arbets- och Välfärdsdirektoratet (NAV) i Norge. I organiseringen därunder skiljer sig länderna från varandra.

Island har en stark hierarkisk struktur där all arbetsmarknadspolitik bestäms av Välfärdsministeriet som delegerar det operativa arbetet den statliga arbetsförmedlingen (Arbejdsdirektoratet) samt den av Arbetsförmedlingen administrerade Arbetslöshetskassan. Kommunerna har ett ansvar på regional nivå men detta i samarbete med och under instruktioner och förordningar från ministeriet. Utöver detta skapas frekvent inofficiella och officiella samarbetskonstellationer, exempelvis mellan ministeriet och kommuner eller ministeriet och arbetsmarknadens parter. Arbetsmarknadens parter har en 
betydande roll på Island genom bildandet av Arbetslivsrehabiliteringsfonden (VIRK) där VIRK har översyn över all yrkesrehabilitering på Island. Arbetsmarknadens parter blir också tillfrågade att uttrycka sin åsikt i arbetsmarknadspolitiska ärenden till Välfärdsministeriet. Det innebär att alla arbetsmarknadsrelaterade frågor behandlas i trepartskonstellationer där arbetsmarknadens parter alltid ingår som part.

I Danmark har Beskæftigelsesministeriet samt STAR ansvaret för arbetsmarknadspolitiken. Själva arbetsförmedlingen är dock delegerad till kommunerna och inte till en centralt administrerad arbetsförmedling som fallet är i resten av Norden (förutom Färöarna och Grönland, se kapitel sex). Även administrering och utbetalning av arbetslöshetsförsäkringen är delegerad till 25 erkända arbetslöshetskassor (A-kassor) som ofta är anknutna till fackföreningar ${ }^{17}$ med frivilligt medlemskap enligt Gent-systemet. ${ }^{18}$ Detta innebär att STAR i Danmark har en mindre operativ roll inom arbetsmarknadspolitiken än exempelvis motsvarande myndighet på Island. Även i Danmark är arbetsmarknadens parter med i arbetsmarknadspolitiken, kanske främst genom systemet med självständiga A-kassor, men också genom att arbetsmarknadens parter tillsammans bildar ett Beskæftigelsesrådet (BER) som på nationell nivå agerar rådgivande till Beskæftigelsesministeriet och STAR i frågor kring arbetsmarknadspolitiken. Det har dessutom hänt att regeringen kallar samman till trepartsförhandlingar om reformer kopplade till arbetsmarknadspolitiken (vilket är mer vanligt i Finland, se nedan). Sammantaget framstår Danmark som mindre toppstyrt än Island inom arbetsmarknadspolitiken.

Norge, som också har ett styrande departement inom arbetsmarknadspolitiken, Arbets- och Socialdepartementet (ASD), skiljer sig från resterande nordiska länder i avseendet att arbetsmarknadspolitiken i allt väsentligt är samlat i en myndighet, NAV. Ansvarig myndighet under ASD är NAV. Vidare är NAV Fylke ansvarig instans för den aktiva arbetsmarknadspolitiken inklusive arbetsförmedlingen med tillhörande NAVkontor som drivs i samverkan med kommunerna. NAV Förvaltning ansvarar för den passiva arbetsmarknadspolitiken som arbetslöshetsersättning. NAV-kontoren är dock de som följer upp arbetslöshetsförsäkringen, ställer krav på den arbetssökande och har kontakt med individen. Det är dock NAV Förvaltning som fattar beslut. En arbetslös kommer i regel bara i kontakt med NAV Fylke genom de lokala NAV-kontoren medan NAV Förvaltning inte har någon direktkontakt med den arbetslösa. På detta vis har Norge den mest strömlinjeformade organisationen av arbetsmarknadspolitiken. Även om det formella ansvaret är delat mellan stat och kommun är servicen samlokaliserad och den arbetssökande möter i praktiken en myndighet.

\footnotetext{
${ }^{17}$ Notera dock att det I flera länder går att ansluta sig till arbetslöshetsförsäkringar utan att vara medlem I fackförening, och att det finns enstaka arbetslöshetsförsäkringar som ej är kopplade till fackföreningar.

${ }^{18}$ See http://www.oxfordreference.com/view/10.1093/oi/authority.20110803095850580
} 
I Finland är arbetsmarknadspolitiken uppdelad mellan två departement, varav Arbets- och Näringsministeriet (ANM) har ansvaret för den aktiva arbetsmarknadspolitiken och Social- och Hälsovårdsministeriet (SHM) för socialförsäkringssystemet (pensions-, sjuk- och arbetslöshetsförsäkring). Finland har alltså separerat ansvaret för aktiv arbetskraftspolitik och ersättningssystem redan på departementsnivå. Under SHM är systemet för arbetslöshetsersättningen uppdelad mellan två olika myndigheter. Arbetslöshetsförsäkringsfonden är ansvarig för den inkomstrelaterade arbetslöshetsersättningen som kräver medlemskap $i$ en arbetslöshetsfond medan Folkpensionsanstalten ansvarar för utbetalningen av grundersättningen som finns tillgänglig när den arbetslöse inte är berättigad till inkomstrelaterad ersättning. I Finland ligger ansvaret för politiken på ministerierna medan det operativa genomförandet är delegerat till regionala arbetsoch näringsbyråer (AN-byråer). Även de regionala Närings-, trafik- och miljöcentralerna (NTM-centralerna) har en roll inom arbetsmarknadspolitiken. Dessa regionala NTMcentraler har som uppgift att på bred front främja den regionala utvecklingen genom att sköta statsförvaltningens uppgifter och utveckling i regionerna. ${ }^{19}$ Inom arbetsmarknadspolitiken är deras roll att stödja och övervaka AN-byråerna i arbetet med att uppnå sina mål och i utvecklingen av tjänsterna. I praktiken är deras styrande roll gentemot AN-byråerna främst kopplad till budget, då NTM-centralerna fastslår hur det statliga anslaget för sysselsättnings- och företagsamhetspolitik ska fördelas mellan AN-byrån och NTM-centralen. Även resultatstyrningen går formellt via NTM-centralen, men de mål som på ministerienivå sätts upp för den regionala arbetsmarknadspolitiken vidareförmedlas i praktiken direkt till AN-byråerna. Även NTM-centralernas och AN-byråernas utvecklings- och förvaltningscenter KEHA har på ett praktiskt plan en roll i styrningen av AN-centralerna, då dessa gör upp riktlinjer kring diverse förvaltningsprocesser. KEHA är en relativt ny funktion i styrningen och hade tidigare ingen tydlig roll i arbetsmarknadspolitikens styrning.

AN-byråerna styrs därmed delvis direkt av ministeriet, delvis av NTM-centralerna och delvis av KEHA-centret. I Finland råder även ett relativt stort inkluderande av arbetsmarknadens parter. ${ }^{20}$ Styrkedjan till de lokala arbetsförmedlingskontoren är därmed mer komplex i Finland än något annat nordiskt land.

I Sverige ligger huvudansvaret för arbetsmarknad- och integrationsfrågor på Arbetsmarknadsdepartementet som bland annat förbereder lagstiftning på områ-

\footnotetext{
${ }^{19}$ Påminner således om länsstyrelserna I Sverige.

${ }^{20}$ På central nivå har parterna inflytande över med arbetslöshetsfonderna, som följer samma system som i både Danmark och Sverige. Arbetsmarknadens parter har ofta också varit aktivt delaktiga i arbetsgrupper kring arbetsmarknadspolitiken utformning på ministerienivå, men sedan regeringsskiftet 2015 kan man skönja en trend där arbetsmarknadens parter fått en mer passiv, närmast konsultativ roll. Även på lokal nivå sker samarbete med arbetsmarknadens parter, liksom med kommuner, utbildningsanstalter och upphandlade aktörer.
} 
det, budget- och styrningsfrågor samt har ansvaret för både den aktiva och den passiva arbetsmarknadspolitiken. Arbetsmarknadsdepartementet styr den underliggande myndigheten Arbetsförmedlingen (AF) som svarar för den offentliga arbetsförmedlingen samt dess arbetsmarknadspolitiska verksamhet. AF verkar både på nationell och regional och lokal nivå med lokala arbetsförmedlingskontor runt om i landet. Inom ersättningssystemen kopplade till arbetsmarknadspolitiken har Socialdepartementet en viss roll som ansvarigt departement för ekonomiskt stöd, som kommuner är utbetalande myndighet för. Arbetsmarknadsdepartementet har ansvar för de aktivitetsstöd och utvecklingsersättning som arbetslösa inom arbetsmarknadspolitiska program kan erhålla via Försäkringskassan istället för arbetslöshetsersättning (A-kassa). A-kassan i Sverige är organiserad enligt Gentsystemet med fristående arbetslöshetskassor knutna till fackföreningar där medlemskap i dessa arbetslöshetskassor är frivilligt (och frikopplat från medlemskap i fackföreningen). A-kassorna ansvarar för administration och utbetalning av arbetslöshetsersättningen, medan Arbetsförmedlingen har som skyldighet att säkerställa att den arbetslöse fullföljer sina åtaganden för att vara berättigad till ersättning från arbetslöshetsförsäkringen. För att säkerställa att arbetslöshetsförsäkringen fungerar som en omställningsförsäkring finns en särskild myndighet för att utföra inspektion av arbetslöshetsförsäkringen, nämligen Inspektionen för Arbetslöshetsförsäkringen (IAF). Utöver denna myndighet särskiljer sig Sverige från resterande Norden genom att också ha en särskild myndighet för forskning och utvärdering kring arbetsmarknadspolitik och arbetsmarknadspolitiska åtgärder, Institutet för arbetsmarknads- och utbildningspolitisk utvärdering (IFAU). 



\section{Styrinstrument}

I alla länder används olika styrinstrument såsom lagstiftning, ekonomiska incitament, olika typer av uppföljning och återrapportering (ibland via datoriserade system), informell styrning och dialog. Mixen i denna blandning skiljer sig mellan de olika länderna, och det är intressant att se hur det påverkar arbetsmarknadspolitiken. Nedan redogörs för hur de olika styrinstrumenten används i de fem nordiska länderna. De autonoma regionerna följer sedan i kapitel fem.

\subsection{Styrning via lagstiftning}

Lagstiftningen har en viktig roll i styrningen av arbetsmarknadspolitiken, den definierar roller och fördelar skyldigheter och rättigheter mellan de olika parter som ingår i arbetsmarknadspolitiken. Lagstiftningen i Finland, Island, Norge och Sverige går relativ långt vad gäller styrning av arbetsmarknaden. I Finland kompletteras lagstiftningen med administrativa instruktioner/anvisningar om dess praktiska implementering. ${ }^{21}$ Anvisningarna produceras av Arbets- och Näringsministeriet i syfte att implementeringen av lagarna ska vara enhetlig och likvärdig. Tillsammans med anvisningarna ingår lagstiftningen som en del av ministeriets informationsstyrning av AN-byråerna, som ansvarar för implementeringen av arbetskraftspolitiken. Anvisningarna har en viktig roll och därför händer det också att de följs upp.

Välfärdsministeriet på Island stiftar lagar om all arbetsmarknadspolitik och dessa lagar är strikt styrande för alla parter på arbetsmarknaden. Även om samarbeten mellan parterna är mer horisontellt än vertikalt, det vill säga att till exempel företag kan initiera samarbeten med den statliga Arbetsförmedlingen, har alla parter lagstiftning-

\footnotetext{
${ }^{21}$ All instructions are availabe at: http://www.finlex.fi/fi/viranomaiset/normi/540001/. The most important e.g. Arbets- och näringsministeriet: Arbets- och näringsministeriets anvisning om tillämpningen av lagen och förordningen om offentlig arbetskrafts- och företagsservice TEM/871/00.03.05.02/2015. Anvisning 28.5.2015 https://www.finlex.fi/sv/viranomaiset/normi/540001/42135

Arbets- och näringsministeriets anvisning om arbets- och näringsbyråns uppgifter i genomförandet av systemet med utkomstskydd för arbetslösa TEM/2192/03.01.04/2014. Anvisning 30.12.2014 http://www.finlex.fi/data/normit/41984TEM2192Arbets_och_n_ringsministeriet458129003.pdf
} 
en att förhålla sig till. Samarbeten av både formell och informell karaktär styrs på så sätt av Välfärdsministeriet.

Arbetsmarknadspolitiken i Sverige har länge präglats av regelstyrning och de insatser och verktyg som kan användas styrs relativt hårt av lagstiftningen till exempel vad gäller vem som har rätt till insatser och hur de ska utformas. I de så kallade instruktionerna i den svenska författningssamlingen definieras de uppdrag, långsiktiga mål och uppgifter myndigheter har att följa, däribland Arbetsförmedlingen. Arbetsförmedlingens uppdrag specificeras inte bara i dess instruktion utan också i ett fyrtiotal andra författningar. ${ }^{22}$

"Det finns ju ändå lagar och förordningar som mejslar ut våra verktyg. Sen kan man ju styra mer eller mindre på hur man ska använda den samlade verktygslådan men den samlade verktygslådan är beskriven i lag och förordningar på mer eller mindre detaljerat sätt." ${ }^{23}$ (Intervju med Sjöberg \& Olsson, Arbetsförmedlingen)

Lagstiftningen i Finland, Island och Sverige har sammanfattningsvis en viktig roll vad gäller styrningen av arbetsmarknaden och implementeringen av arbetsmarknadspolitiken. Detta i jämförelse med Danmark där lagstiftningen inte längre används i lika hög utsträckning utan där styrningen blivit mer komplex över tid:

"Nu er en stigende erkendelse af at lovgivningen godt kan bruges til noget, men ikke til alt.

Der er rigtig mange regler. Man må bruge nogle andre mekanismer også. ${ }^{124}$ (Intervju med

Rasmussen, STAR)

Det huvudsakliga styrinstrumentet i Danmark är styrning via ekonomiska incitament men även denna regleras i lagstiftningen liksom kommunernas genomförande av arbetsmarknadsinsatser. Med införandet av "det enstrenget beskæftigelsesystem" (ungefär det enhetliga sysselsättningssystemet) 2009 drog sig staten tillbaka som ansvarig för hela den aktiva arbetsmarknadspolitiken. Det betydde att staten inte längre kunde styra arbetsmarknadspolitiken. Kommunerna stod nu för genomförandet av hela insatsen, och därför fick ekonomiska incitament och andra styrinstrument en större betydelse.

\footnotetext{
${ }^{22}$ Statskontoret 2016:5 Analys av Arbetsförmedlingens interna styrning och utvecklingsarbete. www.statskontoret.se/publicerat/publikationer/2016/analys-av-arbetsformedlingens-interna-styrning-ochutvecklingsarbete/ s. 21.

${ }^{23}$ Sjöberg, Mikael \& Olsson, Clas; Generaldirektör respektive biträdande generaldirektör, Arbetsförmedlingen, Intervju 2015-12-09.

${ }^{24}$ Rasmussen, Helle; Vice direktör, STAR, intervju 2015-11-05.
} 
I Norge har den statliga delen av NAV traditionellt varit relativt detaljerat styrt. Det sker främst genom tilldelning av resurser och aktivitetsstyrning genom tilldelningsbrev och målkort för rapportering. Lagstiftning spelar därmed en mindre, men viktig, roll. Tanken är dock, enligt den ansvariga ministern, att NAV ska bli mindre regelstyrt:

"Den statlige delen av NAV er ganske toppstyrt, regelstyrt og relativt rigid. Jeg tror de fleste som kjenner NAV nikker gjenkjennende til den beskrivelsen. Handlingsrommet for de statlige ansatte er mer begrenset enn for de kommunalt ansatte i NAV. Ved å gjøre det statlige systemet mindre rigid og regelstyrt, vil NAV-kontorene få økt handlingsrom. Samtidig blir den statlige styringen mer lik den kommunale. Det innebærer at partnerskapet mellom stat og kommune også blir mer likeverdig" (Arbeids- og sosialminsiter Anniken Hauglie til Kommunal Rapport ${ }^{25}$ )

Lagstiftning har med andra ord varit viktig för att säkra förutsägbarhet, likhet och en standardiserad förvaltning.

I Norge är det bland annat styrt av lag att kommunerna ska ha NAV-kontor men inte vilka tjänster som ska finnas i dessa och hur de ska organiseras. Alle kommuner ska ha minimumlösningen för sociala tjänster i NAV, dvs. information, vägledning och rådgivning, inklusive ekonomisk rådgiving. Dessutom ska alla kontor ha ekonomisk stønad (socialhjälp), tillfälligt boende, samt erbjuda kvalificeringsprogrammet, en individuell sysselsättningsplan som innehåller arbetslivsinriktade aktiviteter, arbetsträning och uppföljning. Alla har enligt lag rätt till individuell plan. Det finns ett visst frihetsutrymme på kommunal nivå att utforma NAV-kontoren efter lokala behov. De intervjuer som gjorts med lokala chefer tyder dock på att det lokala handlingsutrymmet i praktiken är begränsat, men att det gradvis blir större (se kapitel sex nedan).

Även om lagstiftningen är ett viktigt styrinstrument som reglerar många delar av arbetsmarknaden och funktionerna på den används lagstiftningen i Finland, Island och Sverige för att styra i större utsträckning än i Danmark och Norge. På Island är lagstiftningen strikt styrande men arbetsmarknaden bygger också på horisontella och ibland informella samarbeten mellan exempelvis Arbetsförmedlingen och företag. Lagstiftningen i Sverige kan gå relativt långt vad gäller detaljer, även om det har blivit mindre vanligt på senare tid. I Danmark har det skett ett skifte mot ett allt mer komplext styrsystem med ett ökat fokus på ekonomisk styrning och styrning som bygger på kunskap, för att skapa incitament för kommunerna. ${ }^{26}$ Detta är en följd av kommunaliseringen av arbetsmarknadspolitiken i Danmark. Till skillnad från de andra länderna i Norden är det i

\footnotetext{
${ }^{25}$ Dagens Perspektiv 2016 http://www.dagensperspektiv.no/2016/anniken-hauglie-som-veiviser

${ }^{26}$ Rasmussen, Helle, STAR, Intervju.
} 
Danmark ekonomiska incitament som har kanske den mest betydande rollen i styrningen av arbetsmarknadspolitiken, vilket närmare beskrivs i nästa avsnitt.

\subsection{Styrning via ekonomiska incitament}

Ekonomiska incitament har den mest framträdande rollen i Danmarks arbetsmarknadspolitik vars refusionssystem (refusionsordning) ${ }^{27}$ är en central del av statens styrning av kommunernas arbetsmarknadsinsatser.

Refusionssystemet innebär att kommunernas utgifter för arbetsmarknadsinsatser delvis ersätts av staten. ${ }^{28}$ Det gäller bland annat utgifter för arbetslöshetsdagpengar, kontanthjälp och förtidspension. Till exempel ersätts kommunerna för sina utbetalningar av arbetslöshetsersättning (dagpenger) för dem som har varit arbetslösa i upp till 18 månader. Kommunerna ersätts också till två tredjedelar för sina kompletterade utbetalningar för flexjobbanställda. År 2015 reformerades refusionssystemet till att andelen av kommunernas utgifter som återbetalas, minskar över tid.

"Det er faktiske pointen i den nye refusionsmodel, at det er sådan set op til kommunerne selv, hvad man vil satse på, det vil sige hvilke ydelsesmodtagere man vil satse på. Fordi det er den gradvise aftrapning af refusion fra staten. ${ }^{129}$ (Intervju med Bredgaard, lektor på statsvetenskapliga institutionen på Aalborg universitet)

Poängen med refusionssystemet är alltså enligt Thomas Bredgaard, Aalborg universitet, att det ska vara upp till kommunerna som arbetsförmedlare att välja vad de vill satsa på och vilka målgrupper de vill satsa på. STAR söker att genom refusionssystemet vägleda kommunerna till de mest verksamma insatserna samt de insatser som går i linje med de politiska intentionerna för arbetsmarknaden. Avtrappningen av återbetalningarna ökar incitamentet att välja de insatser som har störst effekt på att få arbetslösa i arbete. Enligt Bredgaard har ändringar i refusionssystemet bidragit till att påskynda kommunernas fokus på aktiveringen av arbetslösa men att det har olika konsekvenser för olika målgrupper, där de som står närmare arbetsmarknaden är lönsammare att få ut i arbete:

\footnotetext{
${ }^{27}$ Här används det danska ordet refusion, även om det inte är vanligt förekommande på svenska. Återbetalning eller ersättning är vanligare ord på svenska, men refusion används för att inte förvirra.

${ }^{28}$ Med den nye refusionsreform på beskæftigelsesområdet, der trådte i kraft den 4. januar 2016, er refusionssatsen - dvs. kommunernes refusion (tilbagebetaling/medfinansiering) fra staten - ens på tværs af ydelser. Tidligere gjaldt forskellige refusionssatser afhængig af, om udgiften var til fx kontanthjælp, arbejdsløshedsdagpenge eller førtidspension, men i dag gives samme refusionssats på tværs af ydelserne. Derudover nedtrappes satsen over tid fra 80 pct. de første fire uger til 20 pct. efter 52 uger ( 1 år). Kommunerne får dermed et økonomisk incitament til at få borgeren i beskæftigelse hurtigst muligt.

${ }^{29}$ Bredgaard, Thomas, Aalborg universitet, intervju 2015-11-10.
} 
"Det er klart at dem som er længst væk fra arbejdsmarkedet, det er jo ikke dem hvor du hurtigt får et afkast på din investering Så man vil nok tage fat i dem hvor man ved. Der er dem som er tæt på arbejdsmarkedet, som kan og vil selv. De skal måske bare have et kærligt skub bagi, der skal man bare sørge for at folk står til rådighed, så skal de nok klare den selv. Og så dem som er over i den anden ende, der hverken kan eller vil, hvor der skal virkelig en massiv indsats til. Det er der, der er en risiko for at man parkerer den gruppe. Og så tager fat i den der mellemgruppe, som man synes man kan arbejde med. Altså dem som muligvis godt vil arbejde og muligvis godt kan."130 (Intervju med Bredgaard, Aalborg universitet)

Denna oro för de svagare grupperna på arbetsmarknaden finns även på andra håll, bland annat hos STAR:

"Det er vores bekymring at investeringerne i de svage gruppe er for stor risiko for kommunerne og fordi nogle af borgerne ikke kommer videre. [...] Vi er bange for de svageste, at de bare lader dem gå, fordi kommunerne synes det for risikabelt af bruge penge på dem. ${ }^{13^{11}}$ (Intervju med Rasmussen, STAR)

De senaste åren har statens återbetalningar varit baserade på vilka insatser kommunerna sätter in men det går mot att återbetalningar ska ske på grundval av de resultat kommunerna uppnår.

I Finland har ekonomiska incitament använts från statligt håll för att öka kommunernas roll på arbetsmarknaden. Från och med 2006 tog kommunerna över hälften av kostnaderna för dem som varit arbetslösa mer än 500 dagar och sedan 2015 ökades det ekonomiska ansvaret till att omfatta hälften av kostnaderna för dem som varit arbetslösa i 300 dagar. Då arbetslöshetstiden uppgår till 1000 dagar ökar kommunens andel till 70 procent. Denna överföring av kostnader från staten till kommunerna har enligt intervjuer dels varit en ren "kostnadsbesparing" för staten, dels syftat till att öka kommunernas intresse för aktivering av arbetslösa.

Gentemot NTM-centralerna får ekonomiska incitament ofta närmast motsatt effekt, som en chef för en NTM-central påpekar:

Jag önskar att det fanns belöningssystem om vi lyckas med något - nu är det så att de regioner som har en svår situation får mer pengar än de andra. Men om du gör ett bra resultat och arbetslösheten minskar och indikatorerna visar grönt på alla nivåer, så kan leda till att du får mindre och mindre pengar. Klart man vill göra sitt bästa, men det finns ingen komponent för att belöna dem som gör bra resultat med någon bonus eller liknande. Hur ministeriet fördelar resurserna har jag egentligen ingen exakt information om, hur de kalkylerar. Men arbetslösheten påverkar osv. Desto värre situation, desto mer pengar. Föregående års årsberättelse inverkar såklart.

\footnotetext{
${ }^{30}$ Bredgaard, Thomas, Aalborg universitet, intervju 2012-11-10.

${ }^{31}$ Rasmussen, Helle, STAR, intervju 2015-11-05.
} 
Även på Island och i Sverige har kommunernas utgifter ökat, dock till följd av ekonomiska incitament riktat mot arbetslösa. År 2015 minskade Välfärdsministeriet på Island antalet månader en individ kan få arbetslöshetsförsäkring från 36 till 30 månader. Efter 30 månader är dessa individers försörjning kommunernas ansvar. Detta har ökat kommunernas kostnader på kort sikt vilket ökat antal aktiviteter som de driver på eget initiativ för att få ut folk i arbete. Totalt sett på Island ser dock reformen ut att betyda minskade kostnader för arbetslöshetsförsäkringen. Även i Sverige har kommunernas utgifter ökat till följd av striktare krav för arbetslöshetsförsäkringen. De som inte är berättigade arbetslöshetsersättning söker försörjningsstöd vilka utbetalas av kommunerna. Många kommuner i Sverige driver liksom kommunerna på Island och Finland egna initiativ för att få ut folk i arbete och på så sätt minska utbetalningarna av försörjningsstöd. Det finns en risk med att kommunerna huvudsakligen drivs av att minska utgifterna snarare än att minska arbetslösheten.

"En del av de arbetslösa som har som huvudsakligt problem att de saknar arbete hamnar hos Arbetsförmedlingen och är försäkrade inom ramen för den statliga arbetslöshetsförsäkringen. Många hamnar i ekonomiskt bistånd hos kommunen istället. ${ }^{132}$ (Intervju med Forslund, IFAU)

Förändringarna i arbetslöshetsersättningen har i Sverige lett till att även mottagare av försörjningsstöd från kommunerna i stor utsträckning har arbetslöshet som sitt huvudsakliga försörjningshinder. Det finns enligt Anders Forslund, professor i nationalekonomi vid Uppsala universitet och anställd på utvärderingsmyndigheten IFAU i Sverige, indikatorer som pekar mot att "kommunen ordnar insatser där huvudsyftet är att slippa betala försörjningen för dem så småningom" till exempel genom att själva anställa mottagare av försörjningsstöd tillräckligt länge för att de ska uppfylla arbetsvillkoren för arbetslöshetsförsäkringen:

"Då kan man misstänka att insatserna inte drivs av att personerna ska komma ut på arbetsmarknaden på ett bra sätt, utan snarare motiveras av att man vill bli av med att betala försörjningsstöd. ${ }^{133}$ (Intervju med Forslund, IFAU)

I Finland där kommunernas ekonomiska ansvar ökat specifikt för de långtidsarbetslösa upplevs det på vissa håll att de grupper kommunen är ekonomiskt ansvariga för i större utsträckning får ta del av den s.k. sektorsövergripande samservice som främjar sysselsättningen samtidigt som andra målgrupper med behov av denna typ av service riskerar att åsidosättas.

\footnotetext{
${ }^{32}$ Forslund, Anders IFAU, intervju 2015-11-25.

${ }^{33}$ Forslund, Anders IFAU, intervju 2015-11-25.
} 
I Danmark används ekonomiska incitament för att styra arbetsmarknadsinsatser medan det i Finland används för att kommunerna ska ta ett större ansvar. Ekonomiska incitament riktade mot arbetslösa har på Island och i Sverige fått effekten att många kommuner utvecklat egna arbetsförmedlande verksamheter för att minska sina ökade utgifter av försörjningsstöd till följd av ändrade krav inom arbetslöshetsförsäkringen. I de övriga länderna finns inslag av antingen indirekta eller direkta ekonomiska incitament som styrmedel gentemot kommunerna. I Danmark är detta för att kommunerna ansvarar för implementeringen av den aktiva arbetsmarknadspolitiken medan det $\mathrm{i}$ Finland, Island, Norge och Sverige är en följd av styrningen av den passiva arbetsmarknadspolitiken, där kostnad överförs från staten till kommunerna. I Danmark har de ekonomiska incitamenten formen av återbetalningar för kommunernas utgifter medan det i Finland, Island, Norge och Sverige hör ihop med kommunernas ansvar över ekonomiska ersättningar till arbetslösa.

I Norge används ekonomiska incitament (i likhet med övriga länder) för att individer ska stå till arbetsmarknadens förfogande, men i Norge används ekonomiska incitament mellan aktörer i mindre utsträckning än i övriga länder, även om det förekommer både mot NAV-kontoren och mellan statliga och kommunala delen av NAV. I Norge har man medvetet (enligt kunskapsdirektör på NAV, Yngvar Åsholt) varit försiktig med att använda ekonomiska incitament som styrmedel mot privata aktörer som är involverade i arbetsmarknadspolitiken, eftersom detta kan leda till en "creaming"-effekt, där de privata aktörerna lägger mer resurser på de som redan står nära arbetsmarknaden. ${ }^{34}$ Dock har samarbetet med kommunerna har resulterat i kostnadsövervältring från kommunerna till staten (från socialbidrag till det nationella försäkringssystemet). Detta är en följd av att de kommunala stödsystemen saknar tillräckliga incitament att följa upp mottagarna av stöd så länge de inte bär det ekonomiska ansvaret för deras försörjning. Systemet som det är konfigurerat leder till att många av de unga får stöd (AAP och därmed sjukförklaras) utan att egentligen ha en allvarlig sjukdom. De har ofta en diffus eller komplicerad problematik som gör det svårt att diagnostisera. I många fall får de en psykiatrisk diagnos som ångest eller depression. Men det är ofta psykiska symptom, klara problem, sociala problem och dålig självkänsla. Genom att ge dem stöd är de sjukförklarade och det bekräftas för dem att de har ett hälsoproblem och få en hälsokarriär snarare än krav på att bli en del av arbetsmarknaden. ${ }^{35}$ Detta resonemang får stöd av Simen Markussen, seniorforskare vid Frischcentret:

\footnotetext{
${ }^{34}$ Intervju med Yngvar Åsholt, kunskapsdirektör, NAV.

${ }^{35}$ Mandal et al., SINTEF (2015) Hvordan fungerer arbeidsavklaringspenger (AAP) som ytelse og ordning? http://www.sintef.no/globalassets/sintef-teknologi-og-samfunn/rapporter-sintef-ts/aap_rapport_sintef.pdf
} 
[I] utviklingen av ytelsesbruk i NAV-systemet [...] ser vi en klar dreining av sykepenger, dagpenger, sosialhjelp over til AAP. Det er en stor ytelse. Den dreiningen kan bare delvis forklares med endring blant brukerne og konjunktur. Brukerne som før hadde fått dagpenger, sosialhjelp, osv. nå oftere får AAP. En stipendiat hos oss har sett på effekter av det, betydningen for unge (18-30 år) på AAP. Ser at helse er blitt prioritert opp på kontorene. Dette har en ganske negativ effekt for ungdommene. Ser man på ordningene, er de innrettet slik at det lønner seg å være syk. Du får mer penger hvis du er syk. Du får mer hjelp, mer verdighet. Og så tjener kommunen på det. Det ligger noe i systemet som presser eller lokker folk inn i helsefellen. Da er det vanskeligere å komme inn i arbeidslivet igjen etterpå. (Simen Markussen, Frischcentret).

Det finns således en risk med ekonomiska incitament och det är att fokus kan hamna på att få så mycket pengar tillbaka (som i Danmark) och på att minska utgifterna (som i Finland, Island och Sverige). När fokus ligger på utgifterna finns en risk för att fokus hamnar på dem som står närmare arbetsmarknaden och kortsiktiga lösningar eftersom detta ger större vinst (eller minst förlust).

\subsection{Mål- och resultatstyrning}

Mål- och resultatstyrning är en viktig del av arbetsmarknadspolitiken i Danmark, Finland, Norge och Sverige där prestationsmål och rapporteringskrav används för att styra riktningen av arbetsmarknaden och insatserna på den.

De lokala jobbcentren i Danmark har det operationella och ekonomiska ansvaret för arbetsmarknadsinsatser samtidigt som de till stor del styrs centralt. En del av denna kontroll av de kommunala jobbcentren sker via mål- och resultatstyrning. Beskæftigelsesministeriet sätter årligen anställningsmål som formuleras tillsammans med STAR. Enligt lagen om organisation och stöd, etc. (LOB) $\ 19$, ska arbetsmarknadsministern varje år tillkännage ett antal vägledande mål för arbetsmarknadspolitiken under det kommande året. Tillkännagivandet av sysselsättningsmål är avsedda att fokusera på de områden där det finns ett behov av ökade insatser i kommunerna. De nationella målen är få men breda och fokuserade för att de kommunala jobbcentren ska kunna utforma egna relevanta och specifika mål inom detta nationella ramverk. Det är kommunernas ansvar att anpassa och kvantifiera målen lokalt. Kommunerna har också möjlighet att lägga till mål beroende på vilka behov som finns på den lokala arbetsmarknaden. Den nationella målstyrningen är till för att anpassas lokalt och utgör en möjlighet för benchmarking mellan kommunerna, vilket det i Dan- 
mark finns ett utarbetat system för. ${ }^{36}$ Hjemmesiden "jobindsats.dk" samler data om kommunernes beskæftigelsesindsats og giver både kommuner og STAR mulighed for at sammenligne den kommunale indsats med andre kommuner.

I Finland sätter Arbets- och näringsministeriet årligen de nationella strategiska målen till vilka NTM-centralerna i nära samarbete med AN-byråerna svarar på genom att definiera prestationsmål. Prestationsmålen distribueras formellt via NTM-centralen, men är i praktiken direkt ställda till AN-byrån. Systemet inkluderar tiotals resultat-, effekt-, process- och kvalitetsmål. ${ }^{37}$ Indikatorerna är de samma i samtliga regioner, men nivån på själva målsättningarna varierar enligt regionens förutsättningar. Måluppfyllelsen är dock inte kopplad till några incitament för de enskilda AN-byråerna, och bortsett från NTM-centralernas årsredovisning sker ingen direkt återrapportering. Utvecklingen hos varje AN-byrå följs dock upp genom automatiska datasystem, där AN-byrån, NTMcentralen och ministeriet har tillgång till samma information. Mer informell dialog kring resultatuppfyllelse kan dock förekomma på de regelbundna möten som sker dels på regional nivå mellan AN-byrån och NTM-centralen, dels på central nivå där direktörerna AN-byråerna och NTM-centralen och ministeriet träffas för att utbyta information om bland annat utvecklingen på arbetsmarknaden. Traditionellt sett har det varit mycket fokus på att varje aktivitet fungerar för sig och inte en analys av vilka effekter de får för hela systemet.

I Norge är mål- och resultatstyrning den grundläggande principen för styrningen där Arbets- och socialdepartementet (ASD) ansvarar för den övergripande styrningen via överordnade mål för arbetsmarknadspolitiken, men även detaljstyrning sker i vissa fall $i$ samband med vilka projekt och satsningar som ska prioriteras. Departementet styr Arbeids- og velferdsdirektoratet (NAV) via tilldelningsbrev som definierar de ekonomiska ramarna, prioriteringarna, resultatmålen och rapporteringskraven som gäller. Departementets prioriteringar vidareförmedlas från Arbets- och välfärdsdirektoratet (NAV) till de 19 enheterna inom NAV-Fylke via mål- och disponeringsbrev som innehåller de gällande prioriteringarna, målen och strategierna för perioden samt indikatorer för aktiviteter, kvalitet och resultat/effekt. NAV-Fylke skickar sedan ut egna mål- och tilldelningsbrev till NAV-kontoren där budgetramarna och prioriteringarna för året tydliggörs. NAV-kontorens återrapportering baseras på så kallade målkort som fungerar som mätnings- och övervakningsinstrument. NAV-kontoren rapporterar månadsvis till NAV om målkortens indikatorer, mellan 20 och 30 indikatorer uppdelade i brukare, medarbetare,

\footnotetext{
${ }^{36}$ European Commission, 2013, Employment, Social Affairs \& Inclusion, Peer Review "Peer Review on Performance Management in Public Employment Services (PES)" Peer PES Paper, Denmark.

${ }^{37}$ Exempel på indikatorer är andelen positiva serviceerfarenheter bland arbetsgivarkunder/arbetssökande kunder, inflöde till arbetslöshet i över tre månader, antalet svårsysselsatta, med mera.
} 
produktion och ekonomi. Exempel på indikatorer som finns med på målkorten är andel kontakt med användare inom 48 timmar efter förfrågan, andel arbetssökande som registrerar sig själva på NAV:s hemsida och antal mottagare av ekonomisk socialhjälp som är under 25 år. Denna rapportering kan sedan få ekonomiska konsekvenser eftersom NAV baserat på dessa gör en värdering om det finns ett behov av resursomfördelningen mellan länens arbetsmarknadsutbildningar (tiltaksplasser). Detta innebär dock inget nollsummespel mellan länen baserat på deras resultat. När resurserna omfördelas görs det i dialog med länen och extrafinansiering kan komma från en buffertpott. NAVkontoren rapporterar även till kommunerna värden på minst fem specifika indikatorer, däribland andel mottagare av socialförsäkring och andel verksamheter som fått arbetsmarknadsbistånd från NAV. NAV-kontoren skickar även tertialrapporter där de rapporterar både kvantitativt och kvalitativt samt redovisar bedömningar av resultaten och ger en beskrivning av arbetsmetoderna. NAV för också löpande uppföljningar av NAVkontoren dock mer inriktat på vilka aktiviteter som stödjer måluppfyllelsen, i form av antal platser och antal medel. ${ }^{38}$ Överordnade mål sipprar på detta sätt ner genom nivåerna. De mycket detaljerade återrapporteringskraven har enligt kunskapsdirektören på NAV fått stora konsekvenser:

"NAV har hatt styringsmessige utfordringer når det gjelder styringen av arbeidsmarkedspolitikken. Ved innføringen av flere resultatmål, har styringen blitt nesten parodisk.

Det har vært sterk grad av toppstyring gjennom pålegg og resultatmål fra departementet, gjennom mål og disponeringsbrev. [...]Arbeidsmarkedspolitikken har vært veldig aktivtetsstyrt, og i mindre grad resultatstyrt. Det har vært fokus på aktiviteter og omfang, men enn resultater og om det faktisk virker. [...]Det har vært en uheldig styring.. Får en viss sum og det medfører at det velges billige plasser og tiltak. Det kan være at du da velger billige plasser som du vet at ikke er hensiktsmessig og vet at neppe vil føre til måloppnåelse med at flere kommer opp i arbeid. Men sånn blir det når en har blitt målt på aktiviteter og volum (antall plasser og tiltak) og ikke om det virker." (Yngvar Åsholt, Kunskapsdirektör NAV).

I Sverige styr Arbetsmarknadsdepartementet bland annat Arbetsförmedlingen via årliga regleringsbrev. Dessa innehåller regeringens mål- och resultatkrav på myndigheten, de övergripande reglerna och riktlinjerna för arbetet och refererar till lagstiftningen där respektive myndighets uppdrag finns. Under 2012-2014 hade Arbetsförmedlingen ungefär ett trettiotal uppdrag i regleringsbrevet med krav på återrapportering ibland så ofta som varje månad. Regleringsbrevet för 2016 innehåller till följd av minskad detaljstyrning totalt endast ett tiotal uppdrag och återrapporteringskraven är

\footnotetext{
${ }^{38}$ Ekspertgruppen (Vågeng-utvalget), Et NAV med muligheter - Bedre brukermøter, større handlingsrom og tettere på arbeidsmarkedet, 2015 .
} 
också färre och mindre detaljerade. ${ }^{39}$ Utvecklingen mot mindre detaljstyrning från regeringens håll är något Statskontoret i sin analys av Arbetsförmedlingens interna styrning och utvecklingsarbete bedömer som fortsatt viktigt. ${ }^{40}$ Styrningen har blivit mer inriktad på resultat och större frihet vad gäller insatser, för att ge den enskilda förmedlaren större utrymme att utifrån sin professionella kompetens anpassa insatserna bättre för den enskilda sökande och den lokala arbetsmarknaden. Utifrån målen i regleringsbrevet formulerar Arbetsförmedlingens ledning övergripande, realistiska och nedbrytbara verksamhetsmål som finns i den årliga verksamhetsplanen vilken är en utgångspunkt för generaldirektörens uppföljning av verksamheten.

\footnotetext{
"Vi har ju en traditionell verksamhetplaneringsprocess där man skriver vad man vill åstadkomma och vad man behöver för resurser. Processen börjar med att generaldirektören sätter ihop ett inriktningsdokument som ska ange vilka frågor som är prioriterade på övergripande nivå, det kommer från regleringsbrevet. Sen får ju varje enhet göra sin verksamhetsplanering, som vi sedan följer kvartalsvis på ledningsnivå." (Clas Olsson, i intervju med Mikael Sjöberg, generaldirektör \& Clas Olsson, biträdande generaldirektör Arbetsförmedlingen)
}

Baserat på regleringsbrevet och dess mål- och resultatkrav på myndigheten samt hur stora anslag Arbetsförmedlingen får, gör de återrapporteringar genom vilka regeringen kontrollerar att intentionerna för arbetsmarknadspolitiken uppfylls. Det ekonomiska utfallet rapporteras månadsvis där det bland annat redovisas utbetalda belopp per anslag, anslagsposter och insatser under de anslag som disponeras av Arbetsförmedlingen. Arbetsförmedlingen producerar också årliga arbetsmarknadsrapporter vars avsikt är att presentera en kvalificerad analys av hur arbetsmarknaden fungerar och av Arbetsförmedlingens roll $\mathrm{i}$ att förbättra arbetsmarknadens funktionssätt. Från och med år 2015 görs de årliga arbetsmarknadsrapporterna på myndighetens eget initiativ istället för på uppdrag av regeringen men rapporten tar sin utgångspunkt i regeringens mål för den arbetsmarknadspolitiska verksamheten. Som en del av uppdraget att analysera utvärderar Arbetsförmedlingen hur verksamheten och de arbetsmarknadspolitiska insatserna påverkar arbetsmarknadens funktionssätt. Arbetsmarknadsdepartementet och Arbetsförmedlingen har även löpande kontakter såväl på ledningsnivå som på tjänstemannanivå. I och med att Arbetsmarknadsdepartementet har släppt på detaljstyrningen har dialogen med Arbetsförmedlingen om uppdraget och resultatutvecklingen ökat. Informationsutbytet går åt båda hållen där Arbetsförmedlingen nu i större utsträckning

\footnotetext{
${ }^{39}$ Statskontoret, 2016, s. 21

${ }^{40}$ Statskontoret, 2016.
} 
bidrar till att ta fram underlag till politikutvecklingen som sker vid departementet samtidigt som de också fått mer karaktär av expertmyndighet. ${ }^{41}$

"Den informella styrningen är ganska omfattande. Vi har löpande kontakt med departementet där man diskuterar olika frågor, alltifrån att generaldirektören träffar ministern till att tjänstemän träffar tjänstemän. Det har blivit lite mer omfattande med den ökade friheten, departementet undrar hur det går och vill ha mer hjälp av oss i utformningen av politiken. ${ }^{142}$ (Intervju med Wadman, Analyschef Arbetsförmedlingen)

En del av mål- och resultatstyrningen sker via budgeten. I Finland består ANbyråernas budgetar av två delar, en operationell del som går direkt från ministeriet till AN-byråerna och en del för den aktiva arbetskraftspolitiken som når AN-byråerna via NTM-centralerna. Den första delen av budgeten ska exempelvis täcka AN-byråernas personalkostnader och är relativt stabil över tid. Den del AN-byråerna får återspeglar hur stort kontoret är vad gäller antal anställda samt de produktivitetsmål som är kopplade till kontoret. ${ }^{43}$ Den andra delen av budgeten bestäms av ministeriet efter att ha konsulterat NTM-centralerna som styr och övervakar AN-byråerna. NTMcentralerna förbereder sedan tillsammans med AN-byråerna årligen en strategiplan med prestationsmål och tillhörande budgetbehov. ${ }^{44}$ Vissa delar av budgeten har varit politiskt öronmärkta, till exempel för långtidsarbetslösa.

I Norge preciseras budgetramarna i olika led tillsammans med tillhörande prioriteringar och mål. Även i Sverige har budgetpropositionen en viktig roll i styrningen av Arbetsförmedlingen. I den avsätts mängden medel för olika insatser och till viss del preciseras också antal platser kopplade till utbildnings- och arbetsmarknadsinsatser. ${ }^{45}$

"Även hur man fördelar pengarna genom att låsa in dem i olika insatser var en del av denna detaljstyrning. Det låser möjligheten att använda pengarna på bästa möjliga sätt. Detaljstyrningen slår också på operativ nivå ända ner till de enskilda förmedlarna, eftersom förmedlarna vet att de ska redovisa hur många de har i en insats och bedömas efter det. Då ser man till att de finns där - en självbevarelsedrift. ${ }^{\prime 4^{6}}$ (Intervju med Wadman, Analyschef Arbetsförmedlingen)

\footnotetext{
${ }^{41}$ Sjöberg \& Olsson, Arbetsförmedlingen, intervju 2015-12-09; Wadman, Mats, analyschef Arbetsförmedlinge, intervju 2015-11-20; Löw och Jarefors, Arbetsmarknadsdepartementet, Intervju 2016-01-28.

${ }^{42}$ Wadman, Mats, Arbetsförmedlingen, intervju 2015-11-20.

${ }^{43}$ Weishaupt, 2014.

${ }^{44}$ Weishaupt, 2014.

${ }^{45}$ Regeringens proposition 2015/16:1.

${ }^{46}$ Wadman, Mats; Analyschef Arbetsförmedlingen, Intervju 2015-11-20.
} 
Denna detaljstyrning där budgeten låses in i olika insatser har i Sverige minskat över tid. ${ }^{47}$

Till skillnad från Danmark, Finland, Norge och Sverige finns det ingen effektiv mål- och resultatstyrning på Island och de arbetsförmedlande verksamheterna har inga rapporteringskrav knutna till sig. Styrningen av arbetsmarknaden på Island sker i huvudsak via lagstiftning och kontraktsskrivning vid samarbeten. Arbetsförmedlingen på Island skriver rapporter om arbetsmarknadsinsatser månadsvis och årligen samt rapporter om arbetsmarknadssituationen men det finns inget system för återrapportering. Arbejdsdirektoratetet godkänner årligen myndighedens verksamhetsplan. Ministeriet har tillgång till planen och kan kommentera på den om nödvändigt. Återrapportering till Välfärdsministeriet sker i övrigt primärt vid behov.

Figur 18: Återrapportering

Danmark

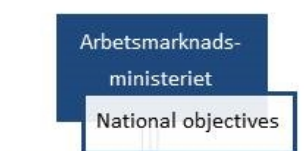

STAR

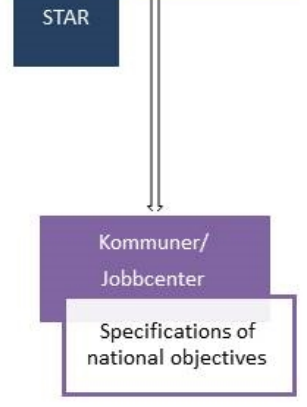

Finland

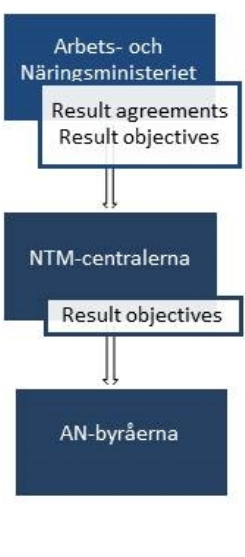

Norge

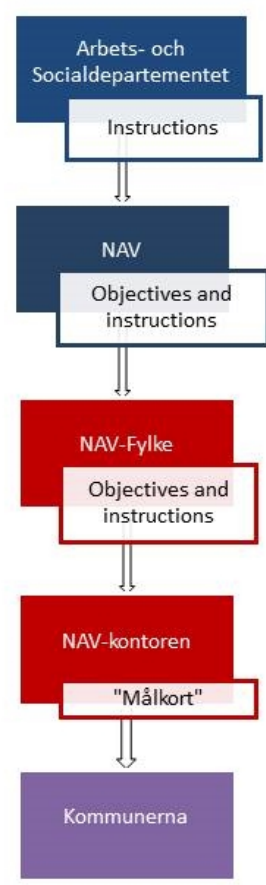

Sverige

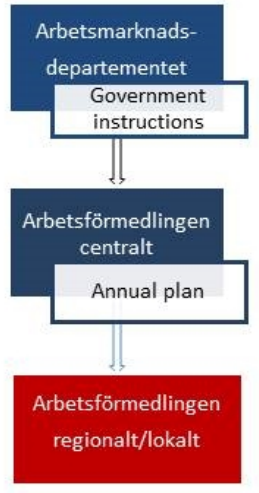

${ }^{47}$ Intervjuer med Mats Wadman, Mia Löw och Jonas Jarefors. 


\subsection{Uppföljning och utvärdering}

Ansvaret för att systematiskt samla in, utveckla och förmedla kunskap och data på arbetsmarknadsområdet ligger i Danmark hos STAR. STAR har till uppgift att övervaka utvecklingen på arbetsmarknaden både nationellt, regionalt och kommunalt. I april 2016 lanserades ett nytt nyckeltalkoncept som ska göra det enklare för kommuner att följa, bevaka och jämföra utvecklingen på arbetsmarknaden med andra kommuner. STAR ansvarar för tillsynen av A-kassan samt tillsynen av kvaliteten på kommunernas arbete, att de följer lagar och regler, samt att medborgarna får arbetsmarknadstjänster. STAR rådgör med Tilsynsrådet angående dessa frågor. Statistiska analyser och utvärderingar om vilka aktiva arbetsmarknadsinsatser som fungerar görs i hög grad av externa analysverksamheter och universitet i samarbete med STAR. ${ }^{48}$ STAR genomför också studier inom det arbetsmarknadspolitiska området med målet att mäta effekterna av arbetsmarknadsinsatser. Tilsynsrådet har tre uppgifter: att ge råd till beskæftigelsesministeren och STAR, att behandla STAR:S lägesrapporter var sjätte månad, samt att övergripande bevaka tillsyn inom arbetsmarknadspolitiken.

Rigsrevisionen och Det Økonomiske Råd kan också välja att göra utredningar på området. $^{49}$

Eftersom den aktiva och passiva arbetskraftspolitiken är tudelad redan på toppnivå i Finland har Arbets- och näringsministeriet ansvaret att följa upp den aktiva arbetskraftspolitiken medan Social- och hälsovårdsministeriet har ansvaret att följa upp den passiva arbetskraftspolitiken. Som en del av mål- och resultatstyrningen följs ANbyråernas resultatmål upp genom automatiserade system, men Arbets- och näringsministeriet tillhandahåller också utvärderingar av hur väl de arbetsförmedlande insatserna fungerar. Sådana studier görs dels internt, dels genom upphandling av olika aktörer som konsultföretag, forskningsinstitut och akademin. I Finland finns också Statens ekonomiska forskningscentral som inom sitt uppdrag att producera kunskap om den offentliga ekonomin till viss grad utvärderar effekterna av både den passiva och aktiva arbetskraftspolitiken. Även Statens revisionsverk utför effektivitetsrevisioner av arbetskraftspolitiken.

Island skiljer sig från de andra länderna i Norden då det inte har ett system för rapportering, uppföljning och bevakning mellan nivåerna. Eftersom det är en prioritet för Arbetsdirektoratet att investera i de mest effektiva resurserna bevakas och utvärderar de själva de flesta arbetsmarknadsinsatserna för att se vilka insatser som är mest effek-

\footnotetext{
${ }^{48}$ http://star.dk/upload/STAR/Files/Servicemenu/STAR-strategi-2015.pdf

${ }^{49}$ Till exempel en utredning om effekten av aktivering av icke arbetsföra kontanthjälpsmottagare 2010, där statsrevisorn kritiserade ministern och ministeriet för att inte kunna dokumentera att aktivering fungerar så som det var tänkt.
} 
tiva och vilka effekter som följer av dem. Arbetsförmedlingen kontrollerar och mäter resultaten för sina egna program efter sina egna metoder och beslutar baserat på detta om de ska fortsätta med insatser eller inte. De producerar månatliga och årliga rapporter som tillgängliggörs via hemsidan. Rapporteringar mellan nivåerna och i relation till andra aktörer görs på ett informellt sätt. Eftersom det finns ett gott samarbete mellan institutioner som Arbetsförmedlingen och Välfärdsministeriet ges information på begäran. Kopplat till arbetsförmedlingskontoren utvärderar marknadsråden (bestående av arbetsmarknadens parter) vilka arbetsmarknadsinsatser eller resurser som passar regionen bäst och rapporterar detta till Arbetsförmedlingen. Islands Riksrevisions roll rör snarare statens finanser än implementeringen av arbetsmarknadspolitiken.

Utöver NAV-kontorens tertial- och månadsrapporter i Norge gör även Arbets- och socialdepartementet (ASD) uppföljningar av NAV via kontaktmöten, ledningsmöten och internmöten vid särskilda problem. Motsvarande rutiner gäller också inom myndigheten på olika nivåer, mellan fylken och centralt och mellan fylken och lokalt.

Riksrevisionen som ligger under parlamentet har i sin tur ansvaret för att granska ASD med underliggande verksamheter. Utvärderingar har även gjorts av Statistiska centralbyrån, samhällsvetenskapliga institutioner och kommersiella aktörer. Den aktör som mest regelbundet gör analyser och utvärderingar av den norska arbetsmarknadspolitiken är dock NAV själv. NAV gör dels egna analyser och utvärderingar, dels finansierar NAV andra aktörer som gör den typen av rapporter. Kunskapsproduktionen är stor. De analyser som görs av NAV själv publiceras antingen i tidskriften Arbeid og velferd eller i en särskild rapportserie. De rapporter som NAV finansierar görs vanligen av forskare på universiteten, och NAV har ett etablerat samarbete med flera högskolor och universitet. Frisch-centret, som är ett fristående forskningscenter grundat av Oslo universitet är ett exempel på ett organ som gör många studier och evalueringar inom arbetsmarknadspolitiken. Simen Markussen, seniorforskare på Frischcentret anser dock att man generellt sett vet väldigt lite om effekter inom arbetsmarknadspolitiken. ${ }^{50}$

I Sverige rapporterar Arbetsförmedlingen om förhållanden på arbetsmarknaden men under Arbetsmarknadsdepartementet finns även Inspektion för arbetslöshetsförsäkringen (IAF) som har ansvar för att bland annat utöva tillsyn över bland annat arbetslöshetsförsäkringen samt Arbetsförmedlingens uppdrag. Under Arbetsmarknadsdepartementet ligger även Institutet för arbetsmarknads- och utbildningspolitisk utvärdering (IFAU), som har ett uppdrag att undersöka effekter av arbetsmarknadsoch utbildningspolitik, arbetsmarknadens funktionssätt och arbetsmarknadseffekter av socialförsäkringen. Att ha en egen myndighet för forskning och uppföljning av ar-

\footnotetext{
${ }^{50}$ Intervju med Simen Markussen. Frischcentret. September 2016.
} 
betsmarknadspolitiken är något som är unikt för Sverige. Riksrevisionen granskar alla myndigheter inom arbetsmarknadspolitiken och genomför granskningar av enskilda insatser och reformer inom såväl passiv som aktiv arbetsmarknadspolitik. Statskontoret gör på uppdrag av regeringen utredningar och utvärderingar inom alla sektorer och rapporterna används för effektivisering och omprövning av statlig verksamhet.

Intressant att notera är hur länderna arbetar med metodutveckling, lärande och experiment inom arbetsmarknadspolitiken. I Finland är det till exempel vanligt att från ministeriets sida testa en ny reform eller ny åtgärd först på en avgränsad region, för att på så sätt se hur det fungerar och sedan skala upp åtgärden om det visar sig fungera bra. I Norge utför NAV "forsøk", det vill säga experiment, där man testar nya metoder under kontrollerade former, till exempel Supported Employment. Dessa forsøk påminner om de metodutvecklingsprojekt som finansieras av Europeiska Socialfonden (ESF) i Danmark, Finland och Sverige.

De största skillnaderna mellan de nordiska länderna vad gäller uppföljning och utvärdering av arbetsmarknadspolitiken är att det i Island inte finns något system för rapportering, uppföljning och utvärdering mellan samhällsnivåerna och att det i Sverige finns en egen myndighet för arbetsmarknadspolitisk utvärdering. I Danmark, Finland, Norge och Sverige är annars mål- och resultatstyrningen en del av utvärderingen av arbetsmarknadspolitiken.

\subsubsection{Utvärdering av arbetsmarknadspolitiken (vem gör vad på vems initiativ)}

\section{Danmark}

STAR

- Samlar in, utvecklar och förmedlar kunskap och data om arbetsmarknadsområdet.

- Övervakar utvecklingen på arbetsmarknaden, nationellt, regionalt och kommunalt.

- Ansvarar för tillsyn av A-kassan.

- Ansvarar för tillsyn av kvaliteten på kommunernas arbete, att de följer lagar och regler.

- Ser till att medborgarna får arbetsmarknadstjänster.

Rigsrevisionen

- Riksrevisionen reviderar på uppdrag av Folketinget den aktive arbetsmarknadspolitiken.

- Levererar rapporter om Beskæftigelsesministeriets implementering av reformer och om effekten av de kommunala sysselsättningsinitiativen. 
Finland

Arbets- och Näringsministeriet

- Följer upp den aktiva arbetskraftspolitiken.

- Tillhandahåller interna och externa utvärderingar av hur väl de arbetsförmedlande insatserna fungerar.

AN-byråerna

- Automatisk återrapportering av utfallet på resultatmålen.

Social- och hälsovårdsministeriet

- Följer upp den passiva arbetskraftspolitiken.

Statens ekonomiska forskningscentral

- Producerar kunskap om den offentliga ekonomin.

- Utvärderar effekterna av både den passiva och aktiva arbetskraftspolitiken.

Statens revisionsverk

- Genomför effektivitetsgranskningar av sysselsättnings- och arbetsmarknadspolitiken.

\section{Island}

Arbetsförmedlingen

- Bevakar och utvärderar egna insatser efter egna metoder.

- Producerar månads- och årsrapporter.

- Skriver årliga arbetsmarknadsrapporter.

Arbetskontorens marknadsråd (bestående av arbetsmarknadens parter)

- Utvärderar vilka arbetsmarknadsinsatser eller resurser som passar regionen bäst och rapporterar detta till Arbetsförmedlingen.

Riksrevisionen

- Hanterar statens finanser snarare än implementeringen av arbetsmarknadspolitiken.

*Island har inget formellt system för rapportering, uppföljning och bevakning mellan nivåerna. 


\section{Norge}

Arbets- och Socialdepartementet (ASD)

- Uppföljningar av NAV via möten och baserat på NAVs tertialrapporter erhålla externa utredningar/rapporter.

- $\quad$ Arbets- och välfärdsdirektoratet.

- Tillhandahålla interna och externa utredningar/utvärderingar hur deras egna insatser fungerar.

NAV-kontoren

- Månadsrapporter till NAV och kommunerna baserat på målkort.

\section{Riksrevisionen}

- Granskar ASD och NAV. Insatserna och om de ligger i linje med politiska prioriteringar granskas genom förvaltningsrevisionen som granskar både NAV och andra myndigheter.

*Utvärderingar har även gjorts av Statistisk sentralbyrå, samhällsvetenskapliga institutioner och kommersiella aktörer.

\section{Sverige}

Arbetsförmedlingen

- Återrapporterar till Arbetsmarknadsdepartementet baserat på mål- och resultatkraven i regleringsbreven.

- Skriver årliga arbetsmarknadsrapporter.

Inspektionen för arbetslöshetsförsäkringen, IAF

- Utövar tillsyn över arbetslöshetsförsäkringen, arbetslöshetskassorna och Arbetsförmedlingens handläggning av ärenden som rör arbetslöshetsförsäkringen.

- Följer utvecklingen på arbetslöshetsförsäkringens område och tar de initiativ till åtgärder som uppföljningen ger anledning till.

Institutet för arbetsmarknads- och utbildningspolitisk utvärdering

- Undersöker effekter av arbetsmarknads- och utbildningspolitik.

- Undersöker arbetsmarknadens funktionssätt.

- Undersöker arbetsmarknadseffekter av socialförsäkringen.

\section{Riksrevisionen}

- Granskar alla myndigheter.

- Granskar enskilda insatser och reformer inom passiv och aktiv arbetsmarknadspolitik. 
Statskontoret

- Gör på uppdrag av regeringen utredningar och utvärderingar inom alla sektorer.

- Rapporterna används för effektivisering och omprövning av statlig verksamhet.

\subsection{Parternas roll}

Samtliga nordiska länder utgår från en arbetsmarknadsmodell som starkt inkluderar arbetsmarknadens parter. I Danmark, Finland och Sverige är arbetsmarknadens parter involverade i och med att A-kassorna är anknutna till fackföreningarna enligt det s.k. Gent-systemet. På Island behandlas alla arbetsmarknadsrelaterade frågor i trepartskonstellationer i vilka parterna (till exempel fackföreningar, Icelandic Confederation of Labour, Federation of Employers) har en viktig roll. På Island konsulteras parterna alltid av Välfärdsministeriet i arbetsmarknadspolitiska ärenden. Även i Danmark konsulteras parterna (till exempel Hovedorganisation for fagforeninger och Dansk Arbejdsgiverforening) innan Folketinget fattar beslut om lagförslag och ingår i trepartssamarbeten vad gäller regleringar av arbetsmarknadspolitiken. I Danmark, och mer frekvent i Finland, sker trepartsförhandlingar kring reformer mellan regering, fackföreningar och arbetsgivarorganisationer.

I Danmark ingår arbetsmarknadens parter i det nationella Arbetsmarknadsrådet (BER) och spelar via det en roll i utvecklingen och styrningen av arbetsmarknadspolitiken genom att rådgöra med arbetsmarknadsministern i flera arbetsmarknadspolitiska frågor. Detta är en unik konstruktion från ett internationellt perspektiv eftersom parterna på detta sätt får inflytande i själva politiken..$^{51}$ På regional nivå ingår parterna i de åtta Regionala Arbetsmarknadsråden (RAR) som koordinerar arbetsmarknadsinsatser och riktar insatser mot områden med brist på arbetskraft samt områden med hög arbetslöshet. Även på Island och i Finland är arbetsmarknadens parter involverade på regional nivå, via marknadsråd som är knutna till arbetsförmedlingarna i Island respektive rådgivande Delegationer för arbetsmarknad och näringsliv knutna till AN-byråerna i Finland.

Parternas roll i Danmark har i och med reformer förändrats mot att bli mer reaktiv, det vill säga snarare handla om konsultation än tillsyn av arbetsmarknadsinsatser, styrning, och implementering.

\footnotetext{
51 Jørgensen 2006.
} 
"Samtidig med at man har decentraliseret, har man egentlig også centraliseret. Så derfor har vi kaldt det en decentral centralisering. Selvom det lyder lidt modsætningsfyldt. Og det har også betydet at arbejdsmarkedets parter er kørt ud på et sidespor, de sad jo inde i maskinrummet før i arbejdssystemet. Nu er de ligesom sat ude på sidelinjen. Det har været konsekvensen af styringsreformen." (Intervju med Bregaard, forskare vid Aalborg universitet).

I likhet med Bredgaard mening visar flera studier från CARMA (Centre for labour market research, Ålborg Universitet) att arbetsmarknadens parter tidigare haft en mer aktiv roll än idag. ${ }^{52}$ Däremot finns det på senare tid exempel på att arbetsmarknadens parter har bjudits in till trepartssamtal. Under 2016 bjöd regeringen in parterna för diskussion om invandrares väg in på arbetsmarknaden. Liknande trepartsamtal på samma tema har även hållits i Sverige.

Precis som i Danmark har det även i Finland och Sverige synts en tendens där parternas roll och inflytande i utformningen av arbetsmarknadspolitiken minskat något över tid. I Finland har parterna traditionellt en stark roll, och har varit med om att utforma såväl aktiva som passiva åtgärder $i$ trepartsamarbeten och officiella arbetsgrupper. ${ }^{53}$ Sedan regeringsskiftet 2015 kan man dock skönja en utveckling där ministeriet snarare hör de sociala parterna istället för att som tidigare mer aktivt involvera dem i arbetskraftspolitikens utformning. ${ }^{54}$ Parternas position har också försvagats något av att den regeringen som tillträdde 2015 introducerat lagstiftning inom områden som tidigare reglerats via kollektiva förhandlingar.

Även i Sverige har parternas roll och inflytande vid utformningen av arbetsmarknadspolitiken minskat över tid. ${ }^{55}$

"Vi [Arbetsmarknadsdepartementet] har inget samråd med arbetsmarknadens parter men det är klart att den politiska ledningen träffar dem, med det finns inga fasta arbetsgrupper där dessa parter ingår." (Intervju med Jarefors \& Löw, myndighetshandläggare på Arbetsmarknadsdepartementet)

Arbetsmarknadens parter har dock en roll som rådgivare till Arbetsförmedlingen. Enligt förordning (2000:628) om den arbetsmarknadspolitiska verksamheten ska verksamheten bedrivas i samverkan med andra aktörer på arbetsmarknaden, däribland arbetsmarknadens parter. Parterna ingår således i Arbetsförmedlingens Partsråd. Partsrådet är ett rådgivande organ på nationell nivå i frågor som rör Arbetsför-

\footnotetext{
${ }^{2}$ Jørgensen 2006; Bredgaard \& Larsen 2009.

${ }^{53}$ Se Ramboll 2012, S, 11, kapitlet "Työvoimapolitiikan suunnittelu työmarkkinaosapuolten ja muiden hallinnonalojen näkökulmasta".

${ }^{54}$ Intervjuer med Arbets- och näringsministeriet.

${ }^{55}$ Intervju Sjöberg \& Olsson, 2015-12-09.
} 
medlingens verksamhet. Inom ramen för projektverksamhet kan Arbetsförmedlingen samverka med parterna och lokala arbetsgivare i utformningen av olika insatser.

"De [Partsrådet] använder vi för att diskutera ett antal frågor som är mer pågående, där vi har beroenden till parterna. Men vi brukar också redovisa årsredovisning, budgetunderlag och verksamhetsplaneringsdokumenten så de har möjlighet att titta på dem och tycka till om dem. Ofta på ett övergripande plan men det kan vara detaljerat. " (Intervju med Mikael Sjöberg, generaldirektör \&

Clas Olsson, biträdande generaldirektör Arbetsförmedlingen)

För övrigt är parternas roll i Sverige framförallt viktig i händelse av varsel via omställningsorganisationerna, som snarare är ett komplement till den statliga arbetsmarknadspolitiken. Något som är unikt för Sverige är de elva så kallade trygghets- eller omställningsorganisationer uppstod genom kollektivavtal mellan parter i olika sektorer och fokuserar på tidiga insatser, till exempel rådgivning och coachning, i samband med varsel till följd av strukturomvandlingar.

I Norge har arbetsmarknadens parter ett informellt inflytande och agerar aktivt genom brev, samråd med mera. Arbetsgivarorganisationer och fackförbund, till exempel Næringslivets hovedorganisasjon (NHO) och Landsorganisasjonen (LO), har rollen som intresseorganisationer och är inte involverade på ett institutionellt plan i NAV. Överenskommelsen om en inkluderande arbetsplats (IA) mellan regeringen, arbetsgivare och arbetstagare innebär en hel del kontakt på arbetsmarknadspolitiska frågor. Detta samarbete institutionaliserades genom inrättandet av arbetsliv- och pensionspolicyrådet under ledning av arbets- och socialministern och där alla de viktigaste organisationer ( 8 organisationer) på arbetsgivare och arbetstagare är representerade. Dessutom har det etablerats arbetsgrupper där parterna ingår som följer upp åtgärder, status och måluppfyllelse i överenskommelsen. NAV är representerat i alla dessa fora. Dessutom är de viktigaste organisationer representerade i arbetet med att designa den ekonomiska politik som också lägger ramarna för arbetsmarknadspolitiska program.

Även om samarbetet med parterna är informellt på ledningsnivå och centralt i myndigheten har NAV-kontoren konkreta samarbeten med parterna lokalt. NAVkontoren har ofta etablerat samarbete med enskilda företag på lokal nivå kring rekrytering, praktikplatser och liknande som i sin tur förutsätter att parterna är överens och tar ansvar. Det finns också mer informella samarbeten lokalt och även regionalt med NAV Fylke för att säkerställa en samsyn kring hur sysselsättningsmålen ska uppnås. 



\section{Styrning av arbetsmarknadspolitik i de autonoma regionerna}

Hittills har fokus varit på de fem stora länderna i Norden och hur styrningen av arbetsmarknadspolitiken ser ut. I detta kapitel vänds blickarna mot de tre autonoma regionerna. Eftersom de på många sätt skiljer sig sinsemellan och från de övriga länderna presenteras här varje region för sig. Organisering och styrning av arbetsmarknadspolitiken, olika styrmekanismer, parternas och kommunernas roll täcks dock in hos respektive region. De reformer som gjorts i de autonoma regionerna behandlas, liksom för övriga länder, i kapitel sju. Källor för den information som presenteras nedan är intervjuer som gjorts i respektive region, samt dokument och litteratur om regionernas arbetsmarknadspolitik och styrning. För en fullständig källförteckning, se kapitel 10.

\subsection{Färöarna}

På Färöarna har man valt en helt unik lösning för att styra den aktiva arbetsmarknadspolitiken, som saknar motsvarighet i något annat nordiskt land. På Färöarna är ALS ensamt ansvarig organisation för både aktiveringsåtgärder, det vill säga arbetsförmedling, arbetsmarknadsutbildning, rådgivning med mera, samt för arbetslöshetsförsäkringen. Det unika är dock att ALS är så fristående från statsapparaten i övrigt.

ALS bildades i samband med en ekonomisk kris på Färöarna 1992. ALS ägs av en stiftelse, som är finansierad till lika delar av arbetstagarorganisationer och arbetsgivarorganisationer, samt ett engångsbelopp som betalades ut av Staten när ALS bildades.

Styrelsen har sju ledamöter som utses av den ansvarige ministern:

- Tre medlemmar att representera arbetsgivare. Två av de tre har utsetts att representera privata arbetsgivare, medan en representerar offentliga arbetsgivare. 
- Tre medlemmar för att representera arbetare. De 30 fackförbund som finns på Färöarna kan göra nomineringar, bland vilka den ansvarige ministern utser tre. En medlem representerar timanställda, en representerar fiskeriarbetare och en representerar anställda i allmänhet.

- Den sjunde medlemmen utses av den ansvariga ministern och denna person är också ordförande för styrelsen.

Nedan är ett organisationsdiagram för ALS:

Figur 19: Organisationsdiagram ALS

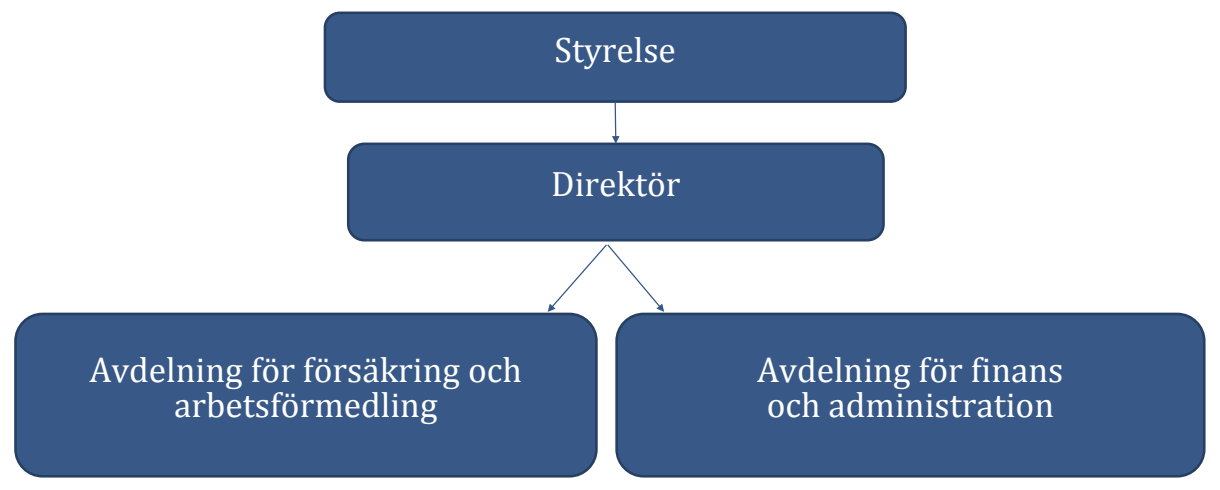

Det är styrelsen som utser direktören för ALS. ALS har en mycket långtgående autonomi. Eftersom det är en stiftelse står det utanför statsbudgeten, och är därmed fritt från budgetförhandlingar och annan inblandning från politiker. Der er ikke instanser/aktører på det færøske arbejdsmarked, der i samme grad overvåger beskæftigelsesindsatsen som i de øvrige Nordiske lande. ALS er uden for det færøske Finanslov og er derfor ikke en del af den offentlige rigsrevision eller tilsyn. På så sätt har staten överlåtit en betydande del av arbetsmarknadspolitiken på arbetsmarknadens parter, som i praktiken är ansvariga för ALS.

Den ansvariga ministern för arbetsmarknadsområdet (Hendrik Old - Landsstyremedlem) sätter överordnade mål för den Färöiska arbetsmarknaden, ofta i tätt samarbete med ALS och dess styrelse. I praktiken fungerar styrningen av insatser på så sätt att man överlåter till arbetsmarknadens parter via deras representanter i ALS styrelse att förverkliga den politik som ministern och lagtinget har bestämt. Regeringen och de politiska målen har således en styrande roll på ett övergripande plan, men det är ALS som står för implementeringen och som ofta dessutom fungerar som rådgivande organ i lagstiftningsprocessen, tillsammans med arbetsmarknadens parter. 
Styrmodellen på Färöarna skiljer sig således från övriga Norden, vilket följande citat illustrerar:

Arbejdsmarkedets parter styrer meget mere forholdene end de øvrige Nordiske lande fordi de har deres egne indtægter og administrerer lovgivning og er med til at udarbejde bekendtgørelse og lovgivning. Man kan sige at man har overladt den del til parterne. (Sørin P. Sørensen, Avdelningschef i det Färöiska ministeriet för arbetsmarknad och transport).

ALS är en "one-stop-shop", eftersom de både är ansvariga för aktiveringen av arbetslösa (arbetsförmedling, arbetsmarknadsutbildning och så vidare) och arbetslöshetsförsäkringen.

Alla arbetsgivare och löntagare betalar 1,25 procent av den anställdes lön till systemet för arbetslöshetsförsäkring. Om man blir arbetslös har man rätt till 75 procent av sin lön från arbetslöshetsförsäkringen, dock max 17500 DKK.

För dem som faller utanför ALS är socialförvaltningen (Almannaverkið) ansvarigt för att få dem i sysselsättning. Socialförvaltningen har två typer av stöd till förfogande, försörjningsstöd och revalideringsbidrag. Försörjningsstöd betalas till dem som inte kan försörja sig själva. Man kan även få försörjningsstöd som komplement till ersättning från ALS, om ersättningen från ALS är mycket låg. Reglerna på revalideringsområdet är, som mycket annat inom välfärdsområdet på Färöarna, inspirerat av den danska modellen. Med revalidering menar man stöd till personer som tros ha svårt att hålla sig kvar på eller få en anknytning till arbetsmarknaden. Revalidering är riktat till personer med dokumenterad begränsad arbetsförmåga, till exempel på grund av fysiska eller mentala handikapp eller på grund av sociala omständigheter. Målet är självförsörjning genom en etablering eller återetablering på arbetsmarknaden.

\subsection{Grönland}

Precis som arbetsmarknadens parter har stort ansvar för och autonomi inom arbetsmarknadspolitiken på Färöarna har kommunerna mycket stor inflytande över arbetsmarknadspolitiken på Grönland. Grönlands självstyre (Naalakkersuisut) har dock ett formellt överordnat ansvar, och då genom departementet/ministeriet för näringsliv, arbetsmarknad och handel.

Det är departementet som både utvecklar arbetsmarknadspolitiken och genomför stora delar av sysselsättningsåtgärderna. Förutom departementet har de fyra 
kommunerna på Grönland (Kommuneqarfik Sermersooq, Kujalleq Kommune, Qaasuitsup Kommunia og Qeqqata Kommune ${ }^{56}$ ) också ansvar för implementeringen av arbetsmarknadspolitiken. Medarbetare från departementet besöker alla kommuner med jämna mellanrum.

Under departementet för Näringsliv, Arbetsmarknad \& Handel lyder Majoriaq, vilket har lokala Majoriaq runtom i landet. Majoriaq finansieras gemensamt av kommunerna och utbildningsdepartementet med en ansvarsfördelning där kommunen ansvarar för driften och departementet för att utforma verksamheten. De lokala kontoren fungerar som väglednings- och förberedelsecenter för arbetslösa och andra outbildade på Grönland och fyller en central roll i arbetsmarknadspolitiken och präglas av en "en-dörrs-princip" där man samlat en mängd utbildnings- och arbetsmarknadsfunktioner under ett tak: vägledning och ansökning till utbildning, vägledning till arbete och arbetssökande, som arbetsförmedling samt olika typer av utbildningsverksamhet. Majoriaq finansieras till hälften av kommunerna och till hälften av självstyret via ett årligt driftsbidrag till kommunerna via budgetlagen. Pengarna är till största delen ett fast belopp, och sedan ett rörligt belopp beroende på vilka aktiviteter det lokala centret har arbetat med..$^{57}$

I Sermersooq, som är den största kommunen på Grönland med Nuuk som huvudort, består Majoriaq av 10-12 heltidsanställda. Uppgiften för jobbcentret är att registrera arbetssökanden, administrera utbetalning av ersättning till de ofrivilligt arbetslösa, arbetsförmedling och handlingsplaner för de arbetslösa.

Arbetsmarknadens parter är viktiga samarbetspartner i arbetsmarknadspolitiken på Grönland. Det finns ett nationellt Närings- och arbetsmarknadsråd som består av parterna, de fyra kommunerna, Departementet for Familie, Ligestilling, Sociale Anliggender og Justitsvæsen, Departementet för Uddannelse, Kultur, Forskning og Kirke och Departementet for Erhverv, Arbejdsmarked og Handel samt Finansdepartementet. I rådet diskuteras näringslivets och arbetsmarknadens utmaningar och det diskuteras olika insatser och åtgärder. Rådet möts tre till fyra gånger per år.

Den gällande lagen om arbetsförmedling är från 2014 och bestämmer ansvarsfördelningen för aktiva åtgärder på Grönland. Lagstiftningen ger ramarna för politiken och bestämmer miniminivån för vilka insatser som ska erbjudas i på kommunal nivå (till exempel att förmedlingsinsatser ska göras), men lagen bestämmer ingenting om processen, det vill säga hur det ska göras. Det betyder att kommunerna har breda ramar att

\footnotetext{
${ }^{56}$ Efter kommunsammanslagningen 2009 finns det fyra kommuner på Grönland.

${ }^{57}$ Denna modell har visat sig ha en nackdel, nämligen att stora (och dyra) aktiviteter inte automatiskt leder till större bidrag. Det är därför att införa ett nytt system 2014, där en större del av driftsbidraget är beroende av vilka aktiviteter man anordnat.
} 
röra sig inom och kan utforma de insatser som de tycker bäst passar behoven i kommunen. Med detta sagt finns det ett tätt samarbete och dialog mellan kommunerna och departementet, via telefon, möten, seminarier, kurser med mera. Departementet stöttar också kommunerna på olika sätt, på grund av kommunernas mycket små förvaltningar och att de saknar kompetens och personal inom många områden.

Det finns ingen arbetslöshetsförsäkring på Grönland i klassisk bemärkelse, utan istället betalar kommunen ut ett bidrag som ersättning för inkomstförlust på grund av ofrivillig arbetslöshet.

En stor del av arbetsmarknadsutbildningarna på Grönland är inriktade på råvarusektorn. På Färöarna är på liknande vis mycket av fokus i arbetsmarknadspolitiken riktat mot fiskeindustrin. Detta är en naturlig följd av de autonoma regionernas koncentrerade näringsliv.

\section{3 Åland}

Arbetsmarknadens parter har stort ansvar för arbetsmarknadspolitiken på Färöarna medan Ålands arbetsmarknads- och studieservicemyndighet (AMS) har mycket stort inflytande över arbetsmarknadspolitiken på Åland. Ålands landskapsregering har dock formellt överordnat ansvar, och då genom näringsavdelningen, som årligen antar en verksamhetsplan med närmare inriktning på arbetsmarknadspolitiken i landskapet. Förslaget till plan utarbetas av AMS som på det sättet får inflytande. Arbetslösheten är låg (den har stigit från 2 procent år 2008 till 4 procent 2014, men håller 2015 (3,8 procent) på att sjunka igen). Ålands arbetsmarknads- och studieservicemyndighet (Ams) sköter både den aktiva serviceimplementeringen och skriver bindande utlåtanden till arbetslöshetskassorna. ${ }^{58}$ Det är samma Gent-system som i Finland, det finns inga egna a-kassor på Åland utan det är samma som på fastlandet. Ams ansvarar för administrering och utbetalning av grundpenningen och arbetsmarknadsstödet (som administreras av FPA i Finland) och utför samtidigt de kontroller som krävs för att

\footnotetext{
${ }^{58}$ Fram till 1.1.2016 fanns en "Arbetskraftskommission" ansluten till Ams, som hade som uppgift att bevilja, betala ut och återkräva arbetslöshetsförmåner och skrev bindande utlåtanden till kassorna. Denna tillsattes av landskapsregeringen för två kalenderår i sänder. Kommissionen bestod av en ordförande och fyra eller sex övriga medlemmar. Som ordförande fungerade myndighetschefen för Ams. De övriga medlemmarna, av vilka två eller tre företrädde arbetsgivarna och två eller tre arbetstagarna, samt deras ersättare utsågs på förslag av de mest representativa lokala arbetsmarknadsorganisationerna. (Landskapslag om Ålands arbetsmarknads- och studieservicemyndighet). Arbetskraftskommissionen avskaffades genom en lagändring som trädde i kraft 1 januari 2016. Detta var endast av praktiska orsaker, ej ett politiskt motiverat beslut (enligt intervju med Lundberg).
} 
fastställa de sökandes behörighet till ersättning enligt lagen om utkomstskydd för arbetslösa (de kontrollerna görs i Finland av AN-byråerna).

Kommunernas roll på Åland är att de tar emot arbetssökande i olika former av arbetsträning, praktik och subventionerad anställning, men de har ingen formell (lagstadgad) roll inom arbetsmarknadspolitiken. Kommunerna på Åland har ett lagstadgat ansvar att arrangera arbetsverksamhet för arbetslösa i rehabiliteringssyfte vilket är en aktiv arbetsmarknadsinsats men erkänns formellt som en del av kommunernas ansvar inom ramen för socialtjänsten. Denna insats finansieras av kommunerna tillsammans med landskapet.

Det finns en kontinuerlig dialog mellan landskapsförvaltningen och Ams. Amschefen är inviterad till interna chefsmöten på näringsavdelningen, och den info som kommer från landskapsregeringens ledningsgrupp skickas också till Ams ledning. Det finns även en informell grupp som kallas "arbetsmarknad och studier", som består av tjänstemän från AMS landskapsregering som jobbar med lagberedning på området. Har tidigare varit av ad hoc-karaktär, som sammankallats när det finns något särskilt att ta ställning till, men ska nu börja träffas fortlöpande.

Det är 19 personer på Ams som jobbar med arbetsmarknadsfrågorna (Ams sköter även studiestöd). Verksamheten är organiserad i vägledarteam, förmedlarteam, åtgärdsgruppen och andra specialgrupper där myndighetschefen och/eller bitr. myndighetschefen kan delta.

Ams har ett verksamhetsställe som är beläget i Mariehamn så det finns inte behov för särskilda kontorschefer. Det finns därmed inte fler nivåer i systemet än den mellan Landskapsregeringen och Ams. De uppgifter och befogenheter som enligt lagen om utkomstskydd för arbetslösa ligger på AN-byråerna, har på Åland alltid legat på Ams och sedan årsskiftet ligger även den tidigare Arbetskraftskommissionens uppgifter direkt på Ams (se fotnot föregående sida).

Det finns slutligen ett rådgivande - lagstiftat - organ som heter "Rådgivande delegation för Ams", som landskapsregeringen tillsätter. Detta är inget beslutsorgan utan har endast en rådgivande funktion. Den rådgivande delegationen ska biträda AMS och fungera som ett informations- och kontaktorgan mellan arbetsgivare, arbetstagare, studerande, AMS och landskapsregeringen. I delegationen ingår representanter från arbetsmarknadens parter, Ålands näringsliv, utbildningssektorn på Åland, landskapsregeringen (från utbildnings- och kulturavdelningen och näringsavdelningen) och Kommunförbundet. 


\section{Centralisering och decentralisering i Norden}

Det finns i de nordiska länderna skillnader mellan på vilken nivå makten över arbetsmarknaden ligger, hur strikt styrningen är och hur denna förändrats över tid. Det kan också finnas en skillnad mellan den formella decentraliseringen och den faktiska autonomin på lokal nivå, vilket Weishaupt visat i sin studie "Central steering and local autonomy in PES" (2014). Vikten av en balans mellan lokal autonomi för att kunna uppfylla lokala behov å ena sidan och mellan likvärdighet i hela landet för rättvisa men också effektivitet i åtgärder är noga studerat i den teoretiska forskningen ${ }^{59}$ För att analysera effekten av olika reformer, vilka ofta har berört en rörelse längs med centralisering - decentraliseringsskalan, kommer vi i detta kapitel att studera hur arbetsmarknadspolitiken är organiserad i Norden med avseende på just centralisering och decentralisering. Effekter av eventuella reformer berörs endast kort i detta kapitel, eftersom det sedan är fokus i kapitel sju.

\subsection{Förändring av decentralisering över tid}

Graden av centralisering/decentralisering har i Norden påverkats av olika reformer, från olika utgångspunkter och i olika riktningar. Sedan slutet på 1990-talet har det i Danmark, Island, Norge och Sverige skett strukturförändringar på arbetsmarknaden med decentralisering/centralisering av makten som följd, till att öka kommunernas makt i Danmark och Norge och till att öka statens makt på Island och i Sverige.

I och med strukturreformen i Danmark år 2007 lades den statliga arbetsförmedlingen ner och dess ansvar flyttades till kommunerna och de nyetablerade jobbcentren. Resultatet blev en form av centraliserad decentralisering då själva strukturreformen också innebar färre kommuner (från 271 till 98), bildandet av fem ${ }^{60}$ nya reg-

\footnotetext{
${ }^{59}$ Se till exempel: Mosley 2011 "Decentralisation of public employment services" PES to PES dialogue Analytical Paper, July 2011 och Mosley 2012 "Accountability in Decentralised Employment Service Regimes" OECD Local Economic and Employment Development (LEED) Working Papers 2012/10.

${ }^{60}$ Inom arbetsmarknadspolitiken är det i realiteten fyra regioner.
} 
ioner som ersatte de tidigare 14 amten och därmed en möjlighet för strategisk kontroll över den kommunala implementeringen från centralt håll och från arbetsmarknadsministern. Ett av motiven bakom decentraliseringen var dock att öka avståndet mellan arbetsförmedlingen och ministern. ${ }^{61}$ Reformen 2007 sågs från ministeriet och centrala administrations perspektiv som ett gyllene tillfälle att göra en strategisk inverkan på de lokala myndigheternas implementering. Nya förvaltnings- och genomförandemekanismer godtogs av de lokala myndigheterna som det pris som fick betalas för att få ta över hela sysselsättningsområdet ${ }^{62}$

NAV-reformen i Norge år 2005 innebar en sammanslagning av den statliga arbetsmarknadsmyndigheten och socialförsäkringsmyndigheten till en gemensam statlig myndighet integrerad på lokal nivå med delar av kommunens socialtjänst genom lagar och avtal. Allt samlades inom NAV som etablerades år 2006. Själva arbetsförmedlingen via NAV-kontoren sker dock genom ett likvärdigt partnerskap mellan stat och kommun. Kommunerna fick därmed en roll i en större samlad organisation av arbetsmarknaden.

Det innebär en unik lösning där den statliga och kommunala portföljen är samordnad på lokal nivå, se mer om det nedan. Som nämnts har de lokala NAVkontoren en relativ stor autonomi att utforma arbetsmarknadspolitiken efter lokala behov, genom det partnerskap som finns mellan kommuner och stat. På senare år har dessutom två förändringar skett av styrningen av NAV som båda påverkar decentraliseringen. Dels har styrningen blivit mindre detaljerad, ett arbete som också ska fortsätta framgent. Målet är att NAV-kontoren ska bli mer "myndiga". ${ }^{63}$ Dessutom ska antalet NAV-kontor bli färre för att öka kontorens genomslagskraft på den lokala och regionala nivån. ${ }^{64}$

På Island innebar etableringen av en statlig arbetsförmedling (Arbetsdirektoratet) år 1997 ett statligt övertagande av kommunernas tidigare ansvar för registrering och förmedling av arbetslösa. Innan 1997 ansvarade fackföreningarna för utbetalningar av arbetslöshetsförsäkringar. I Sverige flyttades också makt från den lokala och regionala nivån till staten i och med etableringen av Arbetsförmedlingen år 2008. Fram till nyligen har också Arbetsmarknadsdepartementet detaljstyrt Arbetsförmedlingen väldigt långt.

I strävan efter att säkerställa en välfungerande arbetsmarknad gjordes i Finland en reform 2013 som innebar en hopslagning av de då 74 lokala arbetsmarknadskontoren till de nuvarande 15 regionala arbets- och näringsbyråerna (AN-byråerna). Paral-

\footnotetext{
${ }^{61}$ Larsen (2011).

${ }^{62}$ Caswell \& Larsen (2015)

${ }^{63}$ Intervjuer med Åsholt, samt lokala företrädare för NAV.

${ }^{64}$ Intervju med Åsholt, ASD (2016) NAV i en ny tid - for arbeid og aktivitet. Meld. St. 33 (2015-2016). Melding til Stortinget.

Arbeids-og Sosialdepartementet.
} 
lellt med dessa sammanslagningar har även andra reformer haft bäring på arbetsmarknadspolitikens upplägg. År 2006 etablerades Servicecenter för arbetskraften (TYP), en samservice mellan kommunerna (i första hand social- och hälsovårdsförvaltningar), Folkpensionsanstalten och arbets- och näringsbyråerna, med uppdraget att underlätta integrationen av långtidsarbetslösa på arbetsmarknaden. Sedan 2016 förutsätts att alla kommuner är med i motsvarande verksamhet, som numera går under namnet Sektorsövergripande samservice. År 2015 etablerades KEHA-centren som en nätverksbaserad byrå med uppdrag att producera utvecklings- och förvaltningstjänster för NTM-centralerna samt AN-byråerna. Syftet med KEHA var att centralisera och effektivisera en del av den förvaltning som tidigare legat på de enskilda ANbyråerna och NTM-centralerna. Reformer görs också för att öka kommunernas roll i implementeringen av politiken, dock strikt reglerat och ekonomiskt styrt av staten. Till exempel var ett mål med bildandet av samservicekontoren TYP att öka kommunernas intresse för arbetskraftspolitiken och aktiveringen av arbetslösa. Staten har dessutom i samma syfte fört över kostnaden för arbetslöshetsförsäkringarna till kommunerna för dem som är arbetslösa i mer än 300 dagar.

Den regionala nivån spelar en viktig roll för arbetsmarknadspolitiken i samtliga nordiska länder. I Finland, Island, Norge och Sverige ligger ansvaret för implementeringen av arbetsförmedlingsverksamheten helt eller delvis på den regionala nivån. I Finland finns de 15 regionala AN-byråerna, på Island har den statliga Arbetsförmedlingen åtta regionala kontor samtidigt som det finns 15 serviceområden. I Norge är NAV uppdelat i de 19 fylkena ${ }^{65}$ och i Sverige ligger Arbetsförmedlingens operativa förmedlingsverksamhet fördelad på tre regioner med egna direktörer.

Finland skiljer sig från de andra nordiska länderna eftersom AN-byråerna inte har någon centralförvaltning, istället styrs den regionala implementeringen direkt av den centrala ministernivån. I Finland är det de regionala NTM-centralerna som har ansvar för den regionala utvecklingen. På regional/lokal nivå finns också Delegationer för arbetskrafts- och företagsservice kopplade till de regionala kontoren som rådgivande samverkansorgan som ska guida den lokala implementeringen av arbetsmarknadspolitiken.

Direktörerna för Arbetsförmedlingens regionala kontor i Sverige ingår i en ledningsgrupp som rapporterar till generaldirektören för Arbetsförmedlingen som i sin tur tillsammans med representanter för arbetsgivare och arbetstagare ingår i Partsrå-

\footnotetext{
${ }^{65}$ I till exempel Vest-Agder fylke i Norge är NAV indelat i tre regioner enligt intervju med Egil Lindekleiv och Martin Vestergård, NAV Vest-Agder, Seniorrådgiver og rådgiver (29.10.2015). Liknande system finns också i andra fylken. Regionerna samordnar de lokala kontoren inom regionen men detta är ett frivilligt system och finns därför inte i alla fylken. Genom regionerna kan kontoren samordna och specialisera sig, men syftet är också att service till arbetsgivare och arbetssökanden kan ske över kommun- och fylkesgränser. Det återstår att se om detta upplägg förändras i och med att antalet NAVkontor ska bli färre.
} 
det, som är ett rådgivande organ på nationell nivå i frågor som rör Arbetsförmedlingens verksamhet. ${ }^{66}$ I Danmark koordineras bland annat arbetsmarknadsinsatser och verksamhetsinsatser av de åtta regionala arbetsmarknadsråden (RAR), vilka består av arbetsmarknadens parter.

Den lokala nivån har i Danmark och Norge ansvaret för den aktiva arbetsmarknadspolitiken. I Danmark har kommunerna ansvaret för arbetsförmedlingen och i Norge drivs NAV-kontoren av ett likvärdigt partnerskap mellan staten och kommunerna. Den lokala nivån i de övriga nordiska länderna ansvarar formellt för passiva arbetsmarknadsinsatser, framförallt i form av försörjningsstöd eller delansvar för arbetslöshetsersättningen. Dock innebär detta inte att kommunerna saknar en roll i heller i den aktiva arbetsmarknadspolitiken, vilket vi återkommer till under rubrik 5.3 nedan.

\footnotetext{
${ }^{66}$ Arbetsförmedlingens Årsredovising 2014
} 
Figur 20: Centralisering och decentralisering över tid

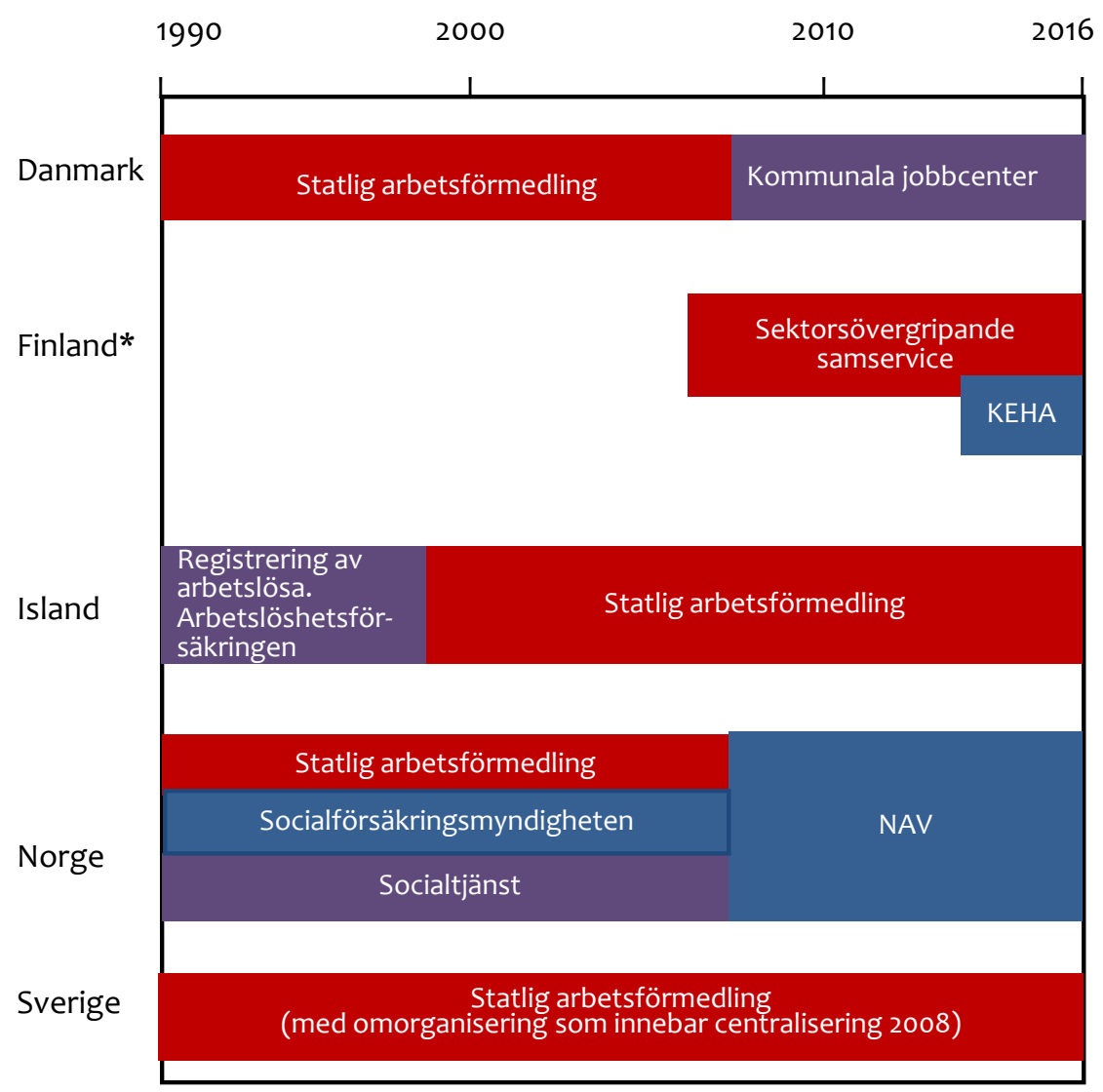

Note: *I Finland har en del andra reformer skett som indirekt kan påverka centraliseringsnivån, till exempel skapandet av NTM-centraler 2010 där det regionala ansvaret för arbetsmarknadspolitik bakades ihop med andra politikområden. På departementsnivå slogs arbetsmarknadspolitiken ihop med näringsdepartementet 2007-2008.

Tendensen bland de Nordiska länderna är centralisering av organiseringen av arbetsmarknadspolitiken. Även i Danmark där kommunerna ansvarar för implementering av den aktiva arbetsmarknadspolitiken motverkas decentraliseringen via ökad strategisk kontroll från arbetsmarknadsministern och statligt håll samt via mål- och resultatstyrning. Generellt har det i Norden blivit färre aktörer och mer strömlinjeformad organisering av styrning. Trots denna trend tillåts mer autonomi för kontoren (som vi sett för NAV och lokala kontor inom svenska Arbetsförmedlingen). Mer om utrymmet för lokal autonomi presenteras i nästa avsnitt. 


\subsection{Styrning på lokal nivå}

För att undersöka hur arbetsmarknadspolitiken implementeras på lokal nivå har ett antal intervjuer gjorts med företrädare på lokala kontor inom arbetsförmedlingen, det vill säga inom respektive myndigheter för public employment service. I regel har intervjuer med både lokala förmedlare, samt kontorschefer gjorts. Intervjuer har också gjorts i både stad och landsbygd i respektive land. I kombination med andra intervjuer är hela styrkedjan täckt, från departement, till ledning för ansvarig myndighet, till regionala och lokala chefer och ut till arbetsförmedlare.

Intervjuerna ger en bild av hur de nationella och centrala styrsignalerna sipprar ned till lokal nivå, och vad som eventuellt händer med intentionerna i styrsignalerna längs med vägen. Intervjuerna säger också något om handlingsutrymmet för att anpassa servicen inom arbetsmarknadspolitiken på lokal nivå efter lokala behov och förutsättningar. Slutligen säger intervjuerna också något om utmaningar inom systemet och hur dessa hanteras.

Nedan beskrivs hur den nationella styrkedjan tar sig uttryck på lokal nivå, hur digitalisering förändrar vardagen på kontoren, samt vilken typ av service och vilken typ av målgrupp som tar mest tid för lokala handläggare. Utvecklingen har på många sätt varit parallell i de nordiska länderna. Styrningen har blivit mindre fokuserad på detaljer och aktiviteter och mer fokuserad på resultat och mål, digitalisering har förändrat arbetsförmedlingens arbetssätt och fokus har skiftat mellan dem som står nära och dem som står långt ifrån arbetsmarknaden, vilket beskrivs nedan.

\subsubsection{Styrkedjan}

De intervjuer som genomförts visar hur styrsignalerna omvandlas på lokal nivå. Det upplevs i Danmark som att det ständigt är nya reformer:

\footnotetext{
"Men du spurgte jo om reformer inden for de seneste ti år, og vores liv her er jo fyldt med reformer. Reformliderligheden der har været de seneste mange år, fordi man hele tiden strammer ind og strammer ind." (Kommunal jobcenter-anställd).
}

Det upplevs i Danmark ändå som att det finns möjlighet att anpassa servicen till individen efter vad medarbetaren själv bedömer som effektivt baserat på erfarenhet och professionalitet: 


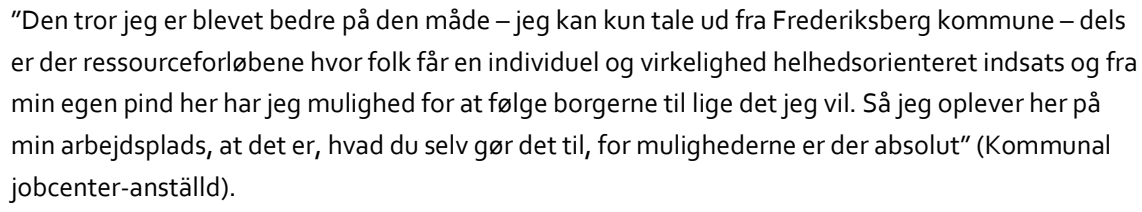

En ansvarig chef för ett jobcenter-kontor som vi har intervjuat menar också att det är relativt lite som styrs från centralt håll, och därmed en stor möjlighet till lokal anpassning. Den kommunala chefen menar att när det gäller det processuella, hur länge det ska gå innan ett samtal, om a-kassan ska meddelas, vilka administrativa system som blir aktuella och så vidare, är mycket styrt. Men vad gäller vilka insatser man väljer finns en hög grad av autonomi och utrymme för den individuella anställdes professionalitet. Men, för att komplicera bilden har man i Danmark de senaste åren minskat de enskilda anställdas frihetsgrad, enligt de intervjuer som har genomförts i denna studie. Det har varit en följd av ökade inslag av performance management av de anställda och nya försök till evidensbaserad praktik för hur till exempel ett samtal bör genomföras. Vikten av mer standardiserade och professionella metoder i samtal har framhållits bland annat av Carsten Koch-utredningen. Graden av frihetsgrad för de anställda kan dock fortfarande variera i stor utsträckning mellan olika kommuner.

På Island har välfärdsministeriet kraftigt ökat bemanningen i lokala arbetsförmedlingar efter krisen och i samband med de initiativ som då startades, inom exempelvis arbetsmarknadsutbildning. ${ }^{67}$ Det som annars utmärker Island i jämförelse med övriga Nordiska länder är det stora inslaget av flexibilitet och informella kontakter på kors och tvärs genom systemet. Detta lyfts fram både på lokal och central nivå. Dessutom upplevs autonomin ha ökat under det senaste decenniet, enligt intervjuer med anställda inom det isländska systemet. Ett exempel på att aktörerna på regional nivå kan utforma egna initiativ är att de regionala arbetsmarknadsråden (vinnumarkaðsráð) har en budget på 2 miljoner isländska kronor per region att lägga på egna projekt som kan bidra till högre sysselsättning i den regionen.

Finland och Norge präglas av tämligen komplicerade styrkedjor, men på olika sätt. I Finland är det en stor mängd olika aktörer inblandade, medan det i Norge sker inom NAV. I Finland till att börja med är NTM-centraler och KEHA-kontor mellanled mellan stat och lokala arbetsförmedlare i AN-byråerna. Som nämnts ovan styrs ANbyråerna delvis direkt av ministeriet, delvis av NTM-centralerna och delvis av KEHAcentret. Dessutom har arbetsmarknadens parter ett stort inflytande. NTM-centralerna ska samordna arbetsmarknadspolitiken på regional nivå och vara ett mellanled mellan

\footnotetext{
${ }^{67}$ Nám er vinnande vegur och Ungt folk till athafna nämns som arbetsintensivt exempel.
} 
ministeriet och AN-byråerna. NTM-centralerna har också många andra arbetsuppgifter och kan därmed bidra till att arbetsmarknadspolitiken samordnas med andra politikområden. Av intervjuerna framgår att det på regional nivå (NTM- och AN-byrånivå) finns goda förutsättningar till regional anpassning, men på lokal nivå upplevs det som att anpassningsförmågan försämrats i och med att en hel del har centraliserats till regional nivå. Exempelvis fanns det mer kontakter mellan den lokala byrån och lokala arbetsgivare förut och det uppstod mer personliga kontakter, medan det nu sker på den regionala nivån där det är mer formaliserat. ${ }^{68}$

I Norge är de lokala NAV-kontoren ledda av både staten och kommunen, vilket leder till en komplex styrkedja. Detta lyfts fram som komplicerat i samtliga intervjuer. På vissa kontor innebär det även delat ledarskap:

"[D]et er to ledere på kontoret, en statlig og en kommunal leder. Mange av styringssignalene fra stat og kommune sammenfaller. Men: i dag kommer det to signaler, via kommunene og via NAV fylke. Det er litt rart at vi har to styringsbrev, istedenfor ett. Det er litt hovedutfordringen i de store byene, hvor kommunen selv har et ganske stort styringsapparat. Småkommunene retter seg mer etter staten. Her er ikke kommune og stat ikke helt enige. F.eks. kommunen ønsker færre på sosialhjelp, da ønsker de å få de over på ytelser (statlig)". (Enhetschef på lokalt NAV-kontor)

Denna utmaning tas även upp av kunskapsdirektören på NAV, Yngvar Åsholt:

Vi skal jobbe i et partnerskap, men styringen er ulik i den kommunale og statlige delen. Dette har vært en underliggende utfordring hele veien med NAV-reformen. (Yngvar Åsholt)

Den kommunala ledningen uppfattas av lokalt anställda som personberoende i hög grad. När kommunens rådman bytts ut har det påverkat verksamheten i NAV, och det upplevs som en bristande kontinuitet eftersom detta har skett ofta. ${ }^{69}$ Vissa utmaningar med den komplexa styrkedjan i Norge verkar dock bli mindre med tiden, och detaljstyrning har också minskat över tid. Det leder till en större autonomi för de lokala NAVkontoren.

I Finland uttrycker en chef på en AN-byrå att arbetsförmedlarna har för mycket personlig frihet för egna bedömningar, vilket leder till godtycklighet och att personer med samma behov kan få olika insatser beroende på vilken anställd personerna hamnar hos. Samtidigt upplever lokala chefer att autonomin har minskat, vilket gör att Finland går emot den trend som finns i övriga länder om ökad autonomi (i ett mer centraliserat system):

\footnotetext{
${ }^{68}$ Intervjuer med anställda på AN-byråer och NTM-centraler på skilda platser i Finland.

${ }^{69}$ Enligt anställd i kommunal del av NAV.
} 
De självständiga byråerna har ju mist autonomi. Besluten gör av ett mindre antal förmän än tidigare. Så där har man mist möjligheten att besluta om saker och ting. Chefernas sitter någon annanstans än tidigare. Men det har ju alltid varit toppstyrt inom den här förvaltningen. Det kommer från regeringen till ministeriet till ELY till TE - man är van med att det är styrt någonstans ifrån. Men vissa saker kunde man bestämma själv på byrån förut som bestäms någon annanstans nu. Man måste fråga uppåt. Men tanken var ju att det skulle vara koncernstyrt - att det ser lika ut i hela landet. För att nå det så krävs det ju central styrning. (Chef för lokal AN-byrå)

Detta citat och övriga intervjuer pekar på att pendeln mellan principen om likvärdig service oavsett plats och principen om lokal autonomi för att anpassa efter lokala förutsättningar i Finland har rört sig från autonomi (om än begränsad) i riktning mot likvärdighet. Detta har också påpekats i nationella utvärderingar. ${ }^{70}$

I Sverige har detaljstyrningen minskat från politiskt håll samt från myndighetens ledningsnivå vilket har bidragit till mer lokal autonomi. Styrkedjan från Arbetsmarknadsdepartementet, via generaldirektör för Arbetsförmedling och lokala chefer till den enskilda arbetsförmedlaren har blivit mindre detaljerad, vilket samtliga intervjuer med alla delar i kedjan också bekräftar. Det var tidigare väldigt styrt vem som kunde få vilken insats, men nu är det mer en fråga för den egna bedömningen ${ }^{71}$, vilket upplevs som en stor förbättring. Arbetsförmedlingen använde tidigare målkort som var mycket aktivitets- och detaljstyrande, medan det nu är mer fokus på resultat och övergripande mål. ${ }^{72}$

\subsubsection{Vilka grupper lägger arbetsförmedlare sin tid på?}

De arbetsförmedlare som har intervjuats har fått resonera om vad som fyller deras tid, vilka målgrupper som är mest tidskrävande. Många har också kommit in på hur intensivt arbetet är, och vilken typ av kontakt förmedlaren har med kunden. Det visar sig då att:

- I samtliga länder läggs det tid på nyanlända och långtidsarbetslösa, och generellt dem som står långt från arbetsmarknaden.

- Nya reformer och nya styrsignaler från ledningen är arbetskrävande och det tar lång tid innan de sitter.

\footnotetext{
${ }^{70}$ Työpolitiikan palvelurakennearviointi: Työpolitiikan palvelurakenteen ohjaus ja kolmikantayhteistyö. Valmisteluryhmän raportti TEM/1165/00.04.03/2013, s.19.

${ }^{71}$ Intervju med lokalt anställd arbetsförmedlare.

${ }^{72}$ Intervju med chef för arbetsförmedlingskontor.
} 
- Antalet arbetssökanden per person varierar kraftigt mellan länder, men också mellan regioner inom länder och beroende på vilka målgrupper den anställde arbetar med.

I samtliga länder är det en pågående diskussion hur nära de olika ersättningssystemen och de sociala insatserna ska vara sysselsättningsinsatser. I Danmark menar de lokala företrädarna att man har ett gott samarbete med socialrådgivare, och de är också ofta samlokaliserade. Ändå är det de fall som är på gränsen mellan sociala ärenden och arbetsmarknadsåtgärder som tar absolut mest tid för de jobbcenter-handläggarna. Merparten av tiden läggs på de som står långt från arbetsmarknaden.

Vi bruger mest tid på dem, der er rigtig svære at få fat i og på dem, hvor arbejdsmarkedsperspektivet er rigtig rigtig småt. Dem bruger vi sindssyg meget tid på. Vi har diskuteret, om vi burde vende bøtten om og bruge mere tid på de lavt hængende frugter i stedet og tage dem, hvor der er en effekt lidt hurtigere. For os ville det ikke være til det ordinære arbejdsmarked, men dem der fx var oplagte til fleksjob. Skulle man pille dem ud og arbejde mere koncentreret med dem, og så lade de andre ligge lidt - selvfølgelig med de fire lovpligtige samtaler om året, og så egentlig ikke gøre så meget mere ved dem, for dermed at få mere tid til de andre. Det er sådan noget "Job i Fokus" fx handler om her, for vi bruger voldsomt meget tid på de mest udsatte. Men det er jo også det, der har været meldt ud politisk de senere år. At vi skulle prøve at få alle med på arbejdsmarkedet (Kommunalt jobcenter-anställd).

Nyligen har man i Danmark infört ett "kontanthjælpsloft" (bidragstak) i Danmark, som enligt intervjuerna med de lokala jobcentermedarbetarna också tar mycket tid. Det gäller även 225-timersregeln, som stipulerar att de som är på kontanthjälp eller arbetslöshetsförsäkring ska arbeta minst 225 timmar per år för att kunna behålla sin ersättning. Man har också slopat möjligheten till förtidspension, vilket gör att personer omprövas regelbundet.

I Finland är de anställda på AN-byråerna "låsta" inom sina respektive servicelinjer. Det finns i regel tre servicelinjer med olika målgrupper beroende på hur nära arbetsmarknaden den arbetssökanden är. Problemet, enligt en intervjuad chef på AN-byrå, är att det är svårt att flytta personal och brukare mellan de olika linjerna, och att systemet därför blir tungrott.

På Island genomfördes flera stora initiativ på kort tid efter finanskrisen. Arbetslösheten steg under kort tid från 1 till 9 procent De nya insatserna innebar en stor ökning i arbetsbörda för de anställda, som var tvungna att erbjuda nya åtgärder till ett mycket stort antal människor. De målgrupper som idag tar upp mest tid för de anställda är dels nyanlända, dels långtidsarbetslösa.

Arbetsförmedlare i Sverige upplever en pressad situation med väldigt många arbetssökanden per person: 
Antal beror på vad man jobbar med. Jag som jobbar på utvecklingsgarantin ska ha lite färre. Ledningen har kanske krav på 100-120 men vi ligger på minst det dubbla. Det finns säkert något mått men i och med att vi alltid ligger över det får vi inte höra det. (Arbetsförmedlare).

Det är svårt att jämföra arbetsbelastningen mellan länder, eftersom olika personers målgrupper kan vara olika komplexa. De danska arbetsförmedlare som intervjuats har mellan 30 och 60 arbetssökanden per person, vilket således är mycket färre än i Sverige. På Island varierar det mellan olika målgrupper, men totalt sett är genomsnittet omkring 190-200 arbetslösa per rådgivare, det vill säga högt i en nordisk jämförelse. I Norge uppges antal brukare per anställd variera stort mellan olika NAV-kontor, runt 50-70 i mindre kommuner, till cirka 200 per anställd i Oslo. I Finland, precis som i Sverige, upplevs arbetsbelastningen som orimligt hög för de enskilda arbetsförmedlarna, med olika mått och indikatorer som ska uppnås på individnivå, enligt de intervjuer som gjorts i denna studie.

Intressant i Sverige är också att flera intervjuade beskriver ny ledning i myndigheten som dels en stor förändring, dels resurskrävande. Den nye generaldirektören har nya och andra prioriteringar som det lokala kontoret måste anpassa sig efter. Generaldirektören Mikael Sjöberg har initierat ett stort förändringsarbete, ${ }_{1}^{73}$ som bland annat innebär ett större fokus på arbetsgivarkontakter. Det är sällan något alla arbetsförmedlare arbetar med, utan ofta är det särskilda team som har utåtriktade aktiviteter och besöker arbetsgivare. Styrsignalen från generaldirektören, så som den har tolkats av en lokal arbetsförmedlingschef, är att femtio procent av kontorens tid ska gå till arbetsgivarkontakter. Annars är det även i Sverige nyanlända och långtidsarbetslösa som kräver mycket tid för arbetsförmedlarna.

\subsection{Kommunernas roll på arbetsmarknaden}

Kommunernas roller i Norden ser generellt sett olika ut, beroende på skiftande kapacitet och storlek. I Danmark finns (sedan reformen 2007) 98 kommuner, i Finland 317 efter en serie sammanslagningar, Island har 74 kommuner, Norge 428 och Sverige har 290 till antalet. Antalet invånare i snitt per kommun varierar från drygt $4000^{74}$ på Island till nära 57000 i Danmark. Det finns därmed stora olikheter i kommunernas kapa-

\footnotetext{
${ }^{73}$ Intervju med Mikael Sjöberg.

${ }^{74}$ Den största kommunen i Reykjavik drar upp snittet Det finns på Island flera kommuner med färre än 100 invånare. Den minsta kommunen, Árnesheppur, har 54 invånare.
} 
citet länderna emellan. Med detta i åtanke ska vi nu undersöka vad kommunernas roll inom arbetsmarknadspolitiken är.

Jämfört med de andra länderna i Norden är Danmarks arbetsmarknadspolitik mindre toppstyrd och själva arbetsförmedlingen är delegerad till kommunerna. Fördelat på 98 kommuner finns totalt 94 kommunala arbetsförmedlingar som har $\mathrm{i}$ ansvar att genomföra aktiva arbetsmarknadsinsatser. Här finns variationer mellan kommunerna där vissa kommuner outsourcar stora delar av genomförandet till andra aktörer. I sådana fall har kommunerna en skyldighet att övervaka att dessa aktörer efterlever de regler och bestämmelser som finns. Kommunernas efterlevnad av lagar och regler övervakas av Styrelsen for Arbejdsmarked og Rekruttering (STAR). STAR ser också till att de arbetslösa står till arbetsmarknadens förfogande och erbjuder kommunerna kunskap, råd och vägledning om de mest effektiva insatserna. För att kommunernas insatser ska gå i linje med den statliga arbetsmarknadspolitiken styrs de ekonomiskt av staten, där återbetalningen för vissa insatser är större än andra. Vad gäller konkreta arbetsmarknadsinsatser har kommunerna stort självbestämmande men ekonomiska incitament används för att styra kommunernas insatser. Även om implementeringen av Danmarks arbetsmarknadspolitik är förhållandevis decentraliserad är styrningen centraliserad genom styrnings- och implementeringsmekanismer som resultatrevision, benchmarking och effektmätningar.

I resten av Norden är arbetsförmedlingen centralt administrerad och kommunernas roll i förverkligandet av arbetsmarknadspolitiken handlar främst om delaktighet i olika samarbeten samt ansvar för passiva arbetsmarknadsinsatser. Kommunerna i Finland, Island och Norge har tydliga samarbeten med staten. I Finland samarbetar kommunerna med AN-byråerna som har i ansvar att implementera arbetsmarknadspolitiken och som styrs strikt av Arbets- och Näringsministeriet. Kommunerna i Finland har också ett lagstadgat ansvar att arrangera arbetsverksamhet för arbetslösa i rehabiliteringssyfte vilket är en aktiv arbetsmarknads-insats men erkänns formellt som en del av kommunernas ansvar inom ramen för socialtjänsten. Denna insats finansieras av kommunerna tillsammans med staten. Kommunernas roll är annars begränsad till passiva arbetsmarknadsinsatser och de har ett delat ansvar att finansiera arbetslöshetsbidrag för långtidsarbetslösa. Även om kommunernas lagstadgade ansvar för sysselsättningen är begränsad bedriver många kommuner ofta olika typer av arbetsmarknadsåtgärder på eget initiativ. Sedan 2004 har kommunerna varit involverade i utvecklandet av så kallade Servicecenter för arbetskraften (TYP), som sedan 2016 går under namnet Sektorsövergripande samservice som främjar sysselsättningen. Dessa är en samservice för tjänster för långtidsarbetslösa, där kommunen, arbets- och näringsförvaltningen och Folkpensionsanstalten erbjuder sina kunder tjänster som nätverk, och varje nätverk har åtminstone ett gemensamt serviceställe. Nätverken verkar på lokal nivå och den operativa ledning- 
en av varje nätverk ansvaras av en person utsedd av nätverkets kommuner. Verksamheten har tidigare byggt på aktörernas ömsesidiga avtal men sedan 2015 är verksamheten lagstadgad och omfattar hela landet. Enligt en chef på ett NTM-center innebär den nya lagen utökat samarbete mellan NTM-centraler, AN-byråer och kommuner:

Lagen tvingar oss att samarbeta med kommunen kring TYP. Om lagen inte fanns så skulle samarbetet mellan kommunen och AN-byråerna inte vara så stark och djup. Men TYP-lagen har tvingat oss till samarbete, vilket är bra för de här kunderna behöver verkligen mer än bara arbetspolitiska tjänster. Även hälsovård och sociala tjänster i många fall. Men processen är tung och dyrbar så tvåtre organisationer samarbetar med samma kund och det kostar såklart mycket. Främjar kunderna i sista hand men processerna är tung och dyrbar. (Chef på NTM-central).

Kommunerna på Island har ett regionalt ansvar för arbetsmarknadsfrågor samt socialtjänstfrågor i samarbete med och strikt styrt av Välfärdsministeriet. Kommunerna har ett speciellt samarbetsavtal med Arbetsdirektoratet (Vinnumálastofnun) och är dess viktigaste samarbetspartner. Samarbetsavtalet tillkom efter att tidsramen för arbetslöshetsersättning förkortades 2015. Kommunerna kan medfinansiera arbetsmarknadsinsatser och båda parter kan initiera samarbete. Större kommuner erbjuder också sina invånare regionala arbetsmarknadsinsatser utanför samarbetet med Arbetsförmedlingen. Kommunerna ansvarar för utbetalningen av socialbidragen och anställer personer från arbetslöshetsförsäkringssystemet.

I Norge finns ett samarbetsavtal mellan landets 428 kommuner och NAV (Arbeidsog velferdsetaten) som har i ansvar att förvalta både aktiva och passiva arbetsmarknadsinsatser. Tillsammans med NAV driver kommunerna NAV-kontoren som är den första kontaktpunkten för de som efterfrågar aktiva insatser och de som söker om dagepenger eller andra stöd. NAV-kontoren kan ha kommunalt och/eller statligt tillsatta chefer och styrs genom rapporteringskrav till staten. NAV-kontoren rapporterar också på månadsbasis till kommunerna om arbetsmarknaden och arbetsmarknadsinsatser. Kommunernas utbetalningar av socialbidrag sker via NAV-kontoren men dessa värderas inte som reella arbetsmarknadsinsatser eftersom de skiljer sig från andra passiva insatser som till exempel dagepenger vilka finansieras av staten genom NAVförvaltning som har ansvaret för de passiva arbetsmarknadsinsatserna.

Många kommuner äger så kallade attføringsbedrifter, eller yrkesinriktade rehabiliteringscenter, från vilka NAV köper tjänster. Dessa är organiserade som oberoende bolag.

Norsk lag förutsätter att det lokala NAV-kontoret ska informera lokalpolitiker om faktorer som kan öka eller upprätthålla sociala problem i kommunen, i syfte att den lokala beslutsprocessen ska hantera problemen. Många NAV-kontor tolkar detta som ett utrymme för en aktiv roll för det lokala kontoret, och kan då ta ansvar för bland annat att koordinera insatser mot skola, lokala vårdinrättningar, barnomsorg, med mera. 
Kommunerna i Sverige har ett visst formellt ansvar som ligger utanför den statliga arbetsmarknadspolitiken. Varje kommun ska enligt lag vidta eller på annat sätt främja åtgärder för att förebygga arbetslöshet eller minska verkningarna av arbetslösheten, och många kommuner har därför egna arbetsmarknadspolitiska program som riktar sig till mottagare av försörjningsstöd, ett stöd som kommunerna betalar. I viss mån har kommunerna varit missnöjda med hur Arbetsförmedlingen verkat. Till följd av förändringar av kvalificeringsreglerna inom arbetslöshetsförsäkringen mot slutet av gotalet och vidare åtstramningar 2007 har antalet mottagare av försörjningsstöd ökat över tid. Denna förändring har påverkat kommunernas praktiska roll inom arbetsmarknadspolitiken. Katarina Thorén, universitetslektor vid Stockholms universitets institution för socialt arbete som forskat om arbetsmarknadspolitik och kommunala arbetsmarknadsåtgärder, beskriver kommunernas förändrade roll så här:

\footnotetext{
"Försörjningsstödet ökade väldigt markant för kommunerna, det var en mycket dyrare kostnad för personer som i princip var arbetslösa, man hade ingen större social problematik utan man var arbetslös. Då började kommunerna anordna egna typer av åtgärdsprogram som motprestation för att få försörjningsstöd. [...] Den stora gruppen var ganska många människor som hade försörjningsstöd som primär försörjningskälla. I många kommuner skapades det en parallellverksamhet till Arbetsförmedlingen. [...] Här ville kommunerna ha lite kontroll över de deltagarna som de så att säga hade i sin budget." (intervju med Katarina Thorén)
}

För att minska antalet mottagare av försörjningsstöd genomför numera många kommuner egna insatser som mottagarna behöver ta del av. I kommunernas parallellverksamhet till Arbetsförmedlingen ingår exempelvis jobbtorg, matchningsverksamheter och andra kommunala motsvarigheter till Arbetsförmedlingens verksamhet. I de stora kommunerna ligger numera arbetssökarbiten på arbetsmarknadsförvaltningen snarare än på socialtjänsten och socialförvaltningen.

En gemensam nämnare för kommunernas roll i Norden är att även om det inte finns formella krav på kommunerna att genomföra aktiva arbetsmarknadsinsatser sker detta många gånger på kommunernas egna initiativ eftersom de ansvarar för ekonomiskt stöd till arbetslösa i form av försörjningsstöd, har ett ansvar för sina arbetslösa invånare eller ett ansvar för en viss grupp av arbetslösa som till exempel långtidsarbetslösa. Som tidigare nämndes i avsnittet om styrning via ekonomiska incitament har från statligt håll ökade utgifter för kommunernas passiva arbetsmarknadsinsatser i Finland, Island och Sverige lett till ökad kommunal involvering i aktiveringen av arbetslösa för att minska utgifterna för passiva arbetsmarknadsinsatser. I Finland har kommunerna fått ta över kostnaden för arbetslöshetsförsäkringar från staten för de som varit arbetslösa en längre tid och på Island och i Sverige har kommunernas 
utbetalningar av försörjningsstöd ökat till följd av att färre är berättigade stöd från arbetslöshetsförsäkringen.

Utöver kommunernas roller vad gäller arbetsmarknaden skiljer sig rollen i relation till staten där kommunerna i Danmark, Finland, Island och Norge har en tydligt definierad relation till staten till skillnad från kommunerna i Sverige. Denna relation till staten skiljer sig mellan kommunerna i Danmark som driver arbetsförmedlingen, kommunerna i Norge som driver arbetsförmedling i likvärdigt partnerskap med staten, till kommunerna i Finland och Island som har olika formaliserade roller på arbetsmarknaden och i arbetsförmedlandet. På Island har kommunerna en horisontell relation till staten och den statliga arbetsförmedlingen vad gäller samarbeten även om arbetsmarknaden är toppstyrd. I Sverige däremot finns få samverkansytor mellan kommunerna och staten till följd av centraliseringen som följde med bildandet av Arbetsförmedlingen 2008. Detta är något som nu håller på att åtgärdas och till exempel har kommunerna numera ett samverkansuppdrag med Arbetsförmedlingen vad gäller myndighetens etableringsuppdrag för nyanlända. Så här uttryckte sig Arbetsförmedlingens generaldirektör Michael Sjöberg och biträdande generaldirektör Clas Olsson om kommunens förändrade roll gentemot Arbetsförmedlingen:

"Arbetsförmedlingen har under en period varit styrd mot att nästan inte samverka med kommunerna, utan att fokusera inåt. Jag tror vi är helt eniga om internt att vårt uppdrag är så komplext att vi bara kan lösa det i samverkan med andra aktörer och kommunerna är viktig i många av dem. De sitter ju på arbetsmarknadssystem och egna arbetsmarknadsresurser. De har också näringslivskontakter.[...] Vi har fått igång ett bra samarbete, känslan är bra där ute, men det kommer att ta flera år innan vi ser om det betyder något för våra resultat. ${ }^{175}$

\subsection{Kommunernas roll i styrning och samarbeten}

I samtliga av de nordiska länderna ingår kommunerna i kommunala samarbetsorganisationer tillsammans med till exempel regioner och län: Kommunernes Landsforening $(\mathrm{KL})$ i Danmark, Finlands kommunförbund, Samband islenskra sveitarfélaga på Island, KS i Norge och Sveriges kommuner och Landsting (SKL). Dessa representerar kommunernas intressen men har olika roller i styrningen.

KS i Norge har en formaliserad arena för dialog med regeringen. Årligen har de flera fasta möten som leds av kommunal- och regionalministern där bland annat ramar, eko-

${ }^{75}$ Sjöberg \& Olsson, Arbetsförmedlingen, intervju 2015-12-09 
nomi och service inom kommunsektorn diskuteras. KS har en formell relation till staten i strävandet efter visionen om en självständig och nyskapande kommunsektor.

Även Kommunernes Landsforening (KL) i Danmark har en formell roll i politiken. $K L$ representeras med fyra medlemmar av de 26 medlemmarna i Beskæftigelsesrådetrådet (BER) som ger råd till beskæftigelsesministern i frågor gällande exempelvis politiska förslag om ökad sysselsättning, projekt, utvecklingsprogram, uppföljningar och arbetsmarknadspolitiska lagförslag. KL försöker säkra största möjliga kommunala självstyre genom att försvara de danska kommunernas gemensamma intressen och genom att försöka påverka den lagstiftning och de incitament som reglerar kommunernas insatser. Inom KL samarbetar kommunerna kring arbetsmarknadsinsatser och de har haft ett projekt där de etablerade ett partnerskap för styrningen av arbetsmarknadsinsatser där politiker och toppämbetsmän i samspel med experter och $\mathrm{KL}$ skulle inspireras till att utveckla den politiska styrningen och arbetsmarknadsinsatserna i kommunerna. ${ }^{76}$ Till skillnad från de andra länderna representerar $\mathrm{KL}$ endast primärkommunerna medan Danmarks fem regioner ingår $i$ intresseorganisationen Danske Regioner.

På Island har kommunerna en roll i styrningen av arbetsmarknadspolitiken via den kommunala centralorganisation, Association of Local Authorities (Samband islenskra sveitarfélaga). Dessa hanterar kollektiva förhandlingar och representerar alla kommuner i den aktiva arbetsmarknadspolitiken, Centralorganisationen är också representerat i styrelsen av Arbetsdirektoratet.

I Finlands Kommunförbund ingår kommunerna, städerna, landskapsförbunden, sjukvårdsdistrikten, specialomsorgsdistrikten och de kommunalt anknutna organisationerna inom utbildning och andra områden.

Kommunförbundet i Finland och Sveriges Kommuner och Landsting (SKL) i Sverige har en liknande roll på arbetsmarknaden, nämligen att vara stöd för sina medlemmar och skydda deras intressen dock utan att ha en formell arena för att påverka politiken.

I Danmark, Island och Norge har kommunerna via centralförbunden och formella arenor makt att påverka politiken och skydda sina egna intressen. Att skydda kommunernas intressen och påverka politiken är även något som Finlands Kommunalförbund och Sveriges Kommuner och Landsting gör dock utan en formell kanal.

${ }^{76}$ Kommunernes Landsforening, Politisk partnerskab - styrning af beskæftigelseindsatsen, tillgänglig via: http://www.kl.dk/Kommunale-opgaver/Beskaftigelse/Kontanthjalp-og-starthjalp/Politiske-partnerskab/ 
Tabell 1: Kommunala centralorganisationer

\begin{tabular}{|c|c|c|}
\hline Land & Kommunal centralorganisation & Roll \\
\hline Danmark & Kommunernes Landsforening (KL) & $\begin{array}{l}\text { Intresse- och medlemsorganisation för alla kommuner i } \\
\text { Danmark. }\end{array}$ \\
\hline Finland & Finlands Kommunförbund & $\begin{array}{l}\text { Intresse-, utvecklings- och serviceorganisation för alla } \\
\text { kommuner i Finland. }\end{array}$ \\
\hline Island & $\begin{array}{l}\text { Samband íslenskra sveitarfélaga } \\
\text { (Association of Local Authorities) }\end{array}$ & $\begin{array}{l}\text { Samarbetsorganisation. Enligt lag representant för landets } \\
\text { kommuner och regioner. Arbetar nära staten. }\end{array}$ \\
\hline Norge & $\begin{array}{l}\text { KS (The Norwegian Association of } \\
\text { Local and Regional Authorities) }\end{array}$ & $\begin{array}{l}\text { Arbetsgivar- och intresseorganisation. Har en formaliserad } \\
\text { arena för dialog med regeringen om ramar och mål inom } \\
\text { kommunsektorn. }\end{array}$ \\
\hline Sverige & $\begin{array}{l}\text { Sveriges Kommuner och Landsting } \\
\text { (SKL) }\end{array}$ & $\begin{array}{l}\text { Arbetsgivar- och intresseorganisationer. Medlemsorganisation } \\
\text { för alla kommuner, landsting och regioner. }\end{array}$ \\
\hline
\end{tabular}

Det är inte bara genom de kommunala centralorganisationerna som kommuner $\mathrm{i}$ Norden har en roll i arbetsmarknadspolitiken, i flera av de nordiska länderna ingår kommunerna dessutom i olika samarbeten. ${ }^{77}$ Kommunerna i Finland är också involverade i politiken genom sin roll i den så kallade Sektorsövergripande samservice ${ }^{78}$ som främjar sysselsättningen. Denna samservice är en samordningsplattform för arbetsmarknadspolitiken genom vilken samarbetet mellan stat och kommun har stärkts. Kommunernas roll och ansvar regleras av lagen men den varierar i praktiken mellan kommunerna, i och med olika grader av frivilliga sysselsättningsåtgärder som bl.a. bedrivs i projektform. Under de senaste åren har kommunerna i ökad grad finansierat och medverkat i sysselsättningsprojekt för bland annat unga och långtidsarbetslösa. De större kommunerna har generellt en mer samordnad strategi för arbetsmarknadspolitiken jämfört med de mindre.

Kommunerna på Island ingår i ett samarbetsavtal med Arbetsförmedlingen. Staten har till ansvar att försäkra regelbundna formella samarbeten med kommunerna i frågor som rör dem.

\footnotetext{
${ }^{77}$ Vaikeimmin työllistyvien työvoima- ja yrityspalvelujen järjestämisvastuun siirto valtiolta kunnille http://www.kunnat.net/fi/asiantuntijapalvelut/aek/tyollisyys/eriava-mielipide/Sivut/default.aspx

${ }^{78}$ Finska kommuners sysselsättningsskyldighet; Statsrådets förordning om offentlig arbetskrafts- och företagsservice (31 \$ Sysselsättningsförfarande. Arbets- och näringsbyrån ska informera den sysselsättningsskyldiga kommunen om kommunens sysselsättningsskyldighet. Av sysselsättningsanmälan ska framgå grunden för sysselsättningsskyldigheten, den utbildning och arbetserfarenhet som den som ska sysselsättas har samt övriga uppgifter som behövs med tanke på sysselsättandet.)
} 
Vissa av Sveriges kommuner ingår i samordningsförbund tillsammans med Försäkringskassan, Arbetsförmedlingen och hälso- och sjukvården. Samordningsförbundens uppdrag är att genom gemensamma medel och projekt vidta samordnade rehabiliteringsinsatser för bland annat människor som är sjukskrivna. Kommuner som deltar bidrar med en fjärdedel av medlen.

I Norge sker lokal samordning mellan NAV, kommunerna och VOX (Nasjonalt fagorgan for kompetansepolitikk) vad gäller invandrares utbildning. ${ }^{79}$ Denna samordning är frivillig och sker med stora lokala variationer. De norska kommunerna koordinerar också regionråd inom områden de har samarbeten, dock är dessa inte direkt knutna till arbetsmarknadspolitiken. Det har dock förekommit att regionråden protesterat mot nationella nedskärningar $\mathrm{i}$ anslagen för arbetsmarknadspolitiska program i regionen och som motreaktion begärt en ökad finansiering av regeringen. ${ }^{80}$

\subsection{Kommunernas roll i förändring}

Från och med 2007 har kommunerna i Danmark ansvaret för både passiva och aktiva arbetsmarknadsinsatser genom de kommunala arbetsförmedlingarna. Kommunerna övertar därmed ansvaret för de försäkrade arbetslösa (dagpengemodtagere) och aktiveringen av dem. Kommunerna övertar också utgifterna, men staten återbetalar (refunderer) en stor del av dessa utgifter. Denna förändring i arbetsmarknadssystemet innebär att arbetsförmedlingen kan genomföra sammanhängande och målinriktade arbetsmarknadsinsatser. I Danmark trädde en ny refusionsreform i kraft den 1 januari 2016, som påverkar kommunernas roll. Reformen innebär som nämnts att kommunernas underhållskostnader ersätts av staten på grundval av de resultat som kommunerna producerar snarare än vad kommunerna gör. Det finns en risk att en sådan förändring fokuserar på de arbetslösa som är lättast att få in på arbetsmarknaden. Kommunernas ansvar har dock blivit större eftersom alla arbetslösa numera ska vara aktiva och ha sysselsättning som mål samt en plan för att nå det målet. Å ena sidan innebär reformen att kommunerna kommer att ha större incitament att få medborgare i arbete, eftersom det nu kan vara en större andel av den kommunala utgifter som inte nödvändigtvis helt täckta. $\AA ̊$ andra sidan innebär reformen att det finns färre regler för kommunerna, eftersom det inte längre är någon skillnad i graden av ersättning mellan olika tjänster och åtgärder.

\footnotetext{
${ }^{79}$ VOX, Hvordan få innvandrere i jobb? (16.02.2015) http://www.vox.no/nyheter/Hvordan-fa-innvandrere-i-jobb/

${ }^{80}$ Salten regionråd, SR-sak 08/11c Uttalelse vedr. reduksjon av tiltaksplasser for yrkeshemmede med behov for arbeidsrettet bistand i skjermet sektor i Nordland (11.02.2011).

http://www.salten.no/sites/s/salten.no/files/28606123a58cf1ddoc8fb4ag8b86b372.pdf
} 
Tidigare har det funnits en indelning av arbetslösa i aktiva och passiva, för vilken den sistnämnda gruppen inte hade som mål att få sysselsättning:

"Det har været en vigtig del at gå fra at sige, det område handler om at sikre folks forsørgelse, det her område handler at få folk hurtigt ud i arbejde. Det var det statement, der var på vej. Og det betyder noget for at kommunerne har incitament til at der er flere, der skal i arbejde. At folk skal hurtigst muligt i arbejde, så slipper vi også for betjene en andel af deres forsørgelse. ${ }^{\prime{ }^{81}}$ (Intervju med Bendixen, $\mathrm{KL}$ )

Finlands kommuner har påverkats av reformer som sökt att öka deras intressen för arbetsmarknadspolitiken samt aktiveringen av arbetslösa. Sedan 2006 har kommunerna gradvis fått ett större ansvar för arbetslöshetsersättningen. För dem som är arbetslösa i mer än 300 dagar står kommunerna för hälften av arbetslöshetsersättningen och 70 procent av arbetslöshetsersättningen för dem som är arbetslösa mer än 1000 dagar. Det senaste årtiondet har kommunernas kostnader för arbetslöshet ökat vilket lett till att framför allt större städer påbörjat utvecklingsprojekt. Majoriteten av aktiva arbetsmarknadsåtgärder är dock fortfarande statens ansvar. Kommunerna har också fått ett delansvar i modellen med Sektorsövergripande samservice som främjar sysselsättningen (tidigare Servicecentren för arbetskraften (TYP)) för personer som står långt ifrån arbetsmarknaden. Detta har lett till ett bättre samarbete mellan staten och kommunerna. Den regering som tillträdde år 2015 har även gjort en utredning om att överföra ansvaret för arbetsmarknadsinsatser för dem som står längst bort ifrån arbetsmarknaden till kommunerna, enligt den danska modellen. ${ }^{82}$ I nuläget ser det dock ut som att dess förslag inte kommer att verkställas. Kommunernas framtida roll $i$ sysselsättningspolitiken är fortfarande något oklar i och med att Finland står inför en stor förvaltningsreform, den så kallade Vård- och landskapsreformen. ${ }^{83}$

Till skillnad från Finland har kommunerna på Island fått minskat ansvar jämfört med staten till följd av reformer. I och med etableringen av Arbetsförmedlingen 1997 tog staten över registreringen av arbetslösa från kommunen. Staten tog också över utbetalning av arbetslöshetsförsäkringen från a-kassorna. I början av 2016 beslutade

\footnotetext{
${ }^{81}$ Intervju med Kristina Bendixen, KL.

${ }^{82}$ Statsrådets kansli (2015). Lösningar för Finland. Strategiskt program för statsminister Juha Sipiläs regering 29.5.2015. Regeringens publikationsserie 11/2015. http://valtioneuvosto.fi/documents/10184/1427398/Ratkaisujen+Suomi_RUOTSI_YHDISTETTY_netti.pdf/159cf517-d936493c-8e47-b52912a8f824

${ }^{83}$ Avsikten är att en regeringsproposition om reformens slutliga utförande lämnas till riksdagen i slutet av 2016. http://alueuudistus.fi/framsida
} 
Välfärdsministeriet, Arbetsdirektoratet och kommunerna om ny rollfördelning för arbetsmarknadsinsatser för funktionshindrade.

I Norge har kommunernas roll påverkats av en organisatorisk sammanslagning av den statliga arbetsmarknadsenheten. NAV-reformen 2005 innebar en sammanslagning av den statliga arbetsmarknads- och socialförsäkringsmyndigheten i ett organisatoriskt partnerskap med delar av den kommunala socialtjänsten syftande till att samla alla relevanta verksamheter för att få folk i arbete under samma organisation. I och med denna reform ingick kommunen i ett likvärdigt partnerskap med staten genom NAV-kontoren vilket stärkte kontakten mellan stat och kommun.

Den arbetsmarknadspolitiska reformen i Sverige 2008 innebar liksom reformen på Island en centralisering av makten. Numera finns ett fokus på samverkan med kommuner för att reparera detta och sedan 2015 finns i Sverige en nationell överenskommelse mellan Arbetsförmedlingen och Sveriges Kommuner och Landsting som ska skapa en förutsägbar, tydlig och långsiktigt hållbar samverkan. De arbetsmarknadspolitiska förändringarna gällande A-kassa har dessutom haft en indirekt effekt på kommunerna vars utbetalningar av försörjningsstöd har ökat och som följd har kommunerna skapat egna arbetsmarknadsinsatser. Alla kommuner i Sverige hade tidigare arbetsmarknadsnämnder, och det finns således en viss tradition av att även kommunerna tar ansvar för matchningen lokalt. Det är av stort intresse för kommunen att göra det, för att säkerställa att det lokala näringslivet och den offentliga sektorn får tag i arbetskraft, helst kvalificerad eller behörig sådan. Det gäller i synnerhet mindre kommuner. Kommunernas engagemang är därför inte isolerat till att begränsa kommunens utgifter (för försörjningsstöd etc.) utan det handlar också om näringslivets överlevnad och den offentliga servicens möjlighet att tillfredsställa kommuninnevånarnas behov. Många kommuner gör ett ambitiöst arbete med att försöka hantera det som arbetsförmedlingen många gånger misslyckas med.

Kommunernas roller på Nordens arbetsmarknader har ändrats från att de fått mer ansvar framförallt i Danmark och Norge vad gäller arbetsförmedling men också i Finland vad gäller aktivering av arbetslösa till följd av ökade utgifter för passiva arbetsmarknadsinsatser. 
Tabell 2: Kommunernas förändrade roll

\begin{tabular}{|c|c|c|c|}
\hline & $\begin{array}{l}\text { Formellt ansvar } \\
\text { kommunerna fått }\end{array}$ & $\begin{array}{l}\text { Formellt ansvar } \\
\text { kommunerna tappat }\end{array}$ & $\begin{array}{l}\text { Informellt ansvar som } \\
\text { kommunerna tagit }\end{array}$ \\
\hline Danmark & $\begin{array}{l}\text { - Arbetsförmedling via } \\
\text { Jobbcenter } \\
\text { - Aktivering även av passiva } \\
\text { arbetslösa }\end{array}$ & & \\
\hline Finland & $\begin{array}{l}\text { - Delat ansvar för finansie- } \\
\text { ringen av arbetshetslös- } \\
\text { hetsersättningen för de } \\
\text { som varit arbetslösa i mer } \\
\text { än } 300 \text { dagar } \\
\text { - Delansvar i Sektorsöver- } \\
\text { gripande samservice som } \\
\text { främjar sysselsättningen, } \\
\text { samt organisera aktiva } \\
\text { arbetsmarknadsinsatser för } \\
\text { arbetslösa med låg anställ- } \\
\text { ningsbarhet. }\end{array}$ & & $\begin{array}{l}\text { - Större städer har påbörjat } \\
\text { utvecklingsprojekt till följd av } \\
\text { ökade utgifter }\end{array}$ \\
\hline Island & & $\begin{array}{l}\text { - Registreringen och för- } \\
\text { medling av arbetslösa }\end{array}$ & $\begin{array}{l}\text { - Några större kommuner har } \\
\text { egna arbetsmarknadsinsatser } \\
\text { (både i samarbete med Ar- } \\
\text { betsförmedlingen och utanför } \\
\text { detta samarbete) }\end{array}$ \\
\hline Norge & $\begin{array}{l}\text { - Likvärdigt partnerskap } \\
\text { med staten i drivandet av } \\
\text { NAV-kontoren } \\
\text { Men forsatt ansvars- och } \\
\text { arbetsdelning }\end{array}$ & $\begin{array}{l}\text { - En separat kommunal } \\
\text { socialförvaltning (denna är } \\
\text { numera en del av NAV) }\end{array}$ & \\
\hline Sverige & & & $\begin{array}{l}\text { - Aktiva arbetsmarknadsin- } \\
\text { satser för bidragstagare, till } \\
\text { följd av utökade utgifter av } \\
\text { försörjningsstöd }\end{array}$ \\
\hline
\end{tabular}





\section{Reformer och utveckling över tid}

\subsection{Reformer av styrning och organisering}

Samtliga nordiska länder har under de senaste tio åren genomgått större förändringar vad gäller arbetsmarknadssystemens administrativa styrning och organisation. Reformer har genomförts såväl vad gäller servicestrukturens organisering, ekonomiska ersättningssystem, arbetsmarknadspolitiska åtgärder samt prioritering av målgrupper. En gemensam utmaning för samtliga nordiska länder är en åldrande befolkning och minskat arbetskraftsutbud. I de flesta länder har dessa utmaningar tacklats $i$ första hand genom pensionsreformer och övriga sätt att förlänga arbetslivet. Parallellt har en delorsak till flera reformer inom arbetsmarknadspolitiken varit en önskan om att tillvarata outnyttjad arbetskraftspotential och få personer som står utanför arbetsmarknaden i sysselsättning. Många av de arbetslösa är utrikesfödda och personer med långa arbetslöshetstider och matchningen mellan de arbetssökande och de lediga jobben är en utmaning i flera länder.

Nedan redogörs för huvuddragen i de mest betydelsefulla reformerna i organisation och styrning som skett i de nordiska länderna under de senaste tio åren.

\subsubsection{Danmark}

Den institutionella grunden för 2000-talets viktigaste reformer i Danmark lades i samband med reformen "Flere i arbejde" som genomfördes redan år 2002. Denna reform innebar också att den danska arbetsmarknadspolitiken starkt kom att präglas av en aktiveringspolitik då den tidigare arbetsmarknadspolitiken ersattes av en sysselsättningspolitik. Andelen upphandlad verksamhet ökades även markant. Med "Flere i arbejde" var ett av de nya elementen intentionen om en större ivolvering av "andra aktörer" (dvs. olika typer av privata och ideella aktörer) i arbetsmarknadspolitiken. Reglerna kring arbetskraftspolitiska åtgärder harmoniserades och förenklades med utgångspunkten att minska de skillnader i tillgång till arbetskraftspolitiska åtgärder som fanns beroende på om den arbetssökande lyfte arbetslöshetsersättning eller socialbidrag. Genom att förbättra samordningen mellan den 
statliga och den kommunala delen av arbetsmarknadspolitiken ville staten även öka kontrollen över den kommunala sysselsättningspolitiken. ${ }^{84}$

Följande stora steg var den s.k. "Strukturreformen" 2007, en omfattande kommunreform med stor bäring på organiseringen av arbetsmarknadspolitiken. De tidigare 14 länen ( $a m t)$ ersattes då av fem regioner, även om den regionala nivån inom arbetsmarknadspolitiken sköts av fyra beskæftigelsesregioner, och antalet kommuner minskades från 270 till 98. I samband med detta lades Arbejdsformidlingen ned och kommunerna tog över huvudansvaret för arbetsmarknadsinsatser. Det tidigare parallellsystemet där arbetslösa utan arbetslöshetsförsäkring, det vill säga vars ersättning bestod i kontanthjälp (socialbidrag) hörde till kommunernas ansvar, medan den statliga Arbejdsformedlingen ansvarade för dem med arbetslöshetsförsäkring ("dagpengemodtagerne") avskaffades därmed. Orsaken till reformen var farhågor om att bristen på samordning mellan dessa system reducerade effekterna av arbetsmarknadspolitiken, då exempelvis de som stod utanför arbetslöshetsersättningen fortfarande hade en mer begränsad tillgång till aktiva åtgärder än de med ersättning från arbetslöshetsförsäkringen. Insatser för de båda målgrupperna samlades således i samband med reformen, och s.k. jobcenter inrättades. I praktiken kom således målgruppen för de aktiva åtgärderna att utvidgas - allt i enlighet med aktiveringspolitikens målsättningar om att öka arbetskraftsutbudet och att minska den strukturella arbetslösheten. ${ }^{85}$ Åtstramningar har även genomförts i de ekonomiska ersättningarna, med motivering att det skulle öka incitamenten att aktivt söka jobb. Såväl socialbidragstagare som personer med sjukpenning kom att omfattas av en aktivitetsplikt och de aktiva åtgärderna infördes i ett tidigare skede.

Reformen har även inneburit förändringar $\mathrm{i}$ ansvarsfördelning mellan stat och kommunerna. Inledningsvis var ansvaret för jobbcentren i huvudsak delat mellan kommunerna och staten, men 2010 tog kommunerna över hela det operativa ansvaret. Kommuner fick även ett delansvar i finansieringen av arbetslöshetsersättning och i kostnaden för att aktivera arbetslösa med arbetslöshetsersättning. Den organisatoriska reformen innebar således också en ändring i styrningen av arbetsmarknadspolitiken, där ett viktigt inslag var att kommuner fick ökade ekonomiska incitament att både agera mer långsiktigt och att implementera effektiva åtgärder som snabbt leder till sysselsättning. ${ }^{86}$ Ett av reformens centrala mål var att förbättra samverkan mellan arbetsmarknadsåtgärder och övriga kommunala ansvarsområden. Att verka på det

\footnotetext{
${ }^{84}$ Jørgensen, H. (2006), Arbejdsmarkedspolitikken fornyelse - innovation eller trussel mod dansk "Flexicurity", Bruxelles og Aalborg, s. 46, LO \& FTF.

${ }^{85}$ Rockwool Fondens Forskningsenhed, 2013 a.

${ }^{86}$ Intervju med Carsten Koch.
} 
lokala planet möjliggjorde även bättre möjligheter för närmare samverkan med lokala företag och utbildningsanordnare. ${ }^{87}$

Rent politiskt var, enligt forskaren Fleming Larsen, en central tanke bakom överföringen av ansvar från stat till kommun att förflytta kritiserade sysselsättningsåtgärder längre bort från ministeriet. ${ }^{88}$ Samtidigt uppges ministeriets bristande förtroende för den lokala nivån som en orsak till reformerna. Förflyttningen av det direkta ansvaret har därför inte minskat Arbetsmarknadsministeriets kontroll över de kommunala insatserna, utan processen kan snarast beskrivas som en centraliserad decentralisering, där ministeriets politiska ansvar minskat samtidigt som kommunernas insatser i högre omfattning än tidigare styrs från centralt administrativt håll via nye styrinstrument och implementerings-mekanismer såsom refusionssystemet, benchmarking mellan kommuners resultat och resultatstyrning ${ }^{89}$ Kommunerna gavs i och med reformen stor självbestämmanderätt vad gäller de konkreta åtgärderna, men inriktningen på insatserna styrs genom ett ersättningssystem där kommunernas utgifter för arbetsmarknadsinsatser delvis återbetalas av staten. Larsen ${ }^{90}$ beskriver det som en implementering av new public management-principen "steering not rowing", med införandet av en styrning baserad på resultatstyrning, benchmarking, output och outcomemätningar, och tydliga ekonomiska incitament. Tidigare har staten tilldelat kommunerna ersättning på grundval av de insatser som görs, men en utveckling gentemot starkare fokus på resultatstyrning pågår.

I början på 2016 togs ett nytt system i bruk för att ersätta kommunerna för deras utgifter för arbetssökande (Refusionsreformen 2016). Det nya ersättningssystemet har stärkt incitamentstyrningen, genom att ersättningsnivån successivt och märkbart trappas ned över tid, från 80 procent de första fyra veckorna till 20 procent efter ett år. En annan förändring är att ersättningsnivån inte längre är avhängig vilken typ av ersättning den sökande har (tidigare varierade nivån beroende på om den arbetssökande fick socialbidrag, a-kassa eller förtidspension). Detta innebär en förenkling av systemet, men det primära syftet med reformen var dock att ytterligare stärka kommunernas incitament att fokusera på resultat, dvs. att med snabba och effektiva åtgärder få arbetssökande i arbete. Styrningen har sammantaget även gått mot en allt mer evidensbaserad utveckling, där politiska mål ersatts av en strävan efter effektiva åtgärder, med hjälp av utvärderingar och indikatorer som stödjer

\footnotetext{
${ }^{87}$ Oosi, O. (2014) International Peer Review of Labour Policy Service Structures 56/2014.

${ }^{88}$ Larsen (2011).

${ }^{89}$ Larsen (2011), s. 47.

${ }^{90}$ Larsen, F. (2011), Ny beskæftigelsespolitik via administrative reformer? Tidsskrift for arbejdsliv, 13 årg., nr. 4, 2011.

http://www.nyt-om-arbejdsliv.dk/images/pdf/2011/nr4/tfa4_2011_040_055.pdf
} 
kunskapen om hur olika insatser fungerar i praktiken. ${ }^{91}$ Ett viktigt steg i denna riktning skedde i samband med den så kallade "Beskæftigelsesreformen" år 2014. Reformen var politiskt betingad då effektiviteten i den rådande arbetsmarknadspolitiken varit hårt ifrågasatt. Till grund stod således an omfattande utredning av en arbetsmarknadspolitisk expertgrupp under ledning av ordförande i Beskæftigelserådet och tidigare ministern Carsten Koch. Styrningen kom i och med reformen att $\mathrm{i}$ högre grad fokusera på resultat, snarare än regler och processer. ${ }^{92}$ Fokus låg i hög grad på den sökandes rättigheter och skyldigheter, och syftade till att i högre grad ge de arbetssökande individuell och tidig service. Detta var en strategisk förändring som baserade sig på evidens om att tät dialog och kontakt med de sökande underlättar en snabb återgång till arbete. ${ }^{93}$ I praktiken utökades den personliga kontakten mellan kunderna och jobcentret; en arbetssökande blev skyldig att delta i uppföljningsmöten en gång i månaden under de första sex månaderna. Samtidigt förenklades regelverken och digitala tjänster infördes för att lätta på kommunernas administrativa börda. I samband med detta inrättades även STAR, Styrelsen för Arbetsmarknad och Rekrytering, som ersatte de tidigare Arbejdsmarkedsstyrelsen (som haft det överordnade ansvaret för genomförandet och uppföljningen av arbetsmarknadspolitiska insatser i regioner och kommuner) och Styrelsen for Fastholdelse og Rekruttering (vars uppgift hade varit att främja en ökning av arbetskraftsutbudet i Danmark). Inrättandet av STAR syftade till att förtydliga styrningen.

\subsubsection{Finland}

Finland har genomgått ett mer eller mindre ständigt pågående reformarbete av arbetsmarknadspolitiken under en lång tid, karakteriserat av flera mindre justeringar snarare än stora reformer. 2000-talets reformvåg har i första hand inkluderat förändringar $\mathrm{i}$ ansvarsfördelning och introducerandet av nätverkssamarbete mellan myndigheter, ofta föranledda av budgetnedskärningar..$^{94}$ En viktig aspekt har varit att separera insatser mot kortare konjunkturellt betingad arbetslöshet respektive mot mer strukturell långtidsarbetslöshet. I mitten på 2000-talet genomfördes en reform av arbetsmarknadsservicen som innebar; dels en utveckling av arbetskraftsbyråernas service för att effektivisera och möta behoven hos de arbetslösa som är redo att ta emot

\footnotetext{
${ }^{91}$ AMS Denmark, Peer PES Paper; AMS: Host Country PES Issues Paper. The European Commission Mutual Learning Programme for Public Employment Services: 2013.

${ }^{92}$ Buhring, T. (2014) Denmark: New reform targets unemployment. Eurofound 17 December 2014.

${ }^{93}$ Carsten Koch rapport 2014, Intervju med Pernille Harden.

${ }^{94}$ Räisänen, Heikki, forskningsdirektör Arbets- och näringsministeriet, 2015-03-11.
} 
ett jobb, dels inrättandet av s.k. servicecenter för arbetskraften TYP ${ }^{95}$ för personer som står längre ifrån arbetsmarknaden. Som ovan beskrivits är denna samservice, numera formellt kallad Sektorsövergripande samservice som främjar sysselsättningen, ett samarbete mellan arbets- och näringsbyrån, staden/kommunen och Folkpensionsanstalten. Ett centralt mål i reformen var att öka kommunernas engagemang i att aktivera arbetslösa som stod långt ifrån arbetsmarknaden. ${ }^{96}$ Inrättandet av samservicemodellen åtföljdes även av en reform där kommunerna tog över ett delansvar för finansieringen av arbetslöshetsersättning för långtidsarbetslösa.

Även sammanslagningen av Arbetsministeriet, Handels- och industriministeriet och Inrikesministeriets avdelning för region- och förvaltningsutveckling till ett nytt Arbets- och näringsministerium år 2007 var på ett strukturellt plan en väsentlig reform inom arbetsmarknadspolitiken. Syftet med sammanslagningen var att på sikt inom alla nivåer inom förvaltningen öka växelverkan mellan serviceformerna som stödjer företagsamhet och sysselsättning. På så sätt skulle arbetsmarknadspolitiken på ett tydligare sätt kopplas samman med näringslivet och arbetsmarknadens behov. Denna integrering förstärktes något i samband med bildandet av de regionala NTMcentralerna 2010 då ett av centralernas ansvarsområden blev "näringar, arbetskraft, kompetens och kultur". ${ }^{97}$ Följaktligen har även företag blivit en allt viktigare målgrupp för AN-byråerna, vid sidan av arbetssökande..$^{98}$

År 2012 fattade statsrådet ett arbetsmarknadspolitiskt beslut med tre ledande mål: stödjandet av principen om en snabb övergång från ett arbete till ett annat, stödjandet av en kontinuerlig förnyelse av närings- och arbetslivet och tillvaratagandet av hela arbetskraftspotentialen. Som en del i detta reformerades det arbetsmarknadspolitiska servicesystemet, i syfte att skapa en mer kundorienterad och resultatbringande helhet. ${ }^{99}$ Reformen, som trädde i kraft 1 januari 2013 , innehöll en totalrevidering av lagstiftningen kring den offentliga arbetskrafts- och företagsservicen och en förnyelse av AN-byråernas servicenätverk. De tidigare 74 lokala byråerna slogs samman till 15 administrerande byråer, som inrättades inom varje Närings-, trafik- och miljöcentrals område. Dessa regionala arbets- och näringsbyråer (AN-byråer) och deras lokala verksamhetsställen bildade ett nät för arbets- och näringsservicen, tillsammans med den

\footnotetext{
95 Dessa servicecenter utvecklades ursprunglingen ur ett s.k. samserviceförsök redan 2002-2003. Sedan 1.1.2015 är de lagstadgat att sådan samservice som formellt går under namnet "Sektorsövergripande samservice som främjar sysselsättningen" ska finnas över hela landet (Lag om sektorsövergripande samservice som främjar sysselsättningen 1369/2014)

${ }^{96}$ Aho, S. (2007) Basic income support and services for uninsured jobseekers: German and Finnish institutions and reforms compared. Comments and Statements. Available at http://pdf.mutual-learningemployment.net/Downloads/Germany2007/Finland_DE_07.pdf

${ }^{97}$ NTM-centralernas övriga två ansvarsområden är "trafik och infrastruktur" samt "miljö och naturresurser"

${ }^{98} \mathrm{RP} 133 / 2012 \mathrm{rd}$

${ }^{99}$ Statsrådet principbeslut för att säkerställa en välfungerande arbetsmarknad och utbudet av arbetskraft, 31. 5.2012.
} 
ovannämnda sektorsövergripande samservicemodellen. ${ }^{100}$ Samtidigt omformades AN-byråernas servicestruktur till tre tematiska "servicelinjer", som i praktiken utgår i från behovet av stöd för att komma i sysselsättning:

1. Arbetsförmedlings- och företagstjänster, primärt för personer som står närmast arbetsmarknaden.

2. Tjänster för kompetensutveckling, för personer som behöver mer stöd och aktiva insatser för att ta sig tillbaka till arbetsmarknaden.

3. Tjänster för stödd sysselsättning, för personer som står längst ifrån arbetsmarknaden.

Parallellt utvecklades även de digitala tjänsterna och den telefonbaserad servicen, $\mathrm{i}$ första hand som ett komplement till den personliga "face-to-face" servicen.

I samband med reformeringen av servicestrukturen förändrades även styrningen av arbetsmarknadspolitiken i och med att AN-byråerna själva tog över ansvaret för att säkerställa enhetligheten mellan regionerna, ett ansvar som tidigare legat på NTMcentralerna. ${ }^{101}$ NTM-centralernas roll i styrningen kom i huvudsak att fokusera på utveckling. För att göra NTM-centralernas och AN-byråernas administration effektivare, inrättades vid ingången av 2015 NTM-centralernas och AN-byråernas riksomfattande utvecklings- och förvaltningscenter (KEHA-centret). Flera administrativa uppgifter som tidigare legat på AN-byråerna och NTM-centralerna, som personal-, ekonomioch informationsförvaltningsuppgifter koncentrerades till centret. I praktiken har KEHA-centret därmed också kommit att få en roll i styrningen, genom att de antar riktlinjer kring förvaltningsprocesser. På ett övergripande plan har det dock inte skett någon större förändring av styrningen i Finland då landet har en lång tradition av resultatstyrning. Däremot har detaljnivån på återrapporteringen förändrats under 2000talet. Även om detaljerad data om utfallet vid varje AN-byrå produceras av såväl NTM-centralen, Arbets- och näringsministeriet och KEHA-centralen, så följs resultaten inte upp i samma utsträckning som det gjordes genom återrapporteringen i början på 2000-talet. Återrapporteringen till central nivå sker i huvudsak genom NTMcentralernas årsredovisning till ministeriet, men det finns varken positiva eller negativa incitament kopplat till resultatuppfyllelsen. På regional nivå förekommer dock

\footnotetext{
${ }^{100}$ RP $133 / 2012$.

${ }^{101}$ Arbets- och näringsministeriet, Työpolitiikan palvelurakennearviointi: Työpolitiikan palvelurakenteen ohjaus ja kolmikantayhteistyö Valmisteluryhmän raportti. 28.10.2014 .s. 10.
} 
månatliga dialogmöten mellan AN-byrån och NTM-centralen där resultatmålen kan diskuteras som en del i kontinuerlig uppföljning av verksamheten.

Trots diskussioner om bristande ekonomiska incitament har arbetslöshetsersättningen i Finland inte reviderats i samma utsträckning som i de andra nordiska länderna. Framförallt till följd av arbetsmarknadsparternas starka ställning har detta varit en politiskt sett "låst" fråga. Istället för markanta justeringar av ersättningsnivån, har mindre reformer införts i villkoren för ersättning med syfte att öka incitamenten till aktivt arbetssökande. Bland annat ändrades pendlingsregionen till att omfatta ett område som sträcker sig $80 \mathrm{~km}$ från personens boningsort, ersättningen kopplades tydligare till den arbetssökandes skyldigheter i de individuella sysselsättningsplanerna, och AN-byråerna har i högre grad anvisat lediga tjänster till de sökande som dessa måste söka. Möjligheten att ta ett deltidsarbete utan att det påverkar arbetslöshetsersättningen har även förbättrats.

\subsubsection{Island}

Den isländska arbetsmarknadspolitiken under det senaste årtiondet har framförallt präglats av finanskrisen 2008. Den ledde till en betydligt mer markant ökning av arbetslösheten än i övriga nordiska länder, när den steg från 1 till 9 procent. För att bemöta denna utveckling utökades den offentliga arbetsförmedlingens verksamhet, vilket möjliggjordes genom att personalstyrkan på det statliga arbetsdirektoratet (Vinnumalastofnun) utökades kraftigt och nya aktiva åtgärder inrättades i snabb takt.

Island har inte genomgått några större reformer vad gäller arbetsmarknadspolitikens organisation, sedan ansvaret för arbetsmarknadspolitiken år 1997 flyttades från kommunerna till det statliga arbetsdirektoratet. År 2011 slogs flera ministerium samman till ett Välfärdsministerium (Velferðarráðuneytið), som samlade arbetsmarknadspolitik, hälso- och socialpolitik, familje- och jämställdhetspolitik samt migrations- och flyktingpolitik under ett och samma paraply. Motivet till denna sammanslagning var i första hand att minska administrativa kostnader, snarare än ett politiskt strategiskt beslut, och reformen fick därmed ingen faktisk inverkan på arbetsmarknadspolitiken.

1997 reformerades arbetslöshetslagen och statliga arbetsdirektoratet fick ansvar för all administration kring arbetslöshetsförsäkringen. Tidigare hade Island haft ett mer klassiskt Gent-system, där fackföreningarna ansvarat för a-kassorna. I samband med det breddades också arbetslöshetsförsäkringen till att gälla även dem som inte var med i fackföreningar, egenföretagare med flera. Systemet finansieras nu genom sociala avgifter som betalas av arbetsgivarna (tryggingagjald). Idag är i princip samtliga anställda mellan 18-70 år täckta av arbetslöshetsförsäkring. 
Vad gäller servicen till arbetssökande och andra med funktionshinder har den isländska regeringen överfört ansvaret till kommunerna sedan 1 januari 2011. Kommunerna har sedan dess ansvar för implementering och finansiering av service till funktionshindrade utan att Arbetsdirektoratet har med arbetsmarknadsfrågor att göra, även för funktionshindrade. Tanken med reformen var att samla servicen till en aktör, eftersom kommunerna sedan tidigare var ansvarig för anna social service till de funktionshindrade. Dessutom skulle reformen bidra till en tydligare och enklare arbetsfördelning mellan stat och kommunerna.

De reformer som genomförts inom arbetsmarknadspolitiken på 2000-talet har dels föranletts av budgetnedskärningar, dels liksom i andra nordiska länder i syfte att öka de ekonomiska incitamentet till aktivering. Även på Island har rätten till arbetslöshetsersättning tydligare kopplats till krav på aktivt arbetssökande, i samband med reformen 1997, och på 2000-talet har de ekonomiska incitamenten till aktivitet ökats framförallt genom att ersättningsperioden stramats åt, samtidigt som själva ersättningen höjts. År 2006 förnyades flera arbetsmarknadspolitiska lagar, då ersättningsperioden kortades ned från 5 år till 3 år. Därefter har ersättningsperioden ytterligare kortats ned till 2,5 år (1 januari 2015), delvis föranlett av regeringens sparåtgärder. Det pågår även en debatt om huruvida socialbidrag i någon mån bör villkoras. Även andra reformer för att öka arbetslösa individers incitament till aktivering har genomförts, bl.a. kan en arbetslös avbryta sin arbetslöshet för att studera och ifall studierna inte leder till arbete kan individen återgå till arbetslöshetsersättningen på bibehållen nivå.

Även på Island kan man skönja en trend mot ökat fokus på arbetslivsinriktade rehabilitering/revalidering, även om ingen större skiftning i målgruppsorientering skett. I flera omgångar har det gjorts särskilda satsningar på långtidsarbetslösa, med fokus på aktiva åtgärder för dem som utförsäkrats. Överlag har servicen blivit mer individanpassad och utbudet av kurser och program har ökat för att bättre kunna möta den enskilde arbetssökandes behov. Även upphandlad verksamhet har utökats och genom digitalisering har man eftersträvat ökad effektivitet både i den interna administrationen och kundservicen.

Också på Island har arbetsförmedlingen satsat på ökade kontakter med arbetsgivare, för att bättre kunna kartlägga och tillgodose arbetsmarknadens behov. Överlag samarbetar det statliga arbetsdirektoratet i hög grad med andra aktörer, utöver arbetsgivare även med kommunen, arbetsmarknadens parter, utbildningsanordnare och Virk. Även om ingen faktisk "one-stop-shop-modell" har utarbetats, fungerar Vinnumalastofnun i hög grad som en inkörsport till samtliga tillgängliga servicekanaler för arbetssökande.

Vad gäller styrningen har inga större förändringar skett, men en tydlig trend är ett ökat fokus på utvärdering av insatser, där ministeriet i någon mån utökat sina rappor- 
teringskrav gentemot Arbetsförmedlingen. Även det statliga arbetsdirektoratet har i högre grad satsat på utvärdering för att kunna styra sina resurser till de mest effektiva åtgärderna. Denna utveckling kan ändå inte härledas till en uttrycklig målsättning om evidensbaserad politik, utan bottnar även det i finanskrisen då man ville säkerställa att de resurser som användes för att bemöta den snabbt stigande arbetslösheten faktiskt var verksam.

I september 2014 bildade ministern för sociala frågor och boende (den minister på välfärdsministeriet som är ansvarig för arbetsmarknadsfrågor) en styrgrupp för att föreslå förändringar inom arbetsmarknadspolitiken i syfte att åstadkomma ett så högt deltagande på arbetsmarknaden som möjligt. Styrgruppen har formulerat ett antal principer för politiken, ${ }^{102}$ men några faktiska reformerna har ännu inte implementerats, utan det ska ske under de närmaste åren.

\subsubsection{Norge}

I Norge har den år 2005 inledda "NAV-reformen" (Ny Arbeids- og Velferdsforvaltning) utgjort en stor organisatorisk omställning, då tidigare Arbetsförmedlingen (Aetat) och socialförsäkringsmyndigheten (Trygdeetaten) slogs ihop till en myndighet (NAV-etat) och ett partnerskap baserat på samlokalisering inleddes med kommunala socialtjänster. Målet med reformen var att samordna alla väsentliga åtgärder som syftar till få folk i arbete, det vill säga både aktiva och passiva åtgärder, för att underlätta för den enskilde och snabbare kunna utreda den enskilde sökandes behov. ${ }^{103}$ Kommunen och staten behöll således sina respektive ansvarsområden, men en samlokalisering av statliga och kommunala åtgärder syftade till att öka kundfokus, med en målsättning om att lättillgängliga, individanpassade åtgärder med tätare uppföljning skulle effektivisera övergången till arbete. Vid sidan av att samlandet av aktiva och passiva åtgärder inom samma organisation skulle underlätta för brukaren, motiverades sammanslagningen även politiskt med en målsättning om att skapa tätare koppling mellan individens rättigheter och skyldigheter,

\footnotetext{
${ }^{102}$ The steering group's main findings were: Empower the current trilateral partnership between the government and labor market parties. Job participation nationwide should be increased. The labor market should be ready to provide individuals with limited work capacity to work domestically. Provide equal opportunities for foreign nationals in the labor market. Ensure an environment that in the long run contributes to increased well being and health of employees as well as increase the potential for older labor market participants to increase and improve their qualifications. The level of education in the Icelandic labor market should be increase especially in the countryside. Strengthen the connection between the education system and labor markets in primary schools thereby bridging a gap between school and vocation early on. Gender specific education and career selection will be reduced. Labor market participants should not be discriminated against neither directly or indirectly.

${ }^{103}$ Alm Andreassen, T. \& Aars, J. (2015), Den store reformen - Da NAV ble til, Oslo: Universitetsforlaget, 2015.
} 
samt att möjliggöra en enhetlig och tät uppföljning av kunden. Genom att skifta fokus i arbetsmarknadspolitiken från passiva till aktiva åtgärder, ville man således råda bot på ökade kostnader för passiva åtgärder och sjukpensionering och öka och aktivera arbetskraftsutbudet. ${ }^{104}$ "Arbetslinjen" har fått ökat fokus i Norge de senaste 20 åren och var en central del i NAV-reformen. Större fokus lades på långtidsarbetslösa och socialbidragstagare, aktivitetskraven ökade och maxlängden på arbetslöshetsersättningen förkortades. Sammantaget hade reformen ett stort fokus på de arbetssökande kunderna - arbetsgivarperspektivet var däremot inte inkluderat i reformen.

En starkt bidragande orsak till organisationsförändringen var även oklarheter i ansvarsområdet mellan den statliga arbetsmarknadsmyndigheten, socialförsäkringsmyndigheten och kommunernas socialtjänst, vilket gjorde att enskilda individer hamnade mellan stolarna. Reformen var politiskt framdriven av Dagfinn Høybråten (Kristelig Folkeparti) som valde att gå direkt emot rekommendationerna från en extern expertkommission, vilka förespråkade en bibehållen separat organisation för pension och arbetsmarknadsfrågor ${ }^{105}$ Det har påpekats att Høybråtens bakgrund som bl.a. tidigare kommundirektör samt direktör för Kommunenes Sentralforbund (KS) bidrog till att kommunsektorn blev starkt involverad i utformningen av reformen och bidrog till att kommunerna fick en stark plats i NAV-organisationen. ${ }^{106}$

Reformen har karaktär av både NPM och vad man kan kalla post-NPM. NAVreformen karaktäriseras av Post-NPM i synen på samarbete och koordinering som möjliggörspecialisering i enheterna. Staten har standardiserat och säkrat kontroll och en enhetlig styrning över den nya verksamheten. ${ }^{107}$

Reformen har också tecken av New Public Management (NPM); den direkta politiska styrningen har minskat och utvecklingen har gått mot mer mål- och resultatstyrning där varje NAV-kontors verksamhet tätt följs upp genom målkort. ${ }^{108}$ Även det tidigare Aetat präglades dock av resultat- och målstyrning, men karaktären på målen ändrades för NAV. Då Aetat med relativt hög grad av autonomi styrdes av arbets-

\footnotetext{
${ }^{104}$ Meld. St. 33, NAV i en ny tid - for arbeid og aktivitet, s.11 och Arnkil, R., Karjalainen, V., Saikku,P., Spangar, T., Pitkänen, S., 2008. Kohti työelämälähtöisiä integroivia palveluja Työvoimatoimistojen ja työvoiman palvelukeskusten arviointitutkimus. Arbets- och näringsministeriets publikationer, Arbete och företagsamhet 18/2008. https://www.tem.fi/ajankohtaista/julkaisut/tyo_ja_yrittajyys/vuosi_2008?C=97984\&xmid=4002 ${ }^{105}$ Christensen, T. \& Lægreid, P. (2010), Reforming Norway's welfare administration. Statskontoret, 2010. http://www.statskontoret.se/globalassets/publikationer/om-offentlig-sektor-1-11/om-offentlig-sektor-3.pdf, s. 26. ${ }^{106}$ Alm Andreassen, T. \& Aars, J. (2015), Den store reformen - Da NAV ble til, Oslo: Universitetsforlaget, 2015. S. 51. ${ }^{107}$ Christensen, T. \& Lægreid, P. (2010), Reforming Norway's welfare administration. Statskontoret, 2010. www.statskontoret.se/globalassets/publikationer/om-offentlig-sektor-1-11/om-offentlig-sektor-3.pdf ${ }^{108}$ Hansen, H-T, Lundberg, K. G. \& Syltevik, L. J,(2013) Nav - med brukeren i sentrum?, Oslo: Universitetsforlaget, 2013, S. 21-22.
} 
marknadspolitiska målsättningar ledde ett ökat fokus på arbetslinjen i NAV till att resultatmålen i större grad kom att knyta an till åtgärder. Ytterligare drag av NPM är att NAV även jobbat nära marknaden och har upphandlat en rad aktiviteter. Samtidigt som inslagen av vägledning och uppföljning av den enskilde har ökat har man även i högre grad än förut satsat på självbetjäningslösningar genom digitalisering, för att effektivisera de grundläggande tjänsterna.

\subsubsection{Sverige}

Då den borgerliga regeringen tillträdde i Sverige hösten 2006 påbörjades genast en grundlig reform av styrningen och organiseringen av arbetsmarknadspolitiken. Det dåvarande Arbetsmarknadsverket omfattade Arbetsmarknadsstyrelsen (Ams) och tjugo länsarbetsnämnder med sammanlagt cirka 325 lokala arbetsförmedlingskontor. Reformen innebar att AMS och de 20 länsmyndigheterna lades ner, och från och med 2008 ersattes av Arbetsförmedlingen, en ny sammanhållen myndighet. En grundläggande tanke bakom centraliseringen var att åstadkomma en enhetlig och likvärdig service för arbetslösa. Den myndighetsstruktur som tidigare rådde, med totalt 21 skilda myndigheter, bedömdes dessutom på grund av oklara ansvarsförhållanden och administrativa dubbelarbeten försvåra styrningen och minska verksamhetens effektivitet. Regeringen ansåg bl.a. att länen inte var lämpliga som indelningsgrund för arbetsmarknadspolitiken utan att en förutsättning för högre effektivitet var att den geografiska organisationen bättre skulle avspegla de reella arbetsmarknaderna, vilket förutspåddes öka arbetskraftens rörlighet. ${ }^{109}$ Förvaltningsanslagen minskades även rejält i samband med reformen; anslaget för 2008 var 10 procent lägre än 2006. ${ }^{110}$

Den dåvarande borgerliga regeringen införde också en styrmekanism för att öka andelen privata aktörer, där en viss summa av Arbetsförmedlingens budget avsattes för upphandling av så kallade kompletterande aktörer. Målsättningen var att ge de arbetslösa mer individuellt anpassade tjänster och kortad arbetslöshetstid. ${ }^{111} \mathrm{De}$ tjänster som kom att utföras av kompletterande aktörer var de så kallade garantierna (Jobb- och utvecklingsgarantin, och Jobbgarantin för unga), rehabiliteringstjänster, sysselsättningsplatser, etableringslotsar och jobbcoachning. Även tidigare kunde AMS visserligen använda sig av privata aktörer, men omfattningen var betydligt mer begränsad. ${ }^{112}$ Bildandet av myndigheten Arbetsförmedlingen bar sammantaget

\footnotetext{
${ }^{109}$ Regeringens proposition 2006/07:89 Ytterligare reformer inom arbetsmarknadspolitiken, m.m. s. 72-76.

${ }^{110}$ Skoog, P., En ny myndighet formas. Stockholm: Arbetsförmedlingen, 2008, s. 11.

http://www.arbetsformedlingen.se/download/18.59a3cc6a1218b235ea480002672/1401114621432/nymyndighet.pdf

${ }^{111}$ Regleringsbrev: A2007/6711/A

${ }^{112}$ Karlsson,J., Szulkin, R., Lindblom, C. \& Bygren, M. (2014). Nya aktörer inom arbetsmarknadspolitiken:
} 
många tydliga drag av New Public Management, inte minst i ambitionen att skapa avgränsbara, mätbara, jämförbara och styrbara enheter med ökad effektivitet. ${ }^{113}$

Myndigheten Arbetsförmedlingen har under årens lopp omorganiserats internt flera gånger och även den interna styrningen har varit föremål för utvecklingsarbete efter att utvärderingar påpekat brister. Bland annat har ekonomistyrningen inte varit integrerad med verksamhetsplaneringen. ${ }^{114}$ Styrningen har länge varit inriktad på att uppfylla mål för vissa åtgärder, vilket krävt omfattande återrapportering om vad som gjorts och antalet personer i olika åtgärder. Denna återrapportering kom i praktiken att bli en indirekt styrning av politiken, ända ner till de enskilda arbetsförmedlarna, och medförde ett svagt ansvarstagande bland personalen och brist på förtroende mellan olika delar av organisationen. ${ }^{115}$ Den rödgröna regeringen som tillträdde 2014 har luckrat upp detaljstyrningen med en utveckling gentemot resultatstyrning. Denna förändring omfattar inte enbart departementets styrning av myndigheten, utan samtidigt inleddes en omfattande reform av den interna styrningen, som en del av en genomgripande reform av myndigheten (den s.k. Förnyelseresan). Såväl myndigheten som helhet som den enskilda förmedlaren kommer således få större utrymme att utifrån professionell kompetens anpassa insatserna för den enskilda sökande och lokala förhållanden på arbetsmarknaden. ${ }^{116}$ Samtidigt pågår ett arbete med att förenkla det arbetsmarknadspolitiska regelverket, liksom regelverket kring enskilda insatser. ${ }^{117}$ År 2014 lanserades även en långsiktig satsning för att stärka Arbetsförmedlingens kontakter med arbetsgivare, med syftet att förbättra matchningen på arbetsmarknaden och att förkorta vakanstiderna. I praktiken tog sig detta i uttryck i att fler arbetsförmedlare som arbetar med arbetsgivarkontakter anställdes, kompetensutveckling av personalen med fokus på arbetsmarknadskunskap och branschfrågor, utveckling av den uppsökande verksamheten, och framtagandet av nya digitala tjänster. ${ }^{118}$

I takt med att Arbetsmarknadsdepartementet har släppt på den formella styrningen av Arbetsförmedlingen har dialogen ökat i betydelse, vilket i praktiken ter sig som ökad löpande kontakt mellan departementet och Arbetsförmedlingen i olika bila-

\footnotetext{
Hur väl lyckas de och till vilken kostnad? Institutet för Framtidsstudier. Forskningsrapport 2014/4. s. 8.

${ }^{113}$ Se bl.a. Fransson, M. (2008) Självbeskrivning och tjänstekognition. Om processkartläggning på Arbetsförmedlingen.

Karlstad University Studies 2008:23.

${ }^{114}$ Statskontoret, 2016, s. 45.

${ }^{115}$ Statskontoret 2016:5 Analys av Arbetsförmedlingens interna styrning och utvecklingsarbete.

www.statskontoret.se/publicerat/publikationer/2016/analys-av-arbetsformedlingens-interna-styrning-och-utvecklingsarbete/ ; Wadman, Mats, analysdirektör Arbetsförmedlingen. Intervju 2015-11-20.

${ }^{116}$ Wadman, Mats, analysdirektör Arbetsförmedlingen. Intervju 2015-11-20.

${ }^{117}$ Ds 2014:29 Förtydliganden och förenklingar inom det arbetsmarknadspolitiska regelverket; Regeringens skrivelse

2014/15:42 Riksrevisionens rapport om Arbetsförmedlingens arbete vid varsel m.m.

${ }^{118}$ Arbetsförmedlingen 2016, Arbetsförmedlingens arbetsgivarkontakter.
} 
terala arbetsgrupper. I dialogen med departementet får Arbetsförmedlingen även en större roll i utvecklingen av politiken och mer karaktär av en expertmyndighet, med större möjlighet till en evidensbaserad politik. ${ }^{119}$

Vid sidan av reformer i organisation och styrning har andra nämnvärda reformer skett under det senaste decenniet som påverkat Arbetsförmedlingen starkt. I samband med att den borgerliga regeringen kom till makten, kom arbetsmarknadspolitiken också att starkt karakteriseras av en "arbetslinje". Framförallt genom ändringar i arbetslöshetsförsäkringen, men också genom insatser för att stödja jobbsökande, eftersträvades ökade incitament för de arbetslösa att aktivt söka arbete. En reform av sjukförsäkringen år 2008 och den så kallade etableringsreformen 2010, då Arbetsförmedlingen gavs det samordnande ansvaret för nyanlända från kommunerna, har även påverkat myndigheten starkt. Inflödet av nyanlända och personer från sjukförsäkringen - två grupper som traditionellt stått längre ifrån arbetsmarknaden - har medfört att förmedlingen fått ändra sitt arbetssätt. Arbetsförmedlingens ökade fokus på grupper som står längre ifrån arbetsmarknaden bottnar således framförallt i politiska reformer för att stimulera en ökning av arbetskraftsdeltagandet bland dessa grupper, snarare än en omprioritering inom arbetsmarknadspolitiken i sig. Under 2016 har en ytterligare förändring av regelverket gjorts, som arbetsmarknadsdepartementet anser bör leda till att inflödet till Arbetsförmedlingen från personer som står långt ifrån arbetsmarknaden minskar. Det återstår att se vilka effekter det får för Arbetsförmedlingens arbete.

\subsection{Reformer i de autonoma regionerna}

\subsubsection{Färöarna}

Lagen om arbetslöshetsförsäkring och arbetsförmedlingen (ALS)

Den viktigaste reformen på den färöiska arbetsmarknaden är införandet av lagen om arbetslöshetsförsäkring och arbetsförmedling (ALS loven) år 1992, det är också den enda lagen som finns på arbetsmarknadsområdet. Det har löpande varit nya tillägg och lagändringar av lagen. Lagen har inneburit att färöingarna för första gången fick en allmän arbetslöshetsförsäkring - ALS-ordningen. Systemet infördes som en följd av en förhandling mellan arbetsmarknadens parter, eftersom en arbetslöshetsförsäkring verkligen behövdes. Den färöiska regering tillsatte en kommission som skulle lägga fram förslag och rekommendationer till beslutsfattarna om utformningen av arbets-

\footnotetext{
${ }^{119}$ Intervjuer med Mikael Sjöberg, Clas Olsson, Mats Wadman, Mia Löw och Jonas Jarefors.
} 
löshetsförsäkringen. Kommissionen slutförde sitt arbete år 1991 och gav två övergripande rekommendationer kring försäkringen: 1) Ett system där både arbetsgivare och arbetstagare har fullt ansvar i förhållande till förvaltningen och finansieringen av systemet. I händelse av att ALS saknar medel, ligger ansvaret hos båda parter. Skälet till detta är att ett sådant system skulle vara bäst för både parterna och samhället. 2) ALS bör också fungera som en arbetsförmedling med jobbskapande program. Dessutom rekommenderade kommissionen att medlemskap i ALS borde vara frivillig (som det är i de flesta nordiska länder), men regeringen höll inte med om den sista rekommendationen och därför står det nu i lagen att alla arbetstagare och arbetsgivare ska finansiera och vara medlemmar i arbetslöshetskassan. Anledningen till detta var att undvika att bara de mest utsatta, t.ex. deltid- och flexarbetare, skulle betala in till arbetslöshetskassan och på så sätt riskera kassans hållbarhet.

Ökad fokus på aktivering - från passiv till aktiv arbetsmarknadspolitik

Enligt en intervju med Sørin P. Sørensen, avdelningschef på ministeriet för arbetsmarknad och transport, har den senaste ändringen i lagen om ALS (den 1 januari 2013) inneburit en övergång från en passiv förvaltning och utbetalning av medel till en mer aktiv. Tidigare fokuserade ALS också på att hjälpa arbetslösa genom krav på att delta $\mathrm{i}$ sysselsättningsskapande program, men ändringen 2013 har inneburit att det nu finns rättslig grund för ALS att kunna ställa fler krav på att arbetslösa deltar i aktiviteter. Kraven har alltid varit en del av lagen, men med ändringen måste arbetslösa nu delta $\mathrm{i}$ aktiveringen. Om en arbetslös inte deltar i aktiviteterna, kan denne i första hand bli av med sin ersättning i ett antal veckor och i slutändan riskera att helt förlorar arbetslöshetsersättning.

Lika så belyser Henri Petersen, ansvarig för Socialstyrelsen i intervju att ändringen under 2013 har inneburit att även Socialstyrelsen är mer inriktad på aktivering av arbetslösa. "Reformen omfattar både förändringar i de grundläggande delarna och nya instrument $i$ arbetet med att säkra framtiden för den färöiska arbetskraften. Det viktigaste inslaget i reformen är en ny lag, som översatt till svenska kan kallas "Lagen om initiativfrämjande insatser." I lagen föreskrivs bestämmelser kring rehabilitering och aktivering, men har även bestämmelser kring sjukpenning och socialbidrag. I reformen presenterades grundläggande förändringar i systemet för socialbidrag. Kontantförmåner som idag är behovsprövade, kommer att ändras till fast ränta, vilket innebär en omvälvning för både medborgare och staten. Detta grundar sig i att den behovsprövande delen är en "förvaltningsmässig resurstung del". För medborgaren innebär förändringen att denne måste anpassa sig efter särskilda fasta riktlinjer, i jämförelse till det nuvarande systemet, där tjänsten anpassas efter individens situation. Enligt uppgifter från Socialstyrelsen har det behovsprövandefunktionen sina styrkor och fördelar, men det finns också många 
nackdelar (t.ex. resurskrävande, bristande transparens, risk för mytbildningar och brist på möjligheter att arbeta med incitament etc.). Henri Petersen förväntar sig att övergången till det nya systemet ger möjligheter att till exempel bädda in olika ekonomiskt incitament med att gå från en så kallad passiv tillvaro till mer aktivt deltagande, där aktivt deltagande premieras i form av förmåner. Det har tidigare funnits regler om aktivering, men dessa har inte använts under många år, och aktivering är i stort sett ett okänt fenomen på Färöarna. Det införs även, för första gången, uppföljningen av sjukersättningsfall. Som det är i dag är det enbart läkarintyg och en medicinsk diagnos som avgör om du har rätt till sjuklön, och det finns nästan ingen form av uppföljning.

"Jeg har store forventninger til, at arbejdsmarkedsreformen med tiden vil få stor betydning for den økonomiske udvikling og for det færøske velfærdssamfund". (Henri Peterson, Socialforvaltningen)

\section{Bättre villkor för arbetslösersättning i ALS-ordningen}

En annan lagändring som är av stor betydelse har lyfts fram av VD:n för ALS. Under 2009 genomfördes en relativt stor förändring i lagen. Taket för ersättningen höjdes med 7000 DKK per månad, och beräknades utifrån 80 procent av din lön, vilket är mer än tidigare. Anledningen till detta var att det annars fanns en risk för att medborgarna skulle flytta utomlands - och särskilt Danmark - eftersom det annars skulle vara mer fördelaktigt att vara arbetslösa i Danmark än på Färöarna. Det har alltid varit en utmaning på Färöarna att behålla en stor och kvalificerad arbetskraft. Därför använde de lagreformen i ALS-ordningen för att skapa bättre villkor för att stanna på Färöarna. Detta kunde delvis även genomföras då ALS-fondens ekonomi var mycket god. Det har inte gjorts utvärderingar av effekten av denna lagändring, men i det Ekonomiska rådet har det presenterats att ändringen har haft en stabiliserande faktor för att upprätthålla en stor arbetskraft.

Som beskrivits ovan har alla intervjuade nämnt att under de senaste 10-15 åren har det blivit ett ökat fokus på att flytta människor från passivt stöd för aktivering. Generellt bör det noteras att det inte har skett några grundläggande förändringar i den färöiska arbetsmarknadspolitiken sedan 1992, när ALS-lag antogs i parlamentet. Utvecklingen kan i stora drag beskrivas att man har övergått till att använda aktivering som ett medel till att minska arbetslösheten och få arbetskraften mer rörlig. ALS har tidigare ställt krav på aktivering, men det är först med ändringen år 2013, som det har inneburit större krav på arbetslösa att delta i aktivering för att få ekonomiskt stöd. 


\subsubsection{Grönland}

I Grönland har den viktigaste reformen på senare tid implementerats under 2016. Det är en sammanslagning av de kommunala arbetsmarknadskontoren och Majoriaq (se kapitel 5.2). Med lagändringen skapas det en gemensam ingång till både vägledning, vidareutbildning och utformning av individuella handlingsplaner till arbetslösa. Syftet med reformen är att skapa en enklare administration och starkare grund för kompetensutveckling bland personalen till gagn för de arbetssökande.

Det finns idag 18 olika Majoriaq och kontor för medborgarservice på Grönland, som delvis styrs av samma lagar. Därutöver har de fyra kommunerna organiserat sig på olika sätt, dels olika i olika kommuner, dels olika inom varje kommun. Den nya reformen är tänkt att underlätta att samlas kring gemensamma administrativa lösningar, vidareutbildning av personal och att göra landstäckande insatser utan en hög grad av stöd till varje kommunal enhet.

Ser man på reformer av tjänsteutbudet kan det sammanfattas med insatser för att öka motivationen för mottagaren av antingen offentligt bidrag eller en aktiv arbetsmarknadsåtgärd att ta ett arbete eller påbörja en utbildning. Det har generellt sett varit fokus på att öka incitamentet att delta i vidareutbildning eller arbetsmarknadsutbildning av olika slag under perioder av arbetslöshet. Det gäller både lagändringen om hjälp från det offentliga (Landstingsforordning nr. 15 af 20. november 2006 om offentlig hjælp) samt lagändring av landstingsförordningen om arbetsmarknadsåtgärder (Inatsisartutlov nr. 2 af 15. maj 2014 om arbejdsmarkedsydelse). Därutöver är det genomfört en lagändring av förtidspensions-, revaliderings- och flexjobbsområdet under 2015 (Inatsisartutlov nr. 40 af 9. december 2015 om førtidspension), som tydliggör den politiska ambitionen om att stärka de arbetslösas arbetsförmåga. En huvudpunkt i lagändringen är att bedömningsprocessen som den arbetslösa ska gå igenom för att värdera arbetsförmågan ska göras av ett team från kommunen där kompetens inom utbildning, arbetsmarknadsutbildning, sysselsättning men också hälsa och psykologi ska ingå.

Revalidering, det vill säga rehabilitering med fokus på kompetens, kunskaper och arbetsförmåga, har generellt sett blivit ett centralt instrument för att utveckla arbetsförmågan. Som ett led i reformen av förtidspension och de målsättningar för arbetsmarknaden som följer av reformen ska arbetet med revalidering prioriteras upp och stärkas. ${ }^{120}$

Departementet för Näringsliv, Arbetsmarknad \& Handel har därför satt igång ett intensivt arbete med att påbörja en informationskampanj för att sprida kunskap om

\footnotetext{
${ }^{120}$ Se noter till lagförslaget: Naalakkersuisut, 2015, Almindelige bemærkninger til lovforslaget om førtidspension, 30. januar 2015 , FM 2015/98.
} 
möjligheten till revalidering. Departementet har vidare de senaste åren haft flera kurser för kommunernas arbetsmarknadskontor för att öka antalet deltagare i revalidering. Dock visade en arbetsmarknadsrapport från 2014 att antalet faktiskt sjunkit mellan 2012 och 2014. Det avspeglar i hög grad utmaningarna för många kommuner med att implementera arbetsmarknadsåtgärder generellt, på grund av demografiska utmaningar och brist på kompetens i att utföra en revalidering. Det har inte gjorts en specifik utvärdering av reformen, men noterna till lagförslaget den 30 januari 2015 räknar med att reformen ska bidra med ytterligare 64 personer i arbete samt 22 miljoner i förbättring av de offentliga finanserna. ${ }^{121}$

Det är vidare tydligt att den grönländska arbetsmarknaden har genomgått en omfattande förändring över de senaste 10 åren. Särskilt fiskeindustrin har upplevt stora förändringar som har haft stor betydelse för arbetslösheten, som steg markant mellan åren 2009 och 2012. Det har medfört ett stigande behov för att sätta in arbetsmarknadsåtgärder. Tidigare var arbetsmarknadspolitik ett mycket lågprioriterat område enligt de respondenter som intervjuats i de berörda myndigheterna och självstyret. Den generella åsikten var att arbetslöshet enbart kunde skyllas på individen, att det var självförvållat. Därför var det också mycket begränsat vilka insatser som fanns för att bekämpa arbetslöshet. Men som en konsekvens av den stora arbetslöshet som tillkommit efter näringslivets omstrukturering har det blivit en större förståelse för de strukturella orsakerna till arbetslöshet och därmed också olika insatser för att bekämpa den.

Under de senaste tio åren har den mest markanta förändringen utan tvekan varit skiftet i riktning mot att bekämpa arbetslösheten genom att säkra att de arbetssökandes kompetens matchar näringslivets behov. Det har i synnerhet skett ett skifte i användandet av arbetsmarknadsutbildning och revalidering på olika sätt.

Det baseras på att 90 procent av de arbetslösa, vilket motsvarar 56 procent av arbetskraften, saknar högre utbildning. Detta skifte i ambitioner kan ses genom att Piareersarfik grundades 2008, men också genom de insatser som gjorts för att bekämpa arbetslösheten under de senaste åren. Insatserna har bestått av en rad olika instrument mot olika grupper, i synnerhet dem utan utbildning:

- Extra arbetsmarknadsutbildning (PKU) för uppkvalificering av arbetslösa.

- Vägledningskurser för arbetslösa.

- Ytterligare akademisk vidareutbildning (AEU).

\footnotetext{
${ }^{121}$ Ibid.
} 
- MajoriaqMedel till sysselsättningsinsatser för arbetslösa i mindre orter och på landsbygden.

- Majoriaq verkstads- och jobbträning för unga arbetslösa.

- Ett ökat fokus på revalidering.

Samtidigt har det betytt att departementet för arbetsmarknad är mycket aktiva för att följa upp insatserna. I 2015 lanserades till exempel en offenltig jobbportal som ska bemöta utmaningarna med Grönlands geografi som kan göra det svårt att få en överblick över var det finns lediga jobb samt om det finns arbetskraft som kan anställas. Denna utmaning har tidigare ibland lett till att arbetsgivare primärt rekryterat utomlands, men ambitionen är nu att öka rekryteringen inom Grönland.

\subsection{3 Åland}

Till skillnad från övriga länder och autonoma regioner har det inte varit några betydande reformer inom arbetsmarknadspolitiken på Åland de senaste tio åren. Den senaste större reformen som genomförts är då Ams blev en egen myndighet år 2006 och en helt ny lagstiftning om arbetsmarknadspolitisk verksamhet trädde i kraft. Innan dess var arbetsmarknadsförvaltningen en fristående byrå vid landskapsregeringen (Ålands arbetsförmedlingsbyrå). Den huvudsakliga orsaken till reformen (enligt intervjurespondenterna) var troligen att Landskapsregeringen skulle syssla mer med politik, ej själva servicen och verkställigheten av politiken gentemot kunden. Utvecklingen på Åland är generellt att den typen av service som ges till enskilda har placerats i separata myndigheter. Det är ett sätt att skilja politiska beslut från ärenden som gäller enskilda.

Ams, och innan dess arbetsförmedlingsbyrån, service har alltid varit koncentrerat till Mariehamn. Det fanns inga lokala verksamhetsställen heller innan reformen och inga förändringar i styrningen har gjorts sedan bildandet av Ams, det är samma lagar och regelverk som gäller. Det har inte gjorts några studier om hur denna reform påverkat utfallet, eller någon annan typ av utvärdering.

Antalet nyinflyttade har ökat vilket påverkat Ams kundsegment. Ams har också avsatt en personalresurs för flyktingar. Denna inriktning är alltså mer resultatet av en förändring i kundunderlaget än av en ny politisk inriktning.

Undan för undan utvecklar Ams nya tjänster så att kunderna ska kunna utföra sina ärenden elektroniskt. Det finns på agendan att öka andelen tjänster som kan utföras elektroniskt, men detta ses helt enkelt som ett komplement till den personliga servicen, för att underlätta för kunder och ta bort manuella administrativa moment. Inga ambitioner finns om att ersätta personal med elektroniska resurser. Ams har heller 
inte varit under de sparkrav som präglat arbetsförvaltningen i Finland (och som delvis har drivit digitaliseringen där).

\subsection{Likheter och olikheter i genomförda reformer}

Bland motiven till de reformer som under de senaste tio åren genomförts i de nordiska ländernas administrativa styrning och organisering av arbetsmarknadssystemen hitttas många likheter. Ett fokus på aktiveringspolitik, eller "arbetslinjen", har i samtliga länder lyfts som en grundläggande förutsättning för att utöka arbetskraftsdeltagandet och därmed bibehålla eller utveckla välfärden. OECD definierar aktiveringspolitik som en politik med syfte att få in fler människor i den effektiva arbetskraften, att motverka negativa effekter av arbetslöshetsersättning och andra passiva ersättningar genom att införa villkor om aktivt arbetssökande och deltagande i sysselsättningsfrämjande åtgärder, samt att styra arbetsförmedling och andra arbetsmarknadsåtgärder så att de effektivt främjar och stödjer en återgång till arbetet. ${ }^{122}$ I konkreta reformer syns denna utveckling tydligast i Danmark, Färöarna, Norge och Sverige. I dessa länder har aktiveringslinjen tydligt tagit sig uttryck i förändringar i den rättsliga regleringen av arbetslöshetsersättningen och annan ekonomisk ersättning, med fokus på att förbättra incitament för att förstärka individers deltagande på arbetsmarknaden. Även i Finland samt på Grönland och Island har ersättningssystemen justerats för att öka incitament till aktivering, men på ett betydligt mindre påtagligt sätt.

Som ovan konstaterats har en utökning av arbetskraftsdeltagandet legat högt på den politiska agendan i flera nordiska länder. Parallellt med förändringar i pensionssystemen för att förlänga tiden i arbetslivet, har flera länder i sin arbetsmarknadspolitik i högre grad kommit att fokusera på individer som står längre ifrån arbetsmarknaden. Flera länder har även satsat på att minska sjukfrånvaron, och satt ett ökat fokus på rehabilitering/revalidering. Även här syns olika tillvägagångssätt, där exempelvis Danmark och, Sverige ökat krav på aktivering av långtidssjukskrivna personer medan Finland snarare har fokuserat på utveckling av servicen inriktad på målgrupper med övriga problem utöver arbetslöshet, i och med att arbetsmarknadsservice kopplats samman med socialservice. I Norge har både aktivering och sammankoppling av olika servicetyper varit i fokus.

I Norge kom NAV-reformen att leda till att brukargruppen blev mer resurssvag än vad som varit fallet för den tidigare Aetat. Samma utveckling skedde i Sverige, då inflö-

\footnotetext{
${ }^{122}$ Martin, J. P. (2014) Activation and Active Labour Market Policies in OECD Countries: Stylized Facts and Evidence on their Effectiveness. IZA Policy Paper No. 84, s. 3.
} 
det till Arbetsförmedlingen förändrades till följd av förändringar i sjukförsäkringen och övertagandet av etableringsansvaret av nyanlända. Även om dessa reformer i praktiken medfört ett större fokus på personer som stod längre ifrån arbetsmarknaden har det inte handlat om en politisk omprioritering i arbetsmarknadspolitiken i sig, då personer som står långt ifrån arbetsmarknaden redan tidigare var en prioriterad målgrupp i Arbetsförmedlingens uppdrag. På Island och i Danmark har ingen större förändring i målgruppsorientering skett. I Danmark har kärnmålgrupperna för arbetsmarknadspolitiken varit mer eller mindre konstant, med fokus på framförallt unga och långtidsarbetslösa.

Ett annat återkommande motiv till organisatoriska reformer i flera av länderna har varit problem kring ansvarsfördelning, där olika aktörer sett den enskilde som någon annans ansvar. Inte minst förefaller sådana problem vara vanligt förekommande mellan kommun och stat, där kommunerna enligt nordisk modell traditionellt ofta står för samhällets yttersta skyddsnät med ansvar för socialbidragstagare, medan staten stått för arbetsmarknadspolitiken. Arbetsmarknadspolitiska analyser visar att de redskap offentliga arbetsförmedlingar har att tillgå inte alltid är tillräckliga för att möta behoven framförallt hos personer som står långt ifrån arbetsmarknaden till följd av underliggande problem av olika natur. I dessa fall kan lokala partnerskap vara avgörande. ${ }^{123}$ Som en lösning på denna problematik har såväl Finland som Norge utvecklat system med s.k. one-stop-shops där flera myndigheters service slagits samman på lokal nivå och kommunernas aktiviteter för personer utanför arbetsmarknaden därmed i större eller mindre utsträckning integrerats med arbetsmarknadspolitiken. I Danmark har den tidigare splittrade ansvarsfördelningen åtgärdats genom att kommunerna fått ta över helhetsansvaret för de aktiva arbetsmarknadsinsatserna och därmed tydligare inkluderat socialbidragstagare i arbetsmarknadspolitiken. Island och Sverige skiljer sig här från de andra nordiska länderna i och med att det inte har skett några konkreta förändringar i ansvarsfördelningen mellan stat och kommun, även om frågan om kommunernas "parallella system" med egna arbetsmarknadsåtgärder och oklarheter i ansvarsfördelningen mellan Arbetsförmedlingen och kommunerna länge varit föremål för diskussion $i$ Sverige.

Även kring styrningen mellan stat och kommun finns inslag av incitamentsbaserad politik, där kommunerna antingen genom passiva eller aktiva "styrinstrument" eller åtgärder på olika sätt i högre grad aktiverats inom arbetsmarknadspolitiken. I praktiken tar sig detta uttryck i en utveckling där kommunerna i högre grad driver egna aktiva arbetsmarknadsinsatser, parallellt med den statliga arbetsmarknadspolitiken (ex. Finland och Sverige), men även i att kommunerna fått en större roll inom den statliga

\footnotetext{
${ }^{123}$ Weishaupt J. Timo (2014) Central Steering and Local Autonomy in Public Employment Services Analytical paper October 2014 PES to PES Dialogue The European Commission Mutual Learning Programme for Public Employment Services, s. 23.
} 
arbetsmarknadspolitiken (ex. Danmark, Finland och Norge). Som ovan visas har detta i Danmark tagit sig utryck i direkta ekonomiska incitament inbyggda i den kontinuerliga styrningen av de kommunala jobbcentren, medan de finska och svenska kommunerna fått en större roll i finansieringen av de långtidsarbetslösa. Skillnaden är dock att denna utveckling i Sverige varit en indirekt följd av förändringar i arbetslösförsäkringen, vilket lett till att fler arbetslösa blivit beroende av försörjningsstöd, medan det i Finland varit en direkt överföring av finansieringsansvaret. OECD har betonat vikten av en koppling mellan finansieringen av ersättningar och implementeringen av arbetskraftsservice, genom någon form av incitamentsstyrning. ${ }^{124}$

I flera av länderna har de reformer som under det senaste decenniet implementerats inom styrning och organisation tydliga drag av New Public Management. Detta tar sig bland annat uttryck i en marknadsanpassning, där flera länder strävat efter mer individanpassade åtgärder, en ökad involvering av privata eller andra upphandlade kompletterande aktörer och digitalisering. Det bör påpekas att fördelar med att involvera privata aktörer i den offentliga arbetskraftsservicen framhålls i flera studier, men ofta med reservationer. Bland fördelarna nämns privata aktörers potential att bidra med innovativa åtgärder, samt att konkurrens kan bidra till förbättring och effektivisering av verksamheten. ${ }^{125}$

I samtliga länder har digitaliseringen i någon mån utvecklat servicen. Dels genom datorsystem som strävat till att effektivisera den interna administration och styrningen och underlätta handläggarnas arbete, dels i form av nya tjänstekanaler för arbetssökande. Framförallt i Finland, Norge och Sverige har man eftersträvat mer självbetjäningsfunktioner med hjälp av digitala verktyg. Även i Danmark har man haft fokus på att implementera digitaliseringsfunktioner i sysselsättningsåtgärder.

I sin strävan efter mer eller mindre samma mål har de nordiska länderna alltså sökt olika lösningar i förnyandet av såväl arbetsmarknadspolitikens innehåll som organisation. Trots ovan identifierade likheter i viljan att utöka och mobilisera arbetskraften, och trots att gemensamma drag kan skönjas bland reformerna i styrning och organisering, har olikheterna i de nordiska ländernas arbetsmarknadspolitiska servicestrukturer i praktiken kommit att öka på senare tid. ${ }^{126}$ Island och Sverige har alltjämt en mer traditionell organi-

\footnotetext{
${ }^{124}$ OECD (2015), Employment Outlook, s. 214.

${ }^{125}$ Se bl.a. Finn, Dan (2011) Subcontracting in Public Employment Services: Review of research findings and literature on recent trends and business models, The European Commission Mutual Learning Programme for Public Employment Services, GHK Limited / Budapest Institute, DG Employment, Social Affairs and Inclusion, Brussels., s. 4 och HoPES - Working Group. PES Efficiency Working Group, Final report, October 2013, s. 13.

${ }^{126}$ Arnkil, R., Karjalainen, V., Saikku,P., Spangar, T., Pitkänen, S., 2008. Kohti työelämälähtöisiä integroivia palveluja Työvoimatoimistojen ja työvoiman palvelukeskusten arviointitutkimus. Arbets- och näringsministeriets publikationer, Arbete och företagsamhet 18/2008. https://www.tem.fi/ajankohtaista/julkaisut/tyo_ja_yrittajyys/vuosi_2008?C=97984\&xmid=4002, s. 328. Se
} 
sering av servicestrukturen med en statlig Arbetsförmedling, medan övriga länder, som ovan påvisats, i varierande grad involverat och/eller integrerat kommunerna i den tidigare statliga arbetsmarknads-verksamheten. Även avvägningar i balansen mellan individanpassning och likvärdighet i servicen till arbetssökande har tett sig olika i olika länder, där Finland och Sverige betonat en mer central top-down-styrning av arbetsmarknadspolitiken, medan Norge och Danmark i högre grad förefaller ha betonat anpassning till lokala och individuella förutsättningar med mer bottom-up-inriktade inslag i styrningen. ${ }^{127}$ Trots att Sverige fortsatt har en centraliserad organisation har landet genom en tydlig skiftning från detaljstyrning till resultatstyrning rört sig mot en styrmodell som tillåter mer lokal anpassning och ger de lokala kontoren och enskilda arbetsförmedlare större frihet. Flera studier pekar på vikten av en välfungerande styrning för att kunna säkerställa en lämplig balans mellan central vägledning och lokal autonomi, något som krävs för att kunna säkerställa en likvärdighet i servicen och samtidigt möjliggöra den individanpassning som krävs för en effektiv arbetsmarknadspolitik. ${ }^{128}$ Just effektivitet har även kommit i fokus i många länder, där det generellt går att se en trend gentemot strävan efter en mer evidensbaserad politik. Hur detta i praktiken implementerats skiljer sig dock åt mellan länderna.

I tabell 3 nedan sammanställs de reformer som gjorts, de huvudsakliga motiveringarna till reformer, fokus i reformerna, samt vilka aspekter som har berörts. I kapitel 8 studeras de utvärderingar och analyser som finns kring effekter av de reformer som gjorts av styrningen.

även Oosi (2012): Työvoimapolitiikan suunnittelu-, ohjaus- ja organisaatiomallin arviointi. Työpoliittinen aikakauskirja 2/2012. s. 76.

${ }^{127}$ Se även Työpolitiikan palvelurakennearviointi: Työpolitiikan palvelurakenteen ohjaus ja kolmikantaytetyö. Valmisteluryhmän raportti. TEM 28.10.2014. s. 17-18.

${ }^{128}$ Weishaupt J. Timo (2014) Central Steering and Local Autonomy in Public Employment Services Analytical paper October 2014 PES to PES Dialogue The European Commission Mutual Learning Programme for Public Employment Services, s. $24-25$. 
Tabell 3: Översikt över genomförda reformer inom organisering och styrning 2005-2015 (exklusive de autonoma regionerna)

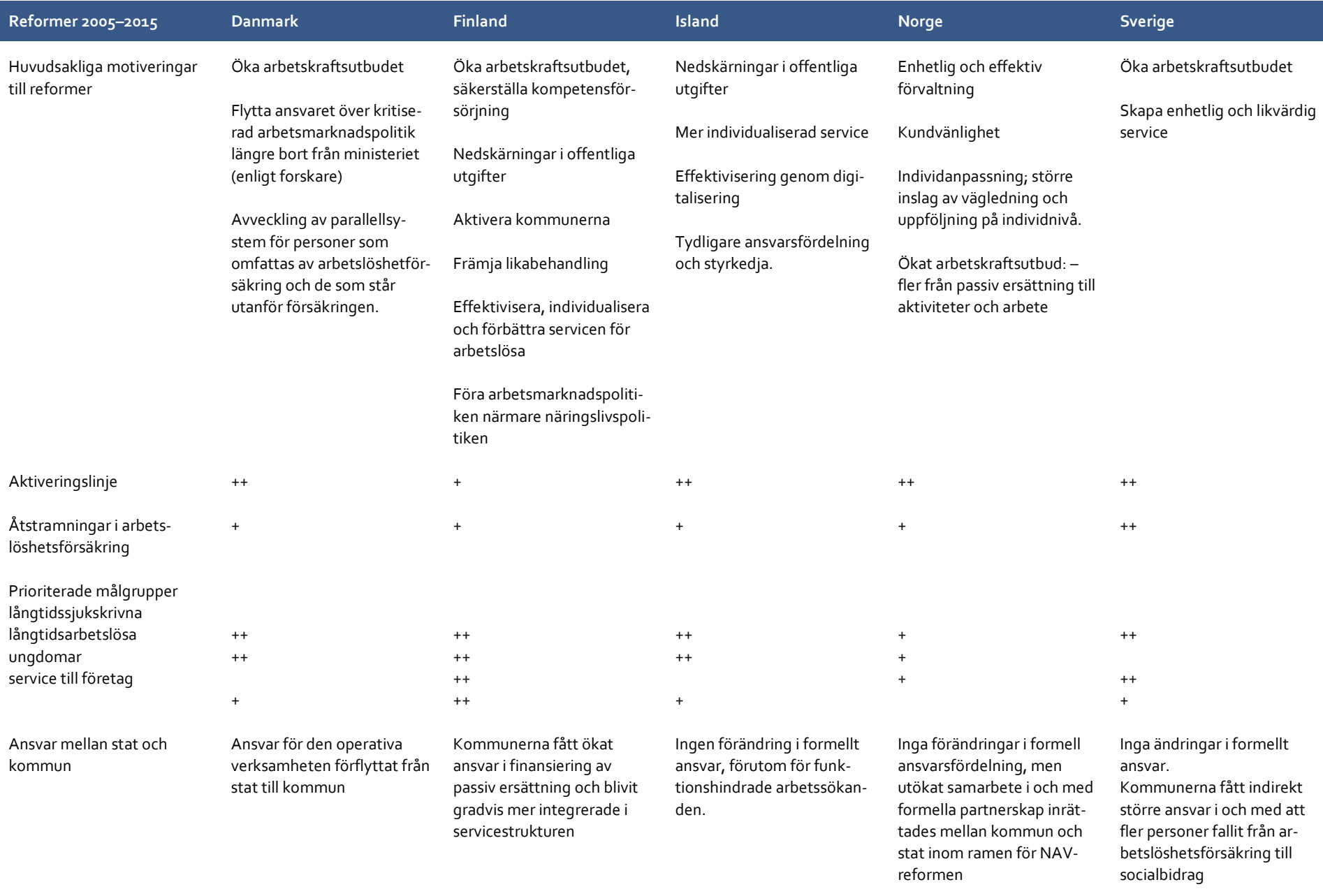


Involvering av privata aktörer

Okad upphandling av privat ktörer i början på 2000-

Okad upphandling av privata vändning av privata aktör vändning av privata

Digitalisering av service

Styrinstrument (detalj-I målstyrning)

Detaljerad kvantitativ målstyrning infördes i början på 2000-talet, nu utveckling mot evidensbaserad resultatstyrning med inbyggda citament för att snabbt arbetssökande i jobb.

Sammanslagning av olika serviceformer

Ja, sammanslagning av ervice (aktiva arbetsmarknadsåtgärder) för arbetssökande med socialbidrag och arbets-sökande med arbetslöshetsersättning lösa och ungdomar. phandling av privata aktörer under 2000-talet. arbetsformedlingar under retag

Lång tradition av kvantifierad resultatstyrning. Hög grad av detaljerad informatonsstyrning från central

Delvis: sektorsövergripande samservicekontor (kommun socialförsäkringsmyn chärörmedling fö

målgruppen långtidsarbetskrisen 2009-2013

ad upphandling av tjanser i samband med NAV -

er har fatt större roll genom upphand reformen, men nu utveckling mot mindre upphand-

ng av arbetsmarknads-

tjänster. Ökad upphandling av privata aktörer i början på 200o-talet, men "krav" pa anvandning av privata aktorer minskats med tiden.

$+(+)$

Mer fokus på evidensbaserad politik.

Åtgärdsbaserad målstyrning infördes i samband med NAV-reformen. Nu diskuteras introducering av resultatstyrning.

Detaljerad kvantitativ målstyrning infördes 2008, nu Poํํำ págående utveckling mot tyrning.

Ja Island har haft samar-

betsprojekte med t.ex.

Ja, sammanslagning av

kommunal socialtjänst,

kommuner riktade till ung

socialförsäkringsmyndighet

och arbetsför-medling. 


\section{Uppföljning och effekter av genomförda reformer}

Som ovan konstaterats finns det många likheter i de bakomliggande motiven till och målsättningar med de reformer $\mathrm{i}$ arbetsmarknadspolitikens organisation och styrning som under 2000-talet genomförts i de nordiska länderna. Strategier bakom reformer och val av åtgärder skiljer sig dock åt. Därför är det särskilt intressant att granska vilka effekter som uppnåtts med de genomförda reformerna i respektive land. Nedan redogörs för de nationella reformernas måluppfyllelse och deras effekt på matchning och sysselsättning eller aktivering av de målgrupper som stått i fokus, med utgångspunkt i nationella utvärderingar, uppföljningar och analyser i den mån sådana funnits tillgängliga. Till viss del beskrivs reformernas utfall även på basen av de intervjuer som genomförts på såväl central som lokal nivå.

Inledningsvis bör det dock påpekas att de utvärderingar som ligger till grund för nedanstående analys av effekterna i varje land varierar i omfång och fokus och det finns således få möjligheter till jämförbarhet mellan utvärderingarna i de olika länderna. Vidare finns det naturligtvis otaliga faktorer som påverkar utfallet av dylika arbetsmarknadsreformer och hur de svarar mot de aktuella behoven på arbetsmarknaden, varför kausaliteten mellan reform och utfall, eller mellan organisationsskillnader och utfall i de olika länderna, är näst intill omöjlig att fastställa. De forskare vi har intervjuat i samtliga länder anser att samhället idag vet väldigt lite om effekter inom arbetsmarknadspolitiken.

De reformer som har gjorts i de autonoma regionerna beskrivs samlat i avsnitt 7.2 ovan. De har i regel inte utvärderats och är därför svårare att diskutera i samband med detta avsnitt. De effekter som har kunnat ses behandlades istället direkt i avsnitt 7.2, men de ligger även till grund för den avslutande diskussionen i kapitel 9 nedan.

\subsection{Danmark}

Generellt sett finns det få utvärderingar och analyser gällande de reformer som genomförts i organisation och styrning i Danmark. Den danska arbetsmarknadspolitiken har haft ett kraftig fokus på aktivering, och det finns därmed gott om utvärderingar om effekten på olika aktiva åtgärder och förändringar i ersättningssystemen. Som 
ovan beskrivits baserades den senaste reformen, Beskæftigelsesreformen år 2014, på en gedigen utredning som tillhandahöll evidens om effektivitet för de åtgärder som implementerades i och med reformen.

Danmark har med de gradvisa reformer som genomförts under de senaste 15 åren lyckats harmonisera social- och sysselsättningspolitiken på så vis att arbetssökande med socialbidrag och arbetssökande som omfattas av arbetslöshetsersättning omfattas av samma rättigheter och skyldigheter vad gäller aktiva insatser. Strukturreformens fokus på enhetlighet hade som utgångspunkten att i stort sett samma typ av åtgärder som visat sig effektiva på personer som stod nära arbetsmarknaden skulle få samtliga kategorier av arbetssökande i arbete. Utvärderingar visade dock att så inte var fallet. Efter att den evidensbaserade politiken inledningsvis haft ett fokus på vad som fungerar för personer som står närmare arbetsmarknaden har man nu i högre grad kommit att ägna uppmärksamhet åt de grupper som står längre ifrån arbetsmarknaden, som personer som levt länge på socialbidrag, invandrare och unga med olika typer av problematik, och som i första hand kan behöva hjälp med att komma närmare arbetsmarknaden snarare än att direkt integreras i arbetslivet.

Det finns begränsat med evidens kring resultaten av den typ av incitament som är inbyggda i det statliga ersättningssystemet för kommunernas insatser på arbetsmarknadsområdet. År 2006 blev den statliga ersättningen för socialbidrag avhängig om den arbetssökande var i en aktiv åtgärd eller inte. En utvärdering av denna förändring visar att aktiveringsgraden steg med 8 procent till följd av denna reform. Resultaten tyder vidare på att den ökade aktiveringsgraden å ena sidan har en viss inlåsningseffekt, och å andra sidan lett till sämre tillgång till socialbidrag på ett sätt som gör att det totala antalet socialbidragstagare ändå blev opåverkat av reformen.

I samband med den organisatoriska reformen i Danmark då jobcenter inrättades, infördes som ovan beskrivits även nya rigida styr- och uppföljningsmekanismer för att på ministerienivå systematiskt kunna fånga in data om effekten av de olika aktiva insatserna. Detta ledde till kritik om att arbetsmarknadspolitiken i för stor utsträckning kom att handla om "produktion", snarare än den enskilde kundens behov. Denna kritik resulterade i de nyligen genomförda reformerna mot en styrning som i högre grad fokuserar på att stärka kommunernas incitament till att erbjuda åtgärder som faktiskt leder till sysselsättning. Inga utvärderingar finns ännu tillgängliga, men flera intervjurespondenter framhåller risken med att den incitamentbaserade styrningen, där statens ersättning till kommunerna successivt trappas ned, leder till en snedvridning $i$ prioriteringen av målgrupper. Av rent ekonomiska skäl kan kommunerna komma att prioritera en "mellangrupp" framför dem som står närmast eller längst ifrån arbetsmarknaden, eftersom de som står närmast arbetsmarknaden förväntas klara sig 
själva, och de som står längst ifrån arbetsmarknaden bedöms kräva en så gedigen insats innan "avkastningen", i form av att personen sysselsätts, kommer.

Inrättandet av STAR uppges i intervjuer i praktiken ha medfört att det kommit större fokus på praktisk implementering och förankring av reformer inom arbetsmarknadsområdet, och dialogen mellan stat och kommun har på så vis även ökat. STAR har en viktig roll i att vägleda kommunerna till de mest effektiva åtgärderna genom att tillhandahålla kunskap och råd. Det finns bland annat en implementeringsguide som STAR har publicerat som visar reformarbetet ska gå till och hur STAR kan assistera i implementering. Det gäller således för varje reform som Folketinget beslutar om. ${ }^{129}$

Utvecklingen mot en mer evidensbaserad styrning har möjliggjort att man på lokal nivå upplever sig under senare år ha en fått ett större utrymme att utifrån handläggarnas individuella bedömning välja lämpliga åtgärder, i jämförelse med den strikta målstyrningen som inledningsvis styrde de nyetablerade jobcentren. En motsägelsefull utveckling är dock att de med Beskæftigelsesreformen införda reglerna strikt regerar tätheten på uppföljningssamtal, istället för att förlita sig på handläggarens och kundens bedömning om hur tätt dylika träffar kan behövas.

I början av 2000-talet gick Danmark in för att upphandla en stor del av verksamheten till privata aktörer. Trenden vändes dock då den socialdemokratiskt ledda regeringen tillträdde 2011, då kommunernas måltal om andelen upphandlade aktörer avskaffades. Numera är det upp till kommunerna att välja om de vill anlita upphandlade aktörer. Generellt har andelen upphandlad verksamhet sjunkit, men variationen mellan kommunerna är stor. Skillnader i effekt mellan upphandlad verksamhet och kommunala insatserna vet man dock lite om.

\subsection{Finland}

Som ovan visats har de finska reformerna i stor utsträckning rört själva servicestrukturen inom arbetsmarknadspolitiken. En utvärdering som genomfördes strax efter implementeringen av reformen 2007, visar på att uppdelningen av arbetsmarknadsåtgärder enligt målgrupp i huvudsak varit lyckad. ${ }^{130}$ Reformen innebar att de som står långt ifrån arbetsmarknaden styrdes till de s.k. servicecentren för arbetskraften medan AN-byråerna i högre grad fokuserade sin verksamhet mer på renodlad arbetsför-

\footnotetext{
${ }^{129}$ STAR Implementeringsguide 3.o (juni 2016). http://star.dk/da/Om-STAR/Publikationer/2016/Implementeringsguideversion-3.aspx

${ }^{130}$ Valtakari, Syrjä \& Kiuru, 2008.
} 
medling för dem som är "jobbredo". Reformen ledde framförallt till en effektivisering av rehabiliteringen och aktiveringen av dem som står längst ifrån arbetsmarknaden. Servicecentren fungerade väl i att förbättra samverkan mellan kommun, stat och ett bredare nätverk och mottogs väl av kunderna. Utvärderingen pekar dock även på negativa aspekter: samverkan mellan Servicecentren för arbetskraften och AN-byråerna konstaterades vara bristfällig och sammantaget kom utvärderingen fram till att det finns stor förbättringspotential i att tillmötesgå såväl arbetsmarknadens som kundernas behov.

I en effektivitetsrevision från Statens revisionsverk konstateras att inrättandet av Servicecenter för arbetskraften (TYP) har inneburit att samarbetet mellan staten och kommunerna har breddats och att kommunerna deltar aktivare än förut i försöken att råda bot på långtidsarbetslösheten. ${ }^{131}$ I samma revision konstateras också att de eftersökta synergifördelarna med att integrera arbetskrafts- och näringspolitiken genom bildandet av det nya Arbets- och näringsministeriet inte realiserats eller bidragit till att bättre sysselsätta dem som har varit länge arbetslösa, eftersom arbetsmarknadspolitiken i huvudsak har fokuserat på själva arbetskraftsutbudet. Speciellt vad gäller sysselsättning av långtidsarbetslösa uppges det huvudsakliga problemet vara brist på arbetsplatser med låg tröskel - den vanligaste vägen in på arbetsmarknaden för långtidsarbetslösa - och mer konkret samarbete med såväl företag och som offentliga arbetsgivare efterfrågas för att bättre möta efterfrågan på sådana arbetsplatser. Sammantaget konstateras att effekterna av de aktiva åtgärderna för långtidsarbetslösa sannolikt är tämligen små. ${ }^{132}$

Reformen av AN-byråerna som genomfördes 2013 beskrivs av intervjurespondenterna i hög grad som en administrativ reform, men den hade även bäring på servicestrukturen. En omfattande utvärdering av reformerna visar att uppdelningen av servicen i flera kanaler ännu inte visat sig fungera väl, utan behöver utvecklas vidare. Trots utökade digitaliserade tjänster kvarstår behovet av personliga tjänster. ${ }^{133}$ Resultat av reformen påverkas dock av att det skurits ned på AN-byråernas resurser, samtidigt som antalet arbetslösa har ökat. Intervjuer på lokal nivå pekar på att utvecklingen av e-tjänster i Finland i stor utsträckning kommit att användas som ett substitut till personlig service, snarare än som ett komplement. Detta förefaller dock framförallt vara på grund av resursbrist till följd av landets ansträngda ekonomi, snarare än ett medvetet val av just användningen av e-tjänster. I praktiken betyder det att personer

\footnotetext{
${ }^{131}$ Statens revisionsverk, 2011, s. 52.

https://www.vtv.fi/files/2650/2292011_Pitkaaikaistyottomien_tyollistyminen_netti.PDF

${ }^{132}$ Statens revisionsverk, 2011, s. 93

${ }^{133}$ Valtioneuvosto (2016). Työpolitiikan vaikuttavuus ja vaihtoehdot Tutkimus työpoliittisten toimenpiteiden toimivuudes-

ta, tuloksista ja tulevaisuudesta (TYVA). Valtioneuvoston selvitysja tutkimustoiminnan julkaisusarja 3/2016.
} 
som står nära arbetsmarknaden i praktiken aldrig träffar en handläggare, utan att all service kanaliseras via internet eller telefon. ${ }^{134}$

Utvecklandet av servicemodellen i tre linjer har därmed inte fungerat som tänkt, utan visat sig vara för stelbent $i$ och med att själva arbetsförmedlingen isolerats till en egen linje, och inlåsningseffekter i de respektive linjerna kunnat skönjas. ${ }^{135}$ Kundorienteringen har försvagats, samtidigt som utbudet av tjänster har minskat. Andelen traditionella arbetskraftspolitiska insatser som subventionerade anställningar och arbetskraftspolitisk utbildning har minskat samtidigt som andelen rehabilitering och med arbetslöshetsförmån finansierad reguljär utbildning har ökat. Sammantaget visar statistiken att tyngden i arbetsmarknadspolitiken har flyttats mot passiva förmåner istället för aktiva insatser. ${ }^{136}$

Den integrering av arbets- och näringslivspolitiken som eftersträvades i samband med bildandet av det nya Arbets- och näringsministeriet har enligt utvärderingar inte till fullo realiserats, ens på ministerienivå. ${ }^{137}$ Istället har sammanslagningen lett till att arbetsmarknadspolitiken blivit mer otydlig och att det saknas ett helhetsperspektiv. Flera av intervjurespondenterna betonar att det finns mycket att göra för att förbättra synergierna mellan arbets- och näringslivspolitiken, men en positiv effekt av integreringen anges dock vara att AN-byråerna i högre grad arbetar gentemot arbetsgivare och har större kontakt med företag än vad som tidigare var fallet.

Utvärderingar av styrningen av arbetsmarknadspolitikens servicestruktur visar på att styrningen av arbetsmarknadspolitiken är splittrad, med otydlig ansvarsfördelning mellan inblandade aktörer. Vid sidan av "traditionell" politisk, lagstiftnings- och resursstyrning har ministeriet även en stor roll i informationsstyrning, som i praktiken bl.a. tar sig uttryck i administrativa anvisningar om hur lagstiftningen ska implementeras på lokal nivå. Ofta är dessa väldigt detaljerade och omfattande, oförutsebara i tajmingen och anses sammantaget begränsa de regionala AN-byråernas arbete. ${ }^{138}$ Enligt utvärderingen är detta en naturlig följd av att Finland i motsats till de flesta andra länder saknar en nationell central myndighet som kan delta i styrningen. Den regionala NTM-strukturen anses inte vara ändamålsenlig för att lätta på ministeriets börda. ${ }^{139}$ Inrättandet av KEHA-centret har enligt intervjurespondenterna även i viss

\footnotetext{
${ }^{134}$ Intervjuer med lokala AN-byråer.

${ }^{135}$ Valtioneuvosto (2016), s. 133.

${ }^{136}$ Valtioneuvosto (2016), s. 131

${ }^{137}$ Oosi, Olli (2012). Työvoimapolitiikan suunnittelu- ohjaus- ja organisaatiomallin arviointi. Työpoliittinen Aikakausikirja 2/2012. s. 64-77.

${ }^{138}$ Oosi, Olli (2012). Työvoimapolitiikan suunnittelu- ohjaus- ja organisaatiomallin arviointi. Työpoliittinen Aikakausikirja 2/2012. s. 64-77.

${ }^{139}$ Arbets- och näringsministeriet, Työpolitiikan palvelurakennearviointi: Työpolitiikan palvelurakenteen ohjaus ja kolmikantayhteistyö Valmisteluryhmän raportti. 28.10.2014.s. 10.
} 
mån komplicerat styrningen. Även om centret till viss del saknar formellt, strategiskt, styrningsansvar har centraliseringen av flera förvaltningsprocesser gjort att centret $\mathrm{i}$ praktiken kommit att bli ytterligare en aktör som styr AN-byråerna.

$A v$ intervjurespondenterna framgår att arbetsmarknadsförvaltningen alltid varit toppstyrd, men att AN-byråernas autonomi minskat något över tid. Den lokala anpassningsförmågan anses däremot finnas kvar i relativt hög utsträckning. Av intervjuer på regional och lokal nivå framkommer även tydligt att nedskärningar i resurser har haft en stor inverkan på de praktiska förutsättningarna att implementera arbets- och näringsservicen. De lokala kontoren har exempelvis relativt stor flexibilitet i vilka typer av åtgärder de kan erbjuda arbetssökande, och överlag uppfattas de tillgängliga "verktygen" vara relevanta och tillräckliga. I praktiken förekommer det dock att exempelvis budgeten för att anskaffa utbildningar tar slut innan året är slut, vilket betyder att tillgängligheten av åtgärder för den enskilda arbetssökande kan variera mellan vår och höst.

En utvärdering av servicestrukturen framhåller en övergripande motstridighet $\mathrm{i}$ den finska arbetskraftspolitiken: medan det i servicestrukturen eftersträvas mer nätverkande, individanpassning och innovation, så har den centrala administrationen i högre grad betonat en enhetlighet i servicen, centralisering och effektivitet. Samtidigt pågår flertal förnyelseprocesser som drar åt olika håll. ${ }^{140}$

\subsection{Island}

Som ovan konstaterats har Island inte präglats av reformer i organisation och styrning på samma sätt som de andra nordiska länderna. Mindre justeringar av ansvaret inom särskilda målgrupper, såsom funktionshindrade, har gjorts. Den stora förändringen under senare år är dock allt som skett efter finanskrisen 2008. Den plötsligt kraftiga ökningen av arbetslöshet som uppstod till följd av finanskrisen 2008 utgjorde en stor omvälvning för landets arbetsmarknadspolitiska förvaltning. Responsen på krisen var snabb och nya aktiva åtgärder implementerades omgående, samtidigt som mycket arbete på den lokala nivån gick åt till grundläggande arbete, som att registrera arbetssökande och utbetalning av arbetslöshetsersättning.

Några av de initiativ som då sjösattes har evaluerats på olika sätt. Oftast har det dock skett genom till exempel enkäter med deltagarna i olika initiativ, snarare än $\mathrm{i}$ form av effektutvärderingar i egentlig mening. Ett av de initiativen som har undersökts av välfärdsministeriet är Nám er vinnandi vegur, som enligt de intervjuer med

\footnotetext{
${ }^{140}$ Työpolitiikan palvelurakennearviointi: Työpolitiikan palvelurakenteen ohjaus ja kolmikantayhteistyö. Valmisteluryhmän raportti TEM/1165/00.04.03/2013, s.19.
} 
lokala arbetsförmedlare som vi har gjort är ett initiativ som innebar en stor förändring på lokal nivå. Medarbetarna var tvungna att snabbt anpassa sig och lära sig nya initiativ och snabbt få ett stort antal ungdomar i olika typer av utbildning. ${ }^{141}$

Initiativet innebar att unga arbetssökande som uppfyllde villkoren fick en garanterad plats i det ordinarie utbildningssystemet. Under hösten 2011 hade 960 personer deltagit i initiativet (53 procent män och 47 procent kvinnor). Av dem som deltog var 55 procent inskrivna i gymnasieskolor, 12 procent i förberedande arbetsmarknadsutbildning och 33 procent på universitet.

I utvärderingen av initiativet visar det sig att programmet hade färre avbrott än andra program. Närvaron var bättre än i ministeriets övriga utbildningsprogram vilket kan förklaras av de villkor och krav deltagarna måste uppfylla. För att sammanfatta resultaten av programmet var 84 procent av dem som deltog inte är registrerade som arbetslösa 90 dagar efter det att programmet avslutats. Vinnumálastofnun menar att initiativet ökade arbetssökandes potential och att de deltagande har stärkt sin position på arbetsmarknaden.

Enligt intervjurespondenterna har de lokala kontorens autonomi ökat över tid, vilket inledningsvis krävdes för att snabbt kunna reagera på krisen. På den lokala nivån uppges digitala verktyg även ha frigjort resurser, vilket möjliggjort en mer kvalitativ kontakt med de sökande. Vidare har digitala verktyg i form av olika tester introducerats, som hjälp för handläggarens bedömning av lämpliga individanpassade åtgärder. ${ }^{142}$

\section{$8.4 \quad$ Norge}

Den norska NAV-reformen har blivit utvärderad i flera omgångar. Andreassen och Aars $^{143}$ har sammanfattat resultaten av flera av dessa utvärderingar. Den stora bilden visar på att färre har gått från arbetslöshet till arbete, jämfört med situationen innan reformen, och åtminstone under de två första åren efter reformen ökade den genomsnittliga tiden i arbetslöshet. Trenden har emellertid varit positiv de senaste åren, men ligger fortsatt under nivån före reformen. Det bör dock påpekas att jämfört med den tidigare arbetsförmedlingsmyndigheten Aetat har NAV en resurssvagare målgrupp. Då Aetats kunder i huvudsak var personer i "tillfällig" arbetslöshet, har NAV ett större inslag av personer med låg anställbarhet och sjukdom.

\footnotetext{
${ }^{141}$ Intervju med lokala representanter för arbetsdirektoratet Vinnumalastofnun.

${ }^{142}$ Ibid.

${ }^{143}$ Alm Andreassen, T. \& Aars, J., Den store reformen - Da NAV ble til, Oslo: Universitetsforlaget, 2015, s. 89.
} 
Reformen förefaller ha lyckats i målet att förhindra att individer faller mellan stolarna: färre faller mellan de olika ersättningarna eller blir helt och håller utan ersättning. Reformen har medfört ökade aktivitetskrav för mottagarna av ekonomiskt bistånd och utvärderingarna visar att reformen de facto haft en positiv inverkan på socialbidragstagare och arbetslösa vad gäller övergång till arbete. För socialbidragstagare infördes i samband med reformen ett "kvalifiseringsprogram", en individuell sysselsättningsplan som innehåller arbetslivsinriktade aktiviteter, arbetsträning och uppföljning. Således har den organisatoriska reformen åtföljts av att stödet för denna grupp blivit starkare. Utfallet har däremot varit sämre för personer med långvariga hälsoproblem inom rehabiliteringen. Detta hänger samman med en minskning av resurser till denna målgrupp, i och med att en del av resurserna för uppföljningen av personer med rehabiliteringsersättning förflyttats från NAV-kontoren till NAVförvaltningen. På det stora hela har reformen även lett till en sämre kostnadseffektivitet och kundtillfredsställelsen sjönk inledningsvis. Kundtillfredsställelsen har sedermera ökat och låg 2015 på en högre nivå än 2008, då kundnöjdheten mättes för första gången. ${ }^{144}$

Effektstudiene av NAV-reformen er nedslående, alt i alt. Man får inntrykk av at det er blitt bedre etter hvert. Jeg tror det er tilfellet nå. Men det er grenser for hvor lenge man klarer å spore en effekt. Vi får nok aldri helt svaret på de direkte effektene. Det er mange andre ting som spiller inn, og det er vanskelig å undersøke. (Simen Markussen, forskare vid Frischcentret)

Digitaliseringen av tjänster har enligt intervjurespondenterna inte kommit så långt $\mathrm{i}$ Norge, men utveckling av självbetjäningstjänster uppges ändå ha underlättat kontakten med arbetssökande kunder. Detta har i viss mån frigjort resurser bland personalen att arbeta för de kunder som inte använder sig av digitala lösningar. I Norge har digitaliseringen använts som ett komplement i kundbetjäningen och har inte varit kopplad till nedskärningar i annan typ av service (vilket varit fallet i Finland).

NAV-reformens ökade fokus på "arbetslinjen" medförde även att styrningen kopplades samman med åtgärdsfokuserade resultatmål. En negativ effekt av detta uppges i praktiken vara att NAV-kontoren i större utsträckning kommit att fokusera på antalet genomförda åtgärder, snarare än att resultatet av åtgärderna - dvs. att kunderna faktiskt kommer ut i arbete. ${ }^{145}$ Styrmekanismerna har visat sig vara svårförenliga med målsättningen om att erbjuda individanpassade åtgärder. Regeringen har således i en melding till Stortinget i maj 2016 uttalat en önskan om att trappa ned på

\footnotetext{
${ }^{144}$ ASD (2016) NAV i en ny tid - for arbeid og aktivitet. Meld. St. 33 (2015-2016). Melding til Stortinget. Arbeids- og Sosialdepartementet.

${ }^{145}$ Intervju med kunskapsdirektör Yngvar Åsholt.
} 
aktivitetsfokusen i styrningen till fördel för resultatstyrning. ${ }^{146}$ På lokal nivå efterfrågas mer flexibilitet och frihet i resursanvändningen: en strikt central styrning och medel öronmärkta till speciella grupper upplevs som utmaningar på den lokala nivån. Tidigare utvärderingar pekar också på utmaningar relaterade till att förena kommunal och statlig styrning på de lokala NAV-kontoren, där de statliga aktörerna haft svårt att acceptera behovet av att ta lokala förhållanden och praxis i beaktande, då detta inte tidigare varit nödvändigt. ${ }^{147}$ Även nätverksarbete på regional och lokal nivå styrs i hög grad uppifrån.

Ett problem vid implementeringen av reformen uppges även ha varit att NAVkontoren belastades med allt för många uppgifter, vilket ledde till att en del av verksamheten kom att outsourcas till privata aktörer. Så skedde bland annat i stor utsträckning med arbetsgivarkontakter, och såväl intervjuer som andra studier visar att arbetet gentemot arbetsgivare sammantaget blev nedprioriterat efter etableringen av $N A V .{ }^{148}$ Färre arbetsgivarkontakter uppges i sin tur ha lett till en försämrad kunskap om arbetsmarknaden på NAV-kontoren. Bland nya förslag till utveckling av NAV anges att arbetsgivarnas behov inte kartläggs i tillräcklig utsträckning. Ett förstärkt fokus på arbetsgivare är således även det ett utvecklingsområde enligt regeringen. Precis som i Finland finns i Norge förslag om ökat samarbete med bemanningsföretag för att effektivisera matchningen på arbetsmarknaden. ${ }^{149}$

\subsection{Sverige}

Tidiga utvärderingar av effekterna av inrättandet av myndigheten Arbetsförmedlingen visar på att den nya organisationen löst flera av de organisatoriska och styrrelaterade problemen som fanns i den tidigare, mer splittrade, organisationen och att det därmed skapades bättre förutsättningar för att få ett ökat genomslag för den statliga arbetsmarknadspolitiken. Strukturen med en samlad myndighet ansågs också skapa bättre förutsättningar för ett bättre nyttjande av resurser, i och med att fördelningen av resurser sker på nationell nivå. ${ }^{150}$ En av målsättningarna med reformen var även att

\footnotetext{
${ }^{146}$ Meld. St. 33 2015-2016, NAV i en ny tid - for arbeid og aktivitet, s.10.

${ }^{147}$ Larsen, H., Malmberg-Heimonen, I., Johannessen, A. (2012). Kunnskapsoppsummering om partnerskap mellom stat og kommune i NAV-kontorene.

${ }^{148}$ Se bl.a. NAVs formidlings- og rekrutteringstjenester, AFI-rapport 14/2014 och Ekspertgruppen (2015), Et NAV med muligheter. Bedre brukermöter, större handlingsrom og tettere på arbeidsmarkedet, s. 43.

${ }^{149}$ Meld. St. 33, NAV i en ny tid - for arbeid og aktivitet, s. 11, samt Ekspertgruppen (2015), Et NAV med muligheter. Bedre brukermöter, större handlingsrom og tettere på arbeidsmarkedet., s. 43.

${ }^{150}$ Ernst \& Young (2009). Utvärdering av implementeringen av nya Arbetsförmedlingen. Slutrapport. s. 2.
} 
myndighetens fokus på arbetsförmedling samt matchning mellan lediga arbeten och arbetssökande skulle öka. Några entydiga bevis på förändringar i matchningseffektivitet kunde däremot inte fastställas i den utvärdering av implementeringen av den nya myndigheten som gjordes. ${ }^{151}$

Målsättningen om att få en mer enhetlig och likvärdig arbetsförmedling nåddes således, då styrbarheten förenklades och förbättras i samband med inrättandet av den nya myndigheten. ${ }^{152}$ Den kraftiga centraliseringen tog sig dock uttryck i en detaljstyrning med flera negativa effekter. Enligt en analys av Arbetsförmedlingens interna styrning och utvecklingsarbete kom myndigheten att präglas av en omfattande detaljstyrning, vilket ledde till långa beslutsprocesser, en överprövningskultur och en otydlighet i styrningen som saknade helhetsperspektiv. ${ }^{153}$ Arbetsförmedlingen bedrev inte heller någon systematisk uppföljning och analys av verksamheten, vilket innebar att lärdomar inte i tillräcklig utsträckning fångades upp. ${ }^{154}$

Det pågående arbetet med att minska den detaljerade styrningen och öka delegeringen av verksamhetsansvar anses av Statskontoret vara ett steg i rätt riktning, och utvecklingen bedöms också som positiv av intervjurespondenter på samtliga nivåer. Enligt intervjuer på den lokala nivån så har den pågående "Förnyelseresan" av Arbetsförmedlingen, inkluderat förnyelsen av den interna styrningen av myndigheten, lett till att de lokala kontoren fått betydligt större autonomi. Detta innebär enligt respondenterna att de har betydligt bättre förutsättningar att anpassa servicen till kundernas behov och önskningar, än vad som varit fallet tidigare då kontoren i högre grad detaljstyrts. Skiftningen i styrningen från en strikt "uppifrån-och-ner" perspektiv till en styrning där den lokala nivån har större frihet att tillämpa sin professionella bedömning exempelvis i val av åtgärder, uppfattas som mer effektivt och ändamålsenligt av flera respondenter. ${ }^{155}$

De första upphandlingarna av kompletterande aktörer präglades av vissa kvalitetsbrister, vilket i utvärderingar uppges ha haft ett samband med regeringens redan initialt högt ställda volymmål och avsaknaden av systemstöd för den omfattande upphandlingen. ${ }^{156}$ Utvärderingar av effekten av användningen av kompletterande aktörer visar inga varaktiga effekter av samverkan med kompletterande aktörer på utflödet till arbete inom jobb- och utvecklingsgarantin. En studie visar visserligen att

\footnotetext{
${ }^{151}$ Ernst \& Young (2009). Utvärdering av implementeringen av nya Arbetsförmedlingen.Slutrapport. s. 23.

${ }^{152}$ Sjöberg, Mikael, generaldirektör \& Olsson, Clas, biträdande generaldirektör Arbetsförmedlingen. Intervju 2015-12-09

${ }^{153}$ Statskontoret 2016, s. 29.

${ }^{154}$ Statskontoret 2016, s. 7 .

${ }^{155}$ Intervjuer med Cristofer Almert och Moa Hellerström.

${ }^{156}$ Ernst \& Young (2009). Utvärdering av implementeringen av nya Arbetsförmedlingen.

Slutrapport. S. 40
} 
utflödet till arbete från kontor som har samverkat med kompletterande aktörer inom jobb- och utvecklingsgarantin, i genomsnitt, ökat initialt jämfört med utvecklingen för övriga kontor men den positiva effekten minskade över tid och på sikt gick det inte att återfinna några skillnader mellan de kontor som har och de som inte har samverkat med kompletterande aktörer. ${ }^{157}$ I en forskningsöversikt (Lundin 2011) dras slutsatsen att det inte finns några klara belägg för vare sig starka positiva eller negativa effekter av marknadslösningar inom arbetsmarknadspolitikens område. ${ }^{15^{8}}$ Utöver små eller obefintliga skillnaderna när det gäller den genomsnittliga effektiviteten hos kompletterande aktörer jämfört med Arbetsförmedlingen, finns det dock vissa resultat som pekar på skillnader för undergrupper. Bland annat finns det positiva resultat för kompletterande aktörer för utrikesfödda men negativa resultat för ungdomar, när det gäller den centrala uppgiften att få folk i arbete. ${ }^{159}$ Riksrevisionen har även i en rapport om jobb- och utvecklingsgarantin lyft problem med att Arbetsförmedlingen har svårt att kontrollera kompletterande aktörer, såväl i upphandlings- och genomförandefasen. En ökad kontroll riskerar dock att just den flexibilitet man söker med upphandlad verksamhet inte längre kan uppnås. ${ }^{160}$

En av de mer negativa effekterna av centraliseringen av arbetsmarknadsinsatserna till Arbetsförmedlingen var att samverkansytan på regional och lokal nivå påverkades, då mycket makt flyttades över till central nivå. Kartläggningar från Sveriges Kommuner och Landsting (SKL) visar bland annat att många kommuner vill ha ett större inflytande över arbetsmarknadspolitikens lokala utformning. Svårigheterna för så kallade utsatta grupper på arbetsmarknaden har lett till ett ökat behov av samverkan mellan kommuner och arbetsförmedlingar. En effekt av åtstramningarna i den svenska arbetslöshetsersättningen - en del av "arbetslinjen" - är att många arbetslösa inte uppfyller villkoren i arbetslöshetsförsäkringen. Under 2010 hade drygt 40 procent av dem som fick ekonomiskt bistånd från kommunen arbetslöshet som sitt huvudsakliga försörjningshinder. ${ }^{161}$ I en statlig utredning om arbetslöshet och ekonomiskt bistånd konstateras att Arbetsförmedlingen inte erbjuder arbetslösa personer med ekonomiskt bistånd stöd i samma omfattning som arbetslösa personer med arbetsmarknadsrelaterade ersättningar. Vidare finns det stor variation mellan vilka insatser som

\footnotetext{
${ }^{157}$ Harkman, A. Mikkonen, M., Okeke, S. (2010). s. 18.

${ }^{158}$ Lundin M (2011), Marknaden för arbetsmarknadspolitik: Om privata komplement till Arbetsförmedlingen, Rapport 2011:13, Institutet för Arbetsmarknads- och utbildningspolitisk utvärdering (IFAU), Uppsala.

${ }^{159}$ Se bl.a. Bennmarker, H., Grönqvist, E., Öckert, B., (2009). Betalt efter resultat - utvärdering av försöksverksamhet med privata arbetsförmedlingar. IFAU Rapport 2009:23.

${ }^{160}$ Riksrevisionen (2009). Jobb- och utvecklingsgarantin - en garanti för jobb? Rapport till regeringen, Arbetsmarknadsdepartementet. Dnr: RiR 2009:22. Stockholm: Riksrevisionen. S. 9-10.

${ }^{161}$ Mörk, Eva, Från försörjningsstöd till arbete - Hur kan vägen underlättas? IFAU Rapport 2011:6, s. 10; s. 22.
} 
erbjuds på kommunal nivå, vilket lett till bristande likvärdighet i tillgång till åtgärder för arbetssökande. ${ }^{162}$ Detta håller nu på att repareras med ökat fokus på samverkan med kommuner. ${ }^{163}$

Den satsning på ökat fokus på arbetsgivare som Arbetsförmedlingen inledde 2014 har enligt Arbetsförmedlingens egen analys ännu inte visat några större effekter. ${ }^{164}$ Andelen missnöjda arbetsgivarkunder anges visserligen kunna härledas till en stärkt konjunktur där konkurrensen om arbetskraften ökar samtidigt som andelen av de arbetssökande som står långt från arbetsmarknaden också ökar. Att förbättra matchningen mellan arbetsgivare och arbetstagare uppges vara en av Arbetsförmedlingens främsta utmaningar. ${ }^{165}$

${ }^{162}$ SOU 2015:44 Arbetslöshet och ekonomiskt bistånd. Betänkande av Utredningen om stöd och krav avseende arbetslösa personer som tar emot ekonomiskt bistånd.

${ }^{163}$ Sjöberg, Mikael, generaldirektör \& Olsson, Clas, biträdande generaldirektör Arbetsförmedlingen. Intervju 2015-12-09.

${ }^{164}$ Arbetsförmedlingen (2016) Arbetsförmedlingens arbetsgivarkontakter.

${ }^{165}$ Arbetsförmedlingen (2016) Arbetsförmedlingens arbetsgivarkontakter. 


\section{Slutsatser - effekter av reformer och skillnader i styrning}

Syftet med denna studie är att undersöka om organiseringen och styrmekanismer har någon betydelse för utfallet av arbetsmarknadspolitiken. Ger modell A större måluppfyllelse än modell B? Ger en åtgärd eller reform i system $A$ andra resultat och effekter än en åtgärd eller reform i system B? Det har visat sig vara svår uppgift att ge ett rakt svar på de frågorna. Det görs i Norden endast få effektutvärderingar eller andra typer av utvärderingar av organisatoriska eller styrningsrelaterade reformer, som kapitel åtta visade. Bildandet av NAV är ett undantag som bekräftar regeln. De studier av arbetsmarknadspolitiken i Norden som görs är i allmänhet inriktade på specifika åtgärder i isolerade system, som det är svårt att generalisera ifrån. Trots dessa brasklappar skal detta kapitel åtminstone vända på alla kort för att försöka bidra till svar på de frågor som ställts.

Kapitlet har tre delar, den första går igenom styrning och reformer från ett centralt perspektiv. ${ }^{166}$ Det begrundar skillnader i reformtäthet och vad det har fått för konsekvenser, effekter av olika typer av styrning och vad forskningen säger om den typ av system och reformer som finns i Norden.

Den andra delen av detta kapitel behandlar de stora förändringar som gjorts i Norden avseende centralisering visavi decentralisering samt kommunernas skiftande roll i arbetsmarknadspolitiken i Norden. Eftersom vissa av de passiva och sociala välfärdstjänsterna ligger på kommunalt ansvar behandlas även kopplingen mellan de aktiva och de passiva systemen i denna del.

Slutligen kommer den del där rekommendationer ges om vad de Nordiska länderna kan lära av varandra.

\footnotetext{
${ }^{166}$ I normala fall introduceras inte ny information i slutsatskapitlet. I detta kapitel refereras dock till en del akademisk litteratur och annan forskning som inte presenterats tidigare. Detta beror på att de tidigare kapitlen haft fokus mer på empiri än på teori.
} 


\subsection{Styrning och organisering på central nivå}

En genomgång av de reformer som gjorts under det senaste decenniet visar att styrningen och organiseringen av arbetsmarknadspolitiken är under en nästan ständig omvandling. Det mest extrema exemplet har varit Finland, med återkommande justeringar av ansvarsfördelning och aktörers roll och utbud av tjänster. Island har befunnit sig på motsatt sida av skalan, med relativt få förändringar i systemet. Den övergripande trenden i Norden har varit mot en centralisering av styrningen, men med bibehållet eller stärkt lokalt mandat. Trots denna trend har olikheterna kommit att öka i Norden. Skillnaderna mellan till exempel det norska systemet och det finska är nu omfattande. De stora och ökande skillnaderna mellan länderna gör det svårare för ländernas ministerier och andra aktörer att lära av varandras erfarenheter. Å andra sidan är spektrumet av potentiella lärdomar allt bredare, eftersom staterna provar en mängd olika modeller för organisering och styrning.

De reformer som gjorts har varit svar på olika utmaningar i de olika länderna. I Sverige och till viss del i Danmark har de varit en följd av politiskt motiverade beslut, ofta som en följd av regeringsskifte (i Danmark har de dock ingåtts av breda koalitioner av partier). I Finland och Island har det till större del varit yttre omständigheter som tvingat fram reformer, såsom finanskrisen i Island med kraftigt ökad arbetslöshet som följd och den dåliga ekonomiska utvecklingen i Finland med mindre resurser till arbetsmarknadspolitiken.

Organisatoriska sammanslagningar ger, åtminstone på kort och medellång sikt, sällan de resultat som det var tänkt. Det finns många exempel på det i Norden, nya arbets- och näringsministeriet i Finland, NAV i Norge som hade en lång startsträcka, där färre kommer i arbete än innan reformen. Däremot har bildandet av NAV åtgärdat det problem som finns i alla nordiska länder, att personer hamnar mellan stolarna och skickas runt mellan myndigheter, som Svarte Petter. Sammanslagningar och organisatoriska förändringar bör dock användas med försiktighet. De kan bidra till att förenkla för medarbetaren genom en-dörrs-lösningar (one-stop-shop). Det verkar ha bäst effekt för dem som står långt från arbetsmarknaden, vilka också är prioriterade målgrupper i samtliga länder. Det innebär att det norska exemplet med fördel kan användas som inspiration för andra länder.

Trots en hög reformtakt i Norden har den grundläggande inriktningen på arbetsmarknadspolitiken varit likartad. Det har primärt varit fokus på utbudssidan (det vill säga de arbetssökande och deras förmåga och incitament till arbete) och bara sekundärt på efterfrågesidan (det vill säga arbetsgivare och näringslivet och viljan att anställa). Finland står dock ut i och med att man där kopplat samman arbetsmarknadspolitik och näringslivspolitik, både genom sammanslagning på depar- 
tementsnivå och genom den ökade rollen för NTM-centralerna. Med detta sagt har trots allt de flesta av de fem länderna under det senaste decenniet fokuserat på arbetsförmedlingen i riktning mot fler arbetsgivarkontakter för att på så sätt förbättra matchningen på arbetsmarknaden. Det märks tydligt i Finland och Sverige, men också i Danmark och på Island. Mismatchning är ett gemensamt problem på arbetsmarknaden i Norden, som adresseras genom mer fokus på arbetsgivarna. Däremot inte i Norge i samma utsträckning, men där är man å andra sidan i startgroparna för att satsa mer på arbetsgivarkontakter i framtiden, enligt slutrekommendationerna från expertgruppen om NAV.

De länder som avviker mycket på ett specifikt område kan således förväntas återkomma till mitten av strömfåran inom en viss tid. Det finns fler exempel på det än Norge, och flera intervjuade på högt uppsatta positioner inom respektive myndighet uppger att man sneglar på lärdomar från övriga nordiska länder. Studiebesök och liknande är också vanligt. Man kan konstatera att de Nordiska länderna alla uppvisar olikheter, men att systemen ändå fungerar. Det finns inte en universallösning som passar alla länder.

I såväl Danmark och Norge som Sverige har strävan efter en starkt kontrollerad politik lett till att man först implementerat en strikt målbaserad styrning. I samtliga länder har styrmekanismerna ändå på senare år konstaterats alltför rigida: styrningen har fått en kontraproduktiv effekt, där fokus inom politikområdet i alltför hög grad kommit att fokusera på att uppfylla detaljerade, åtgärdsspecifika målsättningar, vilket motverkat möjligheten till den anpassning till såväl lokala förutsättningar som individuella behov som en effektiv arbetsmarknadspolitik kräver. Styrmekanismens utformning är således av största vikt för att uppnå denna balans - vilket konstaterats i alla tre länder där en utveckling mot en mer resultatbaserad styrning nu är på gång. Framförallt i Danmark, men även i Norge och Sverige eftersträvas nu en mer evidensbaserad politik, där mål snarare än medel är i fokus. Bland annat OECD har betonat vikten av att den lokala nivån i implementeringen av arbetsmarknadspolitiken har tillgång till centralt administrerade resurser och forskningsresultat om effektiva åtgärder, som kan stå till grund för en anpassning till lokala förhållanden och lämna handlingsutrymme för försöksverksamhet. ${ }^{167}$

I de länder som nyligen svängt mot mer evidensbaserad politik finns få eller inga utvärderingar kring hur detta fungerar ännu. Framförallt i Danmark är den utvecklingen ändå baserad på ett gediget forskningsunderlag (Carsten Koch-utvalget), och det mesta tyder på att evidensbaserad politik - med exempelvis professionaliserade samtal i mö-

\footnotetext{
${ }^{167}$ OECD (2005), Employment Outlook, s. 215.
} 
ten med klienter - fungerar. En sådan ambition om att höja kvaliteten genom evidensbaserad politik kan dock stå i motsättning till ökad lokal autonomi och förtroende för att enskilda anställda är i stånd att göra den bästa bedömningen. Det är dock värdefullt och uppskattat för den enskilda arbetsförmedlaren, enligt de studier som gjorts och vilket våra intervjuer bekräftar, att väl beprövade åtgärder och insatser finns i verktygslådan, så länge det är upp till den egna bedömningen om insatsen ska användas eller ej.

Ekonomiska incitament som inslag i styrningen har implementerats i Norden under den undersökta perioden, i mest renodlad form i Danmark. I både Finland och Norge upplevs de ekonomiska incitamenten snarare gå i motsatt riktning. De regioner/kontor/kommuner som har en svår situation får mer pengar än de andra. "Men om du gör ett bra resultat och arbetslösheten minskar och indikatorerna visar grönt på alla nivåer, så kan leda till att du får mindre och mindre pengar" som en lokal chef i Finland uttryckte det. Det danska refusionssystemet reformerades parallellt med denna studie, och dess effekter går ännu inte att uttala sig om.

Ekonomiska incitament med direkt eller indirekt verkan på kommunernas utgifter har i fyra av fem länder (Finland, Danmark, Island och Sverige) ökat kommunernas roller i aktiveringen av arbetslösa. Ekonomiska incitament används i syfte att minska arbetslösheten men eftersom sådana incitament i Finland, Island och Sverige inneburit ökade kostnader för kommunerna har de varit tvungna att bli aktiva aktörer inom arbetsmarknadspolitiken, om de inte redan varit det. Det har fungerat relativt väl på Island och i Sverige, där den statliga aktören värnat ett mer dynamiskt samarbete med kommunerna. I Finland har bilden varit mer komplicerad eftersom arbetskraftspolitiken samtidigt har fått en mer regional tyngd, med AN-byråer och NTM-centraler på regional nivå ansvariga för den mesta styrningen av de lokala kontoren.

Inte bara de intervjuer som har gjorts i denna studie, utan också den forskningslitteratur som finns på området varnar för ekonomiska incitament som styrmedel i en styrkedja med offentliga eller upphandlade aktörer. Europeiska Kommissionens utredare Alex Nunn, professor vid Leeds Metropolitan University menar till exempel att ekonomiska belöningar och bestraffningar bör användas med extrem försiktighet:

"Extreme care is required with the use of sanctions and rewards in relation to performance management: The evidence from the small number of countries that have implemented contracted-out payment by results systems suggests that this has had only mixed success in achieving the theoretical benefits from such systems. More time is required to judge conclusively the effects of these systems, but they may not be suitable for PES." ${ }^{168}$

${ }^{168}$ Nunn, Alex (2012), s. 33. 
Ekonomiska incitament i styrningen kan vara effektivt, men, denna studie har visat att det också riskerar leda till snedvridet fokus på dem som står nära arbetsmarknaden. Incitamentstrukturer kan leda till icke önskvärda snedvridningar i målgrupper. Till och med väldigt detaljerad uppföljning, med indikatorer för olika målgrupper etc., kan få snedvridande effekter, även utan ekonomiska incitament kopplade till styrningen.

I samtliga nordiska länder har privata aktörer involverats i någon grad i implementeringen av arbetsmarknadspolitiken. Det är dock svårt att dra generella slutsatser kring upphandling av tjänster i sig, utförandet av själva upphandlingen verkar vara av större relevans. I Sverige har man sett negativa effekter av att på kort tid involvera privata aktörer i stor omfattning, då varken marknaden med privata företag som erbjuder tjänster eller den upphandlande aktören varit mogna.

Sverige är det enda land som styrt starkt mot upphandling av privata aktörer. Den typen av detaljstyrning av hur myndigheten skulle använda sina resurser gav mestadels negativa eller som bäst neutrala effekter enligt utvärderingar. Å andra sidan finns det nu en större mångfald av aktörer med erfarenhet av att arbeta med sysselsättningsåtgärder på olika sätt, vilket kan ha varit den dåvarande regeringens verkliga motiv.

Forskningen är ambivalent vad gäller nyttan med upphandlade aktörer inom arbetsmarknadspolitiken, och det går utanför denna studies syfte att ge ett svar på den frågan. Det kan dock konstateras att det finns en potential för effektivitetsvinster tack vare privata aktörer. En studie gjord av det nätverk för ömsesidigt lärande mellan statliga arbetsförmedlingar som finns på EU-nivå konstaterar:

"Private providers can, under certain contractual arrangements, improve outcomes for particular groups and bring innovation to service delivery. The competitive pressure they bring may also prompt improved PES performance." ${ }^{169}$

Huruvida systemen och de arbetssökande individerna gynnas av fler privata aktörer beror således inte på om det finns som alternativ eller inte, utan på de offentliga arbetsförmedlingarnas kompetens i att upphandla, styra och följa upp de privata aktörerna.

I många länder är det svårt eller omöjligt att isolera effekten av reformer. Ta de tre servicelinjerna i Finland som exempel, en radikal reform som påverkat målgruppsorientering, kontakten med de arbetssökande, hur de anställda arbetar och så vidare. Det är omöjligt att helt isolera effekterna av denna reform eftersom Finland samtidigt har sett arbetslösheten stiga kraftigt, den statliga ekonomin försämras och arbetsförmedlingens resurser har skurits ned. Inget av detta har varit en följd av re-

\footnotetext{
${ }^{169}$ Finn, Dan (2011) S, 4.
} 
formen, men det gör reformen svårutvärderad, och svår att jämföra med situationen i övriga länder. För att ytterligare komplicera bilden har andra reformer pågått samtidigt, som till exempel en snabb digitalisering av servicen. De utvärderingar som finns visar dock på ett negativt resultat av servicelinjerna, att reformen bidragit till en mindre flexibilitet och inlåsningseffekter både bland personal och arbetssökande.

\subsection{Decentralisering och kommunernas roll}

Forskning visar att tydliga styrkedjor och klara roller, med en fungerande styrkedja hela vägen från departement till implementerande aktörer, är viktig för en effektiv implementering av arbetsmarknadspolitiken.

"Clearly demarcated and hierarchical structures can ensure finding the right balance between cen-

tral guidance and local autonomy. ${ }^{1170}$

Utvärderingarna av effekterna av de reformer som gjorts i Norden visar att det tar lång tid efter en reform innan den typen av klar och tydlig styrkedja gestaltar sig. Det bekräftas också i de intervjuer längs med styrkedjan som gjorts i denna studie.

Avvägningar mellan en styrning som betonar lokal- och individanpassning å ena sidan och en mer centraliserad och likformig styrning å andra sidan kan tänkas ha olika påverkan på olika grupper av arbetslösa. Personer som står längre bort ifrån arbetsmarknaden och mindre arbetsgivare som fungerar lokalt vinner ofta på ett system som i högre grad möjliggör lokal anpassning. ${ }^{171}$

Styrningen påverkar möjligheten till att föra evidensbaserad politik så att målstyrning möjliggör en mer individanpassad och därmed möjligen effektiv arbetsmarknadspolitik. Intervjuer på lokal nivå verkar stödja tanken om att viss grad av autonomi krävs för att kunna erbjuda individualiserad service. Detaljstyrning minskar möjligheten för den enskilda arbetsförmedlaren att göra en professionell bedömning om individuella behov.

"...It is precisely the development of a high quality performance management system - based on high levels of transparency, benchmarking, and robust data, in which ambitious targets are set by

\footnotetext{
${ }^{170}$ Weishaupt, J. Timo, 2014, s. 25.

${ }^{171}$ Työpolitiikan palvelurakennearviointi: Työpolitiikan palvelurakenteen ohjaus ja kolmikantayteistyö. Valmisteluryhmän raportti. TEM 28.10.2014. s. 17-18.
} 
local PES management - that allows for high levels of local autonomy [without compromising national objectives or equal treatment/opportunity principles]. ${ }^{\prime 172}$

Som kapitel fem, sju och åtta visar är detta också den riktning som tagits I de flesta länder. En centraliserad styrning men med gradvis större autonomi för den lokala nivån. Autonomi på lokal nivå bidrar till bättre lokal förankring av arbetsmarknadspolitiken, d.v.s. en politik som bättre svarar mot den lokala arbetsmarknadens behov.

Styrning förankrad i det regionala (ex. genom regionala stakeholder-grupper) möjliggör en mer arbetsmarknadsanpassad politik - vilket i sin tur påverkar effekten:

\footnotetext{
"The local level should benefit from national-level services such as standardized information technology, material for use in training courses and research findings about effective placement strategies, and should also be able to work autonomously to adapt its strategy to unique local conditions and to leave room for experimentation ${ }^{\prime 173}$
}

Kommunen har blivit en viktigare aktör då vissa arbetslösa som av olika anledningar inte längre har rätt till arbetslöshetsersättning eller aktivitetsstöd istället ansöker om försörjningsstöd. De har också involverats på ett mer medvetet och aktivt sätt i de flesta länder. Denna utveckling har haft två separata målsättningar: dels att knyta samman aktiva och passiva åtgärder, dels att möjliggöra mer integrerad service för personer som står långt ifrån arbetsmarknaden och kan tänkas vara i behov av sociala tjänster som ett komplement till arbetsförmedlingens tjänster. I Norge har åtminstone till viss grad positiva effekter av samlokalisering av sociala tjänster (under kommunens regi) och arbetsmarknadstjänster (under statlig regi) påvisats för de målgrupper som står långt ifrån arbetsmarknaden. Dock är det oklart i vilken mån detta är direkta resultat av samordningen i sig, och i vilken grad övriga förändringar i aktiva åtgärder som samtidigt inrättats - som t.ex. skapandet av nämnda kvalificeringsprogrammet - spelat in.

Kommunerna har starka incitament för att få personer med försörjningsstöd i arbete. ${ }^{174}$ Det är då bättre att involvera kommunerna i den statliga arbetsmarknadspolitiken (Danmark, Norge och delvis Finland) än att det uppstår parallellsystem (Sverige, delvis Finland) där det finns en risk att kommunerna huvudsakligen drivs av att minska

\footnotetext{
${ }^{172}$ Weishaupt, J. Timo, 2014, s. 24.

${ }^{173}$ OECD (2005), Employment Outlook, s. 215

${ }^{174}$ Se bl.a Martin, J.P. (2014) Activation and Active Labour Market Policies in OECD Countries: Stylized Facts and Evidence on their Effectiveness. IZA Policy Paper No. 84.
} 
utgifterna snarare än att minska arbetslösheten, och där de åtgärder som initieras inte utformas på ett effektivt sätt. ${ }^{175}$

\subsection{Rekommendationer - Vad kan länderna lära av varandra?}

Trots, eller tack vare, alla olikheter mellan ländernas vägval finns det goda möjligheter att se på de nordiska grannländerna för inspiration om hur arbetsmarknadspolitiken kan utvecklas.

- Initiera ett institutionaliserat samarbete mellan de offentliga myndigheter på nordisk nivå som ansvarar för implementeringen av arbetsmarknadspolitiken. Detta är motiverat dels av potentialen för ömsesidigt lärande, dels av det faktum att Norden har en fungerande gemensam arbetsmarknad som skulle gynnas av ett tätare samarbete mellan dem som arbetar med arbetsförmedling. ${ }^{176}$

- Reformtakten i Norden har generellt varit hög. De intervjuer som gjorts i styrkedjan visar att det ibland har varit svårt för de anställda att hänga med $\mathrm{i}$ svängarna. Ett särskilt stort intresse har visats för olika typer av sammanslagningar av organisationer, som på olika vis har förekommit i varje land. Sammanslagningar kan naturligtvis ha både positiva och negativa effekter, vilket utvärderingar också har visat. Om de bidrar till att minska avståndet mellan passiv och aktiv arbetsmarknadspolitik, skapa en-dörrs-lösningar samt undvika att personer faller mellan stolarna, finns det goda exempel i Norden på att de kan ha positiva effekter. Beslutsfattare bör vara medvetna om att det under en lång övergångsperiod kan ge sämre resultat än före reformen, innan den nya organisationen satt sig. Längden för sådana övergångsperioder kan lätt underskattas.

- En pendelrörelse över tid mellan detalj- eller aktivitetsstyrning och mer återhållsam mål- eller resultatstyrning kan identifieras i Norden. I mitten av ootalet var pendeln långt åt detaljstyrning i princip i hela Norden. Därefter har pendeln rört sig mot en större lokal autonomi, och ett större förtroende för den expertis som finns på lokal nivå i de aktuella myndigheterna. De utvärderingar som finns visar samstämmigt på goda effekter av en ökad lokal autonomi, och

\footnotetext{
${ }^{175}$ Och ofta inte heller ett sätt som är meningsfullt för deltagarna. Intervju med Katarina Thorén som forskat om kommunala arbetsmarknadsåtgärder.

${ }^{176}$ För en längre diskussion om detta, se Nordiska ministerrådet 2016, Olsson, Kullander, Utvärdering av Nordjobb - Nordens arbetsutbytesprogram för unga: TemaNord 2016:522.
} 
större användning av målstyrning snarare än aktivitetsstyrning. Särskilt positivt är detta för dem som står långt ifrån arbetsmarknaden. Därför bör ministerier och andra aktörer uppe i styrkedjan vara försiktiga med nya styrsignaler.

- Användningen av ekonomiska incitament mellan aktörer i systemet samt även rigida uppföljningskrav på aktivitetsnivå kan ge upphov till oönskade snedvridningseffekter. Vanligen yttrar det sig genom att en viss målgrupp prioriteras på ett oönskat sätt på bekostnad av en annan grupp. Det mesta tyder på att tydliga mål för arbetsmarknadspolitiken, uppdelade per målgrupp, är en tillräcklig styrsignal för att olika målgrupper ska prioriteras i önskad utsträckning.

- Effektiviteten i att använda privata aktörer beror i hög utsträckning på de system som finns för upphandling, kontroll, tillsyn, uppföljning och utvärdering från den upphandlande myndighetens sida. Detta skulle kunna vara en första punkt för ett mer institutionaliserat samarbete mellan arbetsförmedlingarna i Norden, där kunskapsutveckling kring privata kompletterande aktörer kan stimuleras.

Åtminstone i Danmark, Finland och Sverige är den juridiska situationen kring dessa upphandlingar snarlik. På sikt kan en nordisk marknad för sysselsättningsåtgärder byggas upp, med mer professionaliserade aktörer som följd.

- Kommunens roll i arbetsmarknadspolitiken har ökat i takt med att "arbetslinjen" gjort att kraven i ersättningssystem under statligt ansvar stramats åt, vilket gjort att fler hänvisas till de ersättningssystem som är kommunens ansvar, till exempel försörjningsstöd. Detta har drivit kommunerna att initiera egna arbetsmarknadsåtgärder i hela Norden. Detta riskerar, särskilt i länder med mindre samarbete mellan arbetsförmedling och kommuner, såsom tidigare var fallet i Sverige till exempel, att skapa parallella system där åtgärderna inte är särskilt effektiva. Därför är det centralt att den statliga arbetsförmedlingen har ett tätt och dynamiskt samarbete med kommuner, och att kommuner har ett inflytande över de arbetsmarknadsåtgärder som sker i den egna kommunen, men med en annan huvudman än kommunen själv. 



\section{Källförteckning}

\subsection{Intervjurespondenter}

Tabell 4: Intervjurespondenter

\begin{tabular}{|c|c|c|c|}
\hline Aktör & Namn & Befattning & Datum för intervju \\
\hline \multicolumn{4}{|l|}{ Danmark } \\
\hline $\begin{array}{l}\text { Kommunernes Landsforening } \\
(\mathrm{KL})\end{array}$ & Kristina Bendixen & $\begin{array}{l}\text { Vice kontorschef för Center for } \\
\text { Vækst og Beskæftigelse }\end{array}$ & 19-nov-2015 \\
\hline Aalborg universitet & Thomas Bredgaard & $\begin{array}{l}\text { Lektor, statsvetenskapliga } \\
\text { institutionen }\end{array}$ & 6-nov-2015 \\
\hline $\begin{array}{l}\text { Beskæftigelsesrådet (Arbets- } \\
\text { marknadsrådet) }\end{array}$ & Carsten Koch & Ordförande & $24-$ nov-2015 \\
\hline STAR & Helle Rasmussen & Vice direktör & 03-nov-2015 \\
\hline Århus kommune & Vibeke Jensen & Beskæftigelseschef & $10-$ nov-2015 \\
\hline $\begin{array}{l}\text { Arbejdsmarkedskontor Midt- } \\
\text { Nord }\end{array}$ & Karl Schmidt & Arbetsmarknadsdirektör & 3-maj-2016 \\
\hline $\begin{array}{l}\text { Beskæftigelsesministeriet/Center } \\
\text { for Arbejdsmarkedspolitik }\end{array}$ & Pernille Harden & Kontorschef & 18-nov-2015 \\
\hline Århus Universitet & Michael Svarer & $\begin{array}{l}\text { Professor, Center for Arbejdsmar- } \\
\text { keds-forskning og effektmåling }\end{array}$ & 04-maj-2016 \\
\hline Hjørring Kommune & Michael Duus Nielsen & Jobcenterchef & $20-\mathrm{maj}-2016$ \\
\hline Frederiksberg Kommune & Anja Krog Svane & Jobcenterchef & 6-jun-2016 \\
\hline Frederiksberg Kommune & Lone Bendz & Handläggare & 25 -jun-2016 \\
\hline \multicolumn{4}{|l|}{ Finland } \\
\hline Arbets- och näringsministeriet & Päivi Kerminen & Regeringsråd & 11 november 2015 \\
\hline Arbets- och näringsministeriet & Heikki Räisänen & Forskningsdirektör & 3 november 2015 \\
\hline Arbets- och näringsministeriet & Jarkko Tonttila & Utvecklingschef & 28 oktober 2015 \\
\hline Nylands arbets- och näringsbyrå & Astrid Tigerstedt & Sakkunnig & 18 maj 2016 \\
\hline Nylands arbets- och näringsbyrå & Niclas Tåg & Servicechef & 17 maj 2016 \\
\hline
\end{tabular}




\begin{tabular}{|c|c|c|c|}
\hline Aktör & Namn & Befattning & Datum för intervju \\
\hline Kommunförbundet & Erja Lindberg & Utvecklingschef & 19 maj 2016 \\
\hline $\begin{array}{l}\text { NTM-centralen i Egentliga } \\
\text { Finland }\end{array}$ & Kimmo Puolitaival & Överdirektör & 6 juni 2016 \\
\hline $\begin{array}{l}\text { Norra Österbottens arbets- och } \\
\text { näringsbyrå }\end{array}$ & Maire Mäki & Direktör & 29 juni 2016 \\
\hline $\begin{array}{l}\text { Österbottens arbets- och } \\
\text { näringsbyrå }\end{array}$ & Juha Nummela & Servicechef & 29 juni 2016 \\
\hline \multicolumn{4}{|l|}{ Island } \\
\hline $\begin{array}{l}\text { VIRK (Arbetslivsrehabiliterings- } \\
\text { fonden) }\end{array}$ & Eysteinn Eyjólfssyni & PR- och kommunikationsansvarig & $\begin{array}{l}\text { Telefonintervju och } \\
\text { mejl konversationer } \\
23-25-\text { nov-15 }\end{array}$ \\
\hline Välfärdsministeriet & $\begin{array}{l}\text { Hanna Sigríður Gunn- } \\
\text { steinsdóttir }\end{array}$ & $\begin{array}{l}\text { Generaldirektör för Social- och } \\
\text { arbetsmarknadsdepartementet }\end{array}$ & 11-nov-15 \\
\hline $\begin{array}{l}\text { Icelandic Confederation of } \\
\text { Municipalities }\end{array}$ & Halldór Halldórsson & $\begin{array}{l}\text { Ledamot. Medlem i Reykjaviks } \\
\text { stadsfullmäktige. }\end{array}$ & $20-n o v-15$ \\
\hline Directorate of Labor & Gissur Pétursson & Direktör & 10-nov-15 \\
\hline VIRK & Pórarinn Pórsson & Konsult & $\begin{array}{l}\text { Telefonintervju och } \\
\text { mejl konversationer } \\
\text { 23-25-nov-15 }\end{array}$ \\
\hline University of Iceland & Guðný Eydal & Professor i socialt arbete & 13 maj 2016 \\
\hline Directorate of Labor & Gissur Pétursson & Direktör & 13 maj 2016 \\
\hline \multirow[t]{2}{*}{ Directorate of Labor } & Tryggvi Haraldsson & Specialist & 13 maj 2016 \\
\hline & Inga Rún Ólafsdóttir & $\begin{array}{l}\text { Director of Labor Relations at the } \\
\text { Organization of municipalities in } \\
\text { Iceland and Board Member of } \\
\text { Directorate of Labor }\end{array}$ & 13 maj 2016 \\
\hline $\begin{array}{l}\text { Statistics Iceland Labor Market, } \\
\text { Living Conditions and } \\
\text { Demography }\end{array}$ & Lárus Blöndal & Head of Unit & 13 maj 2016 \\
\hline Directorate of Labour & $\begin{array}{l}\text { Ragnheiður Her- } \\
\text { geirsdóttir }\end{array}$ & $\begin{array}{l}\text { Projektledare för sysselsättning } \\
\text { av personer med funktionsned- } \\
\text { sättning }\end{array}$ & 18 maj 2016 \\
\hline Directorate of Labour & $\begin{array}{l}\text { Guðlaug Hrönn } \\
\text { Pétursdóttir }\end{array}$ & $\begin{array}{l}\text { Chef för enheten för långtidsar- } \\
\text { betslösa }\end{array}$ & 18 maj 2016 \\
\hline Directorate of Labour & $\begin{array}{l}\text { Laufey } \\
\text { Gunnlaugsdóttir }\end{array}$ & Handläggare & 18 maj 2016 \\
\hline Directorate of Labour & Sveinn Sveinsson & Handläggare & 18 maj 2016 \\
\hline Reykjavík stad & Ragnhildur Ísaksdóttir & HR Manager & 19 maj 2016 \\
\hline Reykjavik stad & Auður Björgvinsdóttir & HR specialist & 19 maj 2016 \\
\hline
\end{tabular}




\begin{tabular}{|c|c|c|c|}
\hline Aktör & Namn & Befattning & Datum för ir \\
\hline \multicolumn{4}{|l|}{ Norge } \\
\hline Høyskolen i Oslo og Akershus & Tone Alm Andreassen & Professor & $11-n o v-15$ \\
\hline Frischcentret & Simen Markussen & Seniorforskare & 16 -sep-16 \\
\hline Institutt for samfunnsforskning & Ann-Helén Bay & Direktör & $13-n o v-15$ \\
\hline NAV Vest-Agder & Egil Lindekleiv & Seniorrådgivare & 29-okt-15 \\
\hline Arbeids- og sosialdepartementet & Ola Ribe & $\begin{array}{l}\text { Avdelningschef, Analyse- og inn- } \\
\text { tektspolitisk seksjon }\end{array}$ & $10-n o v-15$ \\
\hline NAV Vest-Agder & Martin Vestergård & Rådgivare & 29-okt-15 \\
\hline NAV Bergenhus & Erik Rasmussen & Enhetsleder & 9-maj-2016 \\
\hline NAV Eid & $\begin{array}{l}\text { Ingun Åland \& } \\
\text { Bodil Førde }\end{array}$ & Handläggare \& chef & 11-maj-2016 \\
\hline NAV Oppland & Jan Tore Stø & Avdelningsdirektör & 23-maj-2016 \\
\hline Arbeids- og velferdsetaten (NAV) & Yngvar Åsholt & Kunnskapsdirektør i NAV & 10-maj-2016 \\
\hline \multicolumn{4}{|l|}{ Sverige } \\
\hline $\begin{array}{l}\text { Institutet för arbetsmarknads- } \\
\text { och utbildningspolitisk utvärde- } \\
\text { ring, IFAU }\end{array}$ & Anders Forslund & Biträdande chef, professor & $25-$ nov-15 \\
\hline $\begin{array}{l}\text { Sveriges Kommuner och Lands- } \\
\text { ting (SKL) }\end{array}$ & Vivi Jacobson-Libietis & $\begin{array}{l}\text { Utredare, avdelningen för utbild- } \\
\text { ning och arbetsmarknad }\end{array}$ & $10-$ nov-15 \\
\hline Arbetsmarknadsdepartementet & Jonas Jarefors & Myndighetshandläggare & 28-jan-16 \\
\hline Arbetsmarknadsdepartementet & Mia Löw & Myndighetshandläggare & 28-jan-16 \\
\hline Arbetsförmedlingen & Clas Olsson & Biträdande generaldirektör & 9-dec-15 \\
\hline Arbetsförmedlingen & Mikael Sjöberg & Generaldirektör & 9-dec-15 \\
\hline $\begin{array}{l}\text { Stockholms universitet, } \\
\text { Institutionen för socialt arbete }\end{array}$ & Katarina Thorén & Universitetslektor & 9-nov-15 \\
\hline Arbetsförmedlingen & Mats Wadman & Analyschef & 20-nov-15 \\
\hline Arbetsförmedlingen & Cristofer Amlert & Kontorschef & 18-maj-16 \\
\hline Arbetsförmedlingen & Moa Hellerström & Handläggare & 18-maj-16 \\
\hline \multicolumn{4}{|l|}{ Grönland } \\
\hline Naalakkersuisut & Sanne Fandrup & Specialkonsulent & Juni 16 \\
\hline Kommunequarfik Sermersooq & Suni á Dalbø & Jobcenterleder & Juni 16 \\
\hline Piareersarfik Nuuk & Susanne Møller & Centerleder & Juni 16 \\
\hline Naalakkersuisut & Janus Kleist & Specialkonsulent & Juni 16 \\
\hline
\end{tabular}




\section{Aktör}

Namn

Befattning

Datum för intervju

Färöarna

Ministeriet for Arbejdsmarked og

Sørin P. Sørensen

Avdelningschef

Juni 16

Transport

ALS

Magni á Deild Olsen

Direktör

Juni 16

Tórshavn Universitet

Erika Anne Hayfield

Adjunkt i samhällsvetenskap

Juni 16

Socialministeriet

Henri Petersen

Avdelningschef

Juni 16

Åland

AMS

Tomas Lundberg

Myndighetschef

Juni 16

Landskapsregeringen, Närings-

livsavdelningen

Linnéa Johansson

Avdelningschef

Juni 16

Vårdö kom-

mun/Kommunförbundet

Magnus Sandberg

Direktör för Ålands kommunför-

bund, kommundirektör Vårdö

Juni 16 


\section{Litteratur}

\section{Danmark}

\section{Skriftliga källor}

Bredgaard, T. \& F. Larsen (2009). Regionale og lokale beskæftigelsesråd i spændingsfeltet mellem stat og kommune. Aalborgs Universitetsforlag.

Bredgaard, T. \& P. Kongshøj (red.), (2015). Dansk flexicurity: Fleksibilitet og sikkerhed på arbejdsmarkedet. Köpenhamn: Hans Reitzel.

Bredgaard, T., S. Rasmussen \& M.P Klindt (2015). Beskæftigelsessikkerhed. I Bredgaard, T. \& P. Kongshøj (red.). Dansk Flexicurity: flexibilitet og sikkerhed på arbejdsmarkedet. Köpenhamn: Hans Reitzels, s. 157-185.

Deloitte (2009). Evaluering af brugen af anden aktør under Service- og LVU-udbuddene.

Jørgensen, H. \& F. Larsen (2002). Labour market policies. I Jørgensen, H. (red.). Consensus, Cooperation and Conflict: The Policy Making Process in Denmark. Cheltenham: Edward Elgar.

Jørgensen, H. (2006). Arbejdsmarkedspolitikken fornyelse - innovation eller trussel mod dansk "Flexicurity". Bruxelles og Aalborg, LO \& FTF.

Larsen, F. et al. (2001). Kommunal aktivering: Hvordan implementeres store forventninger fra Christiansborg i de danske kommuner?. Tidsskrift for arbejdsliv. 4. årg., nr. 2.

Larsen, F. (2011). Ny beskæftigelsespolitik via administrative reformer? Tidsskrift for arbejdsliv. 13 årg., nr. 4 .

Pedersen, M. \& A. Hansen Meldgaard (2011). Konstruktionen af det selvstyrende jobcenter. Tidskrift for Arbejdsliv.

Madsen, P. et al. (2003). Drivkræfterne bag arbejdsmarkedspolitikken.

Torfing, J. (1999). Welfare with workfare: Recent reforms of the Danish welfare state. Journal of European Social Policy. 9, 1, s. 5-28.

Torfing, J. (2004). Det stille sporskifte i velfærdsstaten. Magtudredningen. Aarhus.

\section{Elektroniska källor}

Beskaeftigelsesministeriet. Den danske model. Tillgänglig:

http://bm.dk/da/Beskaeftigelsesomraadet/Arbejdsret/Det\%2oarbejdsretlige\%20omraade/De n\%2odanske\%2omodel.aspx. Hämtad: 2016-07-22.

Beskaeftigelsesministeriet. Ny ordning med seks ugers jobrettet uddannelse. 5 januari 2015. Tillgänglig:

http://bm.dk/da/Aktuelt/Nyheder/Arkiv/2015/01/Ny\%20ordning\%2omed\%2oseks\%2ougers\% 2ojobrettet\%2ouddannelse.aspx. Hämtad: 2016-07-21. 
Buhring, T. (2014). Denmark: New reform targets unemployment. EurWORK, European Observatory of Working Life. 17 december. Tillgänglig:

http://www.eurofound.europa.eu/observatories/eurwork/articles/labour-market-social-

policies/denmark-new-reform-targets-unemployment

Cabi. Vejledning og opkvalificering. Tillgänglig: http://www.cabiweb.dk/lovstof/vejledning-ogopkvalificering/. Hämtad: 2016-07-22.

Rigsrevisionen (2013). Beretning til Statsrevisorerne om effekten og kvaliteten af andre aktørers beskæftigelsesindsats. Tillgänglig: http://www.rigsrevisionen.dk/media/1943071/effekten-ogkvaliteten-af-andre-aktoerers-beskaeftigelsesindsats.pdf.

Steensberg, Morten (2015). Stigning ifleksjob: Men laver flere bare det samme?. 18 september 2015. Tillgänglig: http://www.avisen.dk/stigning-i-fleksjob-men-laver-flere-bare-detsamme_344842.aspx. Hämtad: 2016-07-21.

Styrelsen for Arbejdsmarked og Rekruttering (2015). Strategi for Styrelsen for Arbejdsmarked og Rekruttering 2015-2018. Tillgänglig: http://star.dk/upload/STAR/Files/Servicemenu/STARstrategi-2015.pdf.

Styrelsen for Arbejdsmarked og Rekruttering STAR Implementeringsguide 3.0. (juni 2016) http://star.dk/da/Om-STAR/Publikationer/2016/Implementeringsguide-version-3.aspx

Kommunernes Landsforening, Politisk partnerskab - styrning af beskæftigelseindsatsen, Tillgänglig: http://www.kl.dk/Kommunale-opgaver/Beskaftigelse/Kontanthjalp-ogstarthjalp/Politiske-partnerskab/

\section{Finland}

\section{Skriftliga källor}

Arbets- och näringsministeriet (2013). Työpolitiikan palvelurakennearviointi: Työpolitiikan palvelurakenteen ohjaus ja kolmikantayhteistyö. Valmisteluryhmän raportti TEM/1165/00.04.03/2013.

Arbets- och näringsministeriet (2014). Työpolitiikan palvelurakennearviointi: Työpolitiikan palvelurakenteen ohjaus ja kolmikantayhteistyö. Valmisteluryhmän raportti. TEM 28.10.2014.

Arnkil, R. \& Jokinen, E., Aho, S., Spangar, T. Syrjä, H. \& Karjalainen J. (2007). Muutosturva uudenlaisen yhteistyön airuena. Muutosturvan toimeenpanon ja toteutuksen arviointitutkimus. Työpoliittinen tutkimus 331. Helsinki: Työministeriö.

Arnkil, R., Karjalainen, V., Saikku,P., Spangar, T., Pitkänen, S. (2008). Kohti työelämälähtöisiä integroivia palveluja Työvoimatoimistojen ja työvoiman palvelukeskusten arviointitutkimus. Arbets- och näringsministeriets publikationer, Arbete och företagsamhet 18/2008.

Arnkil, R. \& Spangar, T. (2009). Working-life development based employment services - Is Finland heading for an alternative model? I Larsen, F. \& van Berkel, R. (red.) The New Governance and Implementation of Labour Market Policies. Copenhagen: Djoef Publishing.

European Commission (2014). Blended service delivery for jobseekers. Peer Review Host Country Paper. Brussels.

Julkisen työnvälityksen asema ja painopisteet. Valtiontalouden tarkastusviraston toiminnantarkastuskertomus. 174/2008. Helsinki 2008. 
Oosi (2012): Työvoimapolitiikan suunnittelu-, ohjaus- ja organisaatiomallin arviointi. Työpoliittinen aikakauskirja 2/2012.

Oosi, O. (2013). The Finnish Picture. Introductory paper. Working document: Owal Group Ltd and the Ministry of Employment and Economy.

Oosi, O. (2014). International Peer Review of Labour Policy Service Structures. Publication of the Ministry of Employment and the Economy, Employment and entrepreneurship, 56/2014.

Räisänen, H. (2014). Miten AN-toimiston työtarjous vaikuttaa työpaikkojen täytön ja rekrytoinnin kestoon? Työpoliittinen Aikakauskirja.1/2014.

Valtioneuvosto (2016). Työpolitiikan vaikuttavuus ja vaihtoehdot Tutkimus työpoliittisten toimenpiteiden toimivuudesta, tuloksista ja tulevaisuudesta (TYVA). Valtioneuvoston selvitysja tutkimustoiminnan julkaisusarja 3/2016.

\section{Elektroniska källor}

Aho, S. (2007). Basic income support and services for uninsured jobseekers: German and Finnish institutions and reforms compared. Comments and Statements. Tillgänglig: http://pdf.mutuallearning-employment.net/Downloads/Germany2007/Finland_DE_07.pdf

AN-palvelut. Yrkesinriktad arbetskraftsutbildning. Tillgänglig: http://www.tetjanster.fi/te/sv/arbetssokande/yrkesval_och_utbildning/arbetskraftsutbildning/index.html. Hämtad: 2016-07-21.

Arbets- och näringsministeriet (2014). Arbets- och näringsministeriets anvisning om arbets- och näringsbyråns uppgifter i genomförandet av systemet med utkomstskydd för arbetslösa. TEM/2192/03.01.04/2014. Tillgänglig: http://www.finlex.fi/data/normit/41984TEM2192Arbets_och_n_ringsministeriet458129003.pdf

Asplund, R., Kauhanen, A., Määttänen, N. \& Valkonen, T. (2015). Tuetaanko Suomessa työllistymistä vai työttömyyttä?. ETLA Muistio No 37. Tillgänglig: http://pub.etla.fi/ETLA-MuistioBrief-37.pdf

Folkpensionsanstalten. Nedsatt arbetsförmåga. Tillgänglig: http://www.kela.fi/web/sv/nedsattarbetsformaga. Hämtad: 2016-07-21.

Government Publications 12/2015. Finland, a land of solutions Strategic Programme of Prime Minister Juha Sipilä's Government. 29 May 2015. Tillgänglig:

http://valtioneuvosto.fi/documents/10184/1427398/Ratkaisujen+Suomi_EN_YHDISTETTY_net ti.pdf/8d2e1a66-e24a-4073-8303-ee3127fbfcac

Statsrådets kansli (2015). Lösningar för Finland Strategiskt program för statsminister Juha Sipiläs regering, 29.5.2015. Regeringens publikationsserie 11/2015. Tillgänglig: http://valtioneuvosto.fi/documents/10184/1427398/Ratkaisujen+Suomi_RUOTSI_YHDISTETT Y_netti.pdf/159cf517-d936-493c-8e47-b52912a8f824

Statens revisionsverk (2011). Sysselsättande av långtidsarbetslösa och förebyggande av marginalisering. Valtiontalouden tarkastusviraston. Tuloksellisuustarkastuskertomus 229/2011 Pitkäaikaistyöttömien työllistyminen ja syrjäytymisen ehkäisy. Tillgänglig: https://www.vtv.fi/files/2650/2292011_Pitkaaikaistyottomien_tyollistyminen_netti.PDF

Vaikeimmin työllistyvien työvoima- ja yrityspalvelujen järjestämisvastuun siirto valtiolta kunnille. http://www.kunnat.net/fi/asiantuntijapalvelut/aek/tyollisyys/eriavamielipide/Sivut/default.aspx 


\section{Juridiska källor}

RP 133/2012 rd. Regeringens proposition till riksdagen med förslag till lag om offentlig arbetskrafts- och företagsservice samt ändring av vissa lagar som har samband med den.

Lag om arbetsverksamhet i rehabiliteringssyfte 189/2001.

\section{Färöarna}

\section{Skriftliga källor}

Eythórsson, G.T., Mørkøre, J., Aradóttir, E \& Frederiksberg, R. (2004). Labour Market Service in the Nordic Periphery. A joint research project carried out by the University of Akureyri Research Institute and the University of the Faroe Islands. ANP 2004: 727. Nordic Council of Ministers.

Hayfield, E. A. \& Olavson, R. \& Patursson, L. (2016). Overview of the Self-Governing Areas and Their Labour Markets. I Part-Time Work in the Nordic Region III: An introductory study of the Faroe Islands, Greenland and Åland Islands. Nordic Council of Ministers Secretariat.

Knudsen, D. M., (2015). Rigsombudsmanden på Færøerne - Beretning 2015.

Sørensen, P. S. (2015). Landerapport for Færøerne.

\section{Grönland}

\section{Skriftliga källor}

Hayfield, E. A. \& Olavson, R. \& Patursson, L. (2016). Overview of the Self-Governing Areas and Their Labour Markets. I Part-Time Work in the Nordic Region III: An introductory study of the Faroe Islands, Greenland and Åland Islands. Nordic Council of Ministers Secretariat.

Naalakkersuisut (2006a). Landstingsforordning om offentlig hjælp. 20 november 2006.

Naalakkersuisut (2006b). Almindelige bemæerkninger til forordningsforslaget om offentlig hjælp. 4 augusti 2006. EM 2006/34.

Naalakkersuisut (2014a). Inatsisartutlov om arbejdsmarkedsydelse. 15 maj 2014.

Naalakkersuisut (2014b). Inatsisartutlov om arbejdsformidling m.v. 8 juni 2014.

Naalakkersuisut (2015a). Almindelige bemæerkninger til lovforslaget om førtidspension. 30 januari 2015. FM 2015/98.

Naalakkersuisut (2015b). Et trygt arbejdsmarked-Beskæftigelsesstrategi 2015. Departement for Erhverv, Arbejdsmarkeds og Handel.

Naalakkersuisut (2015C). Lovpligtig arbejdsmarkedsredegørelse 2014. Departement for Erhverv, Arbejdsmarked og Handel.

Naalakkersuisut (2015d). Vejledning om arbejdsmarkedsydelsen 2013. Departement for Erhverv, Arbejdsmarked og Handel. 
Naalakkersuisut (2015e). Inatsisartutlov om førtidspension. 9 december 2015.

Naalakkersuisut (2015f). Inatsisartutlov om job-, vejlednings- og opkvalificeringscentre. 9 december 2015 .

\section{Island}

\section{Skriftliga källor}

Maskína (2014). Vinnumálastofnun - Könnun meðal fyrrum bótapega.

\section{Elektroniska källor}

Europeiska kommissionen, Your social security rights in Iceland. Tillgänglig:

http://ec.europa.eu/employment_social/empl_portal/SSRinEU/Your\%20social\%2osecurity\%2 orights\%2oin\%2olceland_en.pdf. Hämtad: 2016-07-21.

Velferðarráðuneytið (2011). Nám er vinnandi vegur. 19 april 2011. Tillgänglig: https://www.velferdarraduneyti.is/frettir-vel/nr/32752

Velferðarráðuneytið (2015). Results of the Committee on the formulation of a proposal to labour market policy and organization of labour market matters in Iceland. Tillgänglig:

http://www.velferdarraduneyti.is/media/rit-og-skyrslur2015/Nidurstodur_vinnumarkadsmal_24062015.pdf

Vinnumálastofnunar (2014a). Árangur af vinnumarkaðsúrræđum Vinnumálastofnunar. 3 mars 2014. Tillgänglig: https://www.vinnumalastofnun.is/um-okkur/frettir/2014/03/arangur-afvinnumarkadsurraedum-vinnumalastofnunar

Vinnumálastofnunar (2014b). Ársskýrsla 2014. Tillgänglig:

https://www.vinnumalastofnun.is/media/1501/vmst-arsskyrsla-2014-vefur.pdf.

Vinnumálastofnunar (2015). Viljayfirlýsing um framtíðarskipan atvinnumála fatlađs fólks. 19 oktober 2015. Tillgänglig: https://www.vinnumalastofnun.is/um-

okkur/frettir/2015/10/viljayfirlysing-um-framtidarskipan-atvinnumala-fatlads-folks

\section{Juridiska källor}

Lag om arbetslöshetsförsäkring (2006/54)

Lag om arbetsmarknadsåtgärder (2006/55) 


\section{Norge}

\section{Skriftliga källor}

Andreassen, T.A., Legard, S. \& Lie, A. (2011). Forvaltningsenheter i NAV-Etableringsprosess og konsekvenser for oppgaveløsning. AFI-notat 5/2011, Arbeidsforskningsinstituttet.

Andreassen, T.A. \& Aars, J. (2015). Den store reformen - Da NAV ble til, Oslo: Universitetsforlaget. Arbeids- og sosialdepartement (2015). Tildelingsbrev til Arbeids- og velferdsdirektoratet. 23 mars 2015.

Arbeids- og sosialdepartementet (2016). Meld. St. 33 (2015-2016) Nav i en ny tid - for arbeid og aktivitet. Melding til Stortinget.

Asbjørn G., Mamelund S. \& Spjelkavik, Ø. (2015). Evaluering av forsøket Kjerneoppgaver i NAV. Delrapport 2. Arbeidsforskningsinstituttet.

Christensen, T. \& Lægreid, P. (2010). Reforming Norway's welfare administration. Statskontoret. Ekspertgruppen (2015). Et NAV med muligheter-Bedre brukermøter, større handlingsrom og tettere på arbeidsmarkedet.

Hansen H., Lundberg, K.G. \& Syltevik, L.J. (2013). Nav-med brukeren i sentrum? Oslo: Universitetsforlaget.

Larsen, H., Malmberg-Heimonen, I., Johannessen, A. (2012). Kunnskapsoppsummering om partnerskap mellom stat og kommune i NAV-kontorene. Rapport Høgskolen i Oslo og Akershus.

Mamelund, S. \& Widding, S. (2014). NAVs formidlings- og rekrutteringstjenester. AFI-rapport 14/2014.

Markussen, S. \& Røed, K. (2014). The impacts of vocational rehabilitation. IZA Discussion Paper No. 7892.

NAV (2012). Sosialtjenesteområdet i NAV. Presentation den 17 mars 2012.

NAV Vest-Agder (2015). Mål og disponeringsbrev for 2015 til alle enheter underlagt NAV VestAgder. 23 april 2015.

Riksrevisjonen (2014). Riksrevisjonens undersøkelse av NAV:s arbeidsrettede oppfølging av personer med nedsatt arbeidsevne. Dokument 3:10 (2013-2014).

\section{Elektroniska källor}

Arbeids- og sosialdepartementet (2015a). Arbeidsmarketstiltak. 23 september 2015. Tillgänglig: https://www.regjeringen.no/no/tema/arbeidsliv/arbeidsmarked-ogsysselsetting/innsikt/arbeidsmarkedstiltak/id86897/

Arbeids- og sosialdepartement (2015b). Den norske arbeidsmarknaden. 7 oktober 2015. Tillgänglig: https://www.regjeringen.no/no/tema/arbeidsliv/arbeidsmarked-ogsysselsetting/innsikt/den-norske-arbeidsmarknaden/id86893/

Arbeids- og sosialdepartement (2015c). Arbeidsmarkedspolitikken - institusjoner og organisering. 15 oktober 2015. Tillgänglig: https://www.regjeringen.no/no/tema/arbeidsliv/arbeidsmarkedog-sysselsetting/innsikt/den-norske-arbeidsmarknaden/institusjoner-ogorganisering/id570167/ 
Magne Lerø (2016). Anniken Hauglie som veiviser. Dagens Perspektiv. 23 maj. Tillgänglig: http://www.dagensperspektiv.no/2016/anniken-hauglie-som-veiviser

Mandal et al. (2015). Hvordan fungerer arbeidsavklaringspenger (AAP) som ytelse og ordning? Forskningsrapport, SINTEF. Tillgänglig: http://www.sintef.no/globalassets/sintef-teknologiog-samfunn/rapporter-sintef-ts/aap_rapport_sintef.pdf

NAV (2009). Arbeidsavklaringspenger (AAP). 2 november 2009. Tillgänglig: https://www.nav.no/no/Person/Arbeid/Sykmeldt\%2C+arbeidsavklaringspenger+og+yrkesskad e/Arbeidsavklaringspenger+\%28AAP\%29.217377.cms

NAV (2014a). Arbeidssøkere, antall og prosent - Avgang i løpet av 2014. Tillgänglig: https://www.nav.no/no/NAV+og+samfunn/Statistikk/Arbeidssokere+og+stillinger++statistikk/Tabeller/Arbeidss $\% \mathrm{C}_{3} \%$ B8kere $\% 2 \mathrm{C}+$ antall+og+prosent.+Tabell+1.+Avgang+fra+o ppf\% $\% \mathrm{C}_{3} \%$ B8lgingstiltak+eller+1\%C $3 \% \mathrm{~B} 8$ nnstilskudd $+\mathrm{i}+2014 \% 2 \mathrm{C} .423238 . \mathrm{cms}$

NAV (2014b). Årsmelding 2014. Tillgänglig:

http://www.nsd.uib.no/polsys/data/forvaltning/enhet/38611/aarsmelding

NAV (2015a). To styringslinjer. 9 juni 2015. Tillgänglig:

https://www.nav.no/no/NAV+og+samfunn/Om+NAV/Relatert+informasjon/To+styringslinjer.3 $56398 . \mathrm{cms}$

NAV (2015b). Sykepenger til arbeidstakere. 1 september 2015. Tillgänglig:

https://www.nav.no/no/Person/Arbeid/Sykmeldt,+arbeidsavklaringspenger+og+yrkesskade/S ykepenger/Sykepenger+til+arbeidstakere

NAV (2015C). Dagpenger når du er arbeidsledig. 18 september 2015. Tillgänglig: https://www.nav.no/no/Person/Arbeid/Dagpenger+ved+arbeidsloshet+og+permittering/Dagp enger $+\mathrm{n} \% \mathrm{C}_{3} \% \mathrm{~A}_{5} \mathrm{r}+\mathrm{du}+\mathrm{er}+$ arbeidsledig. $893 . \mathrm{cms}$

NAV (2015d). Økonomisk sosialhjelp. 4 november 2015. Tillgänglig:

https://www.nav.no/no/Person/Flere+tema/Sosiale+tjenester/\%C3\%g8konomisk+sosialhjelp.8 $7469 . \mathrm{cms}$

NAV. Tiltakför å komme i jobb. Tillgänglig:

https://www.nav.no/no/Person/Arbeid/Oppfolging+og+tiltak+for+a+komme+i+jobb/Tiltak+for +a+komme+i+jobb. Hämtad: 2016-07-21.

NHO (2014). NAV må endre praksis for dagpenger. Tillgänglig: https://www.nho.no/Politikk-oganalyse/Arbeidslivspolitikk/viktig-for-norsk-arbeidsliv/

Regjeringen (2013). Meld. St. 46 (2012-2013) Flere i arbeid, Arbeids-, og inkluderingsdepartementet. Tillgänglig: https://www.regjeringen.no/no/dokumenter/meld-st-46-

20122013/id733259/?ch=5

Revmatikeren (2008). Yrkesrettet attføring. 6 juli 2008. Tillgänglig: http://www.revmatiker.no/_attachment/4366?download=true

Salten regionråd (2011). SR-sak o8/11c: Uttalelse vedr. reduksjon av tiltaksplasser for yrkeshemmede med behov for arbeidsrettet bistand i skjermet sektor $i$ Nordland. Tillgänglig: http://www.salten.no/sites/s/salten.no/files/28606123a58cf1ddoc8fb4a98b86b372.pdf

SSB (2015). Kvartalsvis nasjonalregnskap, 4. kvartal 2014. Tillgänglig: http://www.ssb.no/nasjonalregnskap-og-konjunkturer/statistikker/knr/kvartal/2015-02-11

Ungt entreprenørskap Buskerud (2014). Årsmelding 2014. Tillgänglig:

http://www.ve.no/aarsmelding2014/Buskerud/Samarbeidspartnere/NAVARBEIDSLIVSSENTER

VOX (2015). Hvordan få innvandrere i jobb? 16 februari 2015. Tillgänglig:

http://www.vox.no/nyheter/Hvordan-fa-innvandrere-i-jobb/ 
Juridiska källor

LOV-2006-o6-16-20. Lov om arbeids-og velferdsforvaltningen [NAV-lagen].

\section{Sverige}

\section{Skriftliga källor}

Arbetsförmedlingen (2010). Jobb- och utvecklingsgarantin- en uppföljning ur deltagarnas perspektiv. URA 2010:2.

Arbetsförmedlingen (2015). Arbetsmarknadsrapport 2015.

Arbetsförmedlingen (2016). Arbetsförmedlingens arbetsgivarkontakter. Diarienummer: Af2016/0008 5651.

Bengtsson, M. \& Berglund, T. (2012). Den stora omvandlingen - Svensk arbetsmarknadspolitik under tre decennier. Arbetsmarknad \& Arbetsliv. 18:3.

Bengtsson, M. (2012). Transformation of Labour Market Policies in the Nordic Countries: Towards a regime shift in Sweden and Denmark? Conference paper ILERA World Congress 2012. Beyond Borders: Governance of Work in a Global Economy, 2-5 July 2012, Philadelphia, Pennsylvania.

Bennmarker, H., Grönqvist, E., Öckert, B., (2009). Betalt efter resultat - utvärdering av försöksverksamhet med privata arbetsförmedlingar. IFAU Rapport 2009:23.

de Luna X, Forslund A. \& Liljeberg L. (2008). Effekter av yrkesinriktad arbetsmarknadsutbildning för deltagare under perioden 2002-04. Rapport 2008:1.

Ernst \& Young (2009). Utvärdering av implementeringen av nya Arbetsförmedlingen. Slutrapport. Fransson, M. (2008). Självbeskrivning och tjänstekognition. Om processkartläggning på Arbetsförmedlingen. Karlstad University Studies 2008:23.

Harkman, A, Mikkonen, M och Okeke, S (2010). En utvärdering av kompletterande aktörer inom jobb- och utvecklingsgarantin, Working Paper 2010:2, Arbetsförmedlingen, Stockholm.

Karlsson,J., Szulkin, R., Lindblom, C. \& Bygren, M. (2014). Nya aktörer inom arbetsmarknadspolitiken: Hur väl lyckas de och till vilken kostnad? Institutet för Framtidsstudier. Forskningsrapport 2014/4.

Konkurrensverket (2013). Valfrihetssystem inom Arbetsförmedlingen. Rapport 2013:7.

Lundin, M (2011). Marknaden för arbetsmarknadspolitik: Om privata komplement till Arbetsförmedlingen. Rapport 2011:13, Institutet för Arbetsmarknads- och utbildningspolitisk utvärdering (IFAU), Uppsala.

Mörk, Eva (2011). Från försörjningsstöd till arbete - Hur kan vägen underlättas? IFAU Rapport 2011:6.

Nandorf, T. (2016). Arbetsförmedlingen: slå ihop lönestöden till ett. Dagens Nyheter. 22 februari.

Riksrevisionen (2009). Jobb- och utvecklingsgarantin - en garanti för jobb? Rapport till regeringen, Arbetsmarknadsdepartementet. Dnr: RiR 2009:22. Stockholm: Riksrevisionen.

Sjöberg, A-S. \& Mild Nygren, G. (2015). Omställningsavtal. Det extra stödet mellan jobb. TCO granskar. Nr. 3:2015.

Thorén, K. (2013). Arbetsmarknadspolitik i kommunerna. 2011/12:RFR15. 


\section{Elektroniska källor}

Arbetsförmedlingen (2013a). Rapport om fördjupad granskning av kompletterande aktörer. Tillgänglig:

http://www.arbetsformedlingen.se/download/18.3f8ebgad140aabd13a1f1f/1401114885212/Ra pport+om+f\% $\mathrm{C}_{3} \% \mathrm{~B} 6$ rdjupad+granskning+av+kompletterande+akt\% $\mathrm{C}_{3} \% \mathrm{~B} 6 \mathrm{rer}+\mathrm{version}+2 \mathrm{au}$ g.pdf

Arbetsförmedlingen (2013b). Sex år med kompletterande aktörer Arbetsförmedlingens erfarenheter och utmaningar. Tillgänglig:

http://www.arbetsformedlingen.se/download/18.1dba97a7142dc24a3c8eaa/1401114583431/R ap-

port_f\% $\%$ C3\%6rdjupad_granskning_av_kompletterande_akt\% $3 \%$ B 6 rer_f\% $\% \mathrm{C}_{3} \% \mathrm{~B} 6$ rkortad_v ersion_WEBB.pdf

Arbetsförmedlingen (2014). Arbetsförmedlingens Återrapportering 2014. Intern styrning och kontroll - planering och genomförda insatser. 19 maj 2015. Tillgänglig:

http://www.arbetsformedlingen.se/Om-oss/Var-

verksamhet/Rapporter/Aterrapportering/2014-05-19-Intern-styrning-och-kontroll---planeringoch-genomforda-insatser.html

Arbetsförmedlingen. Är du under 25 år?. Tillgänglig: http://www.arbetsformedlingen.se/Forarbetssokande/Stod-och-service/Fa-extra-stod/Ar-du-under-25-ar-.html. Hämtad: 2016-07-21.

Arbetsförmedlingen. Har du varit arbetslös länge?. Tillgänglig:

http://www.arbetsformedlingen.se/For-arbetssokande/Stod-och-service/Fa-extra-

stod/Arbetslos-lange.html. Hämtad: 2016-07-21.

Arbetsmarknadsdepartementet (2015). Regleringsbrev för budgetåret 2015 avseende Arbetsförmedlingen. Regeringsbeslut 2015-09-24. Tillgänglig: http://www.esv.se/Verktyg-stod/Statsliggaren/Regleringsbrev/?RBID $=16848$

Diedrich, A. \& Bergström, O. (2006). The Job Security Councils in Sweden. Göteborg University (IMIT) IMIT-report. Tillgänglig: http://www.imit.se/pdf/reports/2007_145.pdf

Försäkringskassan, Sjukpenning för arbetssökande. Tillgänglig:

https://www.forsakringskassan.se/privatpers/sjuk/arbetssokande/sjukpenning. Hämtad: 201607-21.

IFAU. Institutet för arbetsmarknads- och utbildningspolitisk utvärdering (2013) Jobb- och utvecklingsgarantin - Vilka deltar, vad gör de och vart leder det? Rapport 2013:12, IFAU, Uppsala. Tillgänglig via http://www.ifau.se/globalassets/pdf/se/2013/r-2013-12-jobb-ochutvecklingsgarantin.pdf.

SKL (2011). Kommunerna och arbetsmarknadspolitiken. En redogörelse för aktuell lagstiftning och samverkansformer. Tillgänglig:

http://skl.se/download/18.740caza014831128baa7fa4/1409742652410/Kommunerna+och+arb etsmarknadspolititken.pdf

Skoog, P. (2008). En ny myndighet formas. Arbetsförmedlingen. Tillgänglig:

http://www.arbetsformedlingen.se/download/18.59a3cc6a1218b235ea480002672/1401114621 432/nymyndighet.pdf

Statskontoret 2016:5 Analys av Arbetsförmedlingens interna styrning och utvecklingsarbete. www.statskontoret.se/publicerat/publikationer/2016/analys-av-arbetsformedlingens-internastyrning-och-utvecklingsarbete/ 


\section{Juridiska källor}

Arbetsmarknadsdepartementet (2014). Förtydliganden och förenklingar inom det arbetsmarknadspolitiska regelverket. Ds 2014:29.

Kommittédirektiv 2014:15. Översyn av Arbetsförmedlingen.

Regeringens proposition 2006/07:89. Ytterligare reformer inom arbetsmarknadspolitiken m.m.

Regeringens proposition 2015/16:1. Budgetpropositionen för 2016. Förslag till statens budget för 2016, finansplan och skattefrågor.

Regeringens skrivelse 2014/15:42. Riksrevisionens rapport om Arbetsförmedlingens arbete vid varsel m.m.

Regleringsbrev: A2007/6711/A

SOU 2015:44. Arbetslöshet och ekonomiskt bistånd. Betänkande av Utredningen om stöd och krav avseende arbetslösa personer som tar emot ekonomiskt bistånd.

\section{Åland}

\section{Skriftliga källor}

Ams (2011). Intern uppföljning av Katapult och Ung resurs 2002-2011.

Lund, L. (2008). Ekonomiska levnadsvillkor för funktionshindrade personer på Åland. Ålands landskapsregering.

ÅSUB (2015). Ekonomisk utsatthet och social trygghet. Rapport 2015:2.

\section{Elektroniska källor}

Ams. Arbetslöshetsersättning. 24 mars 2014. Tillgänglig:

http://www.ams.ax/arbetssokande/arbetsloshetsersattning/arbetsloshetsersattning. Hämtad: 2016-07-22.

Ams. Arbetsmarknadsprojekt: Emmaus returcafé. Tillgänglig:

http://www.ams.ax/arbetssokande/arbetsmarknadsprojekt. Hämtad: 2016-07-22.

\section{Juridiska källor}

ÅFS 2003:71. LL om tillämpning i landskapet Åland av lagen om utkomstskydd för arbetslösa.

ÅFS 2006:9. LL om Ålands arbetsmarknads- och studieservicemyndighet.

ÅFS 2006:8. LL om arbetsmarknadspolitisk verksamhet. 


\section{Övriga}

Finn, D. (2011). Subcontracting in Public Employment Services: Review of research findings and literature on recent trends and business models. The European Commission Mutual Learning Programme for Public Employment Services. GHK Limited / Budapest Institute, DG Employment, Social Affairs and Inclusion, Brussels.

Dubois, Hans, Georgiana Runceanu och Robert Anderson (2016)," Extending working lives through flexible retirement schemes: Partial Retirement", Eurofound, Luxembourg: Publication Office of the European Union

HoPES (2013). Final report: PES Efficiency Working Group.

Martin, J.P. (2014). Activation and Active Labour Market Policies in OECD Countries: Stylized Facts and Evidence on their Effectiveness. IZA Policy Paper. No. 84. Tillgänglig:

http://ftp.iza.org/pp84.pdf

Mosley, H. (2011). Decentralisation of public employment services. Analytical Paper.

Mosley, H. (2012). Accountability in Decentralised Employment Service Regimes. OECD Local Economic and Employment Development (LEED) Working Papers. 2012/10.

Nordiska ministerrådet (2014). The Nordic model - challenged but capable of reform. TemaNord 2014:531.

Nordiska ministerrådet (2015). Arbetsmarknadsutbildning i Norden - studie om de nordiska systemen för arbetsmarknadsutbildning för arbetslösa. TemaNord 2015:31.

Nordiska ministerrådet (2016). Utvärdering av Nordjobb - Nordens arbetsutbytesprogram för unga. TemaNord 2016:522.

Nunn, A. (2012). Performance management in Public Employment Services. European Commission. Brussels.

OECD (2015). Employment Outlook 2015. Tillgänglig: http://www.oecd.org/els/employmentoutlook-previouseditions.htm.

PARES (2012). Local and regional partnerships: Recommendations to employment services. Tillgänglig: http://ec.europa.eu/social/main.jsp?catld=991\&langld=en\&moreDocuments=yes

PARES (2015). Effective E-Services: Recommendations to Employment Services. 17 mars 2015.

Weishaupt, Timo, J. (2014). Central Steering and Local Autonomy in Public Employment Services. Analytical paper, October 2014 PES to PES Dialogue. The European Commission Mutual Learning Programme for Public Employment Services. European Commission, Brussels. Tillgänglig:

http://ec.europa.eu/social/keyDocuments.jsp?advSearchKey=pesautonomy\&mode=advanced Submit\&langld $=$ en $\&$ policyArea $=\&$ type $=0 \&$ country $=0 \& y e a r=0$

Wennemo, Lanninger och Sundström (2014). Part-time work in the Nordic region. Part-time work, gender and economic distribution in the Nordic countries. Nordiska Ministerrådet. TemaNord 2014:503. 



\section{Summary}

The purpose of this study is to investigate whether the organisation and steering mechanisms have an impact on labour market policy outcomes. Does model A reach its objectives better as compared to model B? Does a measure or a reform within system A yield different results and effects compared to a measure or a reform in system B?

In order to convey an accurate picture of labour market policy in the Nordic countries, the data collection was carried out country by country by an inter-Nordic team including command of all Nordic languages. A total of some seventy interviews were conducted in the five countries and the three autonomous regions during the course of the research done for this report. All interviewees are listed in the bibliography in chapter 10. In addition to the interviews, a wide range of documents, evaluations and reports from each country was taken into account and analysed. Also relevant chapters of national legislation of each country were examined in order to discern similarities and differences in the diverse systems.

This report employs the terms active and passive labour market policy measures. The same terminology is also used by the OECD as well as many other organisations. Passive measures imply different types of allowances and reimbursements that the unemployed may be entitled to, such as unemployment benefit. The unemployment benefit is often conditional to the unemployed showing activity in some way, for instance through looking for work. ${ }^{177}$ Active measures, meanwhile, generally comprise arrangements matching demand and supply. Within these schemes, the employment service sees to the effective and efficient matching of vacancies and jobseekers, in addition to which there are also different types of internships and labour market training schemes arranged on the supply side, while measures such as pay subsidies are directed at the demand side. ${ }^{178}$

In international contexts there are often mentions of the Nordic Model - a model that unites the Nordic countries and their welfare systems along one coherent policy line. The Nordic countries do indeed have much in common, such as comparatively strong public sectors, family policy and an ambitious welfare system largely financed

\footnotetext{
${ }^{177}$ Den stora omvandlingen - Svensk arbetsmarknadspolitik under tre decennier, Arbetsmarknad \& Arbetsliv, årg 18, nr 3, hösten 2012

${ }^{178}$ Ibid.
} 
by taxes. Another largely shared characteristic of the Nordic countries is a labour market that is regulated by agreements and strongly influenced by the social partners, and where the public sector strives for economic growth, a high employment rate and policies for equality and equity. There is therefore a solid basis for mutual learning among the countries, to which process this report hopefully may contribute.

\section{The organisation of labour market policies}

There is a clearly discernible dominant policy line among the Nordic countries in labour market questions. The main line is a hierarchical structure where the primary responsibility for the labour market system and policy lies with the Ministry of Employment and where the Minister for Employment holds the final responsibility for the forming of the labour market policy.

\section{Steering Instruments}

Legislation is an important steering instrument in all countries regulating many parts of the labour market and its functions. It is nevertheless used to a greater extent in policy making in Finland, Iceland and Sweden as compared to Denmark and Norway.

Economic incentives play the most prominent role in the Danish labour market policy, where an incentive system (refusionsordning) is a central mean for the state to control the labour market measures of municipalities. The use of economic incentives involves a risk of excessive focus being directed at getting the greatest possible amount of money back (as in Denmark), or at reducing expenses (as in Finland, Iceland and Sweden). When attention is thus focused on expenses, there is a risk of decisions being made in a short-sighted vein in order to maximise gains (or minimise losses). In practice, this may entail efforts being directed at the unemployed closer to the labour market rather than those most alienated from it.

The labour market partners are strongly included in the Nordic labour market model. In Denmark, Finland and Sweden, the labour market partners are involved for instance through the unemployment insurance funds being linked to trade unions. On Iceland, all questions related to the labour market are considered through tripartite arrangements. In Norway, the labour market partners have informal influence and participate actively through correspondence, consultations and in other ways. 
Figur 2: Monitoring systems in the Nordic countries
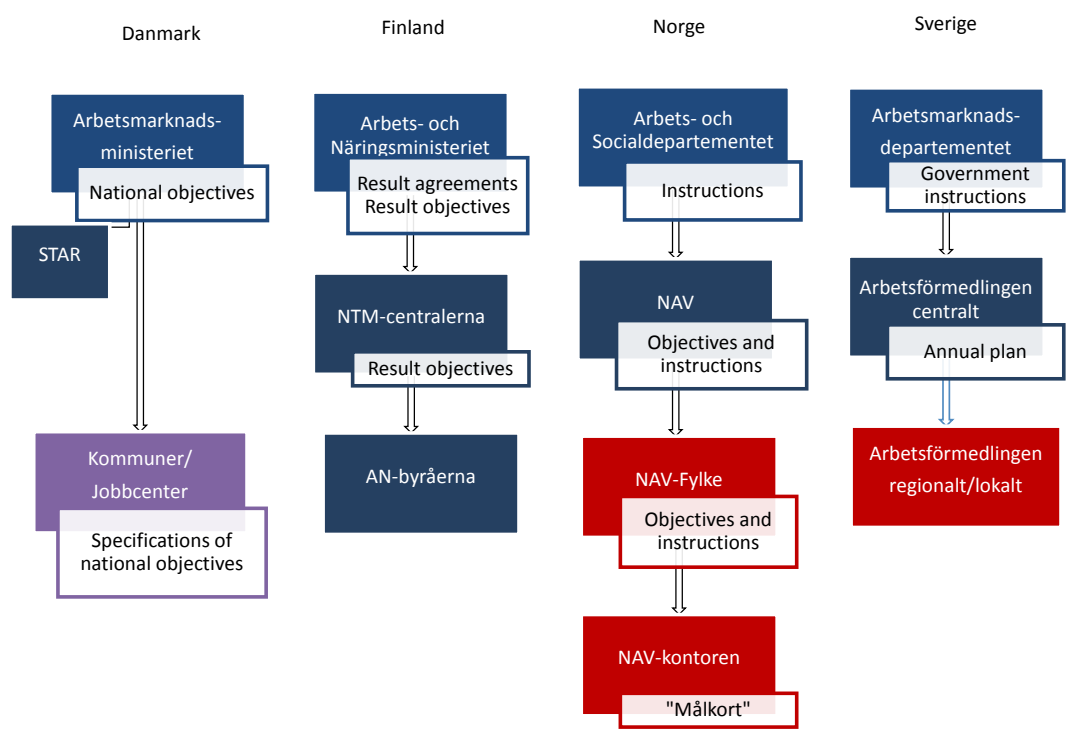

Kommunerna

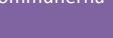

\section{Centralisation and decentralisation}

The degree of centralisation/decentralisation has in the Nordic countries fluctuated along with various reforms that have influenced the relation between local autonomy and centralised government. This study has observed the importance of the right balance between local and centralised authority: on the one hand, the municipalities must be strong enough to fulfil local needs, whereas on the other hand citizens in the entire country must be treated equally and justly, all the while measures should also be effective and efficient.

Along with the structural reform in Denmark in 2007 the national employment service was shut down and its tasks transferred to municipalities and to the newly established job centres. In Finland, a 2013 reform aimed at securing a well-functioning labour market involved a merger of the then 74 local labour market offices into the 15 regional public employment and business offices (TE Offices). 
The NAV reform in Norway in 2005-2006 entailed a merger of the national labour market authority and the social insurance authority into a joint national authority. This authority is also integrated into the local level through municipal social services, as secured by law and by agreements. All these responsibilities were collected and covered by the new authority NAV. The actual job mediation that the NAV offices do is arranged through an equal partnership between the state and the municipalities. Municipalities thus got a role in a larger, more comprehensive organisation of the labour market policies. This model of coordination of the national and municipal portfolios on the local level is rather unique.

A common characteristic concerning the role of the municipalities in the Nordic countries is that despite there not always being formal requirements for the municipalities to implement active labour market measures, they nevertheless frequently take such initiatives at their own discretion. This is because the municipalities are often responsible for their unemployed inhabitants or for a particular group among the unemployed, such as the long-term unemployed, and may for instance be in charge of paying income support to them. Steering at the state level has increased those kind of costs for passive labour market measures at the municipal level in Finland, Iceland and Sweden. Seeking to reduce these costs, municipalities in these countries have become more involved in the activation of the unemployed.

\section{The Faroe Islands, Greenland and Åland}

On the Faroe Islands, a unique scheme unlike any other in the Nordic countries and regions has been chosen to direct the labour market policy. Here, the Faroe organisation ALS is the sole responsible organisation for activation measures, such as job mediation, labour market training, counselling etc., as well as for the unemployment insurance. The unique trait is that the ALS is wholly independent from the general state apparatus. There have been no fundamental changes in the Islands' labour market policy since 1992, when the Act on the ALS passed in Parliament. However, activation is increasingly used as a mean to reduce unemployment and to make the labour force more mobile, especially since the latest change in legislation in 2013.

On Greenland, the autonomous government (Naalakkersuisut) holds the formal superior responsibility for labour market policy through its Ministry of Industry, Labour and Trade. The Ministry formulates the labour market policy and enforces a large part of the employment measures. Apart from the Ministry, the four municipalities of Greenland also have a responsibility for the implementation of labour market policy. The most important recent reform on Greenland was carried out during 2016. It in- 
volves a merger of the municipal labour market offices and the so called jobcentres. The legislative change entails that the unemployed will now have joint access to counselling, to further education and to the drafting of a personalised action plan.

On Åland, the labour market policy is strongly influenced by the labour market and study service authority of Åland (AMS). Formal superior responsibility lies with the autonomous government, which assumes an annual activity strategy with a focus on labour market policy in the region. The strategy proposal, however, is drawn up by the AMS. There have been no significant reforms in the labour market policy on Åland in the past ten years.

\section{Motives for reforms}

In Sweden and to a certain extent also in Denmark, reforms have resulted from politically motivated decisions, often following a change of government, although the reforms in Denmark have been driven by a broad majority in Folketinget. In Finland and Iceland, reforms have been urged by external circumstances, such as the financial crisis in Iceland entailing a strong increase in unemployment, or the weak economic growth in Finland permitting fewer resources for labour market policy.

A focus on activation policies, or "work-first principle", has in all the countries concerned been recognised as a fundamental precondition for increasing labour market participation and thus for maintaining or improving national welfare. Several countries have also made efforts to reduce sickness-related absences and put increased emphasis on rehabilitation. Another recurrent motive for organisational reforms in many of the countries has been a defective distribution of responsibilities, where the different actors and authorities have too often tended to perceive an individual as "someone else's responsibility". Such problems seem particularly common in the task distribution between the state and the municipalities. Reforms implemented in steering and organisation in the Nordic countries in the past decade have often carried traits of New Public Management. Digitalisation has also to some extent contributed to the development of the labour market services in the countries. 


\section{Summary of conclusions}

\section{Steering and organisation on the central level}

An investigation of the reforms executed under the past decade indicates that the steering and organisation of the labour market policy are subject to nearly constant changes. In Finland for instance, there have been recurrent adjustments in the distribution of responsibilities, in the roles of the different actors, and in the supply of services. At the other end of the scale, Iceland has had relatively few alterations in its system. The general reform trend in the Nordics has been increasing centralisation of the steering, albeit with a maintained or enhanced local mandate.

Organisational mergers rarely yield the expected results, at least in the short or medium term. Many examples of this fact can be given concerning the Nordic countries, such as for instance the new Ministry of Economic Affairs and Employment in Finland or the NAV in Norway. The NAV had a long opening phase during which fewer unemployed found work than before the reform. Mergers and organisational changes should therefore be used cautiously. Yet on the other hand, the establishment of NAV has to a great extent repaired the common Nordic problem of individuals falling outside of everyone's responsibility and being sent from one authority to the other. Mergers of different authorities may contribute to facilitating people's lives through onestop-shops, which seem to have the most significant impact for those alienated from the labour market. This group is also prioritised target groups in all the countries concerned. The Norwegian example may therefore well be used as inspiration for other countries.

Despite the frequent reforms in the Nordics, the fundamental steering of the labour market policy has remained largely unchanged. The main focus has been on the supply side (that is, on the jobseekers and their ability and incentives to work), while the demand side (employers, business and the will to employ) has been of secondary importance. Finland stands out in this regard however, as labour market policy and business policy have been linked together, both through mergers on the ministerial level and through the strengthened role played by the Centres of Economic Development, Transport and Environment (ELY Centres).

In Denmark, Norway and Sweden, the endeavour for a strongly controlled policy initially led to the implementation of a strictly goal-oriented steering. In recent years, however, the steering mechanisms have in all three countries been found to be much too rigid. The steering has to a too high degree ended up focusing on fulfilling detailed, measure specific objectives. This makes it difficult to adjust policies to local 
conditions and individual needs, such as is necessary for labour market policy to be efficient.

In the countries that have shifted towards a more evidence based policy, there are as of yet few or no evaluations of the new policies. Preliminary indications nevertheless suggest that evidence based policy - including for instance professionalised counselling of clients - works well. According to studies that have already been carried out, and as also confirmed during our interviews, it is valuable for and appreciated by the individual job mediator that tried and true measures and provisions are available, as long as the job mediator her/himself is allowed to judge whether the measure should be used or not.

Economic incentives as aspects of the steering were implemented in the Nordic countries during the period examined, in their purest form in Denmark.

Economic incentives with a direct or indirect impact on municipal expenses have expanded the role the municipalities play in the activation of the unemployed. Economic incentives are used for the purpose of reducing unemployment, but since such incentives have entailed increased expenses for the municipalities in Finland, Iceland Sweden, it has become necessary for the municipalities to become active labour market policy actors, if they have not been so previously.

Incentive structures may lead to undesired distortions in target groups. Even very detailed follow-up evaluations, with indicators defined separately for each target group etc., may have distortive effects, even when no economic incentives are connected to the steering.

In all the Nordic countries, private actors have been to some extent involved in the implementation of the labour market policy. It is however difficult to draw general conclusions concerning procurement of services as such, as the execution of the procurement process actually seems to be of greater importance than the procurement itself. Whether the systems and the job-seeking individuals benefit from a greater number of private actors does therefore not depend on whether or not there are private alternatives, but on the ability of the public employment services to procure, steer and evaluate the private actors.

\section{Decentralisation and the role of the municipalities}

Research shows that clear structures of steering and clear roles, with a wellfunctioning steering chain all the way from the ministries to the implementing actors, are important for the effective implementation of labour market policy.

Effect evaluations of reforms made in the Nordic countries indicate that it takes a long time after a reform is implemented before such a clear steering chain emerges. 
This fact was also confirmed in the interviews conducted for this study with representatives of the different levels of the steering chain.

Choices made between a steering emphasising adjustments to local and individual circumstances on the one hand, and a more centralised and uniform steering on the other, might potentially have different effects on different groups of the unemployed. Individuals who are more alienated from the labour market, as well as small and local employers, often benefit from a system that allows for greater degree of local adaptation. ${ }^{179}$ Interviews conducted with representatives of the local level seem to support the idea of a certain level of autonomy being necessary for an individualised provision of services. This is also the outlook adopted in most of the countries in question.

The municipality has become a more important actor as there are some unemployed who for various reasons no longer are entitled to unemployment benefit or activity allowance and instead apply for social assistance. Municipalities have also been included in a more deliberate and active manner in most countries. This development has had two separate objectives: first, to link active and passive measures together, and second, to allow for more integrated services to be provided for individuals who are alienated from the labour market and who may be in need of social services in addition to the services of public employment services.

The municipalities also have strong incentives to engage social assistance recipients on the labour market. ${ }^{180}$ It is therefore better to incorporate the municipalities into the national labour market policy (Denmark, Norway and partly Finland) rather than creating parallel systems (Sweden, partly Finland) where there is a risk of municipalities seeking to mainly reduce costs rather reducing unemployment, and where the measures introduced are not designed in the most efficient possible way. ${ }^{181}$

\section{Recommendations: What can the countries learn from one another?}

Regardless of, or thanks to, all the differences between the courses chosen in the different Nordic countries, there are good opportunities for the countries to seek inspiration from one another for the development of their labour market policies.

\footnotetext{
${ }^{179}$ Työpolitiikan palvelurakennearviointi: Työpolitiikan palvelurakenteen ohjaus ja kolmikantayteistyö. Valmisteluryhmän raportti. TEM 28.10.2014. s. 17-18.

${ }^{180}$ Se bl.a Martin, J.P. (2014) Activation and Active Labour Market Policies in OECD Countries: Stylized Facts and Evidence on their Effectiveness. IZA Policy Paper No. 84.

${ }^{181}$ Och ofta inte heller ett sätt som är meningsfullt för deltagarna. Intervju med Katarina Thorén som forskat om kommunala arbetsmarknadsåtgärder.
} 
- Initiate an institutionalised cooperation at the Nordic level between national public authorities responsible for the implementation of labour market policy. This is motivated partly by the potential for mutual learning and partly by the fact that the Nordic countries have a well-functioning common labour market that would benefit from stronger cooperation those working with public employment services.

- Reforms in the Nordic countries have overall been frequent. The interviews conducted along the steering chain reveal that it has sometimes been difficult for the employees to keep track of the changes. There has been a particularly great interest for different types of organisational mergers, which have occurred in some form in each country. Mergers may of course have both positive and negative effects, as has been proven by various evaluations. Positive effects may follow when mergers bring passive and active labour market policies closer together, when one-stop-shop solutions are found, and when individuals are secured against falling outside of everyone's responsibility. There are good examples of such solutions available in the Nordic countries. Decision-makers must be aware that transition periods may be long, and before the new organisations start running smoothly results may be worse than prior to the reform. The duration of such transition periods are easily underestimated.

- A pendulum swing can be observed from detailed/activity steering to more restricted objective/result steering over time in the Nordic countries. In the midoos, the pendulum had swung far into the field of detailed steering virtually across the Nordics. Since then, the pendulum has moved towards greater local autonomy and a greater trust in the local level expertise of the relevant authorities. Evaluations unanimously indicate the positive effects of increased local autonomy and of greater use of objective steering instead of activity steering. The effect is particularly positive concerning those most alienated from the labour market. Ministries and other actors high up in the steering chain should therefore be careful when proposing new steering signals.

- The use of economic incentives between actors in the system, as well as to rigid follow-up requirements on the level of activities give rise to undesired distortive effects. This often happens in the form of prioritisation of a certain target group at the expense of some other group. It would seem that clear labour policy objectives, set by target group, constitute a sufficient steering signal ensuring prioritisation of different target groups in a desired manner. 
- The effectiveness and efficiency of using private actors largely depends on the systems that the procuring authority has in place for procurement, control, observation, follow-up and evaluation. This could be a first step towards a more institutionalised cooperation between the public employment services in the Nordic countries, where knowledge and experiences about private actors completing public services could be shared and expanded. At least in Denmark, Finland and Sweden, the legal frameworks concerning such procurements are very similar. In the longer term, a Nordic market for employment measures could be built up, resulting in more professionalised actors both in the public and in the private sector.

- The role of the municipalities in labour market policy has grown as "the labour line" has tightened the conditions on which the unemployed may receive stateadministered benefits and a greater number of unemployed are consequently directed to reimbursement systems administered by municipalities, such as to social assistance. As a consequence, municipalities across the Nordic countries have introduced their own labour policy measures. The risk with this development is that it may give rise to the creation of parallel systems involving relatively ineffective and inefficient measures, especially in countries where there is less cooperation between municipalities and public employment services, such as was previously the case with Sweden. It is therefore of central importance that the national public employment services have a tight and dynamic cooperation with municipalities, and that the municipalities can influence the labour market measures introduced within their borders. 


\section{Bilaga 1: Arbetsmarknads-politikens verktygslåda}

Som beskrivits i kapitel två visar statistiken att det bland de nordiska länderna går att urskilja två olika mönster gällande den offentliga arbetsmarknadspolitiken. Norge och Sverige har inom ramen för den statliga arbetsmarknadspolitiken framförallt satsat på aktiva arbetsmarknadsåtgärder, medan Danmark och Finland haft större kostnader för de passiva åtgärderna. Generellt för hela Norden kan sägas att utgifterna som del av BNP på passiva arbetsmarknadsåtgärder har sjunkit sedan 1990-talet, med undantag för en period i början av 2000-talet som ett resultat av den då stigande arbetslösheten. Nedan beskrivs den aktiva respektive passiva arbetsmarknadspolitikens verktygslåda mer ingående för respektive land samt för de autonoma regionerna Grönland, Färöarna och Åland.

\section{Aktiv arbetsmarknadspolitik}

\section{Förmedling}

Förmedling av arbete, inklusive tjänster som vägledning, information och kortare kurser i att skriva CV eller jobbansökningar, är en grundläggande arbetsmarknadsåtgärd som erbjuds arbetslösa i någon utsträckning i samtliga nordiska länder och autonoma regioner.

Danmark utmärker sig från de övriga nordiska länderna i att förmedlingstjänster inte erbjuds samtliga jobbsökande. Vem som får ta del av tjänsten avgörs av en bedömning som görs av kommunernas jobbcenter. Dessa bedömer om arbetslösa och personer som genomgår rehabilitering är antingen arbetsföra eller aktivitetsföra. De som bedöms kunna komma i arbete inom en kort period klassas som arbetsföra, och får därmed begränsat stöd med jobbsökande, men kan bli anvisade så kallade nyttejob: enklare arbeten som den arbetsföra är tvungen att ta som arbetslös för att fortsatt erhålla arbetslöshetsersättning. De som däremot bedöms ha svårt att komma i arbete inom en snar framtid, av olika skäl bedöms vara aktivitetsföra. Dessa ska stå till förfogande för rimliga arbetserbjudanden från jobbcentret. 
I de övriga nordiska länderna erbjuds databaser med lediga tjänster, och i varierande utsträckning olika former av förmedlingsstöd såsom coachning och träning i att söka jobb. I Norge erbjuder NAV till exempel så kallad avklaring, som riktar sig till dem som är osäkra på vad de kan jobba med exempelvis på grund av dålig hälsa eller en längre tids arbetslöshet. Genom avklaring kan arbetssökande få stöd genom till exempel test av arbetsförmåga. ${ }^{182}$ Det är relativt vanligt att denna åtgärd upphandlas av extern aktör.

I de autonoma regionerna sker förmedlingen av arbeten på liknande sätt som i de nordiska länderna. På Grönland är det dock endast kommunen Sermersooq som har ett jobbcenter där mellan 10-12 heltidstjänster finns. För att nå ut med arbetsförmedlingen jobbar man utåtriktat mot de tre andra storkommunerna, Kujalleq, Qaasuitsup och Qeqqata, med "flygande" personal. Uppdraget är brett med hantering av sociala förmåner, arbetsförmedling och handlingsplaner för arbetslösa. På Färöarna är det ALS som har huvudansvaret för alla sysselskapande åtgärder och sköter arbetsförmedlingen genom sitt kontor i Tórshavn. På Åland är det AMS (arbetsmarknads- och studieservicemyndighet) som sköter arbetsförmedlingen och de har ett kontor i Mariehamn. Kommunernas roll är att ta emot arbetssökande i olika former av arbetsträning, praktik och subventionerad anställning, men de har ingen formell (lagstadgad) roll i systemet.

\section{Arbetsmarknadsutbildning}

Arbetssökande i de nordiska länderna erbjuds även olika arbetsmarknadsutbildningar med syfte att deltagarna ska tillgodogöra sig kompetenser för att komma in på arbetsmarknaden. Arbetsmarknadsutbildningarna kan bestå av kortare arbetsmarknadskurser, yrkesutbildning eller deltagande i reguljär utbildning.

Arbetsmarknadsutbildningen är i Finland, Norge och Sverige organiserad i en struktur där staten står för finansiering och utformning. Utbildningarna upphandlas sedan från privata och offentliga aktörer. I Danmark och på Island är däremot systemen för arbetsmarknadsutbildning mer decentraliserade. På Island sker kurserna i samarbete med det reguljära utbildningssystemet, vuxenutbildningssystemet och privata leverantörer, och arbetssökande deltar oftast i reguljära kurser och erhåller ersättning för avgiften. I Danmark betalar jobbcentren kursavgifter för de arbetslösa till reguljära utbildningsinstitutioner, som inte har någon särskild inriktning mot ar-

\footnotetext{
${ }^{182}$ NAV. Tiltak för å komme i jobb. Tillgänglig:

https://www.nav.no/no/Person/Arbeid/Oppfolging+og+tiltak+for+a+komme+i+jobb/Tiltak+for+a+komme+i+jobb Hämtad: 2016-07-21.
} 
betslösa, men som i många fall ligger inom arbetsmarknadsutbildningarna (AMU) som i Danmark ges till långt fler än de arbetslösa. ${ }^{183}$

Vad gäller arbetsmarknadsutbildningarnas innehåll är de danska AMU till stor del praktiskt inriktade och syftar till att ge deltagarna kompetenser för framtida yrken. Från och med den 1 januari 2015 finns även möjlighet för försäkrade arbetslösa att delta i sex veckors arbetsmarknadsutbildning. De kurser som ingår i åtgärden framgår av en nationell lista som är framtagen av Arbetsmarknadsdepartementet (Beskaeftigelsesministeriet). ${ }^{184}$

Även de finska arbetsmarknadsutbildningarna har ett huvudsakligen praktiskt fokus, i form av yrkesutbildningar som ofta leder till certifiering av olika slag. I Finland erbjuds bland annat karriärträning för företagande, som kan kombineras med att starta eget företag. ${ }^{185}$

Den isländska arbetsförmedlingen erbjuder olika kurser och workshops i exempelvis personlig utveckling, arbetssökande och grundläggande datakunskap för arbetslösa, i flera fall i samarbete med utbildningsinstitut och lärosäten. Även längre, yrkesinriktade kurser av mer praktisk karaktär erbjuds.

I Norge finns en rad olika arbetsmarknadsutbildningar för dem som behöver stöd för att kunna konkurrera på arbetsmarknaden. Oftast består utbildningen i korta arbetsmarknadskurser (AMO-kurser), som är yrkesinriktade kurser i NAV:s regi, ofta med en kombination av praktisk och teoretisk utbildning. Företag kan även få bidrag för att erbjuda anställda interna utbildningar inför större omställningar. Det finns även ett program vid namn Kvalificeringsprogrammet, som syftar till att erbjuda arbetsträning till personer som bedöms ha svag arbetsförmåga, och där alternativet är att få försörjningsstöd. Till skillnad från de andra utbildningsåtgärderna finansieras detta program av kommunerna. ${ }^{186}$

Den svenska arbetsmarknadsutbildningen (AUB) har ett starkt praktiskt fokus och är ofta inriktad mot bristyrken, i första hand arbetaryrken. Deltagare som bedöms behöva kvalificera sig ytterligare för att ta del av en AUB-utbildning kan bli anvisad en så kallad förberedande utbildning (FUB).

\footnotetext{
${ }^{183}$ Nordiska ministerrådet (2015). Arbetsmarknadsutbildning i Norden - studie om de nordiska systemen för arbetsmarknadsutbildning för arbetslösa. 2015:31.

${ }^{184}$ Beskaeftigelsesministeriet. Ny ordning med seks ugers jobrettet uddannelse. 5 januari 2015. Tillgänglig:

http://bm.dk/da/Aktuelt/Nyheder/Arkiv/2015/01/Ny\%2oordning\%2omed\%2oseks\%2ougers\%2ojobrettet\%2ouddannelse.a spx Hämtad: 2016-07-21.

${ }^{185}$ AN-tjänster, Utbilda dig till företagare. Tillgänglig: http://www.te-

tjanster.fi/te/sv/arbetsgivare/foretagare/blivande_foretagare/utbilda_dig_till_foretagare/index.html Hämtad 2016-10-20.

${ }^{186}$ NAV. Tiltak för å komme i jobb. Tillgänglig:

https://www.nav.no/no/Person/Arbeid/Oppfolging+og+tiltak+for+a+komme+i+jobb/Tiltak+for+a+komme+i+jobb Hämtad 2016-07-21.
} 
I flera av de nordiska länderna erbjuds även deltagande i reguljär utbildning som en arbetsmarknadsinsats. I Danmark kan arbetslösa ta del av i stort sett hela utbildningssystemet som del av en arbetsmarknadsåtgärd med vissa begränsningar gällande omfattningen. Detta beror både på den arbetslöses utbildningsnivå och om denne är försäkrad eller oförsäkrad. I Finland finns det en möjlighet att söka in till en utbildning via det normala antagningssystemet och sedan med AN-byråns godkännande studera med stöd av arbetslöshetsförmånen. ${ }^{187}$

I Finland finns det dessutom ett system för yrkesinriktad arbetskraftsutbildning, inom vilket den arbetslösa kan avlägga grund-, yrkes- eller specialyrkesexamen eller en del av examen. Ramverket tillåter dessutom i vissa fall personer som avbrutit sina högskolestudier att avsluta sina studier under en period upp till högst 24 månader. ${ }^{188}$

Efter finanskrisen tog den isländska staten initiativ till ett antal aktiveringsprogram som inkluderade utbildningsinsatser. De arbetslösa fick då välja mellan gymnasiestudier, förberedelseprogram för universitetsstudier, universitetsstudier eller vuxenutbildning. Därutöver kan arbetssökande, genom att ingå ett studiekontrakt med Arbetsförmedlingen, välja sina egna studier, som måste godkännas utifrån villkoret att de är relevanta för det fortsatta arbetssökandet. Den arbetssökande kan då få studiestöd för att täcka upp till 50 procent av kursavgiften.

I Norge kan personer med nedsatt arbetsförmåga delta i ordinarie utbildning i upp till tre år som en arbetsmarknadsåtgärd. I Sverige däremot är utbudet av utbildningar begränsat till de arbetsmarknadsutbildningar som upphandlas av Arbetsförmedlingen. ${ }^{189}$

I de autonoma regionerna är bilden splittrad när det gäller arbetsmarknadsutbildning. På Färöarna bedriver ALS kurser i egen regi fokuserade på att öka anställningsbarheten. På Grönland använder man sig sedan 2006 av så kallade Piareersarfiitcentra (totalt 18 fördelade över Grönland) för att bedriva arbetsmarknadsutbildning. Dessa finansieras gemensamt av kommunerna och utbildningsdepartementet och har som huvudsakligt syfte att fungera som väglednings- och förberedelsecentra och trenden går mot fler yrkesinriktade utbildningar. ${ }^{190}$ På Åland genomförs arbetsmarknadsutbildningarna av Ålands arbetsmarknads- och studieservicemyndighet (Ams) och Utbildnings- och kulturavdelningen (UKA). Själva utbildningen kan antingen upp-

\footnotetext{
${ }^{187}$ Lag om offentlig arbetskrafts- och företagsservice 916/2012.

${ }^{188}$ AN-tjänster. Yrkesinriktad arbetskraftsutbildning. Tillgänglig: http://www.te-

tjanster.fi/te/sv/arbetssokande/yrkesval_och_utbildning/arbetskraftsutbildning/index.html Hämtad: 2016-10-20.

${ }^{189}$ Nordiska ministerrådet (2015). Arbetsmarknadsutbildning i Norden - studie om de nordiska systemen för arbetsmarknads-

utbildning för arbetslösa. 2015:31.

${ }^{190}$ Ibid.
} 
handlas externt eller genomföras hos en utbildningsarrangör (ofta Ålands yrkesgymnasium).

\section{Subventionerad anställning}

Subventionerade anställningar erbjuds arbetslösa i de nordiska länderna. I Norge och Sverige är dessa anställningsformer främst riktade till särskilda målgrupper som står långt från arbetsmarknaden. I Norge erbjuds olika åtgärdsplatser (tiltaksplasser) på den ordinarie arbetsmarknaden. Under 2015 hade strax under 61000 åtgärdsplatser budgeterats, varav cirka 48300 var öronmärkta för personer med nedsatt arbetsförmåga. ${ }^{191}$ Arbetspraktik syftar till att ge deltagaren stöd $\mathrm{i}$ att lära sig ett arbete, och kan även användas för att testa om en viss typ av arbete passar deltagaren. NAV täcker då kostnader för deltagarens personliga utgifter. NAV erbjuder även lönebidrag i begränsade perioder, främst till personer med allvarligt nedsatt arbetsförmåga. För personer med nedsatt arbetsförmåga finns även möjlighet att få en plats på en så kallad skyddad verksamhet, som är specialiserade på arbetsträning och praktik. ${ }^{192}$

Sverige tillämpar flera former av subventionerade anställningar. Ett sådant är instegsjobb riktade till nyanlända invandrare, och särskilt anställningsstöd för långtidsarbetslösa. Därutöver finns även rättighetsstyrda insatser för samma målgrupper, såsom nystartsjobb och stöd för yrkesintroduktionsanställningar. För personer med en funktionsnedsättning som medför nedsatt arbetsförmåga finns subventionerade anställningar genom exempelvis lönebidrag, skyddat arbete hos offentlig arbetsgivare, trygghetsanställning, och utvecklingsanställning. Samhall AB är ett statligt bolag som erbjuder anställningar åt personer med funktionsnedsättning som medför nedsatt arbetsförmåga. ${ }^{193}$

För arbetslösa i Danmark finns ett antal möjligheter till subventionerade anställningar. Genom verksamhetspraktik kan arbetssökande få möjlighet att träna upp sin arbetsförmåga under en period på upp till 13 veckor (som för vissa målgrupper kan förlängas upp till 26 veckor och eventuellt ytterligare efter en konkret individuell bedömning) och mottar ersättning motsvarande arbetslöshetsersättning. Anställning med lönetillskott innebär att arbetsgivaren får lönebidrag från jobbcentret som även administrerar anställningen. Genom fleksjob kan personer med nedsatt arbetsförmåga få arbete som minst ett par timmar per vecka, och mottar lön för den effektiva

\footnotetext{
${ }^{191}$ Arbeids- og sosialdepartementet. Arbeidsmarketstiltak. 23 september 2015. Tillgänglig: https://www.regjeringen.no/no/tema/arbeidsliv/arbeidsmarked-og-sysselsetting/innsikt/arbeidsmarkedstiltak/id86897/ Hämtad: 2016-07-21.

${ }^{192}$ Ibid.

${ }^{193}$ Kommittédirektiv 2014:15. Översyn av Arbetsförmedlingen.
} 
arbetstiden. Sedan det efter en reform 2013 blivit betydligt svårare att förtidspensioneras har antalet fleksjob ökat med cirka 7 procent. ${ }^{194}$

I Finland finns en form av subventionerad anställning, Arbetsprövning, genom vilken en person som vill byta bransch eller har varit arbetslös länge, kan testa ett yrke under högst 12 månader. ${ }^{195}$ Det finns även möjlighet för arbetsgivare att få lönebidrag, som utformas individuellt och blir mer omfattande ju längre en person varit arbetslös. För personer som vill starta företag finns även en så kallad startpeng som erbjuds under den tid det beräknas ta för att starta upp verksamheten, högst 18 månader.

På Island kan arbetsgivare anställa arbetssökande i upp till sex månader med subventionerade lönekostnader. Har personen varit arbetslös i mindre än 24 månader betalas endast 50 procent av den grundläggande arbetslöshetsersättningen. För personer som varit arbetslösa i mer än 24 månader kan uppemot 100 procent av arbetslöshetsersättningen betalas. Det har även funnits entreprenörskapsprogram där individer har kunnat få bidrag för att starta företag.

\section{Slutsatser}

Den aktiva arbetsmarknadspolitiken är en viktig del av de nordiska ländernas verktygslåda. Utformningen av denna politik skiljer sig dock på några viktiga punkter länderna emellan. I Finland, Norge och Sverige är utformningen hierarkisk och i grunden centraliserad med statlig finansiering och reglering. I Danmark och på Island är utformningen mer decentraliserad. Gemensamt är att fokus i den aktiva arbetsmarknadspolitiken ligger på utbildningsinsatser, ofta med praktisk inriktning, för att förbättra matchningen mellan arbetsgivare och arbetstagare. Satsningar på att matcha personer som står långt ifrån arbetsmarknaden med yrken i sektorer där det råder brist på arbetskraft är framför allt vanligt i Finland, Norge och Sverige, där stora statliga initiativ tagits. Den reguljära utbildningssektorn används också som ett instrument för att bedriva arbetsmarknadsutbildning i samtliga nordiska länder. I de autonoma regionerna existerar också arbetsförmedling och arbetsmarknadsutbildningar i viss utsträckning. Exempelvis har Grönland satsat hårt på yrkesinriktad utbildning de senaste tio åren. Åland å sin sida har i ljuset av relativt låg arbetslöshet de senaste åren inte haft något större behov av satsningar på sysselsättningsfrämjande åtgärder.

\footnotetext{
${ }^{194}$ Steensberg, Morten (2015). Stigning ifleksjob: Men laver flere bare det samme?. 18 september 2015. Tillgänglig: http://www.avisen.dk/stigning-i-fleksjob-men-laver-flere-bare-det-samme_344842.aspx Hämtad: 2016-07-21. ${ }^{195}$ AN-palvelut. Arbetsprövning - praxis och bestämmelser. Tillgänglig: http://www.tetjanster.fi/te/sv/specialsidor/praxis_och_bestammelser/index.html Hämtad: 2016-07-21.
} 
Subventionerade anställningar används också som ett viktigt verktyg i de nordiska ländernas aktiva arbetsmarknadspolitik. I Norge och Sverige ligger specifikt fokus för vissa anställningsformer för utsatta grupper som långtidsarbetslösa, nyanlända och ungdomar, medan övriga länder satsat på generella subventionerade anställningsformer. En mer djupgående diskussion om målgrupperna för den aktiva arbetsmarknadspolitiken följer nedan.

\section{Målgrupper för den aktiva arbetsmarknadspolitiken}

Den aktiva arbetsmarknadspolitiken är i de nordiska länderna i olika utsträckning särskilt riktad mot prioriterade målgrupper. De målgrupper som beskrivs nedan är de som de flesta av de nordiska länderna har särskilt utformade arbetsmarknadsåtgärder för. I vissa fall är personer i dessa målgrupper prioriterade för de ordinarie arbetsmarknadsåtgärderna, som i Norge där åtgärdsplatser i första hand tilldelas personer med nedsatt arbetsförmåga, långtidsarbetslösa, ungdomar, långtidsmottagare av socialbidrag samt invandrare från länder utanför EES-området. I andra fall finns särskilt utformade program eller åtgärder för de olika målgrupperna. I detta avsnitt beskrivs verktyg och styrning för den aktiva arbetsmarknadspolitiken när det gäller långtidsarbetslösa och ungdomar.

\section{Långtidsarbetslösa}

\section{Verktygslåda}

Långtidsarbetslösa är en heterogen grupp, som ofta överlappar med en eller flera av de grupper som beskrivs nedan. Därmed erbjuds en rad olika åtgärder till de personer som varit arbetslösa en längre tid.

Flera av de nordiska länderna erbjuder personer som varit arbetslösa en längre period olika typer av lönesubventioner. I Finland har arbetsgivare som anställer personer som varit arbetslösa i över två år rätt till löneförmåner på 50 procent av lönekostnaden i en period på högst 12 månader. I Norge kan långtidsarbetslösa tilldelas så kallade tiltaksplasser (åtgärdsplatser), som motsvarar subventionerade anställningar, även om dessa främst är riktade till personer med nedsatt arbetsförmåga. I Sverige finns en jobb- och utvecklingsgaranti för långtidsarbetslösa. Garantin riktar sig till dem som varit borta från arbetsmarknaden under en lång tid och är det arbetsmarknadspolitiska program som har flest deltagare. Inom ramen för garantin kan arbetssökande ta del av olika insatser så som exempelvis coachning, förberedande insatser, praktik, arbetsträning och förstärkt arbetsträning. Sedan den 1 februari 2016 har jobb- och 
utvecklingsgarantins tre på varandra följande faser med olika insatser ersatts av en mindre detaljreglerad och mer individanpassad garanti, detta för att ge bättre stöd till de som är långtidsarbetslösa. Sysselsättningsplatserna inom den tidigare sysselsättningsfasen avvecklas successivt och ska från och med den 1 februari 2018 vara helt avvecklad. Arbetsgivare som anställer långtidsarbetslösa har möjlighet att få lönesubventioner (se avsnitt 11.1.3).

Både i Danmark och på Island är de åtgärder som erbjuds långtidsarbetslösa mycket varierande. Då båda länderna har en decentraliserad styrning av arbetsmarknadsåtgärder är det i stor utsträckning upp till kommunerna vilka åtgärder de väljer att erbjuda.

I de autonoma regionerna finns delvis också riktade åtgärder till långtidsarbetslösa. På Grönland kan en person som till följd av lång arbetslöshet, nedsatt hälsa eller annan oförmåga att kunna utföra arbete, som en rehabiliteringsåtgärd få stöd av kommunen att börja arbeta. Detta kan till exempel ske genom arbetsträning, lärlingsjobb eller omskolning. Under denna rehabiliteringsprocess får deltagaren antingen överenskommen lön eller en rehabiliteringspenning på 70 procent av minimilönen för en outbildad arbetare. Grönlands självstyre kan ersätta upp till 50 procent av denna kostnad. Färöarna däremot har inga riktade åtgärder för långtidsarbetslösa, utan personer i denna grupp ingår som resten av arbetskraften i ALS-systemet (systemet för arbetslöshetsersättning) där stöd kan erhållas för maximalt 648 dagar under en treårsperiod. De som faller utanför denna gräns omfattas av de ordinarie sysselsättningsskapande åtgärder som Socialministeriet beslutar om. På Åland kan långtidsarbetslösa ta del av de anställningar som subventioneras med sysselsättningsstöd för arbetsgivare. En arbetsgivare kan då få ekonomisk ersättning för att anställa en långtidsarbetslös person.

\section{Styrning}

De nordiska länderna styr arbetsmarknadspolitiken för att få personer som varit arbetslösa en längre tid i arbete. I Danmark är det upp till kommunerna att välja vilka åtgärder de erbjuder långtidsarbetslösa, och undersökningar visar att detta varierar stort mellan kommunerna. Genom den ersättningsreform som trädde i kraft vid årsskiftet 2016 vill den danska regeringen styra kommunerna till att erbjuda tidiga insatser för långtidsarbetslösa. Detta görs genom att ersättningen trappas ner i takt med längden på arbetslöshetsperioden, vilket är avsett att ge kommunerna incitament att förhindra att långtidsarbetslösheten ökar.

För långtidsarbetslösa i Finland kan de lokala AN-byråerna tillsammans med kommunen ta fram en så kallad aktiveringsplan, utöver den sysselsättningsplan som tas fram för alla arbetslösa. Aktiveringsplanen är lagstadgad och utarbetas för en person som har fyllt 25 år och för vilken en sysselsättningsplan har utarbetats tidigare och 
- Som på grund av arbetslöshet har fått arbetsmarknadsstöd för minst 500 dagar

- som efter arbetslöshetsdagpenningsperioden på 500 dagar har fått arbetsmarknadsstöd för minst 180 dagar på grund av arbetslöshet

- vars huvudsakliga försörjning under de senaste 12 månaderna har grundat sig på utkomststöd som betalats på grund av arbetslöshet.

Enligt lagen om arbetsverksamhet $\mathrm{i}$ rehabiliteringssyfte ska en aktiveringsplan utarbetas som ett samarbete mellan AN-byrån, kommunen och klienten. Vid sidan om ANbyråns tjänster kan aktiveringsplanen också innehålla social-, hälso-, rehabiliteringsoch utbildningstjänster som förbättrar sysselsättningsmöjligheterna.

Den isländska arbetsförmedlingen har vid olika tillfällen lanserat kampanjer för att minska långtidsarbetslösheten. År 2010 kontaktade myndigheten samtliga som varit utan arbete i mer än 12 månader. Dessa individer bjöds in till möten med arbetsförmedlare där de tillsammans gick igenom vilka alternativ som är bäst lämpade, och uppmuntrade dem att delta i någon av de tillgängliga åtgärderna som erbjöds i samarbete med företag, utbildningsinstitut och organisationer. Ytterligare en kampanj lanserades 2012, som riktade sig till personer som var på väg att mista sin rätt till arbetslöshetsersättning, för att öka deras chanser att få jobb. Kampanjen var ett samarbete mellan staten, kommuner och de sociala parterna, och gav arbetsgivare möjlighet att anställa långtidsarbetslösa med lönesubventioner.

I Norge är långtidsarbetslösa en av de målgrupper, tillsammans med ungdomar, nyanlända och personer med nedsatt arbetsförmåga, som NAV har öronmärkt de så kallade tiltaksplasserna (åtgärdsplatserna). Öronmärkning av dessa tiltaksplasser är det främsta medlet för hur NAV styr prioriteringen av olika målgrupper som står utanför den norska arbetsmarknaden. I praktiken erbjuds personer ur dessa grupper en åtgärdsplats när de så önskar.

I Sverige styrs arbetsmarknadsåtgärder för långtidsarbetslösa genom den så kallade Jobb- och utvecklingsgarantin. Garantin innebär att personer som varit utan arbete en längre tid blir erbjudna en rad insatser, såsom vägledning, arbetspraktik, arbetsträning, arbetsmarknadsutbildning eller hjälp med att starta företag. Har personen efter 450 dagar, som det kan lämnas ersättning för, i garantin inte fått ett arbete finns möjlighet att ta del av förstärkt anställningsstöd, extratjänst, arbetsträning eller utbildning med aktivitetsstöd. ${ }^{196}$

\footnotetext{
${ }^{196}$ Arbetsförmedlingen. Har du varit arbetslös länge?. Tillgänglig: http://www.arbetsformedlingen.se/Forarbetssokande/Stod-och-service/Fa-extra-stod/Arbetslos-lange.html Hämtad: 2016-07-21.
} 


\section{Resultat}

Då den danska ersättningsreformen som styr mot tidiga insatser för långtidsarbetslösa nyligen trätt i kraft är det svårt att dra några slutsatser gällande resultaten av denna åtgärd, men som beskrivits ovan finns det en möjlighet att antalet långtidsarbetslösa kommer att minska ifall kommunernas incitament för att minska långtidsarbetslösheten ökar.

Den isländska kampanjen 2012 för att få långtidsarbetslösa i arbete var framgångsrik, då cirka 70 procent av deltagare efter insatsen inte längre var registrerade som arbetslösa. Av de anställningar som resulterade av kampanjen var 65 procent inom privat sektor, 30 procent inom offentlig sektor, och 5 procent i den ideella sektorn.

I Finland ålades den offentliga arbetsförmedlingen att satsa särskilt på den strukturella arbetslösheten. Enligt en revision av arbetsförmedlingens ställning och tyngdpunkter kunde Statens Revisionsverk konstatera att arbetskraftsbyråernas system för styrning av verksamheten har sporrat till att inrikta byråernas resurser på tjänster för arbetssökande som haft svårt att finna sysselsättning, vilket ledde till att de antalsmässigt största kundgrupperna hos arbetskraftsbyråerna fått minskad uppmärksamhet och fått söka arbete på egen hand. ${ }^{197}$

I Sverige har Arbetsförmedlingen försökt utvärdera Jobb- och utvecklingsgarantin men några säkra slutsatser om reformens effekter har inte kunnat dras då en tydlig kontrollgrupp inte kan identifieras. Självskattning av deltagarna visar att knappt hälften anser sig ha förbättrat sina möjligheter till att hitta arbete. ${ }^{198}$ Institutet för arbetsmarknads- och utbildningspolitisk utvärdering (IFAU) instämmer i att avsaknaden av kontrollgrupp gör att det inte går att dra slutsatser om reformens effekter. Däremot undersökte IFAU i en rapport från 2013 var deltagarna som lämnat programmet tog vägen. Undersökningen visar att ungefär hälften av deltagarna mellan 2007-2012 lämnade programmet för att börja på ett osubventionerat (28 procent) eller subventionerat (16 procent) arbete. Samtidigt visar undersökningen att av de som lämnade programmet, oavsett orsak, var dock över hälften (65 procent) inskrivna på Arbetsförmedlingen igen två år efter att de börjat programmet. Detta förklaras till viss del av att subventionerade anställningar kräver att individen är inskriven på Arbetsförmedlingen, och således har de aldrig lämnat Arbetsförmedlingen. ${ }^{199}$

\footnotetext{
197 Julkisen työnvälityksen asema ja painopisteet. Valtiontalouden tarkastusviraston toiminnantarkastuskertomus. $174 / 2008$. Helsinki 2008, s. 9-10.

${ }^{198}$ Arbetsförmedlingen (2012). Jobb- och utvecklingsgarantin- en uppföljning ur deltagarnas perspektiv, URA $2010: 2$.

${ }^{199}$ Institutet för arbetsmarknads- och utbildningspolitisk utvärdering (2013) Jobb- och utvecklingsgarantin - Vilka deltar, vad gör de och vart leder det? Rapport 2013:12, IFAU, Uppsala.
} 


\section{Ungdomar/NEETs ${ }^{200}$}

\section{Verktygslåda}

Det är vanligt att ungdomar i de nordiska länderna som står utan arbete erbjuds olika typer av utbildningsinsatser. I Norge kan det handla om deltagande i en AMO-kurs, som erbjuds som en del av så kallad upplärning. Detta är främst till för personer som bedöms sakna kvalifikationer för att komma in på arbetsmarknaden och har ingen övre eller nedre åldersgräns. NAV hjälper annars ungdomar med att hitta praktikplats eller förmedla tjänster som vägledning, ekonomiskt stöd, tillfällig bostad, individuell plan och kvalificeringsprogram (som omfattar uppföljning, jobb och utbildning).

I Danmark ligger ofta ansvaret på kommunerna att se till att stötta NEETs. Kommunens barn- och ungdomsavdelning erbjuder stöd med praktik för unga medan ungdomsutbildningsavdelningen sköter kom pletterande kurser och särskilda stödsystem inom ramen för det allmänna utbildningssystemet. Om dessa insatser inte anses vara tillräckliga blandas jobcentret in. Ungdomsutbildningsavdelningen har en skyldighet att tillhandahålla studievägledning för ungdomar över 18 år, och för utsatta unga kan barn- och ungdomsavdelning stötta denna insats.

I Sverige finns möjlighet för ungdomar som saknar grundläggande högskolebehörighet eller gymnasieexamen att ta del av studiemotiverande kurser i syfte att underlätta för deltagaren att påbörja eller återgå till reguljära studier. Därutöver finns för personer 20-24 år som saknar fullföljd gymnasieutbildning möjlighet att få stöd att påbörja eller återgå till studier med målsättningen att fullfölja en gymnasieutbildning genom ett så kallat utbildningskontrakt som sluts mellan den arbetssökande, Arbetsförmedlingen och hemkommunen. Kontraktet innehåller en plan för individens utbildning och eventuella andra aktiviteter och stöd. Inom ramen för ett utbildningskontrakt ska det vara möjligt att studera på heltid men det ska också vara möjligt att kombinera deltidsstudier med arbete eller praktik utifrån personens individuella förutsättningar.

På Island har Arbetsförmedlingen tillsammans med Röda Korset och kommunerna startat så kallade multicenter för unga som hoppat av skolan eller blivit av med arbetet, där syftet är att hjälpa dessa ungdomar att hitta rätt karriärväg. Det finns även särskilda seminarier och workshops i Arbetsförmedlingens regi för unga med syfte att stärka deras möjligheter att få arbete genom till exempel jobbsökarkurser och kurser med syfte att stärka självkänsla, initiativtagande och självständighet.

\footnotetext{
${ }^{200}$ NEET är en förkortning av begreppet "Young people not in education, employment or training" (sv. Unga som varken arbetar eller studerar).
} 
I Finland har långtidsarbetslösa under 25 år rätt till en aktiveringsplan som utarbetas i samarbete med AN-byrån och kommunen. Planens syfte är att förbättra den ungas förutsättningar att hitta arbete på den öppna arbetsmarknaden och att delta i utbildning. Aktiveringsplanen kan innehålla föreskrifter om arbetsverksamhet i rehabiliteringssyfte, målet med vilken är att förbättra personens livskompetens och skapa sysselsättningsförutsättningar. Verksamheten kan anordnas av kommunen själv eller av annan organisation inom den offentliga eller den ideella sektorn. ${ }^{201}$

I de autonoma regionerna skiljer det sig åt hur stort fokus man valt att lägga på riktade åtgärder till ungdomar. På Grönland är NEETs ett stort fokusområde i sysselsättningsstrategin, främst till följd av låg sysselsättningsgrad hos gruppen unga under 29 år, och så kallade Piareersarfiit-centra (totalt 18 fördelade över Grönland) har ansvar för insatserna gentemot NEETs. Främst ligger här fokus på yrkes- och språkutbildningar. Åland har låg ungdomsarbetslöshet och fokus ligger främst på att jobba med allmän vägledning samt riktade insatser i projektform. På Färöarna gäller samma som beskrevs för långtidsarbetslösa ovan: riktade åtgärder saknas.

\section{Styrning}

Både Finland och Sverige har garantier för unga arbetslösa som styr insatserna för målgruppen. I Finland innebär garantin att de lokala AN-byråerna efter tre månaders arbetslöshet måste erbjuda en sysselsättningsplan med åtgärder. Åtgärderna kan inkludera arbete, arbetsprövning, studieplats eller rehabilitering. På Åland har motsvarande ungdomsgaranti inte införlivats då man i praktiken redan lever upp till målsättningarna för garantin. För svenska ungdomar som varit inskrivna på Arbetsförmedlingen i tre månader finns den så kallade Jobbgarantin för ungdomar. I denna ingår hjälp med att söka jobb, coachning och praktik samt studie- och yrkesvägledning. ${ }^{202}$

Även NAV har en garanti som innebär att ungdomar under 20 år som står utan studieplats eller arbete är garanterade erbjudande om att delta i en arbetsmarknadsåtgärd som AMO-kurs. Det finns även en garanti som omfattar unga arbetslösa mellan 20-24 år och ger rätt till en individbaserad handlingsplan som utarbetas mellan den arbetssökande och en NAV-handledare. Garantin för ungdomar 20-29 år med nedsatt arbetsförmåga innebär att go procent av denna grupp ska ha en godkänd aktivitetsplan. På senare tid har NAV även initierat ett projekt, Ny GIV, där man jobbar med uppsökande verksamhet för att få ungdomar att aktivt delta i arbetsmarknadsåtgärder.

\footnotetext{
${ }^{201}$ Lag om arbetsverksamhet i rehabiliteringssyfte 189/2001.

${ }^{202}$ Arbetsförmedlingen, Är du under 25 år?. Tillgänglig: http://www.arbetsformedlingen.se/For-arbetssokande/Stod-ochservice/Fa-extra-stod/Ar-du-under-25-ar-.html Hämtad: 2016-07-21.
} 
På Island har insatserna mot ungdomar främst styrts genom tillfälliga kampanjer, såsom uppstartandet av de multi-center som beskrivits ovan. Efter finanskrisen har också ett flertal större projekt genomförts mellan regeringen, kommuner och arbetsmarknadens parter. Av dessa har till exempel projektet Nám er vinnandi vegur (Lärande är vägen till arbete) varit inriktat på unga under 25 år. Deltagarna studerade främst till bristyrken och erhöll ekonomiskt stöd med studieprestationskrav.

Resultat

I Norge har 26,4 procent av de som deltagit i AMO efter sex månader heltidsarbete (inte inräknat personer med nedsatt arbetsförmåga). Däremot menar Riksrevisjonen att åtgärderna för att få personer med nedsatt arbetsförmåga i arbete genom AMO inte fungerar som önskvärt. ${ }^{203}$ Det finns också studier som menar att AMO-kurser uppvisar sämre resultat för arbetsdeltagande än andra åtgärder. ${ }^{204} \mathrm{Några} \mathrm{tydliga} \mathrm{re-}$ sultat för öronmärkningen av åtgärdsplatser har dock inte kunnat identifieras.

I Sverige har inga utvärderingar ännu genomförts för satsningarna nystartsjobb (för gruppen unga under 25 år) eller traineejobb och det är ännu oklart vilka effekter dessa reformer haft.

På Island visade uppföljningen av projektet Nám er vinnandi vegur att 85 procent fortsatte studera eller fick ett jobb efter första terminen medan 15 procent fortsatte vara arbetslösa.

\section{Reflektioner}

Styrning mot de olika prioriterade målgrupperna skiljer sig åt mellan de nordiska länderna, men generellt sett är det samma målgrupper, de som beskrivits ovan, som är prioriterade i arbetsmarknadspolitiken då de ofta står långt från arbetsmarknaden. Styrningen följer till stor del den organisationsstruktur som präglar arbetsmarknadspolitiken. Både Danmark och Island är länder som har en relativt decentraliserad struktur. I Danmark illustreras detta av att det i vissa fall är upp till kommunerna vilka insatser man erbjuder, som är fallet med exempelvis långtidsarbetslösa. Däremot är den senaste ersättningsreformen som beskrivits ovan ett exempel på hur staten skapar incitament för kommunerna att prioritera en viss målgrupp. På Island har staten styrt arbetsmarknadspolitiken framförallt genom, ofta kortsiktiga, kampanjer som i och för sig har visat sig vara framgångsrika på så sätt att en majoritet av de som deltar

\footnotetext{
${ }^{203}$ Riksrevisjonen (2014). Riksrevisjonens undersøkelse av NAV:s arbeidsrettede oppfølging av personer med nedsatt arbeidsevne. Dokument 3:10 (2013-2014).

${ }^{204}$ Markussen, S. \& Røed, K. (2014). The impacts of vocational rehabilitation. IZA Discussion Paper No. 7892.
} 
i insatserna inte längre är arbetslösa. Samtidigt kan frågan ställas hur framgångsrika kampanjerna är i ett längre perspektiv, och om de utesluter vissa målgrupper.

I de övriga länderna är styrningen mer centraliserad. I Norge har staten styrt mot en rad prioriterade målgrupper, framförallt genom öronmärkta subventionerade åtgärdsplatser (tilltaksplasser), som fördelas i budgeten.

I Sverige präglas styrningen till stor del av garantier för särskilda målgrupper. Garantier finns både för långtidsarbetslösa och för unga arbetslösa. Vad gäller nyanlända finns även stora statliga satsningar framförallt i form av subventionerade anställningar. Arbetsförmedlingens egna utredning visar att det finns för många olika typer av subventionerade anställningsformer vilket försvårar för arbetsgivarna. Arbetsförmedlingen föreslog i februari 2016 att slå ihop samtliga subventionerade anställningar för att minska regelkrånglet för arbetsgivare. ${ }^{205}$

\section{Ersättningssystem (passiv arbetsmarknadspolitik)}

\section{Arbetslöshetsförsäkring}

Kraven för att få inkomstbaserad arbetslöshetsförsäkring skiljer sig åt mellan de nordiska länderna. Den tydligaste skiljelinjen går mellan Danmark, Finland och Sverige å ena sidan, och Norge och Island å andra sidan. De förstnämnda länderna har krav på medlemskap i en arbetslöshetskassa, a-kassa, som betalar ut ersättningen, något som brukar kallas Gent-systemet (eller Gent-modellen), medan Island och Norge inte ställer något sådant krav.

I Danmark, Finland och Sverige finns alltså system med a-kassor som betalar ut arbetslöshetsersättning baserat på tidigare inkomst till medlemmar. A-kassorna är ofta knutna till fackliga eller andra intresseorganisationer. Förutom kravet på medlemskap i a-kassan finns ytterligare ett antal kriterier som måste uppfyllas av den arbetslöse för att ha rätt till inkomstbaserad försäkring. I Danmark är kravet att man ska ha varit medlem i en a-kassa i minst ett år, samt att man ska ha arbetat ett visst antal timmar under de senaste tre åren. ${ }^{206}$ För att få ersättningen krävs även att vara registrerad som arbetssökande i det lokala jobbcentret från den första arbetslöshetsdagen, samt att stå till arbetsmarknadens förfogande. För att fortsätta ta emot ersätt-

\footnotetext{
${ }^{205}$ Nandorf, Tove. 2016. Arbetsförmedlingen: slå ihop lönestöden till ett. Dagens Nyheter. 22 februari.

${ }^{206} 1924$ timmar under de senaste tre åren för heltidsförsäkrade, 1258 timmar de senaste tre åren för deltidsförsäkrade, eller minst 52 veckors utövning av självständig förvärvsverksamhet de senaste tre åren.
} 
ningen ska den arbetssökande närvara vid regelbundna möten med både jobbcentret och a-kassan.

I Finland krävs medlemskap i en a-kassa i minst 26 veckor samt att ha förvärvsarbetat minst 26 veckor under de senaste 28 månaderna. Granskningsperioden på 28 månader kan förlängas med högst sju år av godtagbara skäl såsom sjukdom, heltidsstudier eller vård av barn. Veckoarbetstiden under arbetsveckorna måste ha varit minst 18 timmar och lönen i enlighet med kollektivavtal. Om kollektivavtal inte slutits, ska lönen ha varit minst 1173 EUR i månaden (2016). För att få inkomstbaserad ersättning måste den arbetssökande anmäla sig som arbetssökande omedelbart efter att ha blivit arbetslös och därefter fortsätta stå till arbetsmarknadens förfogande.

I Sverige är kravet för att få inkomstrelaterad ersättning, förutom tolv månaders medlemskap i en a-kassa, att uppfylla både ett grundvillkor och ett arbetsvillkor. Grundvillkoret innebär att den sökande ska vara arbetsför, vilket innebär att kunna och vilja ta ett arbete på minst tre timmar varje arbetsdag och i genomsnitt minst 17 timmar i veckan, anmäld som arbetslös och arbetssökande hos Arbetsförmedlingen, samt i övrigt stå till arbetsmarknadens förfogande. Kraven säkerställs genom att den som är arbetslös en gång i månaden meddelar vilka jobb hen sökt och vilka aktiviteter hen genomfört för att bryta arbetslösheten. Om en person som får eller ansöker om arbetslöshetsersättning inte lämnar in aktivitetsrapporten i tid meddelar Arbetsförmedlingen det till a-kassan. A-kassan utreder och beslutar sedan om det påverkar arbetslöshetsersättningen. Arbetsvillkoret innebär att den sökande ska ha arbetat under sex av de föregående tolv månaderna. ${ }^{207}$

För den som inte är medlem i någon a-kassa finns i Danmark, Finland och Sverige möjlighet till olika former av grundersättningar som inte är relaterade till inkomst. I Danmark finns dock ingen annan ersättning att få för oförsäkrade arbetslösa förutom den så kallade kontanthjälpen, motsvarande socialbidrag, som beskrivs nedan. I Finland och i Sverige finns däremot en så kallad grunddagpenning, eller grundförsäkring även för de som inte uppfyller medlemsvillkoret för A-kassa på 12 månader sammanhängande medlemskap. För att få tillgång till grunddagpenningen i Finland krävs att den arbetssökande uppfyller arbetsvillkoret, det vill säga har varit i arbete i minst sex månader under de senaste 24 månaderna. Grunddagpenningen betalas i högst 500 dagar, av Folkpensionsanstalten. I Finland finns även ett så kallat arbetsmarknadsstöd för arbetssökande som inte uppfyller arbetsvillkoret. Samma regel gäller på Åland, med skillnaden att AMS (Ålands arbetsmarknads- och studieservicemyndighet) utför

\footnotetext{
${ }^{207}$ Arbetsvillkoret innebär att du under 12-månadersperioden direkt före arbetslöshetens inträde måste ha förvärvsarbetat 6 kalendermånader med minst 80 timmars arbete i varje månad. Om du inte uppfyller detta, krävs det att du har arbetat minst 480 timmar under en sammanhängande period av 6 kalendermånader. Minst 50 timmars arbete i varje månad krävs.
} 
kontroll och administration som på riksnivå sköts av FPA. För att ha rätt till grundersättningen i Sverige krävs att man uppfyller både grund och arbetsvillkoret som beskrivits ovan. Om den arbetssökande inte är medlem i någon a-kassa betalas ersättningen ut av Alfa-kassan.

På Island och i Norge är arbetslöshetsersättningen till skillnad från de övriga nordiska länderna helt statligt finansierad och administrerad. På Island har alla löntagare och egenföretagare i åldern 18-70 år som är fast bosatta rätt till arbetslöshetsersättning, med kravet att den sökande ska ha arbetat minst 25 procent av heltid under tre av de senaste tolv månaderna. Därutöver ska den sökande vara arbetsför och beredd att ta arbete varsomhelst i landet. Ersättningen betalas ut och administreras av Arbetsmyndigheten. Arbetslöshetsersättningen är finansierad genom Tryggingagjald som arbetsgivaren är ansvarig för. Denna peng ligger under andra halvåret 2016 på 6,85 procent av den anställdes lön.

I Norge betalas arbetslöshetsersättningen, dagpengen, av NAV och finansieras av staten. Genom att vara medlem i den så kallade folketrygden, den nationella försäkringen, har alla rätt till arbetslöshetsersättning. Medlemskap är automatiskt för alla som är bosatta i Norge, och kostnaden för medlemskapet betalas in tillsammans med skatten. Huvudvillkoren för att få den så kallade dagpengen att den sökande bor $i$ Norge och har fått sin arbetstid reducerad med minst 50 procent samt att den tidigare lönen uppgått till minst 1,5 gånger grundbeloppet under det senaste året, eller 3 gånger grundbeloppet de senaste tre åren. Det krävs även att den sökande är registrerad som arbetssökande och var fjortonde dag skickar in en rapport om vilka arbeten som sökts och huruvida den sökande har utfört avlönat arbete under denna period.

På Grönland finns ingen reguljär försäkring utan det är arbetsmarknadsstödet, som infördes 2006, som fungerar som bidrag vid arbetslöshet. Detta är avhängigt på tre faktorer: i) uppnått 18 års ålder eller är försörjare, ii) är folkbokförd på Grönland och iii) under de senaste 13 veckorna varit anställd och arbetat minst 182 timmar. Samtliga som uppfyller dessa faktorer är berättigade till arbetsmarknadsstödet. Stödet är skattepliktigt och utgörs av go procent av minimilönen för outbildad arbetskraft.

På Färöarna betalar varje arbetsgivare och anställd mellan 16 och 67 år in 1,25 procent av utbetald eller mottagen lön till arbetslöshetsförsäkringssystemet. Detta är en obligatorisk avgift med ett tak för löntagare på 6500 DKK årligen. Vid arbetslöshet har du rätt till 75 procent av den standardinkomst som gäller för lågutbildad arbetskraft under de tolv månader innan du blev arbetslös och efter 253 dagar består stödet av 75 procent av din intjänade inkomst. Därutöver är den maximala ersättningen fastställd till 210000 DKK per år vilket innebär att den maximala månadsinkomsten vid arbetslöshet är 17500 DKK. Egenföretagare på Färöarna kan teckna enskild arbetslös- 
hetsförsäkring och det finns även ett speciellt system för dem som är anställda av fiskeindustrin på land.

\section{Sjukpenning}

Sjukpenning betalas ut till personer som på grund av sjukdom eller skada inte kan arbeta. Hur sjukpenningen finansieras skiljer sig åt mellan de nordiska länderna. I Danmark är det kommunerna, med stöd från staten under det första året, som står för sjukpenningen. På Island, i Finland och i Sverige är det den nationella socialförsäkringsmyndigheten som betalar ut sjukpenningen. På Island finns står även fackförbunden för en del av sjukpenningen. I Norge är det NAV som står för sjukpenningen. Av de nordiska länderna är det sedan 2014 Danmark som har de strängaste reglerna vad gäller hur länge någon kan få sjukpenning.

I Danmark utbetalas sjukpenningen av kommunerna, men under det första året står staten för en del av kostnaderna. De fyra första veckorna ersätter staten 100 procent av kommunernas utgifter, sedan trappas det ner under det första året vartefter kommunerna utbetalar sjukpenning på egen bekostnad. Sjukpenningsreformen 2014 innebar att sjukpenningsperioden förkortades från 52 till 22 veckor, vartefter den sjukanmälde bedöms utifrån sju förlängningsregler. Den som inte får sjukperioden förlängd övergår till ett så kallat jobbavklaringsförlopp som syftar till att hjälpa den sjukanmälde tillbaka in på arbetsmarknaden. För personer som är i jobbavklaringsförloppet får däremot arbetsgivaren endast ersättning från staten som motsvarar kontanthjälpen medan de måste fortsätta betala ut lön. För att ha rätt till ersättningen ska den sjukanmälde även delta i hänvisad behandling och rehabilitering samt närvara vid möten som den är kallad till.

I Finland är det Folkpensionsanstalten (FPA) som betalar ut sjukdagpenningen, som en del av den nationella sjukförsäkringen. För att kvalificera sig för sjukdagpenningen måste den sjukanmälde ha arbetat minst tre månader före sjukanmälan, alternativt varit arbetslös arbetssökande, heltidsstuderande, sabbatsledig eller alterneringsledig. Efter 300 dagar med sjukdagpenning kan den sjukanmälde få rätt till sjukpension (i form av folkpension) eller invalidpension (i form av arbetspension). ${ }^{208}$

På Island betalas sjukpenning ut av den nationella sjukförsäkringen (Sjukratryggingar Islands), som lyder under välfärdsministeriet. För att få rätt till sjukpenning på Island krävs att den sjukanmälde är sjukförsäkrad, vilket alla som arbetat på Island i mer än sex månader automatiskt blir. Därutöver krävs att den sjukanmälde har varit

\footnotetext{
${ }^{208}$ Folkpensionsanstalten. Nedsatt arbetsförmåga. Tillgänglig: http://www.kela.fi/web/sv/nedsatt-arbetsformaga Hämtad: 2016-07-21.
} 
oförmögen att arbeta minst 21 dagar i följd, och att detta styrks av en läkare. Den sjukpenning som betalas ut av sjukförsäkringen täcker dock inte minimikraven för uppehälle, men de flesta fackförbund betalar ut extra ersättningar till medlemmar vid sjukdom eller skada. Samtliga arbetsgivare är enligt lag bundna till att betala premier som motsvarar en viss andel av de anställdas lön, till respektive fackförbunds sjukersättningsfond enligt gällande kollektivavtal. Detta innebär alltså att hur mycket ersättning, och hur länge man har rätt till sjukpenningen, beror på den enskildes kollektivavtal och kan därför variera mellan offentlig och privat sektor, där anställda inom offentlig sektor har betydligt bättre villkor.

I Norge är det NAV som utbetalar sjukpenningen efter de första 16 dagarna (som arbetsgivaren står för). För att ha rätt till sjukpenningen krävs medlemskap i folketrygden, den offentliga socialförsäkringen. Medlemskap är automatiskt för alla som är bosatta i Norge, och avgiften för medlemskapet betalas in tillsammans med skatten. Därutöver krävs att den sjukanmälde arbetat under de fyra veckor som föregått sjukskrivningen samt att inkomsten motsvarar minst 50 procent av grundbeloppet i folketrygden. Det finns även ett aktivitetskrav som innebär att den sjukanmälde tillsammans med arbetsgivaren ska upprätta en uppföljningsplan för hur den enskilde kommer tillbaka till arbetet, som även NAV tar del av.

Den svenska sjukpenningen betalas ut av den nationella Försäkringskassan till personer som inte kan söka eller ta ett arbete på grund av sjukdom. Kraven är att man måste vara sjuk minst en fjärdedel av tiden man skulle sökt arbete, att man är anmäld som arbetssökande givet att man slutade arbeta för mer än tre månader sedan och att man är försäkrad i Sverige. Ersättningen är 80 procent av den tidigare lönen (sjukpenningsgrundande inkomsten), eller maximalt 543 SEK per dag, de första 365 dagarna och därefter cirka 75 procent av den tidigare lönen. För att få ta del av sjukpenningen måste man ha sammanlagda inkomster på minst 10700 SEK per år. ${ }^{209}$ Från och med den månad man fyller 65 år har man endast rätt till sjukpenning om man skulle ha arbetat de dagar man är sjuk.

På Färöarna skiljer sig inte bilden väsentligt från den danska, men man har egna nivåer baserat på olika kriterier. På Åland gäller samma regler som i Finland och på Grönland aktiveras ett slags socialbidrag då en person inte klarar av att arbeta. Detta beskrivs vidare i avsnittet nedan. Däremot har många löntagare på Grönland enligt kollektivavtalen rätt till full lön vid sjukdom.

\footnotetext{
${ }^{209}$ Försäkringskassan, Sjukpenning för arbetssökande. Tillgänglig:

https://www.forsakringskassan.se/privatpers/sjuk/arbetssokande/sjukpenning Hämtad: 2016-07-21.
} 


\section{Ekonomiskt bistånd/Socialbidrag}

Ekonomiskt bistånd är i regel en ersättning som ska fungera som sista utväg för den som inte kan försörja sig. Gemensamt för samtliga länder är att kommunerna finansierar bidraget, med undantag för Danmark där staten står för en del av finansieringen. Vidare ställs det $\mathrm{i}$ varierande grad krav på mottagaren av ekonomiskt bistånd att delta i arbetsmarknadsåtgärder eller att stå till arbetsmarknadens förfogande.

I Danmark är socialbidrag, eller kontanthjälp som det kallas, relevant för personer på arbetsmarknaden som inte är medlemmar av en a-kassa och därmed inte har rätt till arbetslöshetsersättning, eller av andra skäl inte kvalificerar sig. Alla kan söka kontanthjälp men villkoret är att man på grund av sjukdom eller av andra skäl (såsom arbetslöshet) inte kan försörja sig eller sin familj, och att behovet inte kan täckas av andra ersättningar. Mottagaren av kontanthjälpen eller dennes partner får heller inte ha tillgångar på över 10000 DKK. Därutöver krävs att man står till arbetsmarknadens förfogande. Jobbcentren administrerar kontanthjälpen, och ser även till att villkoren uppfylls. Det är kommunerna som finansierar bidraget med hjälp av staten som står för 30 procent. I januari 2016 trädde nya regler i kraft som innebär att ersättningen trappas ner under det första året, från 80 procent av lönen de första fyra veckorna stegvis ner till 20 procent av lönen efter 52 veckor.

Socialbidrag kan i Finland vara relevant för både arbetslösa och anställda för att täcka nödvändiga utgifter när inte lönen, arbetslöshetsersättningen eller sjukpenningen räcker till. Det är däremot ovanligt att arbetslösa har socialbidrag som enda inkomst, då de som bedöms vara arbetsföra måste registrera sig hos arbetsförmedlingen och därmed kvalificerar sig för den nationella arbetslöshetsersättningen. Om en person som mottar socialbidrag vägrar att ta emot ett jobb eller att delta i aktiveringsinsatser, kan bidraget sänkas med upp till 20 procent. Socialbidraget finansieras och administreras $i$ Finland lokalt av kommunerna. Detta kommer dock att flyttas till Folkpensionsanstalten från januari 2017, då kostnaderna kommer att delas mellan kommunerna och staten.

På Island är bidragssystemet tudelat och består dels av de statligt administrerade bidragen för personer i specifika situationer (exempelvis pension, sjukpenning och arbetslöshetsersättning), dels av det grundläggande socialbidraget som administreras och finansieras på lokal nivå. Detta grundläggande socialbidrag är relevant för personer som uttömt alla andra möjligheter att få en inkomst. Man måste också visa att man aktivt söker arbete. ${ }^{210}$ Det är de lokala myndigheterna som beslutar om socialbidraget, men utifrån riktlinjer som satts av Välfärdsministeriet (Velferðarráđuneytið).

\footnotetext{
${ }^{210}$ Europeiska kommissionen, Your social security rights in Iceland. Tillgänglig: http://ec.europa.eu/employment_social/empl_portal/SSRinEU/Your\%20social\%2osecurity\%2orights\%2oin\%2olceland_en pdf Hämtad: 2016-07-21.
} 
I Norge finns socialbidrag för den som inte kan försörja sig själv på arbetsmarknaden och som inte har en egen förmögenhet eller mottar andra bidrag. Även här finansieras bidraget av kommunerna och betalas ut av de lokala NAV-kontoren. Vilka krav som ställs på mottagaren av socialbidrag varierar från kommun till kommun; lagen säger att kommunerna kan ställa krav på att mottagaren ska utföra vissa arbetsuppgifter eller inte tacka nej till jobberbjudanden.

I Sverige finns ekonomiskt bistånd som bygger på en individuell behovsbedömning, som görs av kommunernas socialnämnd. Biståndet ska utformas så att det stärker den enskildes möjligheter att leva ett självständigt liv. Regeringen har understrukit behovet av att socialtjänsten samverkar med framför allt Arbetsförmedlingen för att gemensamt samordna insatser som kan vara nödvändiga för att enskilda som av olika anledningar är i behov av ekonomiskt bistånd ska stödjas för att bli självförsörjande. En majoritet av kommunerna ställer i princip krav på att en arbetssökande måste vara anmäld hos Arbetsförmedlingen samt vara beredd att ta alla arbeten som denne kan utföra i första hand på heltid för att få försörjningsstöd. Detta krav på att stå till arbetsmarknadens förfogande har förtydligats genom en ny bestämmelse i socialtjänstlagen (infördes 1 juli 2016). Cirka 50 procent av de som får försörjningsstöd har arbetslöshet som primär orsak till behov av försörjningsstöd. ${ }^{211}$ Enligt socialtjänstlagen får kommunerna ställa krav på att den som får ekonomiskt bistånd ska delta i arbetsmarknadspolitiska program, delta i anvisad praktik eller kompetenshöjande verksamhet om den enskilde inte kunnat erbjudas en lämplig arbetsmarknadsåtgärd. ${ }^{212}$ Innan sådana åtgärder beslutas ska socialtjänsten samråda med Arbetsförmedlingen.

En majoritet av kommunerna har sedan lång tid inrättat egenfinansierade arbetsmarknadsinsatser till personer med ekonomiskt bistånd som i många fall tillhandahåller liknande insatser som Arbetsförmedlingen erbjuder, t.ex. matchning och coachning. ${ }^{213}$

För de autonoma regionerna har man på Grönland och Färöarna egna system för socialbidrag, medan man på Åland tillämpar samma regler som Finland. På Grönland beslutar kommunen om rätt till ekonomisk hjälp i händelse av att personen i fråga

- är arbetslös och inte har ett rimligt erbjudande om arbete och aktivt söker arbete

- bedöms vara oförmögen att arbeta på grund av anpassningsproblem eller ohälsa

- är sjuk eller mammaledig och därför inte är tillgänglig för arbetsmarknaden.

\footnotetext{
${ }^{211}$ Intervjuer med Vivi Jacobson-Libietis och Katarina Thorén.

${ }^{212}$ SOU 2015:44.

${ }^{213}$ Intervju med Vivi Jacobson-Libietis.
} 
Offentligt stöd får i allmänhet inte överstiga 65 procent av minimilönen för outbildad arbetskraft genom överenskommelse mellan SIK och regeringen.

På Färöarna aktiveras socialbidraget när arbetslöshetsersättningen (ALS) inte gäller. Detta socialbidrag har stora likheter med den danska kontanthjälpen.

\section{Andra ersättningar}

I flera av de nordiska länderna finns utöver de ersättningar som beskrivits ovan ytterligare bidrag för olika målgrupper. I Danmark, Finland och på Island finns olika former av ersättning för personer som genomgår rehabilitering på grund av nedsatt arbetsförmåga.

I Danmark finns så kallade fleksjob för personer med nedsatt arbetsförmåga. Kommunen betalar då dagpeng till fleksjobaren medan arbetsgivaren endast betalar lön för den effektiva arbetstiden (det finns ingen lägre begränsning för arbetstiden). Kommunerna mottar ersättning från staten de 18 första månaderna av arbetslösheten på två tredjedelar. Därutöver finns möjlighet att få så kallad revalideringsydelse, rehabiliteringsersättning, vilket är en ersättning för personer med nedsatt arbetsförmåga medan de genomgår rehabilitering vilket kan innebära aktiviteter såsom arbetsprövning, utbildning, och så vidare. Ersättningen kan betalas ut i form av kontanthjälp eller i form av lönesubvention. Det är kommunerna som beslutar om fleksjob och rehabiliteringsersättning. Rehabiliteringsteam på kommunerna bedömer individers arbetsförmåga och har som mål att begränsa antalet förtidspensionärer, både genom rehabiliteringsersättning och fleksjob.

I Finland finns en särskild inkomstförsäkring, rehabiliteringsbidrag, för personer som deltar i rehabiliteringsinsatser. Bidraget kan sökas av personer mellan 16-67 år och som är hindrade att arbeta på grund av deltagande i rehabiliteringsåtgärd. Bidraget betalas ut av Folkpensionsanstalten.

På Island finns särskilda rehabiliteringsfonder som arbetsgivare betalar in premier till. Anställda har då rätt till arbetsrelaterad rehabilitering. Kravet för att få ta del av rehabiliteringsfonderna är att individen ska ha en sjukdom eller funktionsnedsättning som förhindrar fullt deltagande på arbetsmarknaden, och att de har som målsättning att komma tillbaka till arbetsmarknaden efter rehabiliteringen. Rehabiliteringsfonderna drivs som privata organisationer men kan drivas av exempelvis sociala parter i samarbete med lokala myndigheter, finansdepartementet och andra offentliga aktörer. 
På Färöarna går det även att få ALS-pengen kompletterad med en så kallad revalideringsydelse om ALS är låg eller man är ensamstående försörjare. I detta fall ställs motprestationskrav efter sex månader om personen i fråga anses vara tillgänglig för att arbeta; ett krav i form av arbetsträning. Ersättningen varierar från 2000 DKK netto, om man är under 25 år och fortfarande bor hemma, till 10200 DKK netto, om man är ensamstående försörjare. 


\section{Bilaga 2 Deltidsarbete och tidsbegränsade anställningar}

Deltidsarbete är en vanligt förkommande företeelse på många arbetsmarknader och har i många länder bidragit till att stärka kvinnors arbetskraftsdeltagande. Trots det positiva utfallet att fler kvinnor stärkt sin ställning på arbetsmarknaden tack vare deltidsarbete är det inte helt oproblematiskt då deltid inte bara påverkar löneutvecklingen för den deltidsarbetande men också pensionsutbetalningar senare i livet. Framför allt kan detta få betydelse i ett jämställdhetsperspektiv av arbetsmarknaden.

Figur 21: Deltidssysselsättning i procent av total sysselsättning

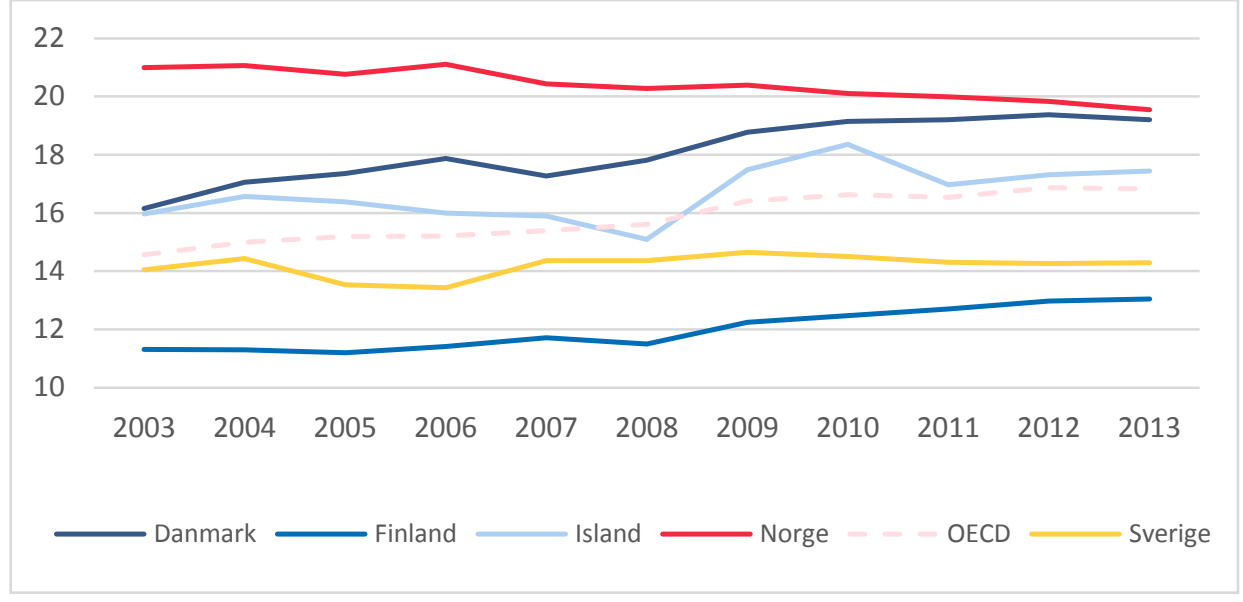

Kilde: OECD (2015) Part-time employment rate.

Förekomsten av deltidsarbete skiljer sig åt mellan de olika nordiska länderna. Figur 21 illustrerar andelen deltidsanställda av den totala sysselsättningen för de nordiska länderna samt OECD för det senaste decenniet. Norge har haft den högsta andelen deltidsarbetande det senaste decenniet, tätt följt av Danmark under de sista fyra åren. Omkring 20 procent av de sysselsatta i Norge arbetar deltid. Sverige och Finland har istället den lägsta andelen deltidssysselsatta med siffror kring 15 respektive 13 procent. Island, som ett undantag från resterande nordiska länder, såg en stigande trend i deltidssysselsättning när arbetslösheten kraftigt steg i efterdyningarna av finanskri- 
sen 2008. Då deltidsarbete generellt sett är mer förekommande bland kvinnor än bland män är det viktigt att se hur stor del av deltidssysselsättningen som utgörs av kvinnor i de nordiska länderna. Inte minst för att kunna avgöra om deltidsarbete potentiellt är ett problem eller inte.

Figur 22: Andel kvinnor av den totala deltidssysselsättningen

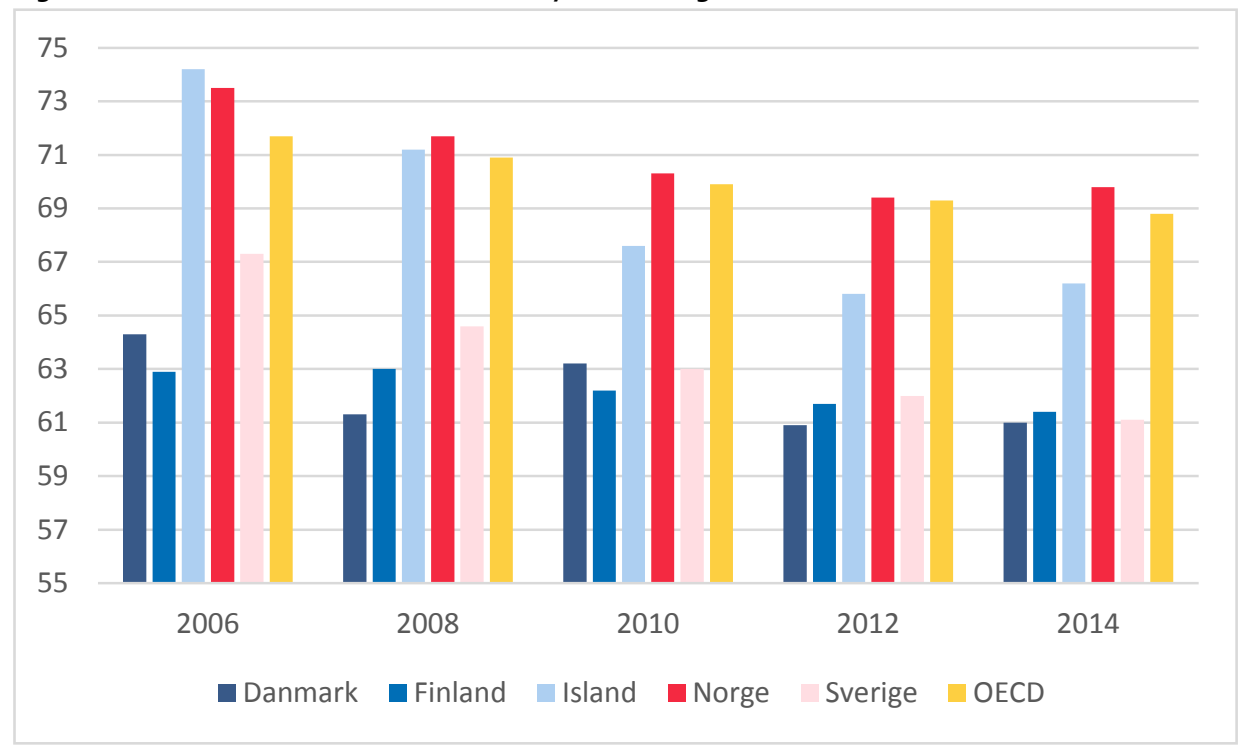

Kilde: OECD (2015) Incidence of full-time part-time (FTPT) employment - common definition.

Figur 22 illustrerar andelen kvinnor i deltidssysselsättning i relation till den totala sysselsättningen i de nordiska länderna samt snittet för OECD.

Att arbeta deltid är betydligt vanligare för kvinnor än män i alla de nordiska länderna samt OECD. Dock skiljer sig förekomsten något länderna emellan. Norge, som har den högsta andelen deltidsarbetande, hade 2014 också den största andelen kvinnor i deltidsarbete, snäppet högre än OECD samt Finland, där 70 procent av alla deltidsarbetande är kvinnor. Motsvarande siffror för Danmark, Finland och Sverige ligger på ca 60 procent. En förklarande faktor till varför kvinnor utgör en större del av den deltidsarbetande sysselsättning kan bland annat vara rätten till att gå ned i arbetstid $i$ samband med föräldraskap, vilket i större utsträckning fortfarande utnyttjas av kvinnor. Att kvinnor är överrepresenterade bland den deltidsarbetande sysselsättningen kan få konsekvenser ur ett jämställdhetsperspektiv på arbetsmarknaden med sämre löneutveckling och lägre pensionsutbetalningar. Skillnaden i hur deltidsarbete påverkar exempelvis pensionen kan också vara en förklarande orsak till de skillnader som finns i andel deltidsarbetande mellan de nordiska länderna. Enligt en tidigare studie 
från Nordiska Ministerrådet ${ }^{214}$ skiljer sig inverkan på en arbetstagares pension från deltidsarbete nämnvärt åt mellan de nordiska länderna. Enligt studiens resultat kan en arbetstagare i Norge eller Danmark arbeta deltid i tio år med 99 procent bibehållen pension medan en arbetstagare i Sverige eller Finland kan mista upp till sex procent av sin pension pga. samma omfattning av deltidsarbete. Detta kan vara en förklarande orsak till varför en betydligt större del av de sysselsatta i Norge och Danmark arbetar deltid i jämfört med Finland och Sverige.

Orsakerna till att arbeta deltid är inte enbart familjebildande faktorer utan de kan vara många. Några av de vanligare orsakerna för att arbeta deltid är exempelvis vård av barn eller nära anhörig eller pga. egen sjukdom, vilka båda är exempel på frivilligt deltidsarbete. Det har också blivit vanligare att arbeta deltid åren före och efter pensionsåldern. ${ }^{215}$ Många som arbetar deltid gör det dock ofrivilligt pga. brist på heltidsarbeten. Ofrivilligt deltidsarbete kan vittna om hur väl arbetsmarknaden kan utnyttja den kapacitet som finns på marknaden och utnyttja dess resurser optimalt. Andel ofrivilligt deltidsarbetande varierar mycket mellan de nordiska länderna, som illustreras i figur 23. Av alla som arbetar deltid uppger ca 5 procent i Norge att de vill jobba fler timmar medan över 30 procent av alla deltidsarbetande i Sverige uppger detsamma. Det är intressant att notera att Sverige som har den lägsta andelen deltidsarbetande av de nordiska länderna samtidigt uppvisar den högsta andelen ofrivilligt deltidsarbetande. Den höga andelen som vill jobba fler timmar än de i dagsläget gör vittnar om ett underutnyttjande av arbetskraften i Sverige. Samtidigt tyder det på att de som jobbar deltid i Norge gör det av frivilliga orsaker snarare än bristen på tillgängliga heltidsanställningar.

\footnotetext{
${ }^{214}$ Wennemo Lanninger och Sundström (2014) Part-time work in the Nordic region. Part-time work, gender and economic distribution in the Nordic countries. Nordiska Ministerrådet. TemaNord 2014:503.

${ }^{215}$ Dubois, Hans, Georgiana Runceanu och Robert Anderson (2016)," Extending working lives through flexible retirement schemes: Partial Retirement", Eurofound, Luxembourg: Publication Office of the European Union
} 
Figur 23: Ofrivillig deltid i procent av total deltidssysselsättning

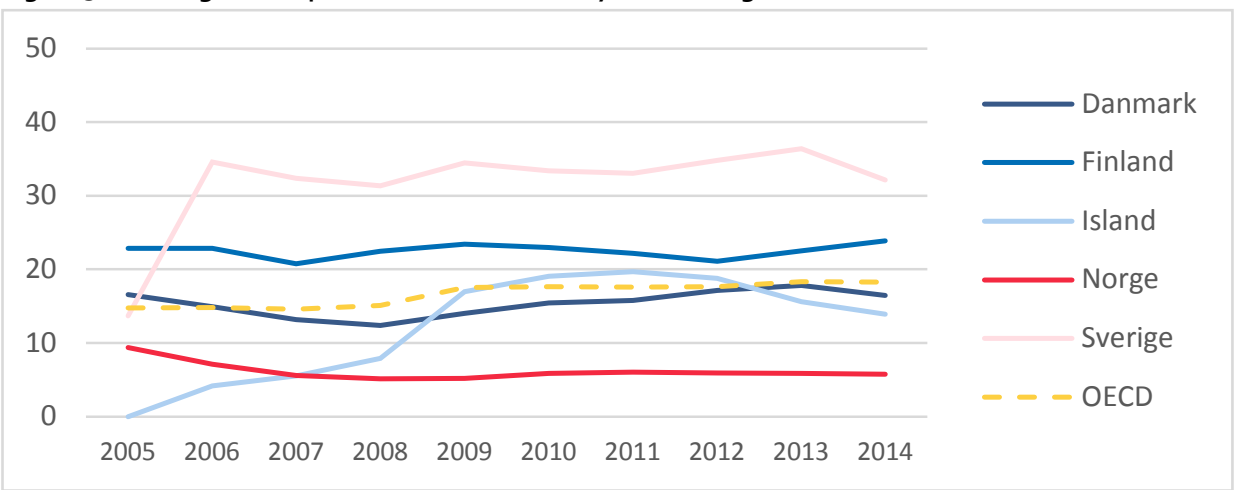

Kilde: OECD (2015) Incidence of involuntary part time workers.

Skillnaden i ofrivilligt deltidsarbete mellan män och kvinnor är relativt sett liten i de flesta av de nordiska länderna, vilket framgår i figur 24 som illustrerar ofrivillig deltidssysselsättning för kvinnor och män separat. Finland och Sverige utgör dock undantag $i$ skillnaden mellan män och kvinnor jämfört med resten av Norden. I Finland är det betydligt vanligare att kvinnor har ofrivillig deltid än män medan det omvända förhållandet gäller i Sverige. De svenska männens ofrivilliga deltidssysselsättning har som mest varit ca 20 procent högre än motsvarigheten i Finland och 35 procent högre än motsvarigheten i Norge. Sverige utgör ett tydligt undantag med den höga graden av ofrivillig deltidssysselsättning för män. 
Figur 24: Ofrivillig deltid uppdelad på kvinnor och män

Kvinnor med ofrivllig deltid

40

30

20

10

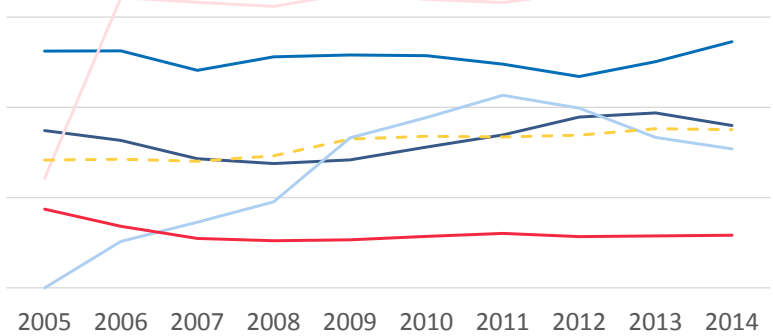

Män med ofrivillig deltid

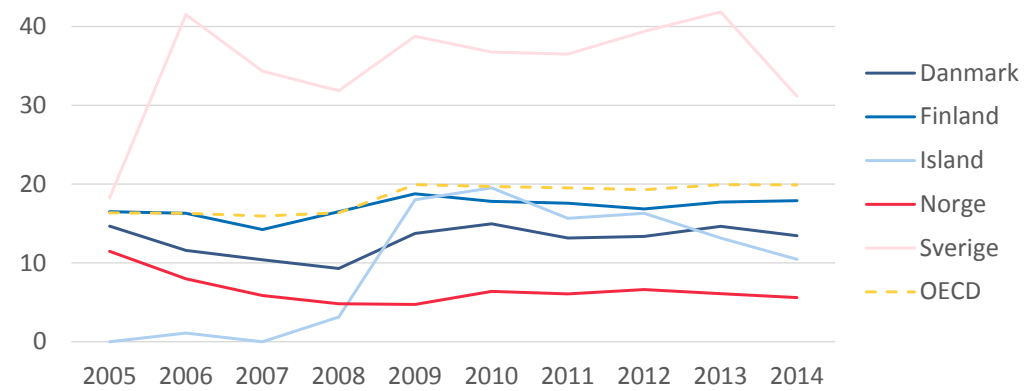

Kilde: OECD (2015) Incidence of involuntary part time workers.

Tidsbegränsade anställningar fyller ofta en betydande funktion i ungdomars etablering på arbetsmarknaden. Möjligheten till tidsbegränsade anställningar kan därför bidra till att hålla nere ungdomsarbetslösheten. Tidsbegränsade anställningar utgör också mindre riskfyllda anställningar för företag när konjunkturutvecklingen är oviss. Det är vanligt att andelen tidsbegränsade anställningar minskar vid en konjunkturnedgång då det är lättare för företag att låta den delen av personalstyrkan gå snarare än den delen som är tillsvidareanställd och där av skyddad av gällande lagar om anställning och anställningsskydd. Tidsbegränsade anställningar kan dock utgöra en osäkerhet för arbetstagaren. Det kan även finnas en risk för att arbetsgivare utnyttjar visstidskontrakt staplade på varandra för att komma runt gällande lagar om anställning och anställningsskydd. Figur 25 illustrerar andel tidsbegränsade anställningar av den totala lönearbetande sysselsättningen de nordiska länderna samt snittet i OECD under det senaste decenniet. 
Figur 25: Tidsbegränsade anställningar i procent av den lönearbetande sysselsättningen

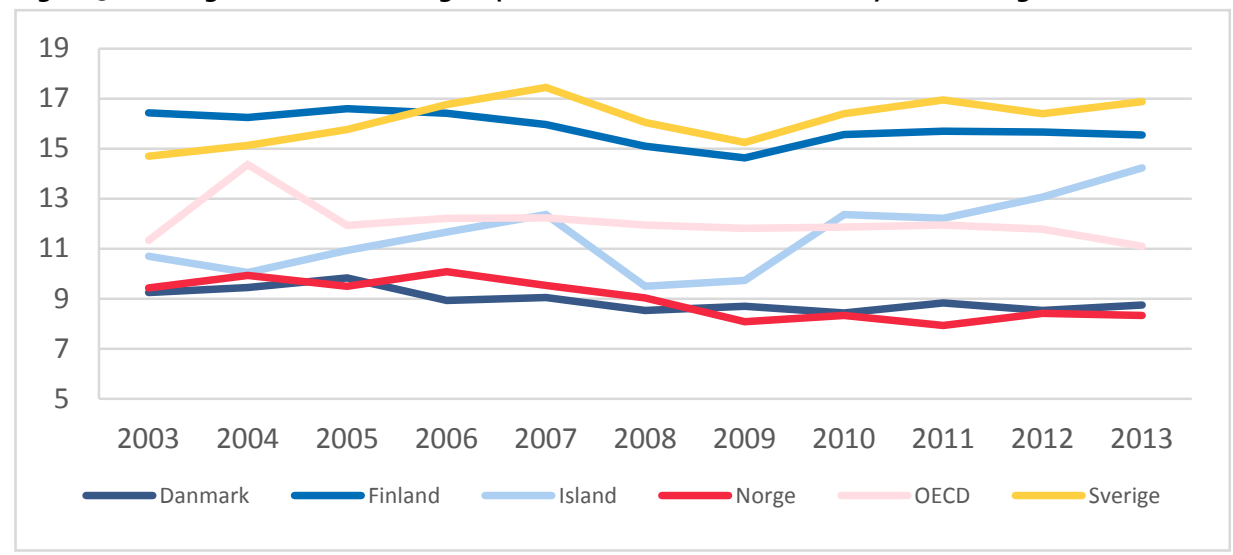

Kilde: OECD (2015) Temporary employment.

Tidsbegränsade anställningar är mest vanligt i Sverige och i Finland där över 15 procent av all lönearbetande sysselsättning utgörs av tidsbegränsade anställningar. Det är även främst i Finland och Sverige samt Island som andelen tidsbegränsade kontrakt minskade i och med konjunkturnedgången i samband med krisen. Detta kan vara ett tecken på hur dessa typer av anställningar används och utnyttjas på arbetsmarknaden.

Sverige är också det land som har minst strikt reglering av användandet av tidsbegränsade anställningar enligt OECDs index över arbetsmarknadsreglering som illustreras i figur 25. OECDs index mäter reglering av arbetsmarknaden på en sex-gradig skala där noll (o) innebär helt oreglerad och sex (6) innebär helt reglerad. Regleringen av användandet av de tidsbegränsade anställningarna kan vara en stor förklarande faktor till diskrepansen mellan de nordiska länderna som illustreras i figur 26. 


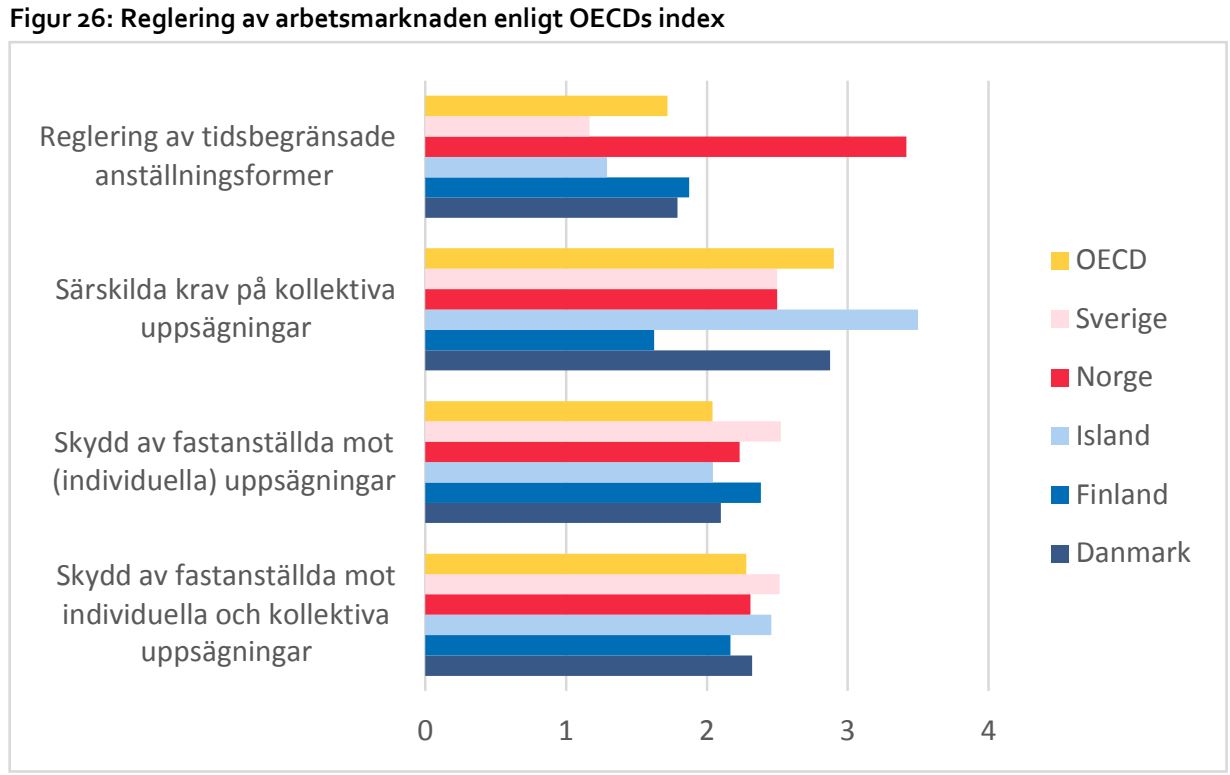

Kilde: OECD (2015) Strictness of employment protection.

Norge, som uppvisar den lägsta andelen av tidsbegränsade anställningar i Norden, är också det land med striktast reglering av användande av dessa typer av anställningar, även i förhållande till OECD.

För det kvarvarande aspekterna av OECDs index över reglering av arbetsmarknaden är de nordiska länderna samt OECD mycket samstämmiga. Bortsett från Norges striktare reglering av tidsbegränsande anställningsformer är det bara krav på kollektiva uppsägningar som skiljer länderna åt där både Island och Danmark har striktare reglering i det avseendet än resterande länder. 
Nordiska ministerrådet Ved Stranden 18

DK-1061 Copenhagen K

www.norden.org

\section{Styrning av arbetsmarknaden i Norden}

Internationellt talas det ofta om den nordiska

modellen - en modell som sammanlänkar de nordiska

länderna och dess välfärdssystem. Länderna har

dock valt att arrangera arbetsmarknadspolitiken

på olika sätt. Arbetsförmedling och andra typer av

arbetsmarknadsåtgärder görs på olika sätt av olika

aktörer i de olika länderna. Alla länder brottas dock med

samma utmaningar kring arbetslöshet och utanförskap.

Syftet med denna rapport från Oxford Research är att jämföra de olika system som finns för att styra arbetsmarknadspolitiken i Norden för att länderna därmed ska kunna lära sig av varandra.

Rapporten granskar de reformer som gjorts sedan 2000 för att utröna vad som fått effekt. Rapporten konkluderar med rekommendationer kring bland annat detaljstyrning, ekonomiska incitament som styrmedel, privata aktörer, reformtakten i Norden samt kommunernas roll inom arbetsmarknadspolitiken.

TemaNord 2016:556

ISBN 978-92-893-4763-1 (PRINT)

ISBN 978-92-893-4764-8 (PDF)

ISBN 978-92-893-4765-5 (EPUB)

ISSN 0908-6692

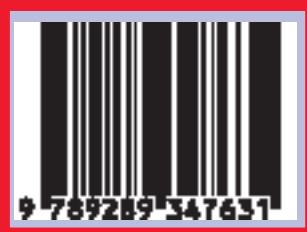

